\title{
Riches of the forest:
}

Fruits, remedies

and handicrafts

in Latin America

\section{Editors}

Citlalli López

Patricia Shanley

Alfredo Celso Fantini

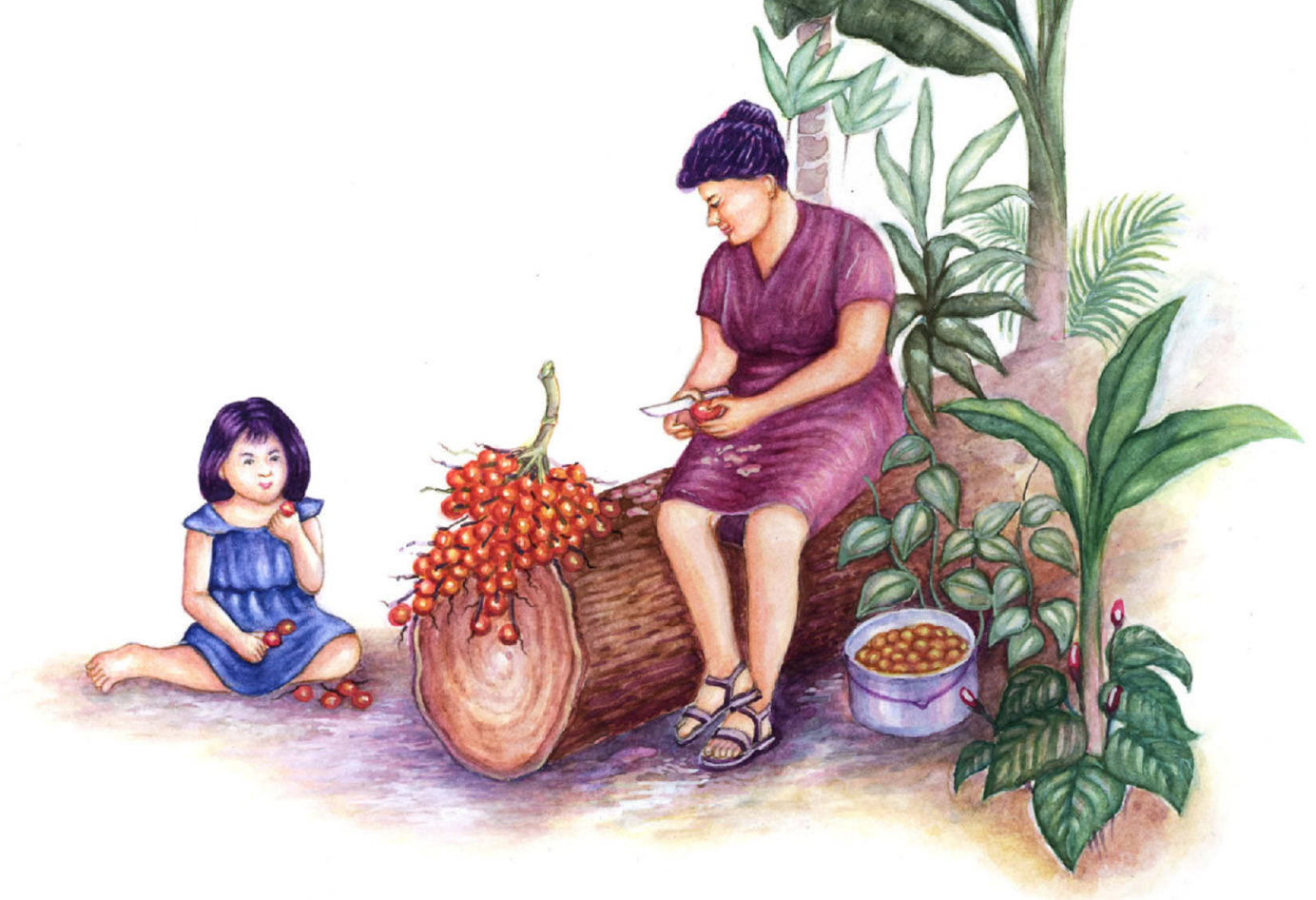




\section{Riches of the forest: \\ Fruits, remedies and handicrafts in Latin America}





\title{
Riches of the forest: Fruits, remedies and handicrafts in Latin America
}

\author{
Editors \\ Citlalli López \\ Patricia Shanley \\ Alfredo Celso Fantini
}
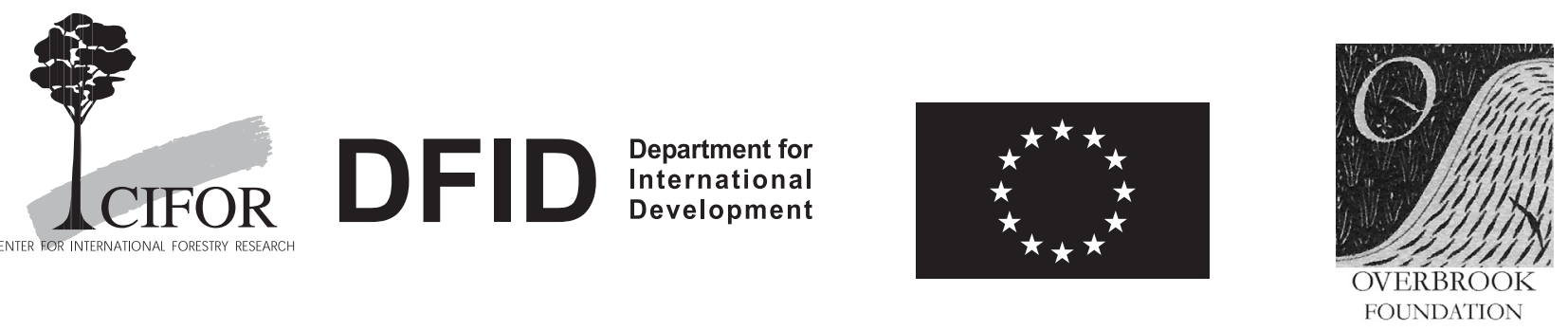
Scientific reviewer: Miguel N. Alexiades

Reviewer and copy editor: Tess Holderness, Claire Miller (assistant)

Copy editor of introduction and conclusions: Henning Pape-Santos

Case study and cover illustrations: April Mansyah

Botanical illustrations: Silvia Cordeiro

(except Sabal yapa and Pouteria sapota by Ishak Syamsudin)

Lay-out: Eko Prianto and Yani Saloh

(C) 2004 by Center for International Forestry Research

All rights reserved. Published in 2004

Printed in Desa Putra, Indonesia

ISBN 979-3361-46-8

Office address:

Jalan CIFOR, Situ Gede

Sindang Barang, Bogor Barat 16680, Indonesia

Mailing address:

P.O. Box 6596 JKPWB, Jakarta 10065, Indonesia

Tel: $+62(251) 622622$

Fax: $+62(251) 622100$

E-mail: cifor@cgiar.org

Website: www.cifor.cgiar.org 


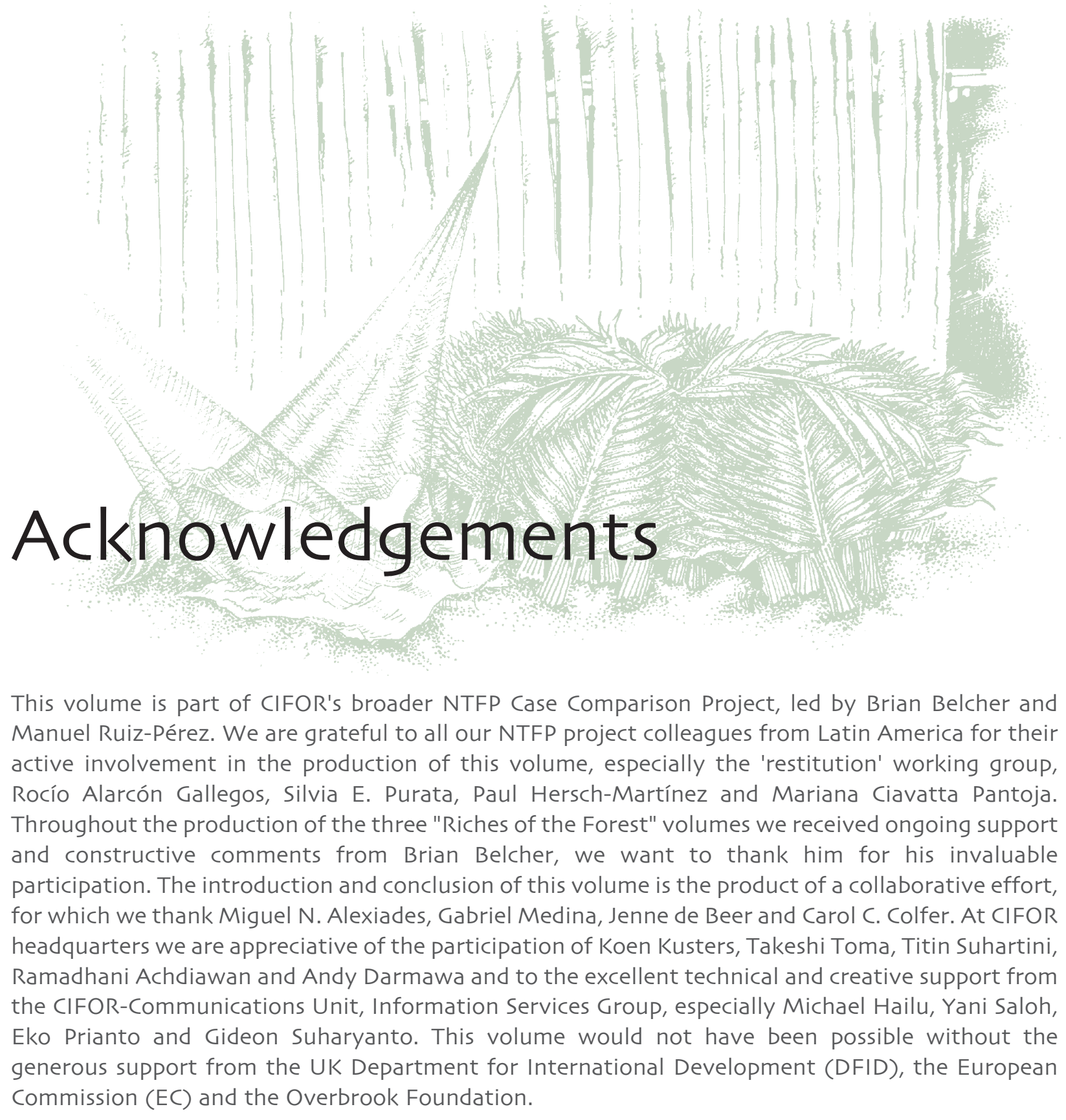




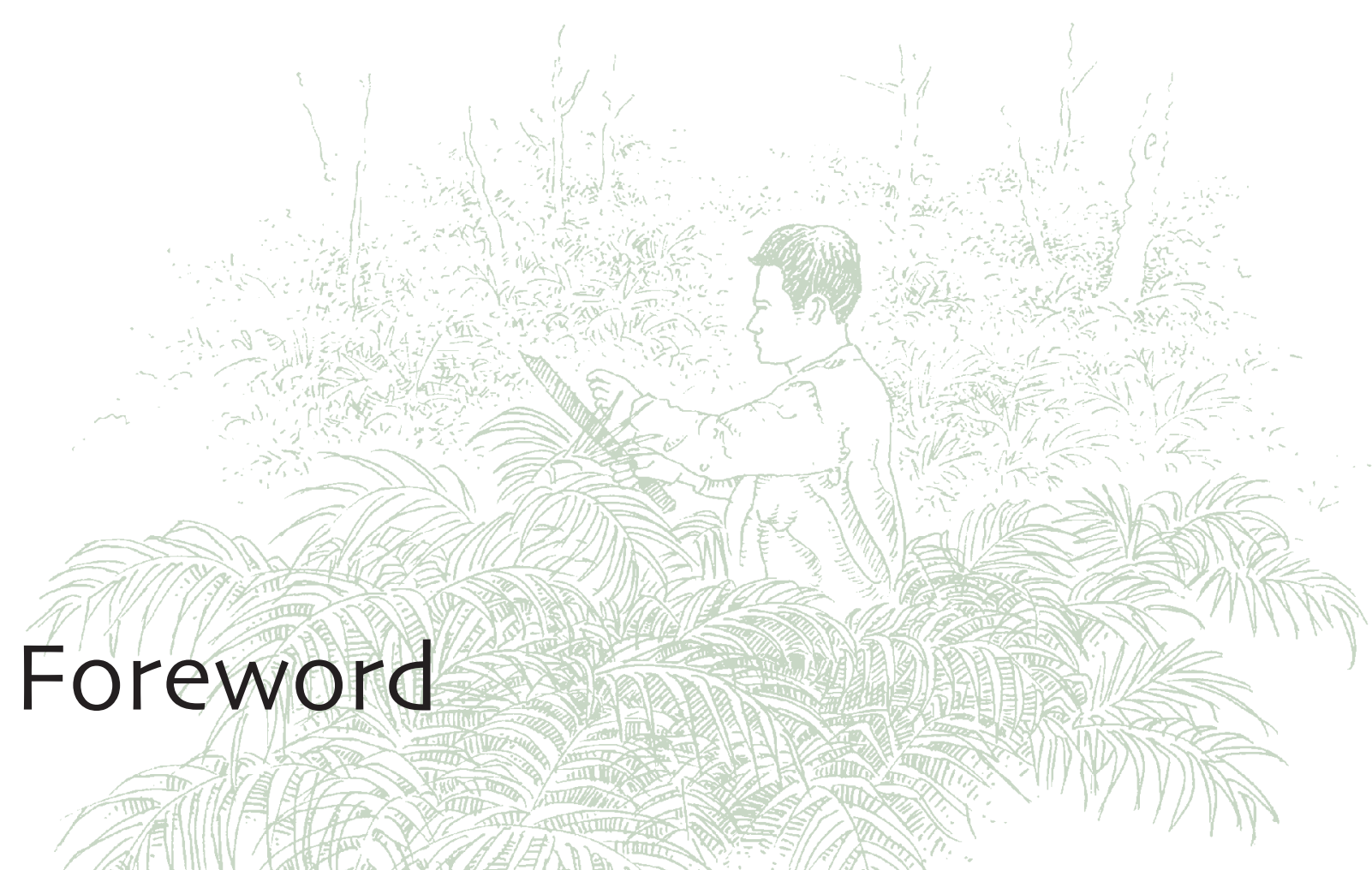

While humans have always depended on plants for their survival as well as for their physical, aesthetic and spiritual well-being, the links between people and plants have become increasingly vast and complex. Many plant products are still consumed and exchanged outside of the monetary system, close to the same forests where they are harvested or produced. Other products however, are transformed well beyond recognition and transported half-way across the world, generating millions of dollars in foreign exchange and creating considerable employment among harvesters, processors, traders and retailers. This trend in turn, reflects a fundamental historical process: the increasing interconnections - economic, social and cultural - that link disparate environments, people and places.

The chapters in this book tell one and many stories. Overall, the most important message is that Latin American forests contain an extraordinary diversity of plants which, over thousands of years, humans have learned to exploit, harness, manipulate, and in some cases promote, while in others sadly - destroy. This diversity continues to hold a promise for human social development, albeit one not without challenges. One of the many themes within this book relates to human ingenuity and adaptability. Non-timber forest products have historically served as safety nets for the farmers and extractors who harvest and sell them, and as such, are part of complex management systems and responses to environmental, political and economic fluctuations. 
International demand for Latin American forest products, for example, has historically undergone 'boom and bust' cycles. Booming demand has typically followed on from the 'discovery' of a forest product and its later integration into the world market. This in turn, has sometimes led to the product or plant's eventual demise, through over-exploitation or through substitution by a more abundant or cheaper alternative. Another theme contained within the narratives of this volume thus refers to the social, political and economic history of the Latin American tropics, as revealed through the stories about its forest plant products and the people who harvest and sell them. Yet another theme relates to the way the changing fortunes of different forest plants are linked to the changing fortunes of different groups of people. Any change, be it in terms of supply, demand, or any of their conditioning factors, is linked to shifts in equity between different stakeholders along the commodity chain.

Readers of this book can thus draw some important lessons - warnings as well as inspiration - from the plant products and the people portrayed within these pages, and from the anecdotes described in the individual case studies. Above all, they can admire and ponder the ways in which the lives and fates of a myriad of people, plants and places are linked together by forest products and by those who harvest, process, transport and consume them.

\section{Miguel N. Alexiades}

Department of Anthropology

University of Kent

Canterbury, U.K. 


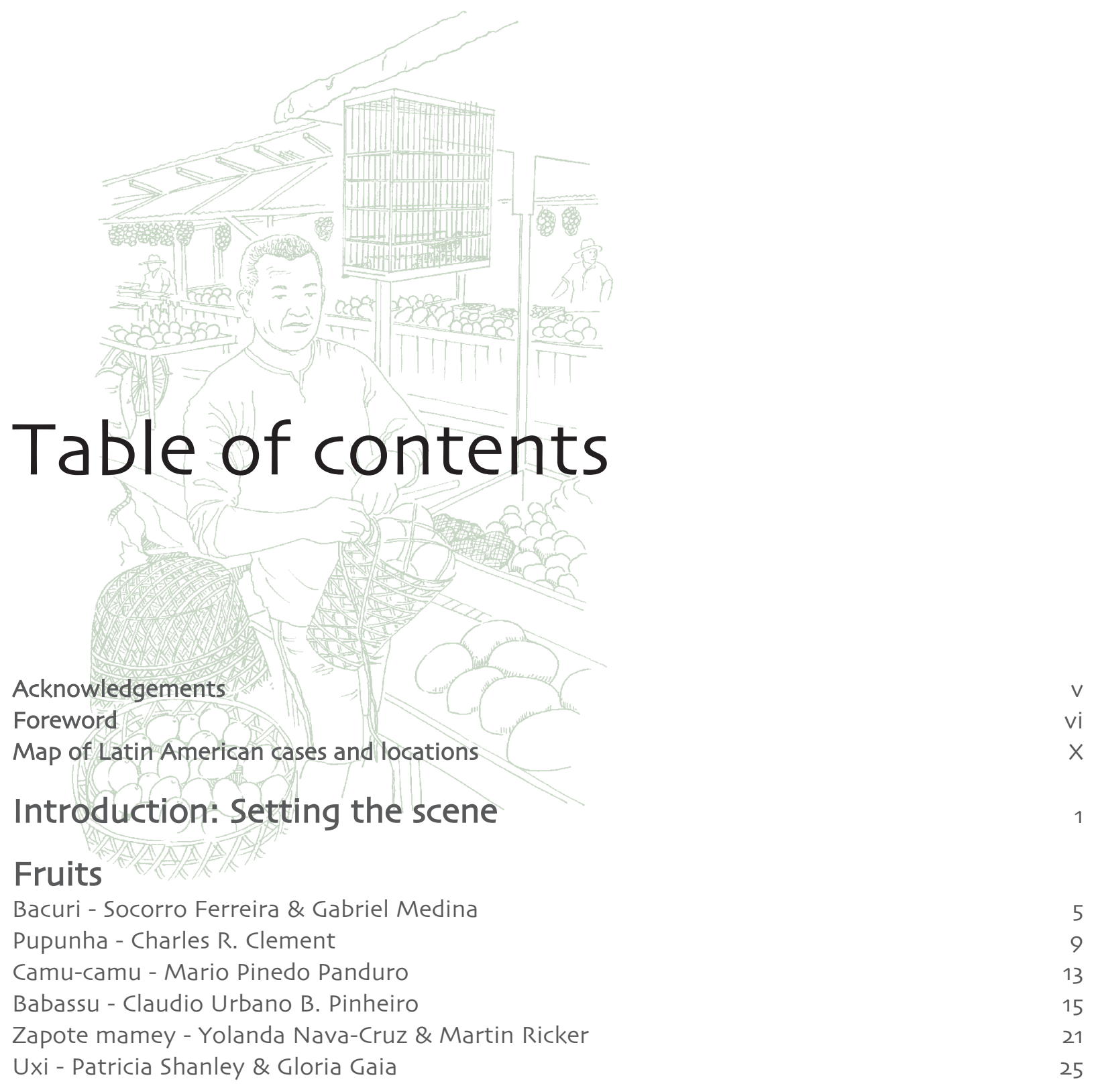




\section{Leaves}

Espinheira-santa, medicinal leaves - Marianne C. Scheffer

Camedor palm, ornamental plant / decorative leaves - César Carrillo Trueba 33

Toquilla fibre, Panama hat, - Rocío Alarcón Gallegos 37

Jipi japa fibre, handicrafts - Erik Arancibia \& Fausto López 41

Pita fibre, embroidery - Fabrice Edouard 45

Carqueja, medicinal leaves - Walter Steenbock 49

Xa'an palm, thatching leaves - Javier Caballero, María Teresa Pulido 53

\& Andrea Martinez-Ballesté

\section{Seeds, Roots and Shoots}

Allspice, pepper seasoning - Miguel Angel Martínez Alfaro,

Virginia Evangelista Oliva, Myrna Mendoza Cruz, Cristina Mapes

\& Francisco Basurto Peña

Fáfia, Brazilian ginseng - Cirino Corrêa Júnior \& Lin Chau Ming 61

Ipecacuana, medicinal root - Rafael A. Ocampo Sánchez 65

Palmito, edible palm heart - Alfredo Celso Fantini 69

Andiroba, medicinal oil - Patricia Shanley 73

\section{Bark and Wood}

Alebrijes, wood carvings - Silvia E. Purata, Berry J. Brosi \& Michael Chibnik 77

Cat's claw, medicinal vine - Wil de Jong \& Walter Nalvarte 81

Amate, bark paper - Citlalli López $\quad 85$

\section{Exudates}

Pine resin - Ynocente Betancourt Figueras \& Maria Josefa Villalba Fonte 89

Linaloe, wood carving / essential oil - Paul Hersch-Martínez 93

Rubber, vegetal leather - Mariana Ciavatta Pantoja 97

\section{Lessons learned:}

Cultural and commercial benefits of forest products 


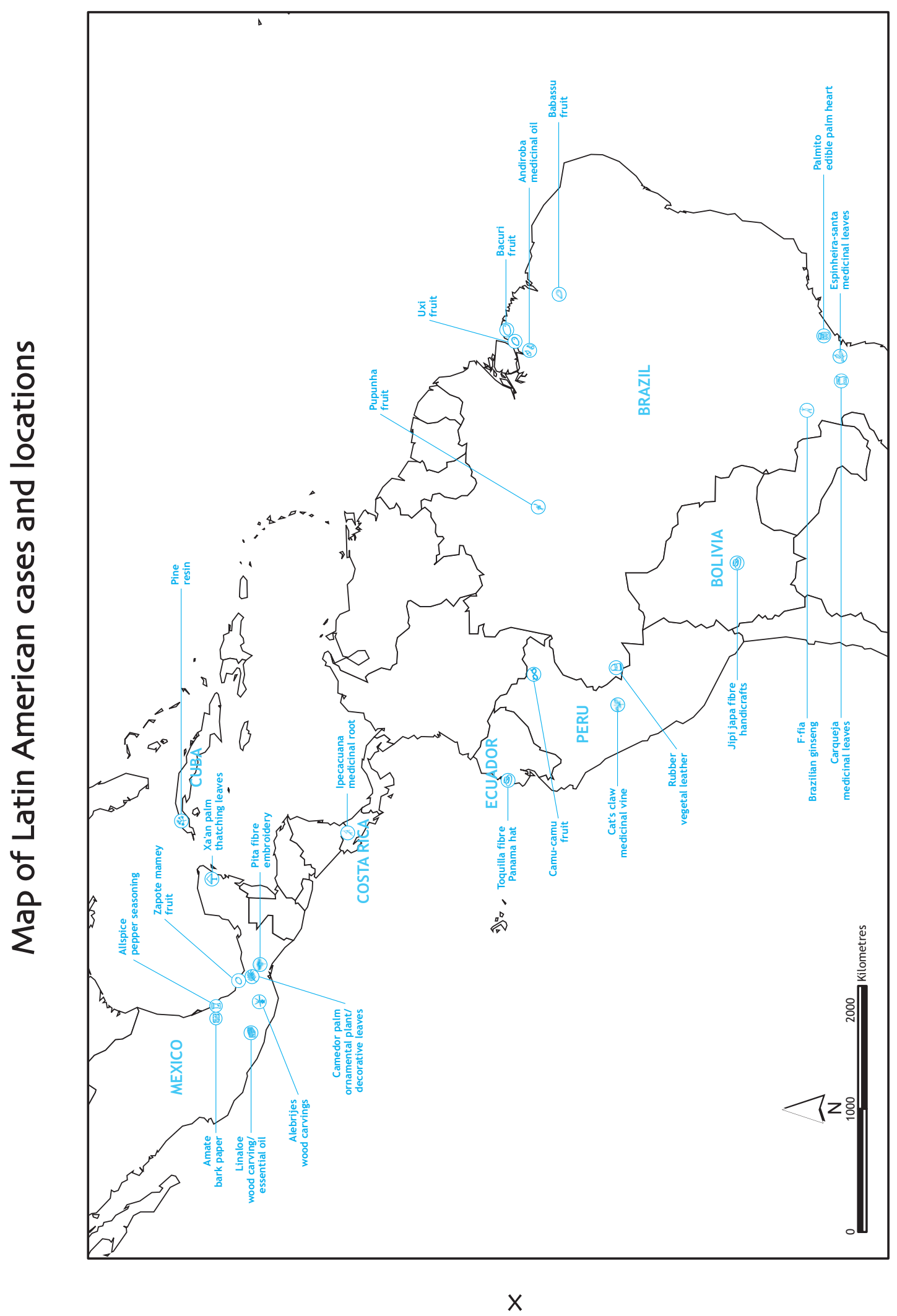




\section{Introduction: Setting the scene}

This book compiles traditional and specialized knowledge about 26 plants used by rural and urban people in Latin America. The pages tell real-life stories about a wide range of forest products and the people who use and manage them. Did you know, for example, that Panama hats are woven by artisan women in Ecuador? That linaloe oil now produced and exported by India was originally a Mexican industry? Or that a tall palm tree is cut down to extract the delicate, white 'heart' used to grace your salad?

What can we learn from the people who carve out a living harvesting these forest products? The individual chapters illustrate how different forest foods, fibres and medicines are grown, harvested, processed and traded. Through these stories we learn about the history of such products - some of which have been used and traded for centuries, while others are relatively new. We also find out about the various opportunities and problems that collectors and traders face, and the way they respond to change.

\section{Boom and Bust: Historical cycles of trade in forest goods}

In Latin America, the history of its inhabitants is intimately tied with the history of forest products. For centuries, intensive trade and cultural exchange has linked various regions of the Americas. In the pre-Columbian era, indigenous people exchanged goods such as mamey fruit, and amate bark 
paper. Between the sixteenth and nineteenth centuries European colonizers eradicated many of the trade networks and customs that linked people to their plants and land. Paradoxically, however, as local and regional networks were destroyed, global trade in Latin American tropical plants thrived. Vanilla, quinine, and ipecac medicinal roots were among the first products traded. Broad cultural interchange is evident today in the use and processing of various species. In Mexico, for example, linaloe wood, obtained from Bursera species, has been carved since pre-Hispanic times, but its decoration has come to incorporate a combination of Mexican, Spanish and Asian techniques.

During the industrial era, technical advances involving mechanisation, urbanisation and transportation allowed for more widespread trade in forest goods, with booms in product extraction occurring worldwide. Latin America became a source of globally valued rubber, ipecac roots, chicle latex, barbasco roots with natural pesticide properties and Panama hats. This explosion of interest was followed by the modern era 'bust' in international marketing of forest goods. The mid-twentieth century saw forests starting to be valued principally for their timber resources and for wood fibre for paper-making. At the same time, commercial and scientific interest in other forest products declined. Chemical and synthetic substitutes became more widespread: barbasco was replaced by DDT, chicle by synthetic chewing gum and natural fibres with plastics.

But in yet another turnaround, renewed interest in natural foods, crafts and medicines has recently arisen, a shift that fostered increased trade in a range of forest products. Of the cases described in this volume, many, such as cat's claw (a medicinal vine), camu-camu fruit, rubber for producing vegetal leather and Brazilian ginseng, have entered the world economy in only the last two decades (Alexiades and Shanley 2004).

The recent increase in consumer interest has been accompanied by attention from conservation and development agencies. Beginning in the 1980s, recognition of the rapid rate of deforestation and a newfound appreciation of the difficulties facing people living in rural areas led to a renewed focus on forest products other than timber. Researchers began assessing both the commercial and subsistence roles of these products and comparing them with the possible income from logging and other land uses. The research has served to create a wave of interest in the group of goods called 'non-timber forest products' (NTFPs), which include a great variety of forest resources used for both domestic and commercial purposes. This recent interest has led to an increased awareness of their overall importance for people both in forest communities and in cities.

During the last 15 years, governmental and non-governmental organisations (NGOs) have given their attention and support to various activities related to non-timber forest products (NTFPs), with the aim of improving the livelihoods of families living in or near forests. Some of these initiatives have been effective in achieving social, economic or conservation 
goals. Overall results, however, have been mixed, partly because of the great diversity of conditions and the differing circumstances under which forest resources are harvested, processed and traded. In addition the short-term timeframes of many projects do not provide the depth of understanding required for a range of products as complex as NTFPs and for the design of workable interventions.

\section{Sharing knowledge about forest products}

Many researchers have studied forest products in different parts of the world using methods from various disciplines, including forestry, economics and anthropology. While these studies have increased our knowledge about forest resources, they have also raised important new questions. Because of the widely differing methods used, however, it has been difficult to compare the studies and draw general lessons. To overcome this problem, a group of researchers from around the world recently combined efforts to compare and contrast individual case studies. This collaborative research project, coordinated by the Center for International Forestry Research (CIFOR), with major funding from the UK Department for International Development (DFID), included 61 cases of forest product commercialisation from Asia, Africa and Latin America. CIFOR worked with small teams and individual researchers, representing 47 universities, government research agencies and NGOs from 27 different countries. The researchers, who included ecologists, foresters, agronomists and anthropologists, wanted to gain a better understanding of the wide range of conditions that influence whether NTFP trade benefits rural people and helps to conserve forests and if so, how.

CIFOR has published the in-depth, three-volume set of scientific reports focusing on Asia, Africa and Latin America entitled Forest Products, Livelihoods and Conservation: Casestudies of NTFP Systems. The researchers were also keen to share their knowledge about forest resources with a more general audience, beyond scientists and donors, using simpler language and an illustrated, briefer format. To achieve this goal, we produced three supplementary volumes: Riches of the Forest: Food, Spices, Crafts and Resins of Asia; Riches of the Forest: For Health, Life and Spirit in Africa; and Riches of the Forest: Fruits, Remedies and Handicrafts in Latin America.

The volume in your hands is one of the products of the researchers' collaborative efforts. The 38 researchers involved in the Latin American case studies explain how a selection of forest resources are harvested, processed and traded. Consumers generally go to markets, stores and bazaars, choosing and buying food and goods like decorative or beauty products without knowing much, if anything, about the history of these products or the people involved in their collection and sale. This effort comes at a time when forest cover worldwide is decreasing rapidly, and forest-reliant communities must rapidly respond to change. 


\section{The case studies}

This volume brings to life 24 case studies featuring forest plants and animals. The botanical cases are presented according to the main part of the plant being used - the fruit, bark, roots or wood. Sometimes a plant has multiple uses, or different cultures may use the same part of a particular plant in different ways. In each case, the contributors describe the main characteristics of the forest product, its history, harvesting and management, and how it is processed and traded. In closing, each author comments briefly on trends and current issues regarding the resource. The final chapter reviews common themes and lessons that can be drawn from these cases.

Throughout the following cases, an asterisk (") denotes words for which definitions can be found in the glossary at the end of the book. At the start of each case, you will notice the scientific name of the forest plant profiled. A full explanation about the use of scientific names can also be found in the glossary. 


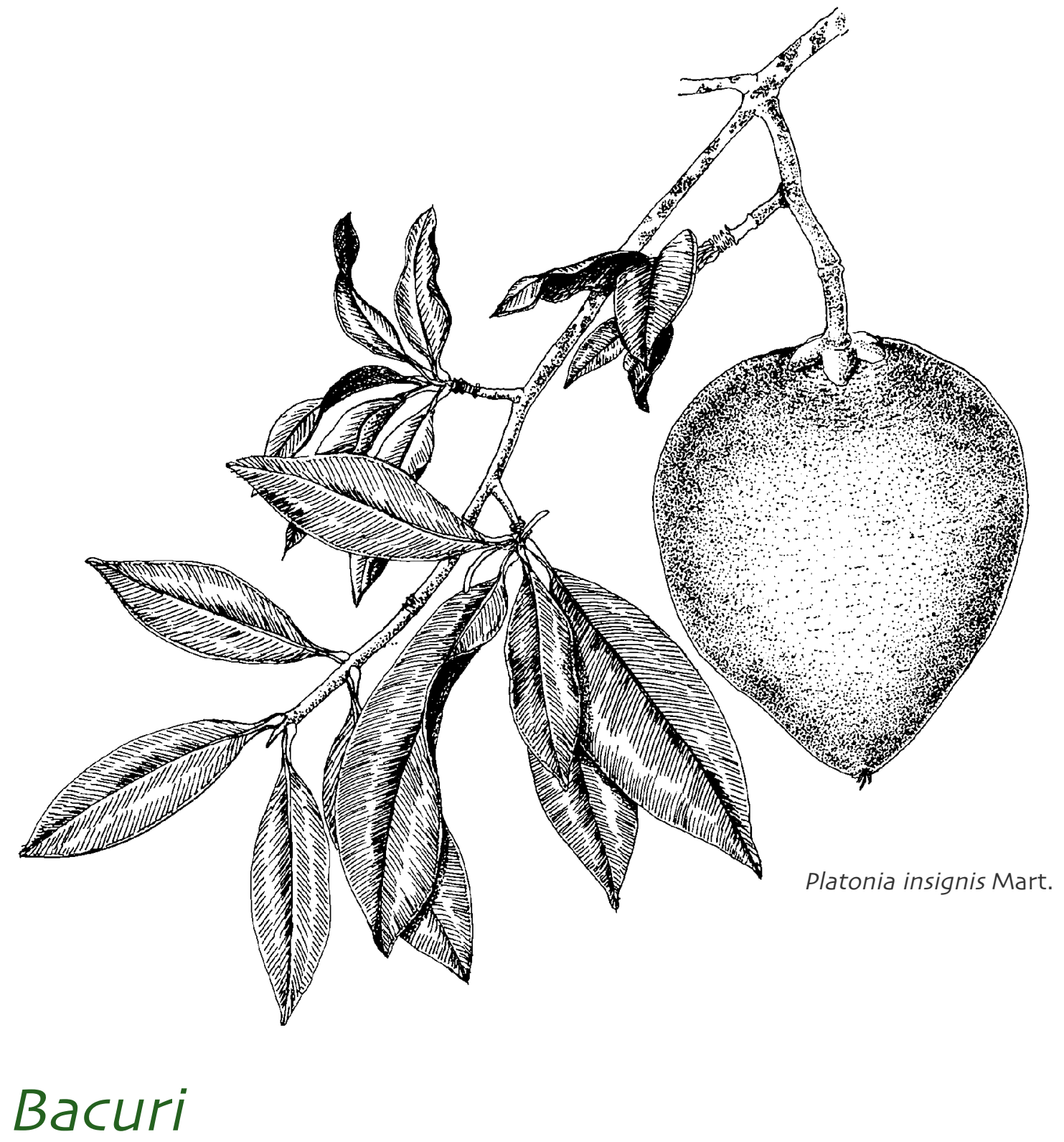

Brazilian case by Socorro Ferreira and Gabriel Medina 


\section{Bacuri: Gold in the market, delicious in the mouth}

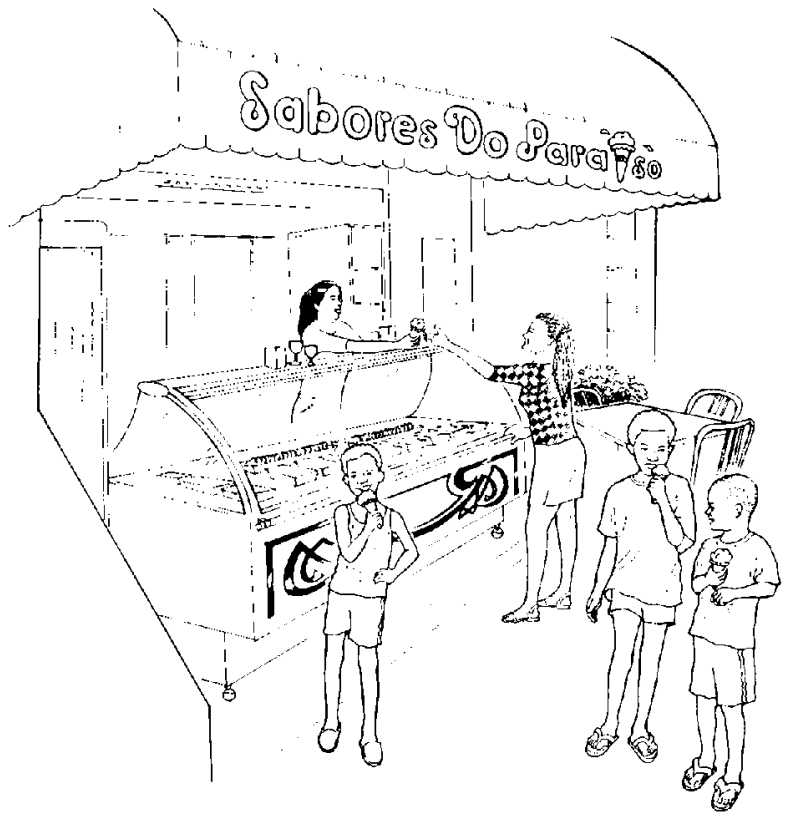

Children in Belém and other cities in northern Brazil enjoy the delicious flavour of bacuri ice-creams.
Have you ever noticed that every time you sample a new fruit you try to associate its flavour with one that you already know? This is next to impossible in Amazonia however, because the multitude of native fruits have quite unique tastes. Ice-cream and juice shops boast more than 50 different fruit flavours, attesting to the region's extraordinary biodiversity* and the cultural importance of its aromatic, flavoursome produce. Of the abundant fruits, locals know what few outsiders do - that bacuri (Platonia insignis), a native* fruit of the forest, is one of the best.

Bacuri's tasty white pulp* is extremely popular in northern Brazil. In the state of Pará, some rural families are known to consume more than 600 fresh fruits during bacuri's four-month fruiting season. The distinctive flavour also features in a range of goods - from puddings and ice-creams, to juices, jellies, yogurts and

liqueurs. But bacuri yields more than just fruit. Its seeds are the source of an oil, while the sticky yellow latex that oozes from wounds in the bark is used as a home-made glue and plaster, and in the treatment of eczema, herpes and other skin diseases. Bacuri's high quality, durable timber is also widely sought after.

Until recently, few people paid much attention to bacuri despite its myriad uses. Like uxi fruit (see the uxi case), it was regarded as a "fruit of the poor" - cheap and accessible to rural people. But that perception has since changed, given the skyrocketing urban demand and rising market value. As one street vendor explains: "Bacuri is turning to gold in the market". In response to the rising prices, others say: "The fruit of the poor has become the fruit of the rich!" 


\section{Thriving in degraded landscapes}

Bacuri is native to the Brazilian state of Pará, where the highest concentrations grow in the Salgado, Bragantina, and Marajó Island regions. The trees are large and impressive, reaching $25 \mathrm{~m}$ in height, with trunk diameters of around $1.5 \mathrm{~m}$, and deeply ridged bark. In dark, old-growth forests*, the bacuri trees are few and far between, with an average of only one for every three hectares. But in secondary forests*, where there is more light penetrating the canopy*, bacuri can dominate the landscape, with up to 100 trees per hectare. This dense growth is facilitated by a root system with a vigorous capacity to sprout.

Growing the trees from seed is difficult and takes a long time, so farmers prefer to manage seedlings that sprout spontaneously after land has been cleared or fields have been left fallow:. In secondary forests, farmers thin the seedlings, allowing the most vigorous to grow with reduced competition. Trees managed in this way produce fruit after 12 years, much earlier than trees scattered in mature forests.

\section{The search before sunrise}

During the rainy season when bacuri is fruiting, children living in remote forests awaken before dawn and make their way barefoot through the dark woods, searching for bacuri trees. Under the branches of these magnificent trees, they sample dozens of the delicious

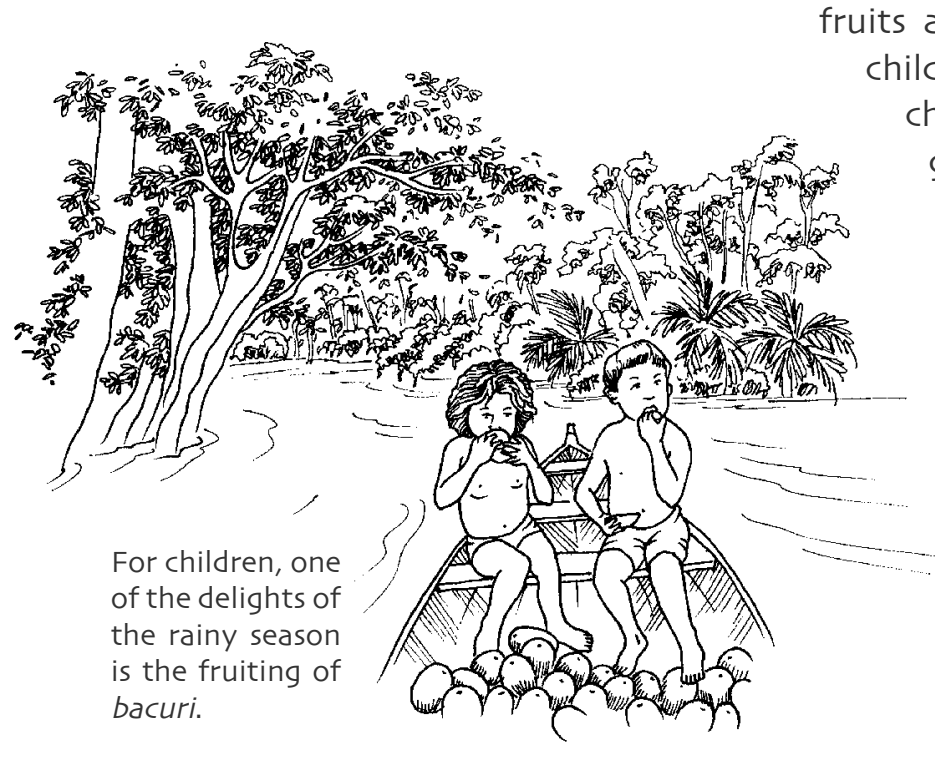

children go early in case their friends beat them to the chase and collect that day's fallen fruit. The thick green rinds* of the mango-sized bacuri are cracked open by hitting them with a strong branch or knocking them hard against the exposed tree roots. With the rind accounting for 60 per cent of the fruit, the seeds 18 per cent, and the white pulp (the edible, fleshy portion of the fruit) just 12 per cent, all this work to get just a mouthful indicates the taste must be well worth it. A single child may eat as many as 40 fruits in one day!

collecting bacuri is easier in managed secondary forests, many of which are close to urban centres, as the trees grow fairly close together. At the height of the fruiting season, women and children 
may pass by the trees two to three times a day to collect fruit. Families sell the fruit or pulp to middlemen, or directly to consumers in the markets of nearby towns. The middlemen sell their supplies to dealers, who process the bacuri fruit for retail trade or sell it to ice-cream shops. In urban centres, women manually separate out the seeds, preparing the fresh pulp for sale or for freezing for later trade. The main trading centre is in Belém, the capital of Pará.

\section{Delicious fruit vs durable timber}

In the Salgado, Bargantina, and Marajó Island regions, one bacuri fruit sells for US\$ 0.02-0.03, but in Belém, each fruit sells for US\$ 0.10-0.33. These prices can double early or late in the season, when the fruit is harder to obtain. As each tree on average, produces around 400 fruits, bacuri has significant potential to raise a family's income in areas close to the markets. This is especially true if fruit sales are compared to selling the whole tree to the timber industry. The price of one bacuri tree sold for timber can be as low as US\$ 0.70. Farmers are realising the value of their bacuri trees, recognising that they will yield fruit and income for many years, whereas the sale of the timber provides a paltry, one-off payment. In remote areas, bacuri is also important as a source of household nutrition.

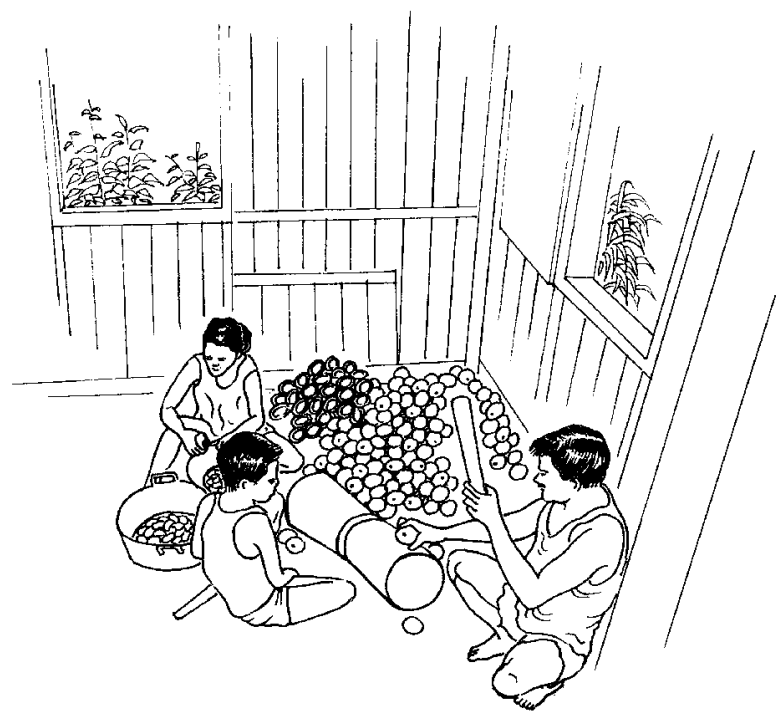

A family works together to split open the bacurifruits, knocking them against something hard or hitting them with strong branches.

\section{Trends}

The ability of bacuri trees to sprout in heavily degraded areas assures their survival. However, one concern is that since bacuri seedlings sprout from the roots of the parent tree, individual bacuri groves in secondary forests can be genetically identical*. Across Amazonia as a whole however, the fruits vary greatly in pulp and flavour, indicating significant genetic* variability. It may be useful to cross breed* 'wild' trees from old growth forests with managed seedlings to enhance desirable characteristics in the fruit and maintain genetic diversity.

To meet the growing market demand for the fruit, farmers are exploring management practices to improve fruit production. In the municipality of Bragança for example, many families are leaving some crop areas fallow to allow for the natural regeneration of bacuri trees. After 12 years, the pay off is a crop that can potentially yield good dividends delicious fruit as well as cash. 


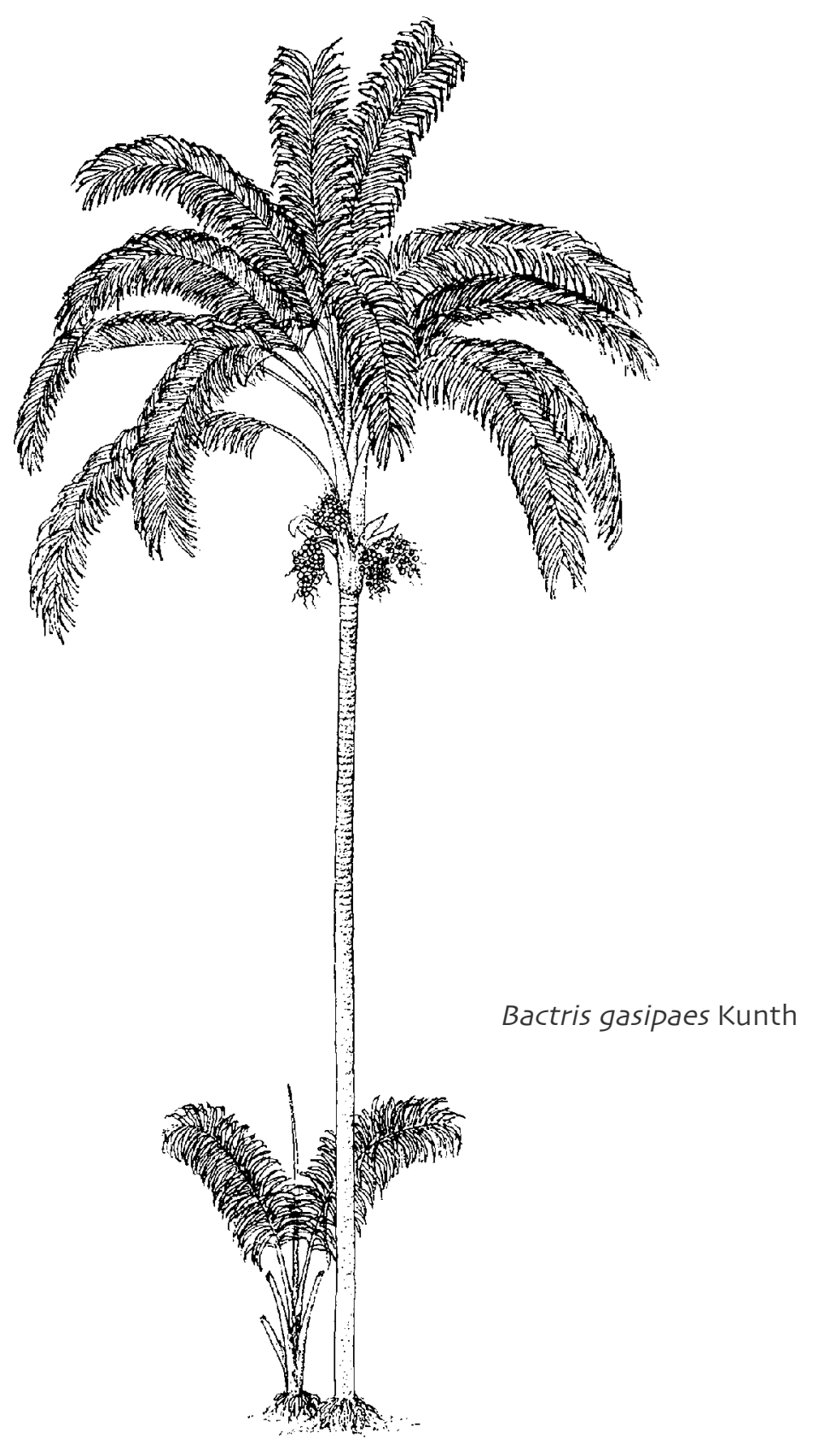

\section{Pupunha}

Brazilian case by Charles R. Clement 


\section{Pupunha: Once a staple, now a snack}

Rural people and urbanites alike, from Costa Rica to the Brazilian Amazon, know and value 'pupunha' for its starchy, oily, energy-rich fruit. The plum-sized fruits come in a range of colours, from bright red to brilliant yellow and everything in between. But harvesting the fruit can be a bit tricky as the tree trunks are heavily armoured with spines which can easily pierce the hands, legs and even rubber boots of those who dare to climb them.

The fruit of pupunha (Bactris gasipaes) has a nutritional composition similar to maize and the red and orange types are rich in vitamin A. When you bite into the cooked flesh, it has a texture not unlike sweet potato or manioc", and a unique flavour, which is a bit of an acquired taste. Like sweet potato, pupunha must be cooked for 30 to 60

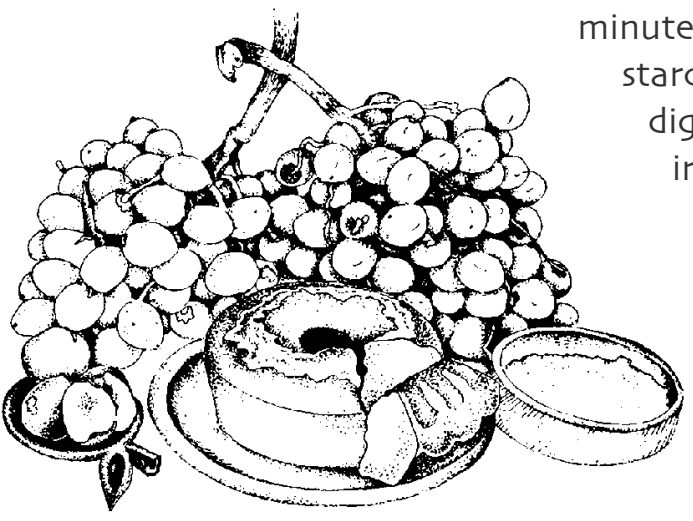

Apart from being cooked and eaten or fermented to make beer, pupunha has traditionally been ground into flour and used for baking. inutes in salty water. This enhances its flavour, breaking down the starch into sugar, destroying an enzyme* that inhibits protein digestion, and dissolving the calcium oxalate crystals* that can irritate the tongue and throat. The cooked fruit is then peeled and pitted, ready for eating as a snack or with coffee at breakfast.

The cooked fruit can also be dried and ground, and either made into an orange-coloured flour used for baking traditional dishes or, in north-western Brazil, fermented into a tasty drink called caissuma. Depending upon the time it ferments, the alcohol content varies - from $4 \%$ (less than beer) to $10 \%$ (as much as wine). A pot of fermenting caissuma smells like peaches, and the resulting drink has a fruity rather than starchy taste. Its aroma is the reason that pupunha is translated as 'peach palm'.

\section{A farm aphrodisiac}

The presence of pupunha in apparently mature open forest is an indicator of past human occupation. Ten thousand years ago, the first Amazonians started using the hard, durable and flexible pupunha wood to make bows and arrows, harpoons, spears and other tools. Before the advent of metal tools, indigenous* groups used wooden pupunha machetes to cut softer vegetation. Over thousands of years, pupunha trees, differing slightly in their characteristics, were planted in and around villages. Through cross-fertilisation*, new variations with larger, starchier fruits were produced, which the indigenous people cooked and ate. The trees were selected for their fruit size and colour, or because they had fewer 


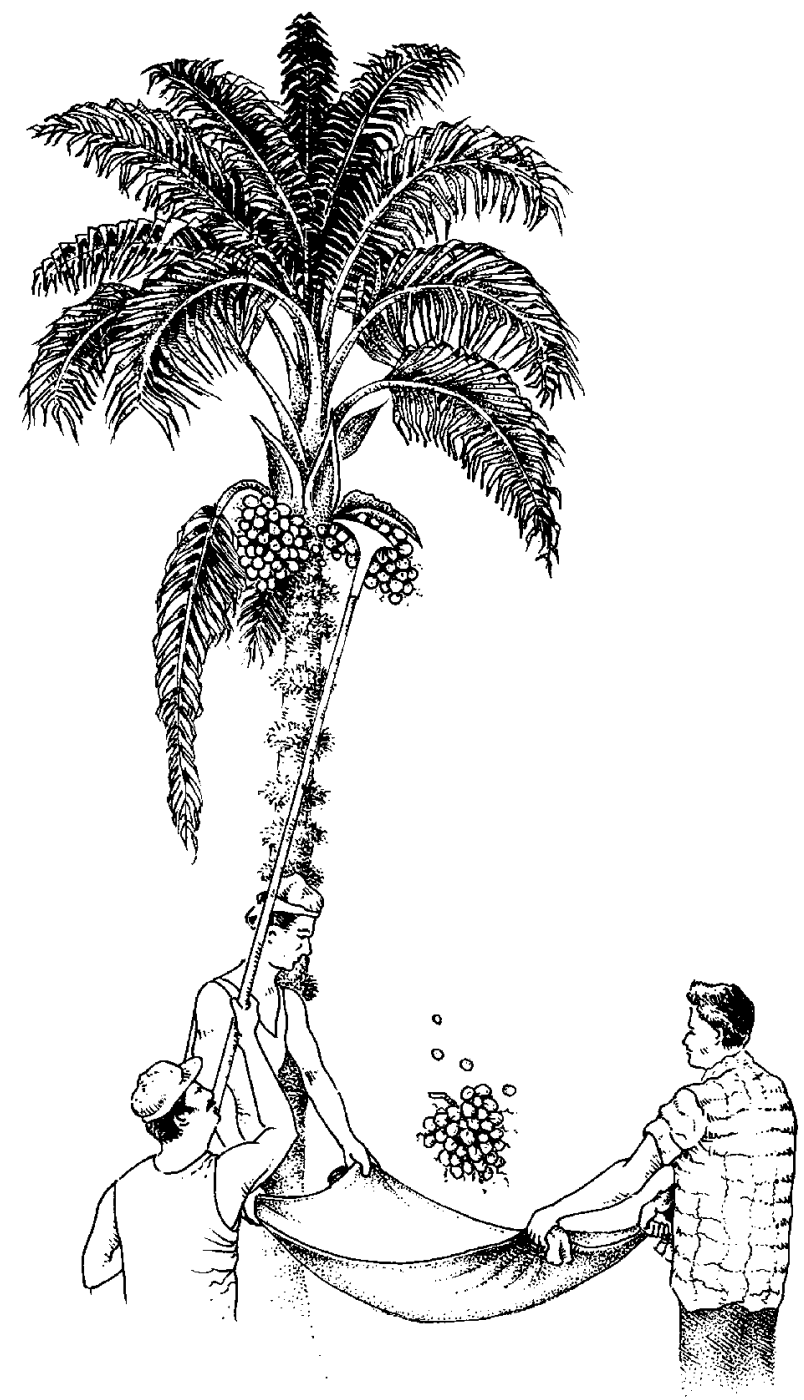

Pupunha grows tall quickly and the bunches of fruit do not all ripen at once, making harvesting difficult and labour intensive. Avoiding the spiny trunks, some harvesters use a long pole with a hook to reach the fruit. Others choose to climb neighbouring trees or build makeshift scaffolding. spines on their stems. Over time, the variation in size and colour increased. Today, the larger varieties of pupunha fruit in western Amazonia can weigh as much as 200 grammes each, making them more of a meal than a snack!

The arrival of the pupunha season was traditionally celebrated with harvest festivals and abundant supplies of caissuma beer and other recreational non-timber forest products. Not surprisingly, nine months later there would be noticeable baby booms in the villages that grew and used pupunha. This coincidence did not go unrecognised and today pupunha is considered an aphrodisiac, especially in Colombia. Nevertheless, the cultural importance of pupunha has diminished over the years, to the point where it is now regarded as a minor crop except amongst some indigenous groups in tropical forests, where pupunha continues to retain its importance as a subsistence food crop and ritual beverage.

\section{Pupunha in home gardens}

When people started planting pupunha in and around their villages the species stopped being a strictly nontimber forest product and became a crop. Pupunha is common in home gardens and also grows quickly in agricultural plots that have been slashed and burned (to prepare the ground for planting or after crops have been harvested), with the trees generally starting to flower and fruit in two to four years. Most families have home gardens where they plant several pupunha trees generally enough to supply household needs and yield about $20 \mathrm{~kg}$ per tree each year. All families have perennial crop plots, usually containing up to 20 different species of fruit trees, but less than half of these plots include pupunha. In other parts of tropical Latin America a greater proportion of plots may include pupunha. 


\section{Street corner sales}

The fresh fruit must be cooked to be edible and is best consumed within two to three days of processing as its shelf-life is very short without refrigeration. The major commercial market for pupunha calls for only simple cooking, with vendors selling the fruit on urban street corners by the half-dozen. A small market for the tree's dark brown, yellow streaked timber also exists, for making furniture, handicrafts and parquetry (wooden floor 'tiling', where small pieces of wood are arranged in mosaic patterns).

Rural households trade pupunha and other farm and forest products in local markets, or sell their goods to intermediaries, while the larger scale producers supply pupunha for the urban markets. Throughout much of tropical Latin America, pupunha street vendors can be found with small carts that allow for the fruits to be boiled on the spot and offered to passers-by. Processing the starchy flesh into flour is starting to attract attention in Amazonia and a small commercial market has been developed in Costa Rica. In northern Brazil, a new fad is the 'café regional', a type of breakfast restaurant specialising in regional foods, including forest fruits - providing another outlet for the larger scale producers and intermediaries. In spite of the Brazilians' strong penchant to party, entrepreneurs in Amazonia have yet to revitalise the demand and market for the fermented fruit drink caissuma.

\section{Lots of data, marginal benefits}

As with most minor crops, farm gate prices for pupunha fruits are low - fetching US\$ 0.250.50 per bunch, sometimes US\$ 1-2 for bigger bunches. Small and large pupunha producers can earn a reasonable income when they are located near urban centres with a strong demand for fruit. Further away from the urban centres, pupunha is more of a marginal subsistence crop that is slowly losing ground to processed starchy products. Three decades of research have generally failed to alter these trends in tropical Latin America. One reason is that government research institutions tend to concentrate on products for large international markets, ignoring subsistence needs. This means small-holders rarely benefit from information and innovation.

In addition, research on 'minor' crops tends to be conducted without adequate understanding of the marketing chains, or the specific barriers to improving production and trade. Researchers need to identify and target consumer preferences in each country, and get the right type of seeds to the farmers. Transforming a marginal crop into a cash crop also requires entrepreneurs, and in the case of pupunha, they have not yet identified clear market opportunities - although the potential for pupunha beer, flour and fruit is there. 


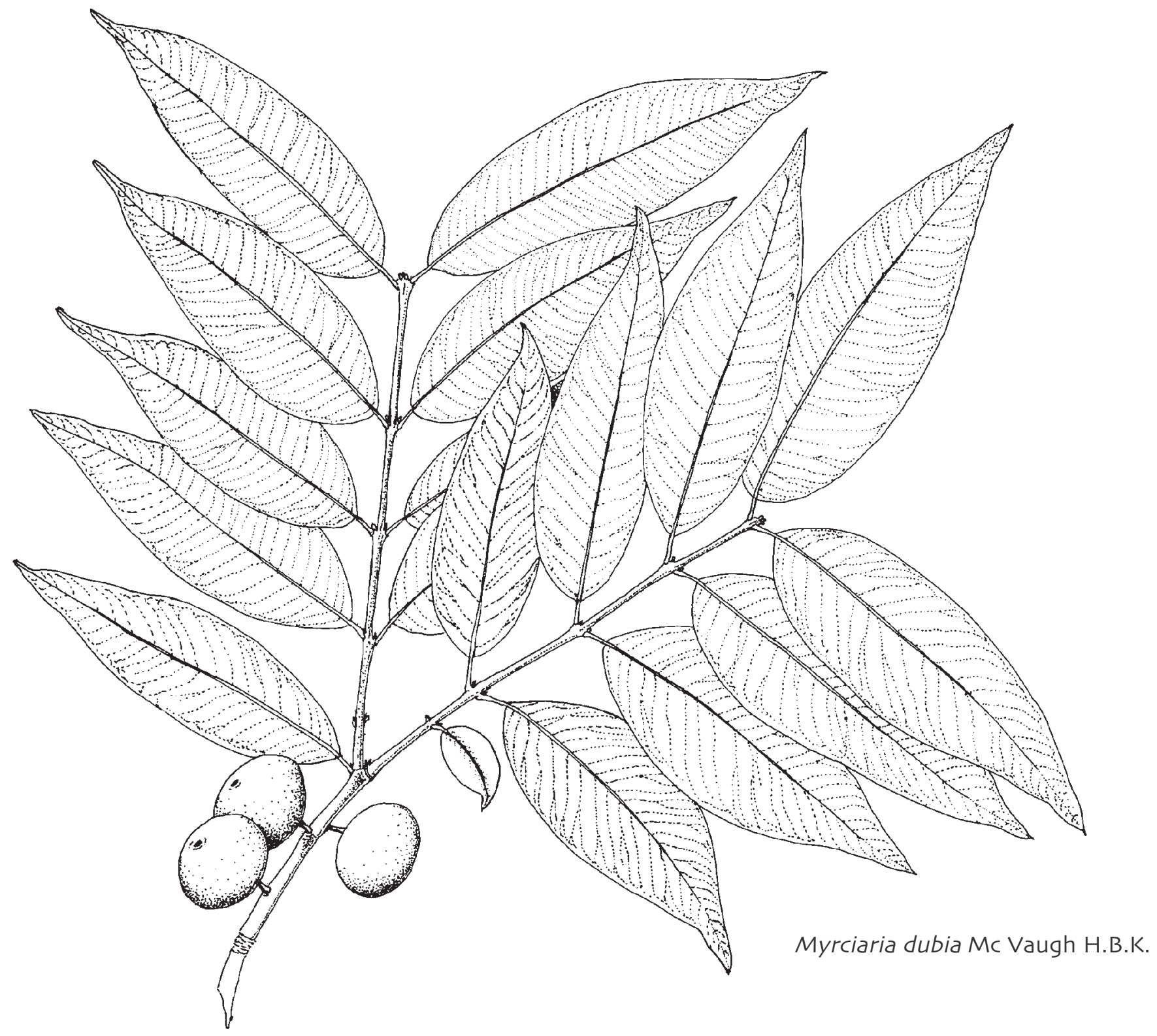

\section{Camu-camu}

Peruvian case by Mario Pinedo Panduro 


\section{Camu-camu: The world's highest vitamin-C content}

Ten years ago, camu-camu fruits were consumed only by the inhabitants of north-eastern Peru. Nowadays, these small purple, plum-like fruits have found favour with a much broader consumer base both within and outside Peru. In fact, throughout the late 1990s, most of the harvested fruit was being exported, mainly to Japan.

In the north-east region of Peru, people sometimes eat the fairly acidic camu-camu fruits fresh, but traditionally they have used them to make refreshments and liquors. They also use the skin of the fruit to create a purple colourant for dying fibres and fabrics, while the fruit itself is sometimes used as a fishing bait. The bark, leaves and roots are also used to make liquors, medicinal syrups and dyes.

Local people squeeze and crush the fruit in water with their hands, separating out the skin and seeds. The remaining fruit pulp* has a pale yellow colour and citrus taste, and makes a refreshing drink when mixed with water. In the Peruvian city of Iquitos, the main trading centre for camu-camu, the fruit pulp is sold fresh or frozen, or is made into drinks and icecreams. Studies in Peru have found that this nutritious fruit has an extremely high level of vitamin-C (3,017 mg per $100 \mathrm{~g})$, approximately 30 to 60 times more than oranges. The fruit also contains beneficial plant fibres, which stimulate the proper functioning of the digestive system, and significant levels of beta-carotene, calcium, iron, niacin, phosphorus, riboflavin, thiamin, flavonoids* and pectins*, some of which assist in the prevention of cancer.

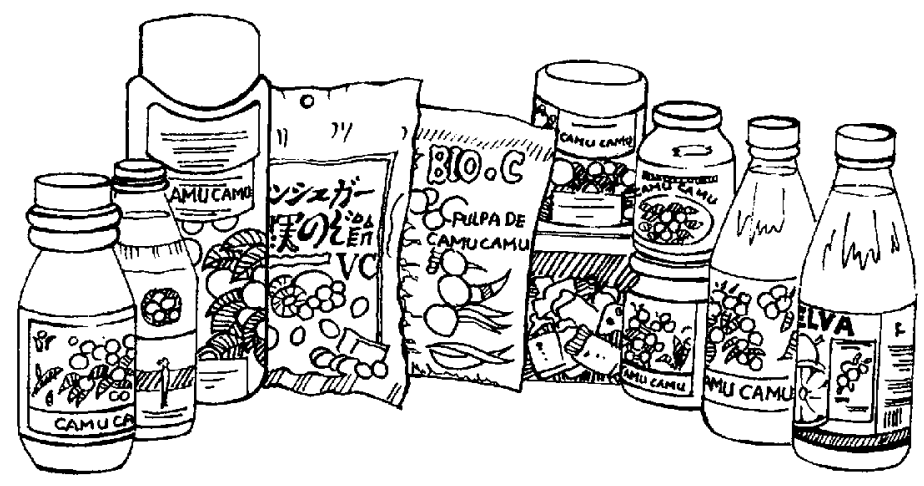

A range of products is derived from the versatile camu-camu fruits, including juices, tablets, candies and shampoos.
In addition, camu-camu possesses anti-rust, anti-inflammatory*, emollient (moisturising) and astringent* properties. In the international marketplace, a diverse range of products are derived from the fruit, including capsules and tablets, and enriched food products like nectars, jams, yogurts, icecreams and caramels. In Brazil, a new line of cosmetic products, including creams and shampoos, are also being produced. 


\section{A resource from flooded areas}

Camu-camu (Myrciaria dubia) is a small tree that grows 4-8 $\mathrm{m}$ in height, in the humid tropics, at altitudes of around $100 \mathrm{~m}$ above sea level. It grows along the banks of rivers and lakes, strongly influenced by the changing levels of water in flood plains*. These small trees can survive not only flooded conditions but can even remain submerged for up to five months.

In addition to growing wild in Peru, camu-camu can also be found within plantations. The degree of elevation has important implications in terms of determining economic outcomes. Harvesting

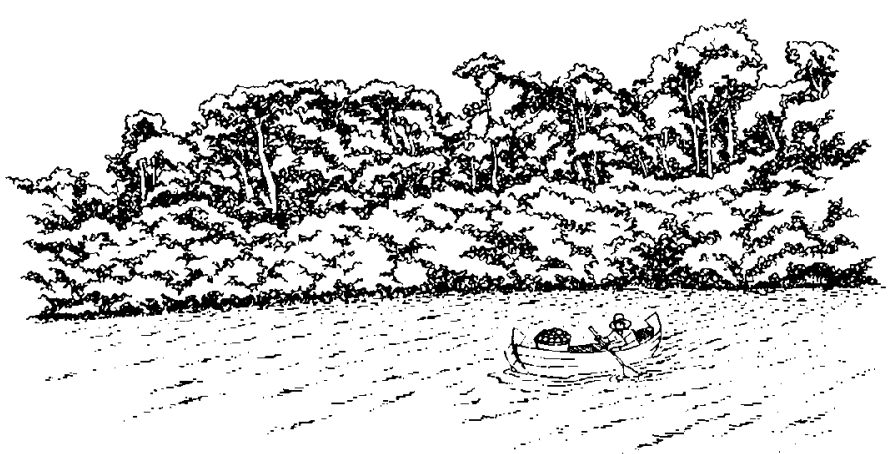

The amount of wild camu-camu fruit that is harvested, and the flow-on socio-economic benefits, largely depend on the changing water levels of rivers and flood plains. coincides with the start of the rainy season and an increase in flooding. This means that in the lowlands, where natural populations occur, a high percentage of the fruit is lost. Such losses however, do not occur at higher elevations where camu-camu is cultivated, as changes in water levels are less drastic.

Harvesting from either plantations or wild populations does not have detrimental consequences on the plants or their environment as only the fruits are collected, without causing damage to the branches or leaves. The plants themselves remain unharmed and able to regenerate, guaranteeing future supplies. Currently, more than 90 per cent of the harvested camu-camu comes from wild populations. An estimated 5 tonnes of wild fruit can be collected from an average hectare. Cultivation in plantations began in 1997, although there has since been little in the way of continued expansion in order to significantly increase cultivated supplies. For Peru as a whole, the annual harvest of camu-camu is estimated to be around 6,760 tonnes of fresh fruit, with the extracted pulp representing an annual income of approximately US\$ 11.8 million.

\section{Fruit collection from canoes}

The income received from camu-camu is important for many families living along Peru's Amazonian rivers. One family, representing an average two parents and three children, can harvest around $200 \mathrm{~kg}$ of fruit per day. This represents an income of about US\$ 20, whereas the minimum daily wage is around US\$ 3 per adult. The harvesters only collect the dark red fruits as these have the highest vitamin-C content. 
Fruit producers sell their harvest to intermediaries or processors, who arrive at their village settlements in boats equipped to process the fruit. The pulp is separated from the rind" and seeds, and is immediately frozen. An alternative step involves dehydrating the fruit pulp, reducing the volume and weight by 50 to 90 per cent. The nutritional value of camu-camu is highest in the fresh fruit, so immediate processing helps to retain the benefits. When demand decreases, the fruit producers transport their goods to Iquitos, where they sell them directly to processors. Their long boat journey to the city can take up to two days.

\section{The future for camu-camu}

Despite the fruit producers not being organised into associations or co-operatives - which has weakened their capacity to negotiate better prices - camu-camu harvesting remains one of the most important economic options for many families living in the Peruvian Amazon. Fresh camu-camu fruits and the various products derived from them are continuously in demand in Peruvian cities and local villages. At the national level, substantial benefits are obtained from selling the fruit and semi-processed products.

At the international level however, export gains have been in decline over the last few years.

This is believed to be due to factors such as the instability surrounding the change of government in Peru in 2000. This change affected commercial relations with the main export country, Japan, and led to significant cost increases for importers. Export requirements for value-adding exceeded the processing capacity of Peru and the pulp quality was also brought into question. Importers started to seek cheaper, more stable alternatives.

The fruit of a plant called acerola (Malgihphia glabra), which has similar properties to camu-camu, is now competing with it in the international marketplace. Despite the growing popularity of acerola however, the health benefits from camu-camu are actually greater. Camu-camu fruits have a higher vitamin-C content, which is of particular use in treating a wide range of ailments, and they also possess important metabolites for nutrition and health.

The domestic consumption of camu-camu in Peru will remain strong, and it is expected that the international market for the product will improve once again. Factors favouring this include the external promotion of camu-camu consumption, the stabilisation of the price of the fruit, and the capture of new international niches. Camu-camu fruit has considerable potential as an 'organic product ${ }^{* 1}$, being mainly collected from flooded areas in Peru, free from agrochemicals*, and largely harvested in a sustainable* way.

Harvesters travel in canoes and pick camucamu fruits by hand, collecting them into large plastic containers. 


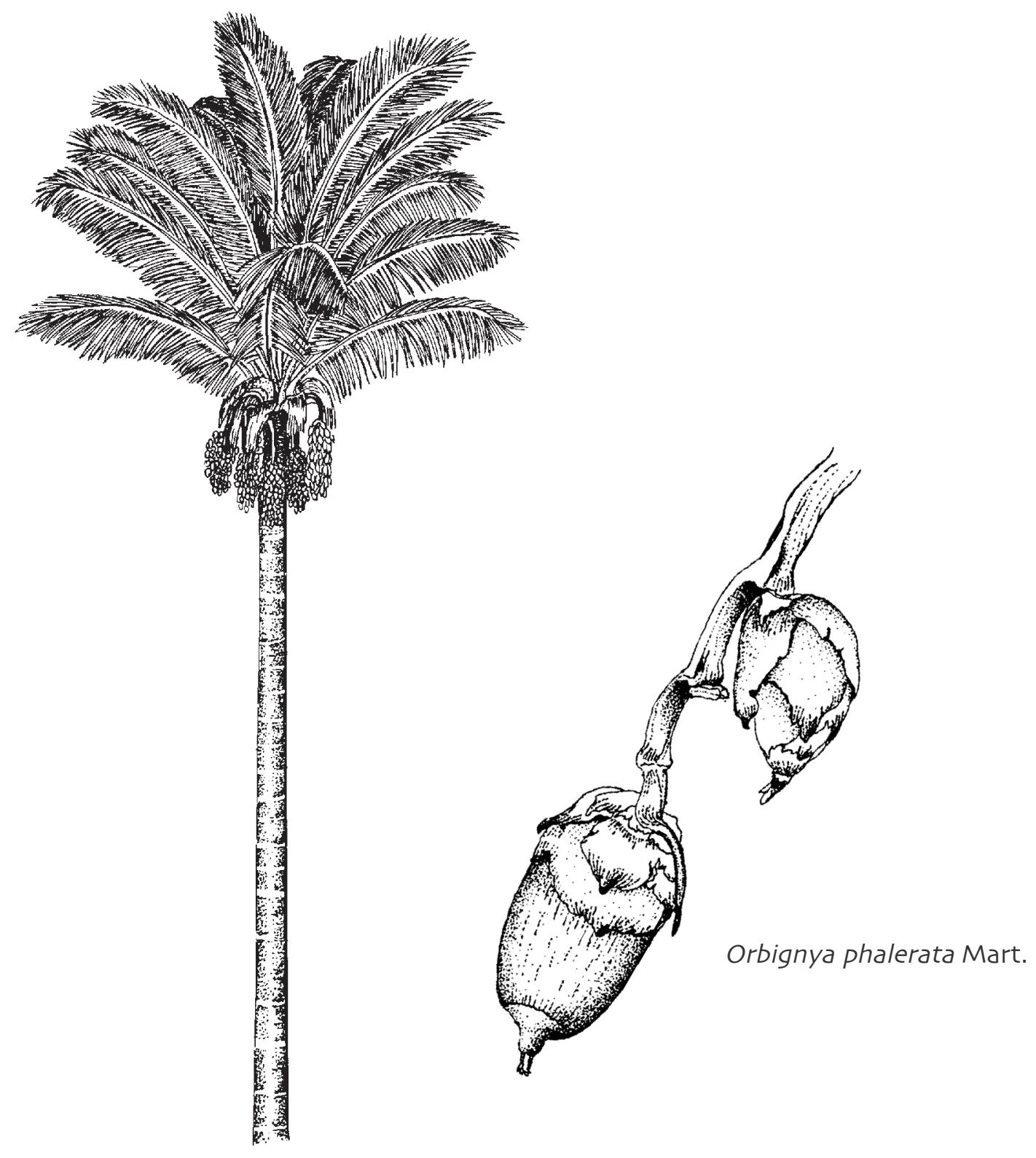

\section{Babassu}

Brazilian case by Claudio Urbano B. Pinheiro 


\section{Babassu: A multi-purpose and pervasive palm}

The "tree of life" is a fitting name for north-eastern Brazil's babassu palm. Nearly every part of this versatile plant can be used as a source of food, shelter or ingredients for soaps and cosmetics. Nature is to thank for the combination of so many practical and useful functions in this single plant.

For more than a century, babassu palms (Orbignya phalerata) have been a cornerstone of subsistence living for rural people in the north-eastern state of Maranhão. The babassu displays all its virtues in the rural household economy. Babassu fruits and nuts remain an important source of food for people and animals (like certain rodents and even pigs, chickens, etc). A type of milk and an edible oil can be produced from the nuts, while babassu flour is made from the leathery flesh of the fruit. This flour can be used as a substitute for manioc" flour or as a form of livestock feed. The inner part of the fruit has another important use as well - it can be burnt and turned into charcoal, a common source of domestic fuel for cooking.

In addition to feeding families, various parts of the babassu palms provide shelter from the harsh sun, and from rain in the wet season. Farmhouses and many of the items found within them are largely made from babassu palms. The trunks of

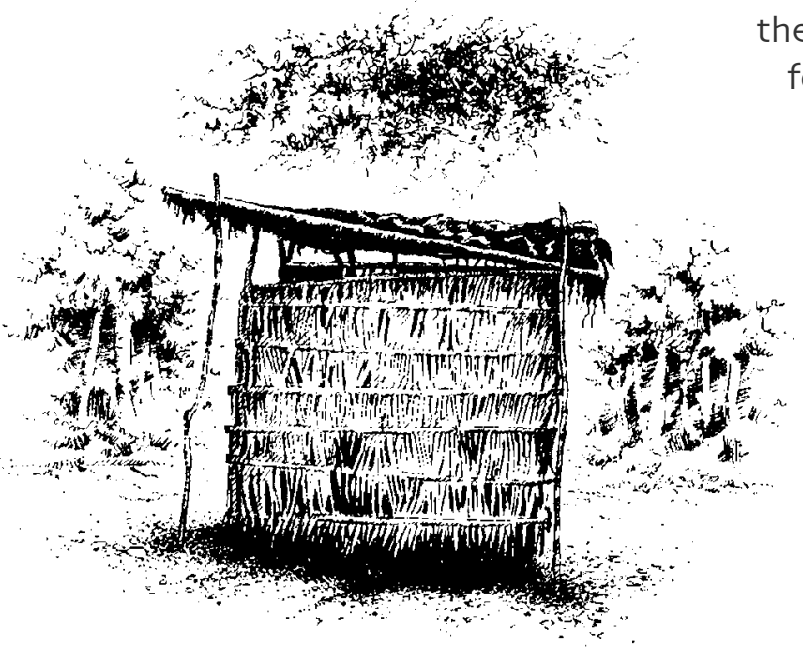

A multi-purpose plant. The fronds or leaves of the babassu palm are used to build traditional huts. the palm make an excellent construction material (e.g. as foundational poles and for making benches, while the entire stems can be used to construct bridges), and the fronds or leaves are perfect for making thatched roofs. Inside the home, babassu is used to make baskets, brooms, mats, and a number of other household items.

In addition to its subsistence uses, babassu is also an important source of cash for rural families. More than one million people in the state of Maranhão are involved in gathering and cracking open babassu fruits to extract and sell the nuts. These kernels are comprised of about 60 per cent oil and are used industrially in the manufacture of soap and cosmetic products. Babassu oil is quite rich in a substance called lauric acid, which has a composition similar to extracts from the oils of coconuts (Cocos nucifera) and oil palms (Elaeis guineensis). 


\section{Babassu palms: Growing wild}

Babassu is an agressive native* species that grows very well and quickly under many different ecological conditions. These palms cover extensive areas in north-eastern Brazil, especially in Maranhão, where they form forest-like expanses known as babacuais, extending over more than 10 million hectares. At first glance a babasual looks like a plantation because there are so many babassu palms growing together. But the palms grow spontaneously in degraded lands or when native forest is cut down, being resistant to fire and able to thrive in sunny areas.

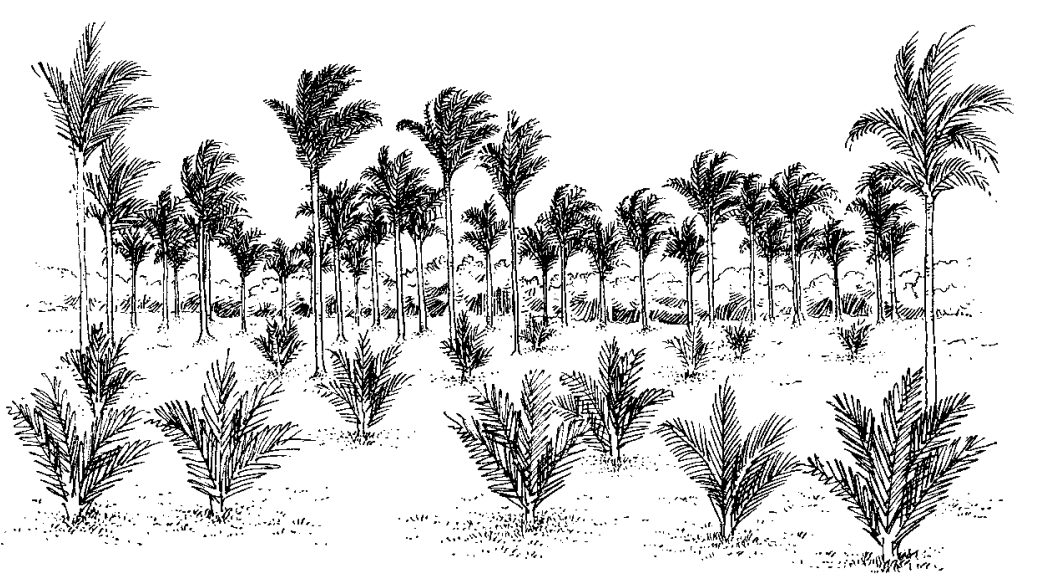

Babassu grows spontaneously across north-eastern Brazil, forming expanses of babassu-dominated forest known as babacuais. These areas resemble plantations in appearance due to the high density of the palms.

Such abundant growth can make it difficult for farmers who want to plant crops or ranchers who want to raise cattle. When they start to establish new agricultural fields, landholders must work hard to clear space and cut down the palms. The landholders generally remove old or unproductive palms, usually leaving 50 to 100 palms per hectare. Even though babassu covers such a broad area in northern Brazil, its distribution is actually diminishing because of the extent to which land-use changes are taking place, including the conversion of land to pasture.

\section{A tough fruit to crack}

A babassu forest produces an average 1.7 tonnes of fruit per hectare each year. Local people gather the fruit after it falls to the ground. All family members may help with the collection of fruit, but it is mostly the men who carry out this activity. Women traditionally undertake the laborious task of cracking the fruits open. This activity has acquired special meaning because the sale of kernels represents the only source of income generated exclusively by women. Known as 'babassu crackers', these women spend days sitting on the floor engaged in the tedious task of removing the nuts from the rock-hard fruits, sometimes with help from their children. They balance individual pieces of fruit on the head of an upturned axe, using a mallet to crack them open. Two or three strokes are usually necessary in order to access all the nuts within a given fruit, and after a hard day's work, 5 to $8 \mathrm{~kg}$ of kernels can be extracted in this way. 
The babassu nuts are sold to local traders, who resell them to industrial oil processors. Local processing, largely the domain of women, is restricted to nut extraction. It is in the factories that the nuts are squeezed or a solvent is used to extract the oil. This raw material is then refined and sold as an ingredient for the manufacturing of goods like skin care products.

\section{"Green insurance"}

Maranhão is one of the poorest states in Brazil, and prospects for regional development currently appear fairly limited. Babassu is an important plant species for people in this part of the world, offering a vital source of income and sustenance for thousands of poor families. The market for babassu oil and starch is consolidated and stable, while the market for charcoal is growing. Under these circumstances, the harvesting and selling of babassu nuts and fruit products will continue to serve as a type of "green insurance" against future crop failures. The plant's subsistence uses will also continue to play a crucial role in rural households. The local socio-economic importance of babassu fruits, coupled with the fact that harvesting does not harm or kill the palms, helps to guarantee the future of this versatile and useful species.
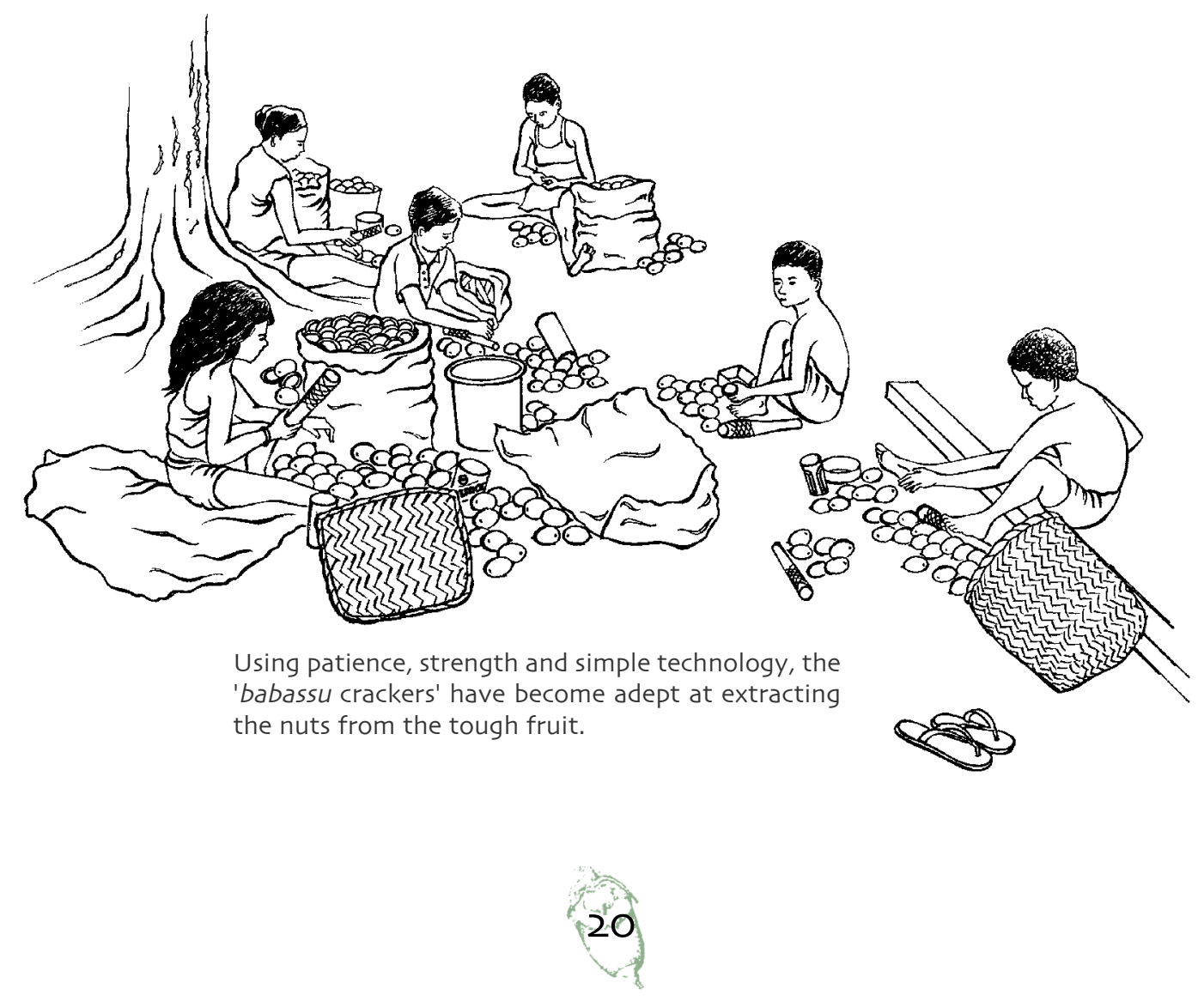


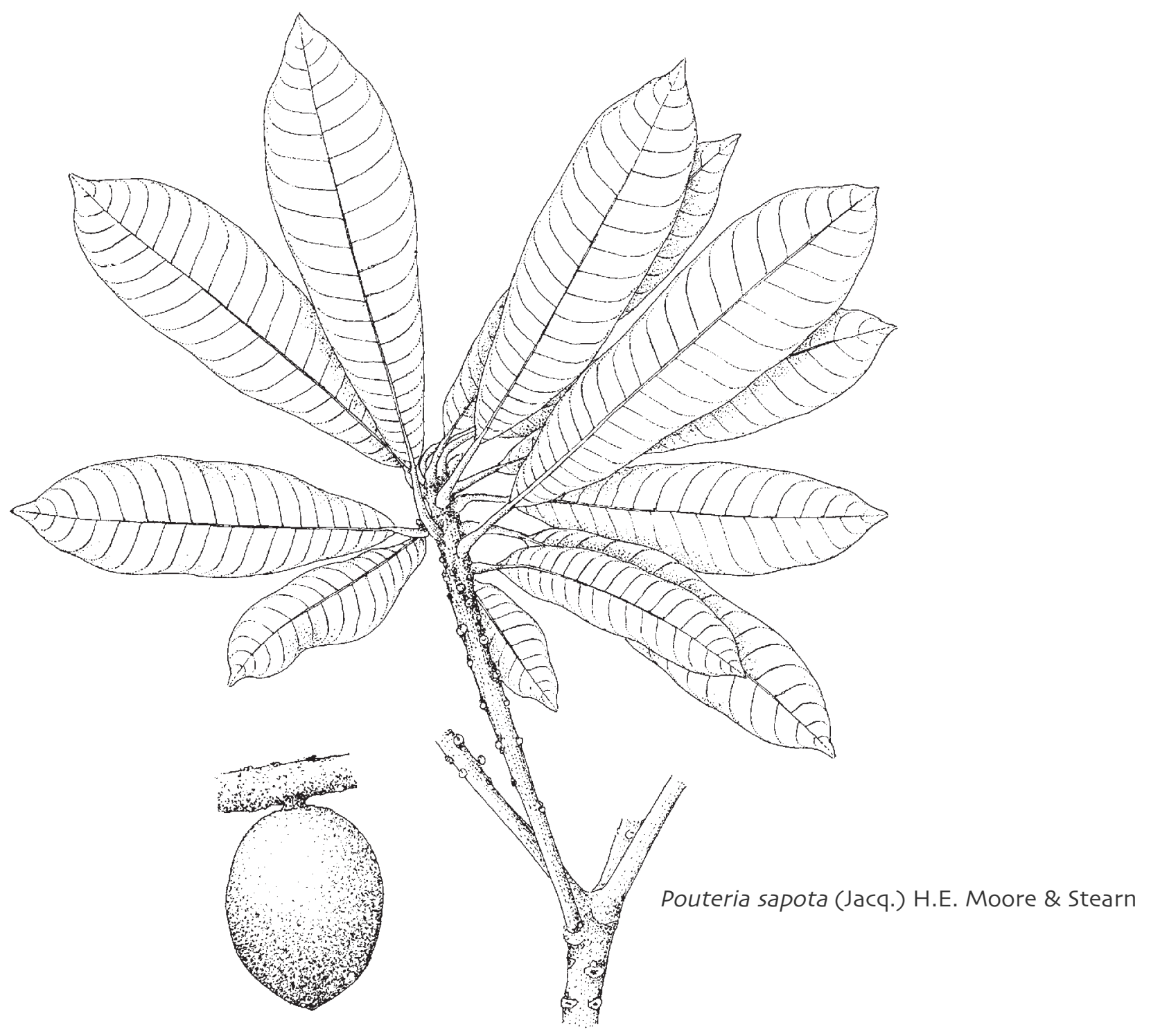

\section{Zapote mamey}

Mexican case by Yolanda Nava-Cruz and Martin Ricker 


\section{Zapote mamey: Sweet fruit of the Maya}

Long before the Spaniards arrived in Mexico, indigenous" groups of south Mexico, including the ancient Maya civilisation, appreciated the remarkable 'zapote mamey' (Pouteria sapota). Its fruit was so sought after that the Maya used it to pay tributes, a type of tax. The cultivation of mamey and other fruit trees was so integral to the Mayan sense of cultural identity that the Spaniards resorted to cutting down household orchards to exert their authority and force the Maya of Yucatán to leave their homeland and resettle in newly established missionary centres.

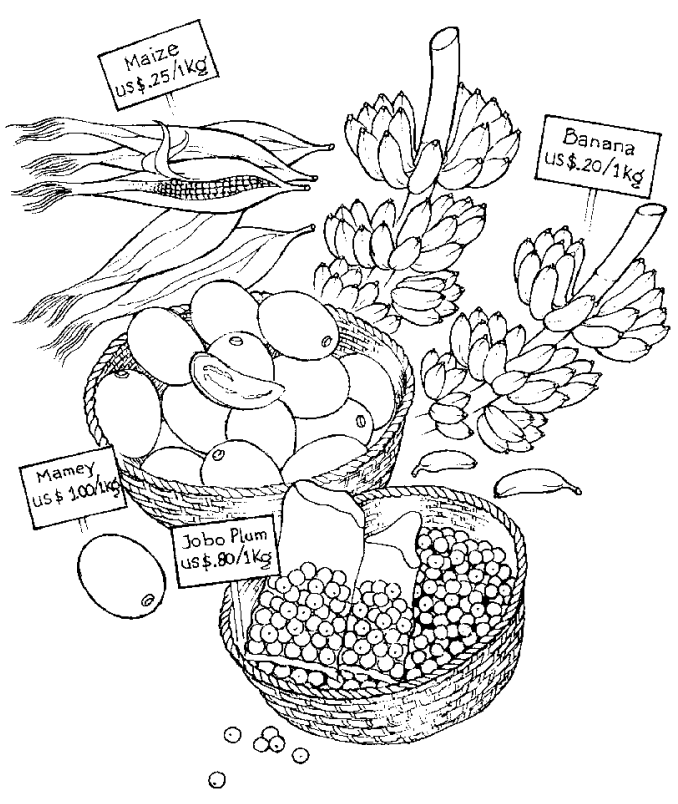

With its roots in indigenous culture, the delicious mamey fruit has become a luxury item in southern and central Mexican cities.
The Spaniards may have succeeded in shifting the Maya away from their ancestral homes, but the Mayan people did not lose their connection to zapote mamey, and continued to make the most of this versatile tree. Today, products made from the fruits, seeds, sap and timber of this native* tree are commonly found in southern Mexican households. The fruit is a reddish-salmon colour, with a sweet pulp that is enjoyed for its mild yet exquisite flavour. Mexicans use it to prepare drinks, gelatins, ice-creams and sweet pies. Oil extracted from the seeds is used by the cosmetic industry, and on a local level it is commonly used as a conditioner to make hair shine. The wood is used for construction and the latex sap is sometimes combined with chicle latex (a milky-white exudate from 'chicozapote' trees (Manilkara sapota)), to produce chewing gum.

Mamey fruit is harvested and sold in the central and southern states of Mexico, including the municipality of San Andres Tuxtla in Veracruz. Its delicious flavour makes it far more expensive than other fruits like oranges and mangoes, so it is considered a luxury. 


\section{Unrealised potential at home}

Botanists are not certain about the origin of zapote mamey but it is believed to be native to southern Mexico and northern Central America. It has since been introduced into many other countries however, and is now cultivated in plantations as far afield as the southern United States, the Philippines, Indonesia, Malaysia, Vietnam and India. Unlike these other countries, Mexicans generally do not distinguish different varieties, and do not grow the trees in monoculture* plantations. Instead, they rely mainly on trees growing naturally in the wild or in small household orchards.

In the municipality of San Andrés Tuxtla, mamey trees are found

in evergreen* forests and forest fragments. Their distribution is quite sparse, with perhaps only one tree per hectare, so harvesters must spend a fair amount of time traveling between the trees to collect fruit. Frequently, two or three trees can also be found growing amongst several other types of fruit trees in family orchards. The mamey trees have great potential to be managed within semi-natural forest systems". The natural diversity of such systems offers many benefits, through combining multiple species that have different uses - such as plants for food and medicine, and trees for wood production.

\section{Ready for harvest}

Mamey trees are tall, reaching a height of up to $40 \mathrm{~m}$. The trees start to produce fruit when they are between 15 and 18 years old. Collectors generally harvest the fruits between May and July when they start to ripen. The collectors first spend quite a bit of time locating trees with an adequate number of potentially harvestable fruits. They then negotiate the harvesting price with the owners of the trees or land, and later return to collect the fruit.

Harvesters need to climb the tall mamey trees in order to access the fruit. 


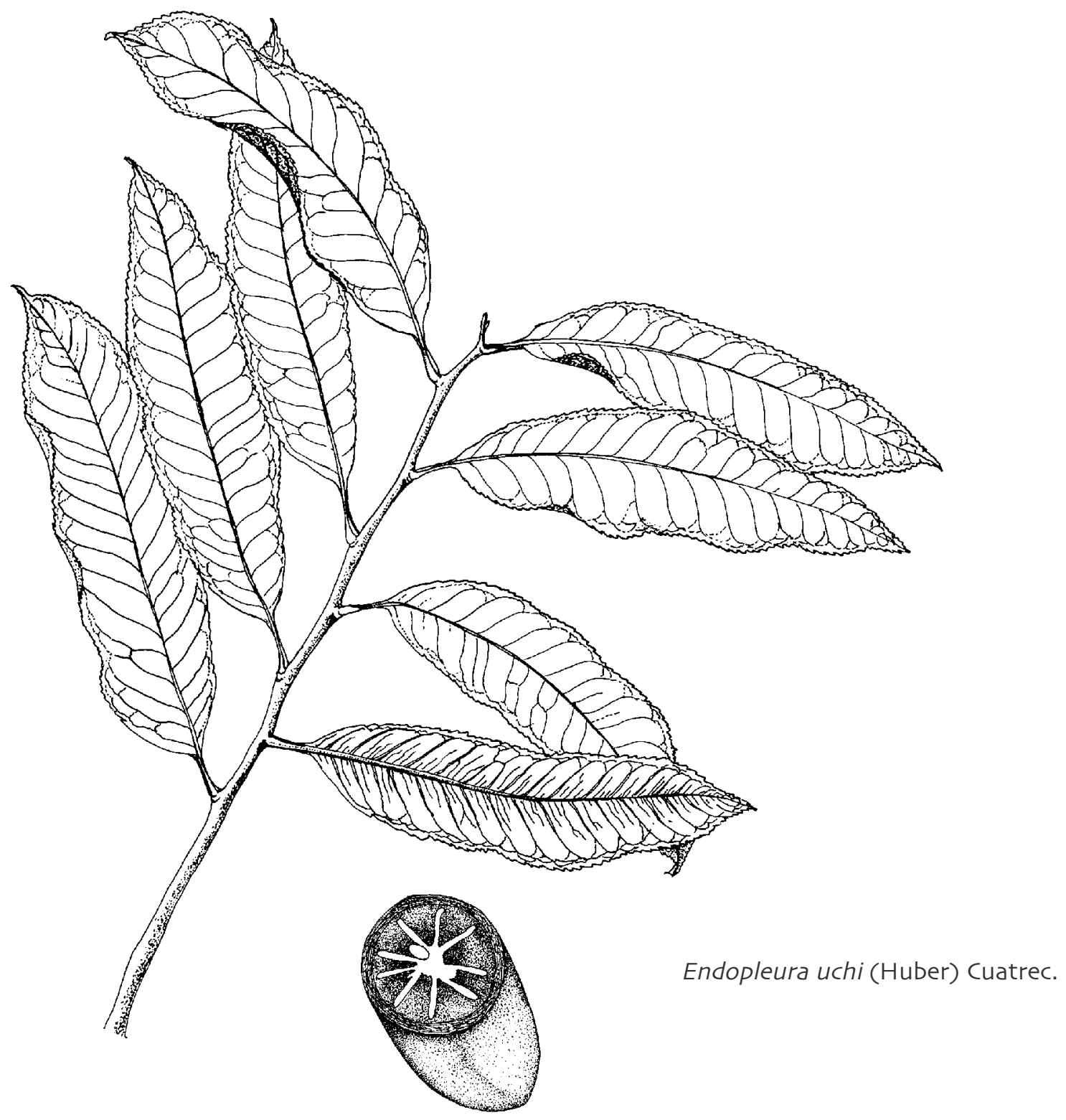

\section{Uxi}

Brazilian case by Patricia Shanley and Gloria Gaia 


\section{Uxi: "Poor man's fruit" a rich taste from Amazonia}

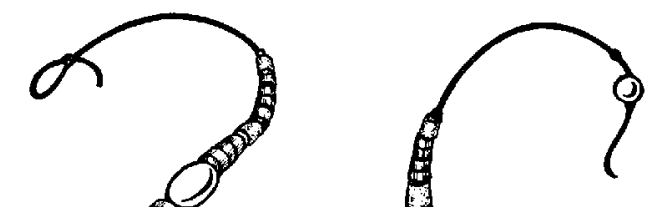

Forest people who consume uxi, a greenish egg-shaped fruit from the Amazon, say that they never get sick or weak during the fruiting season. Rich in vitamin and minerals, uxi was known as the "fruit of the poor" due to its cheap price and accessibility. Today, all Amazonians enjoy this versatile fruit - fresh or in the form of uxi juice, popsicles or ice creams. In addition to uxi's high nutritional value for humans, the fruit also helps to sustain a wide variety of Amazonian wildlife, while the bark is used to make a tea to treat arthritis, diabetes and high cholesterol. The hard case enclosing the fruit's seeds (known as the endocarp*) can also be used as a powerful amulet in jewelry-making.

Bio-jewelry fashioned from uxi is reminiscent of earlier times when the seed cases were traditionally used as amulets.

So why doesn't your local supermarket stock this nutritious botanical delight? In the first place, there are not enough of these yellowish-green and brown fruits to export. Uxi (Endopleura uchi) is often collected from wild trees, but they grow quite sparsely, with an average of only one tree every $1-2 \mathrm{~km}$. Although farmers in semi-urban areas near markets are successfully boosting production by managing the trees, all of their produce is locally consumed. Ice-cream shops stock up on uxi when it is fruiting, but they often run out of pulp* in the off-season. The pulp of the uxi fruit is gritty, oily and high in calories. These are especially desirable qualities for forest people who need energy rich foods to sustain their hard work.

\section{Farmers know best}

Uxi grows in the Brazilian states of Pará and Amazonas. It has been studied very little, so forest farmers know more than scientists about how to grow and manage the trees, and how to use and sell the fruit. In forests with little to no management, wild uxi trees occur in low densities (usually less than one per hectare) and do not bear fruit for the first 15-20 years. But in the Amazon estuary near the city of Belém, farmers have discovered ways to encourage the trees to produce fruit after only nine years. They have also managed to increase the densities of $u x i$ to more than 30 productive trees per hectare. To encourage production and the growth of new trees, the farmers weed and clear away competing vegetation, place mulch* beneath the uxi trees, transplant seedlings*, and remove ant nests with the use of fire. On average, each uxi tree produces around 2,000 fruits during its three to four month fruiting season, but some trees produce as many as 5,000. 
If you want to try uxi fresh from the tree, or to collect it for market, you need to pass by the trees frequently, before the fruits are eaten by appreciative peccary, paca, deer, armadillo and squirrels. In one season, a study of 24 trees in a 200hectare area revealed that animals ate 80 per cent of the fruit! Some forest families, like Senõr Chuva's, in the state of Pará, do not begrudge the loss however - taking advantage of the wildlife's fondness for uxi as an opportunity to supplement their own diets. By setting traps beneath the trees during the fruiting season Senõr Chuva's family and neighbours enjoy a source of wild protein on a daily basis, just as though they had a fresh meat market right next door!

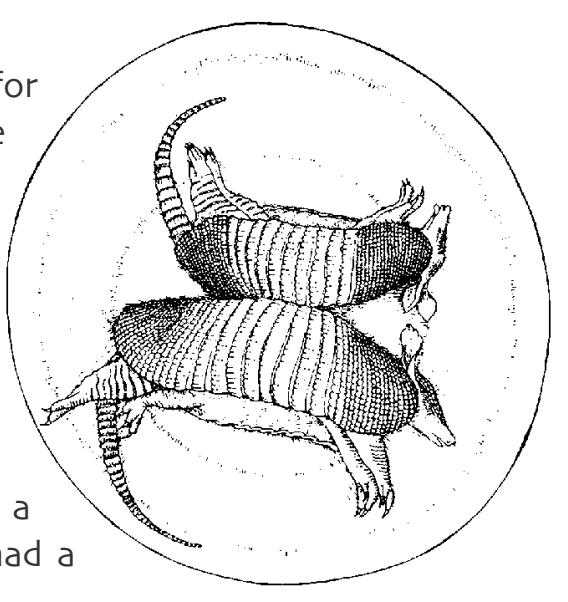

\section{"Poor man's fruit" turns a profit}

Uxi are a favorite fruit of armadillos which hunters capture beneath the tree.

A small number of older people living in remote areas use traditional techniques to extract fine quality oil from uxi. This is used for frying fish, making soap or massage oil, or for curing sinusitis*. In addition to providing protein and vitamins sorely lacking in rural Amazonian diets, uxi fruits represent a good source of cash for substantial numbers of farmers, transporters and vendors. Farmers near Belém who intensively manage uxi trees, along with other fruit trees and palms, can earn up to 20 per cent of their annual income from selling uxi fruit.

While farmers earn about US\$ 0.13 per kilogramme for the fresh fruit, the retail prices vary from three to 16 times this amount depending on the sales venue. At the famous Ver-oPeso outdoor market in Belém, frozen pulp is sold for around US\$2.60 per kilogramme. The collective sales add up: in Belém in 2003, the sale of uxi fruit generated the equivalent of over US\$ 1 million in revenue.

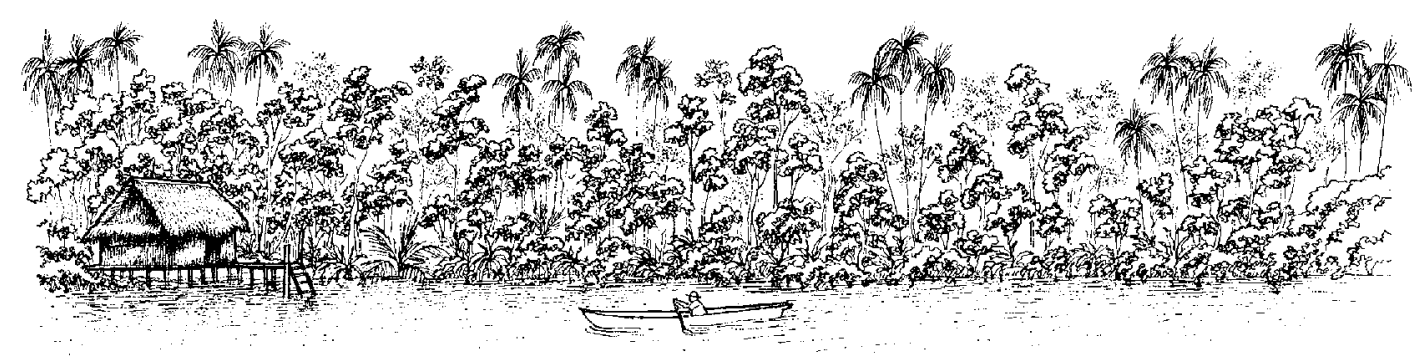




\section{Logging wild fruit trees}

Besides producing nutritious fruit, uxi trees also provide a high quality source of wood, which is sought after by the timber industry. However, the thin bark of these trees and their inability to resprout after being burnt make them vulnerable to the effects of repeated logging and fire. Over a nine year period marked by eight consecutive timber harvesting events, 19 out of 24 uxi trees monitored in one area died due to a combination of logging, agriculture, wind and fire. After the logging, families were consuming on average, 70 per cent less fruit. Rural households can ill afford the loss of such a cheap, accessible and rich source of vitamins and protein.

Unaware of the shorter and longer-term consequences for their livelihoods, and with few other options to earn cash, families often sell off the timber rights to their forests for sums of less than US\$ 2 per tree. Projects which assist forest communities to recognise the value of fruit, medicinal oil and game-attracting tree species, can help rural families to weigh the costs and benefits of logging, and to conserve species of high value to their families' welfare. Uxi is the only species within its genus" and is unique to the Amazon basin. Given uxi's nutritious fruit, healing bark and protective seeds, farmers with first-hand knowledge of this "poor man's fruit" merit greater appreciation and attention.

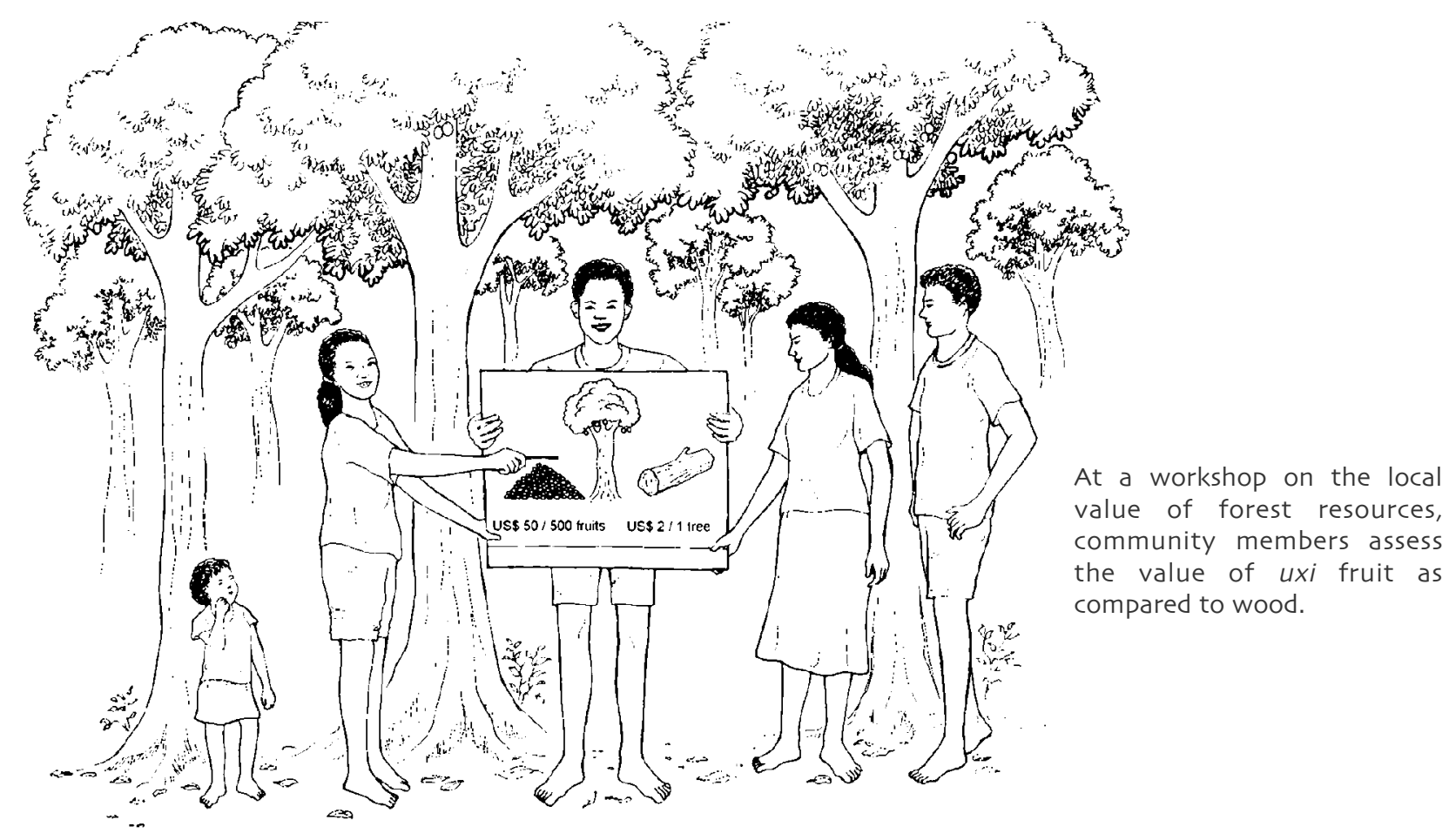




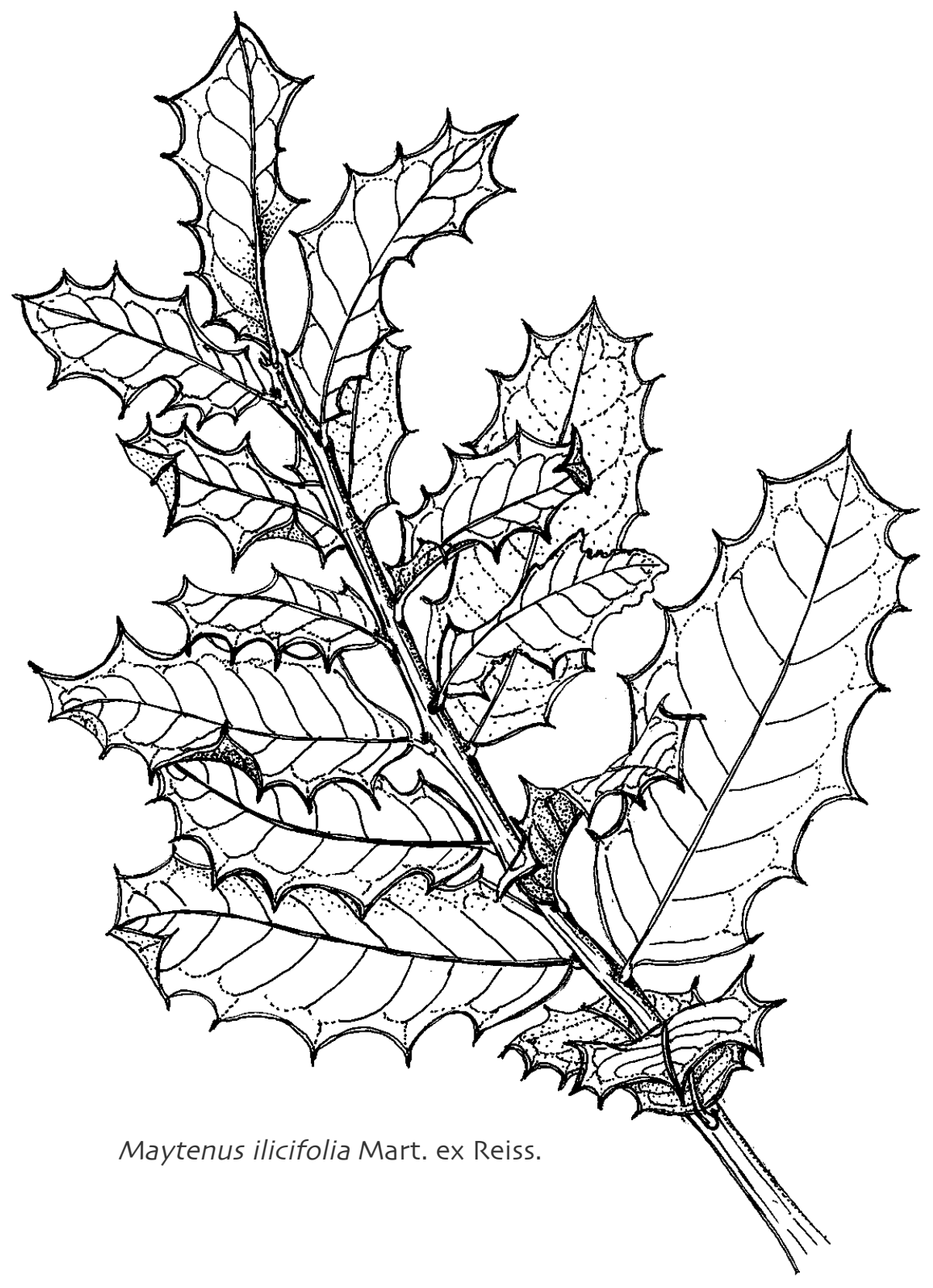

Espinheira-santa, medicinal leaves Brazilian case by Marianne C. Scheffer 


\section{Espinheira-santa: A traditional remedy finds modern markets}

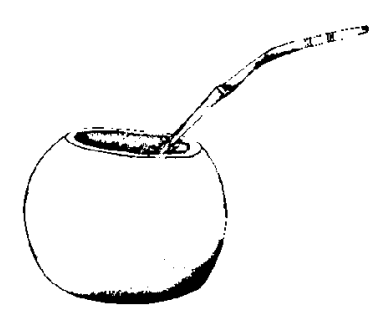

Long before Europeans arrived in Brazil, maté was a beverage that the Guarani Indian's drank, served in a vessel made out of a plant gourd* (cuia).

"God is the best doctor, and nature is the best pharmacy", says a phrase on the wall of a Brazilian farmers' co-operative. No other statement better conveys the link between local people and natural resources in Brazil, especially in relation to plant products traditionally used as remedies. Espinheira-santa (Maytenus ilicifolia) is a testament to nature's healing properties, with extracts from the leaves being used as an analgesic (pain-reliever), tonic, disinfectant, and as a treatment for gastric ulcers and the healing of scars.

The local names of medicinal plants often reflect their importance to people who live far from the ease of drug stores, or whose incomes fall short of purchasing synthetic medicines. For example, guess where the name espinheira-santa comes from? Espinheira literally means 'spiny', referring to the thorns that grow along the sides of the leaves. Santa, meaning 'holy' in Portuguese, is attributed to the plant's healing powers and reflects the devotion that people have for this plant.

The therapeutic powers of espinheira-santa, and many other plants, are well known to people in southern Brazil. Such knowledge was a gift from the Guarani Indians, the region's pre-Columbian inhabitants. In recent times, the medicinal properties of espinheira-santa have become recognised abroad as well, and the plant has become known and appreciated in many parts of the world.

Espinheira-santa is an attractive shrub that grows naturally in the understorey* of the Araucaria forests*, and in the grasslands* of southern Brazil, Paraguay, Uruguay and Argentina. Each orange fruit that it bears contains one to four small seeds covered with white mucilage*. Birds like to eat this fruit, dispersing the seeds and guaranteeing regeneration of the species.

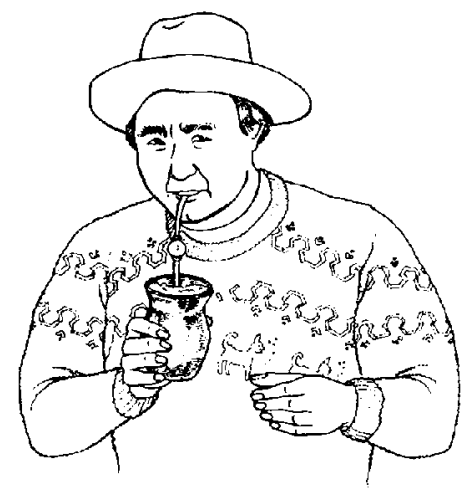

Today, maté is as popular as ever, but it is now drunk from a silver vessel, using a special straw that filters out the tea leaves.

\section{A powerful healing tea}

The leaves are often mixed with the caffeine-rich leaves of the erva-mate tree (llex paraguariensis). The resulting tea, called maté, is one that the Guarani Indians have enjoyed for centuries. Today, in the south of Brazil, it is more popular than coffee, and some people drink it all day long. So, the overall amount of espinheira-santa being consumed can be very high. 
Espinheira-santa leaves are known to prevent and cure stomach diseases, especially gastric ulcers. More recently, they have also been shown to be effective in the treatment of certain types of cancer. International sales of espinheira-santa to countries like Japan and the United States of America experienced a boom in the 1980 s, shortly after a series of studies documented the plant's medicinal values. Throughout the 1990s, the international market for the product stabilised.

\section{Declining wild supplies a catalyst for cultivation}

Around 90 per cent of espinheira-santa leaves are extracted directly from forests. Traditionally, harvesters have collected the leaves during autumn, when the concentration of tannins* is higher and the plant is not flowering or fruiting. Drawing on their local knowledge about managing the species in its natural habitat*, the collectors would break off small branches rather than cutting mature ones (which would reduce the plant's ability to resprout). Also, by collecting the leaves from a plant once every two years, the branches were able to recover, flower and fruit. Such harvesting practices allow for seed production and plant regeneration. Nowadays however, collectors are placing increasing pressure on natural stocks by over-exploiting the plants and disregarding the time necessary for them to recover from harvesting.

In addition, deforestation in the region, due to factors like agricultural and urban expansion, is contributing to the decline in the genetic diversity* and availability of this species. Wild stocks are becoming more scarce, yet demand for the product is continuing to rise. This combination of factors has led some farmers and state extension programmes to plant espinheira-santa seedlings in the region's forests. Local farmers are also being encouraged to cultivate espinheira-santa in open fields, while research institutes have begun investigating cultivation techniques as a means to meet the future demand for raw

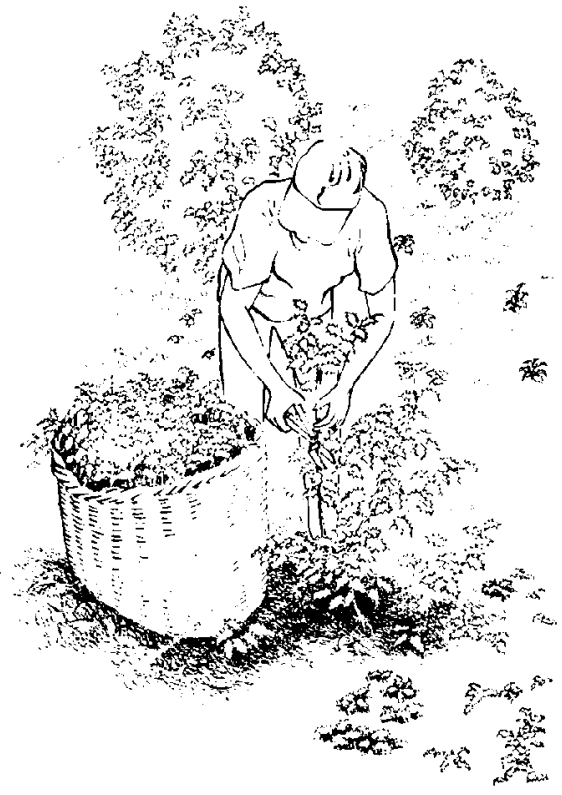

Espinheira-santa leaves are generally collected by men. Some harvesters gather only espinheira-santa while others collect various types of medicinal and food plants. material.

Plantations currently produce 10 per cent of the espinheira-santa harvested for sale. These plantations reduce pressure on wild plants and produce better quality leaves, with less fungal contamination. Leaf prices reflect the difference in quality between the wild and cultivated supplies. Dried leaves from forest stocks are sold for around US\$ 1.50 per kilogramme, while plantation leaves fetch up to US\$ 6 per kilogramme. 
In the marketplace, espinheira-santa is sold as chopped leaves or in mixtures of herbs, teas and tinctures. Some pharmaceutical companies in Brazil are also using extracts from the plant to produce medicines, mainly to treat gastrointestinal disorders. The espinheira-santa products have been sold in markets, supermarkets and drug stores in Brazilian cities and abroad, and have also become available via the internet.

\section{Growing commercial demand}

In the past when you wanted to buy espinheira-santa to prepare as a tea or medicine, you had only to visit your local supermarket. However, after the results of studies investigating the therapeutic properties of this plant were published in 1988, the regulating agency (ANVISA) reclassified espinheira-santa as a medicinal product, rather than a food. Therefore, legally espinheira-santa can only be commercialised as a medicine and sold in drugstores. However, it can still sometimes be found as a food product (as a tea or mixture of herbs) in other places, sold without the accompanying therapeutic information.

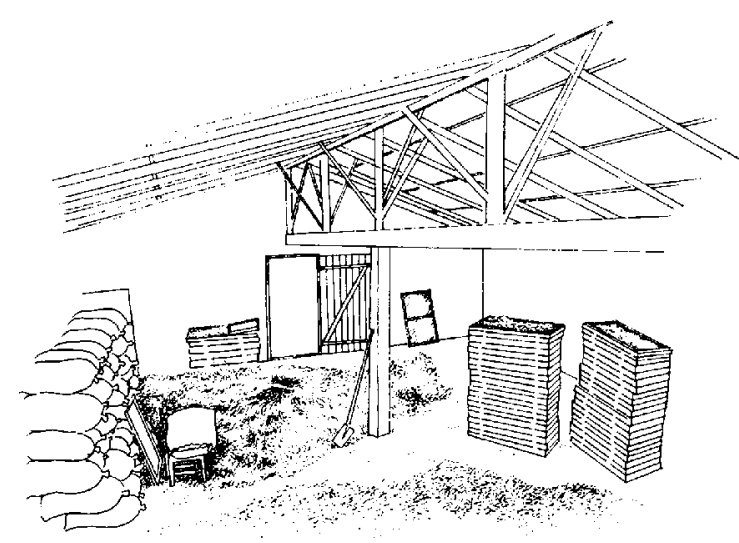

In good climatic conditions the harvested leaves are dried in two or three days, in preparation for sale.

Nevertheless, in many cases, consumers are now confined to purchasing the leaves and medicinal preparations only from drug stores. This reduction in access for the general public to a fairly cheap, effective product may restrict some of the traditional uses of espinheira-santa among Brazilians.

Due to its long tradition of usage and the recent growth in the number of uses and users which has resulted in new and additional products - the demand for espinheira-santa is on the rise again. This is reflected in a recent study in Paraná, on medicinal species registered by ANVISA, and the associated investments farmers are making to cultivate such species. Because the majority of the leaf supply is still extracted from the wild however, natural populations of espinheira-santa are likely to continue to decline.

Programmes to establish and expand plantations may take some pressure off natural populations. Although, the environmental and social impacts of such programmes will need to be evaluated. For example, landless collectors who gather espinheira-santa from the wild are among those who most depend on the economic benefits from sales. Such traditional collectors, without their own land or access to technical information about cultivation, will remain shut out of the economic opportunities associated with plantations of this important medicinal species. So, fostering sustainable wild harvesting and exploring other income generating avenues will need to be part of the overall management plan for this species and its traditional collectors. 


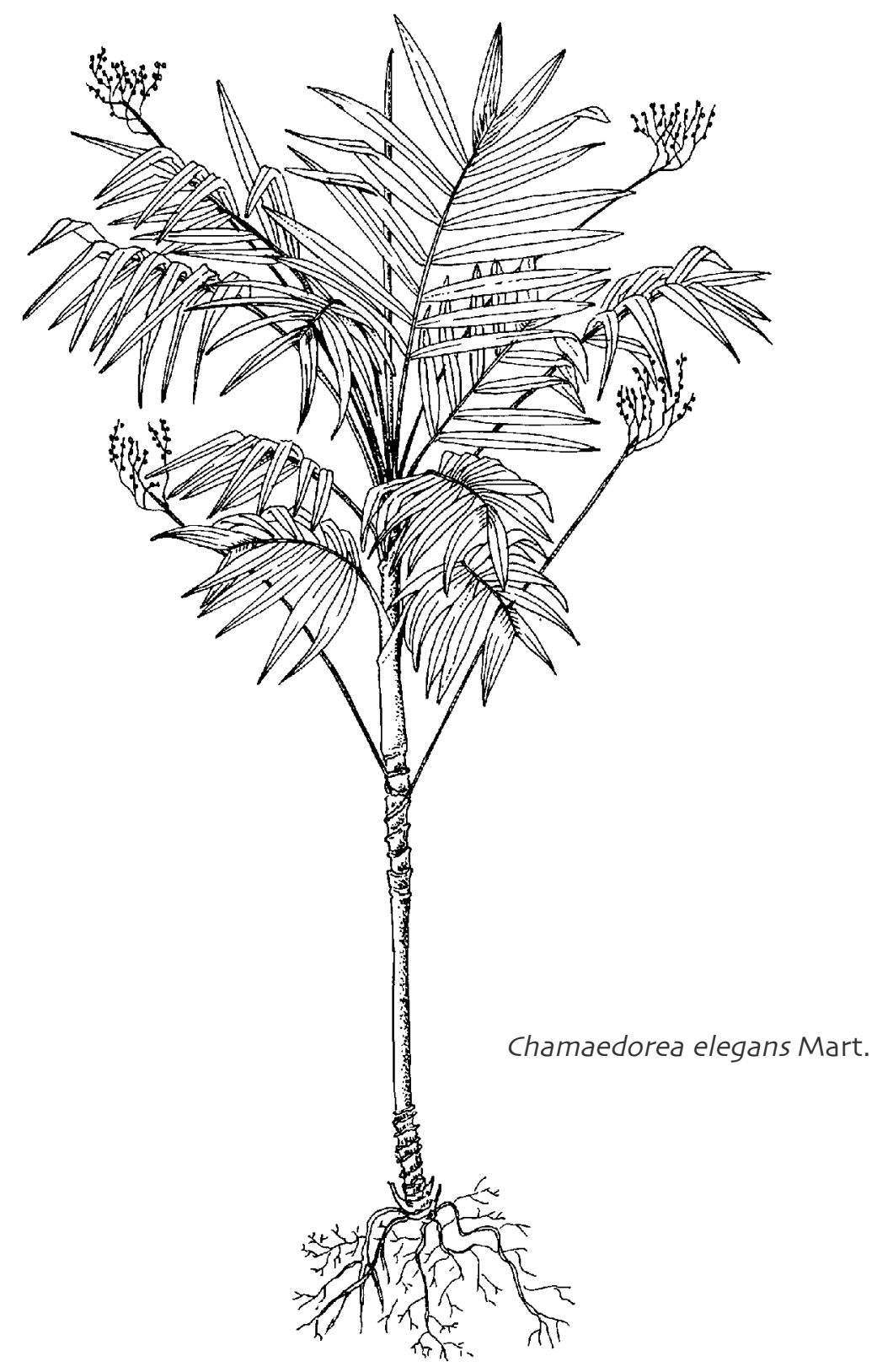

\section{Camedor palm}

ornamental plant, decorative leaves

Mexican case by César Carrillo Trueba 


\section{Camedor palm: Bouquets of elegance}

Since the nineteenth century, potted camedor palms (Chamaedorea elegans Mart.) have adorned homes, and in recent times a new market has also opened up for the palm fronds" - in flower bouquets. Palma camedor or palma xate as it is known in

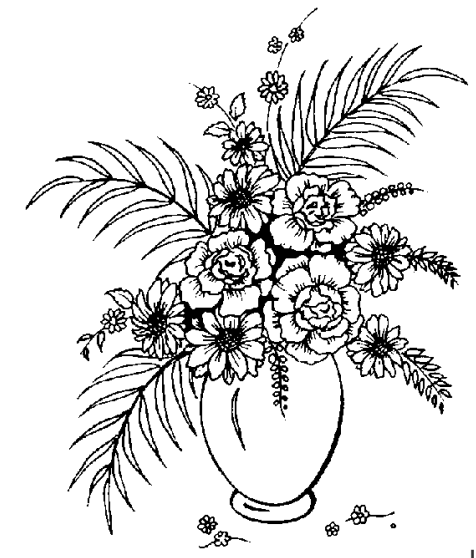

Mexico, can grow up to $2 \mathrm{~m}$ high, with long thin stems and relatively short fronds of around $30 \mathrm{~cm}$ in length. The attractive cut leaves stay fresh for up to a month, making them useful to florists worldwide.

The popularity of ornamental plants bloomed in Europe during the Victorian era when it became fashionable to decorate homes with exotic plants. Chamaedorea species were among the most popular, and were well known in the United Kingdom due to their ability to tolerate low light and maintain continuously green foliage*. By the end of the nineteenth century, camedor palm seeds and seedlings could be found for sale in many plant nurseries throughout Europe. The cut fronds began to be used in floral bouquets in the 1940s, when an American cut flower retailer discovered the leaves in Mexico and began to export them. Since then, indigenous* Mexican communities have been harvesting the leaves for export (along with some other plants of the same genus*, mainly C. tepejilote, C. concolor and C. oblongata), principally to the United States of America, but also to Europe and Japan.

\section{Palms in the forest}

Palma camedor can be found in the underbrush of humid forests in Mexico and parts of Central America. It grows in rocky and well-drained soils with abundant organic matter*. In undisturbed forest, up to 6,000 palms can be found growing per hectare. As the plant only grows naturally in mature old-growth forest*, never in secondary forest*, the presence of camedor palms indicates a relatively well conserved ecosystem*. Seeds take close to nine months to germinate* and each year the plants grow a little more than $5 \mathrm{~cm}$, producing around four leaves and up to six inflorescences (or clusters of flowers). As far as we know, plants growing in the wild do not live more than 20 years, but ornamental plants can live much longer.

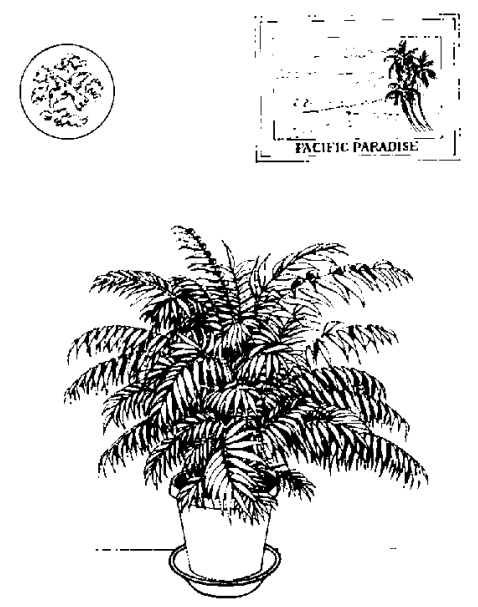

The beautiful green camedor palms are used to decorate the interiors of city apartments and houses. 


\section{Harvesting the leaves and seeds}

Harvesters often work in pairs or small groups. They begin by exploring familiar forests and then move on to new areas. When a harvester arrives at a site with an abundant palm patch, he may cut up to 15 gruesas (bundles consisting of 144 palm fronds). If the palms are less abundant, the harvesters may only cut four to ten gruesas. Palms can be harvested when they are around four years of age, the time when they also begin to produce seeds. The required commercial length of fronds needs to be taken into account, but care and attention must also be paid to not cut the leaves too low - otherwise the flowers may be left without adequate structural support. Two leaves should always be left on the plant, and new shoots should remain untouched.

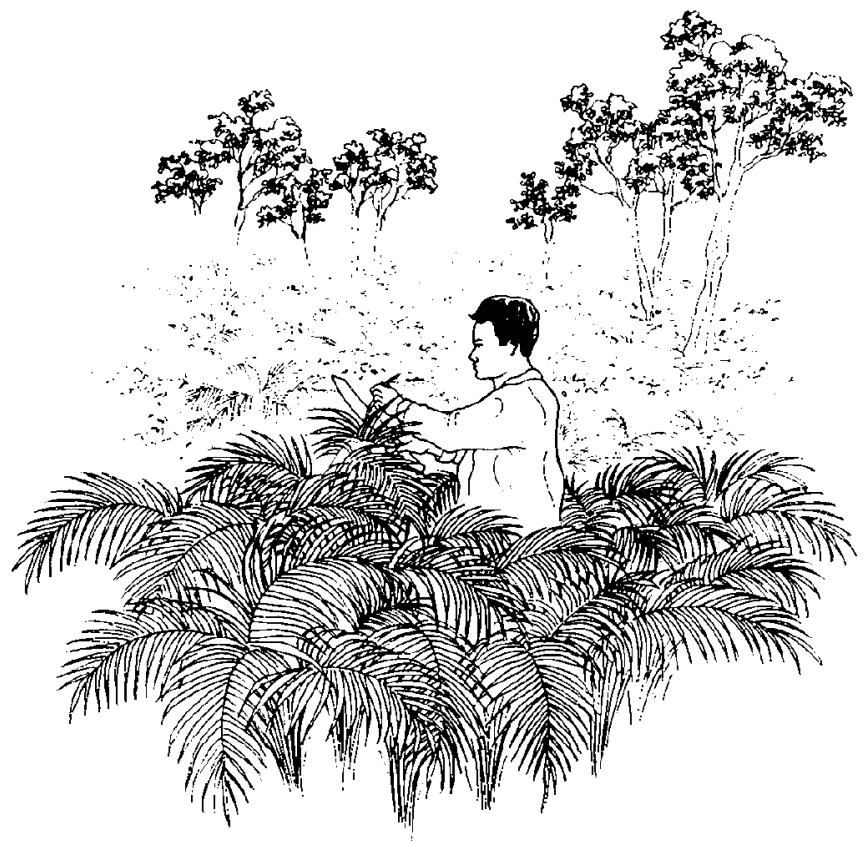

Harvesting can be a risky activity, as snakes are common in the forests where camedor palms grow.

Mexican harvesters are paid US\$ 1 for a gruesa of 144 palm fronds, whereas in the United States, one single frond can cost US\$ 1. A community can extract up to 1,000 gruesas (144,000 leaves) per week. The income obtained may be relatively small, but selling the leaves is not a principal economic activity. Farmers cut camedor leaves as a supplementary job to obtain a little extra money, often during periods of adversity. Therefore, the time they spend harvesting is irregular, varying with the age of the farmers and the level of work required for their milpa* (which represents the main subsistence activity for rural families), and for commercial activities like tending coffee plantations or raising cattle.

In Mexico's Huastec region, the camedor palms are cultivated in plots, and the seeds are collected in addition to the leaves. Several decades ago, the seeds used to be collected from the wild, but national forestry laws now prohibit this. However, the new law has not stopped the wild seeds being harvested during September to December, when the flowers go to seed. A single plant yields around 150 grammes of seeds, which are sold by the kilogramme (each containing about 5,000 seeds).

\section{The palm abroad}

Harvesters sell the seeds and leaves to local middlemen, who in turn, sell to two large intermediary companies. These companies export the products mainly to the United States, with small quantities also going to Europe and Japan. Demand is so high that the intermediary companies have begun to establish their own plantations in order to boost supplies.

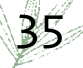


In 1998, Mexico exported approximately 225 million leaves and four million seeds to the United States. The seeds are germinated and cultivated in Florida, and the resulting plants are later sold in various parts of the United States and Europe. In spite of attempts to produce seed in these plantations, the cultivated palm does not successfully fruit, perhaps due to a lack of pollinators*. Artificial pollination* is yet to be carried out. The indigenous Huastec people who gather the seeds in Mexico have a saying: "The natives of Mexico give much joy to God, and for that reason God gives us two products - the leaf and the seed. Where there are gringos*, there is just leaf."

\section{Strong leaves, low prices}

Far from harming the plant, removing some of the fronds can stimulate new growth. Instead of producing four leaves a year, up to six new leaves may grow. The variable degree of harvesting, along with careful management practices explains why, in spite of the great volume of leaves being harvested, the species' population appears to remain stable. In areas where it is diminishing, this is mainly due to habitat* destruction or a decline in the prices of cash crops like coffee - which motivates people to look for other activities to earn money, like harvesting palma camedor leaves. When the harvesting is done without respect for customary guidelines however, this puts pressure on the wild palma camedor populations.

Recognising such threats, several communities are employing collection practices to avoid over-harvesting and protect the palms, while others are cultivating the camedor palms in small plots directly in the underbrush of local forests. However overall, there are presently few economic incentives to conserve the palms. Management efforts by indigenous communities have not been adequately compensated for, as prices have not risen, and there is little attention being paid towards fair trade or ecological certification*. Nevertheless, high international demand, good potential for management and a strong base of local knowledge constitute a good foundation for efforts to manage palma camedor for the future.

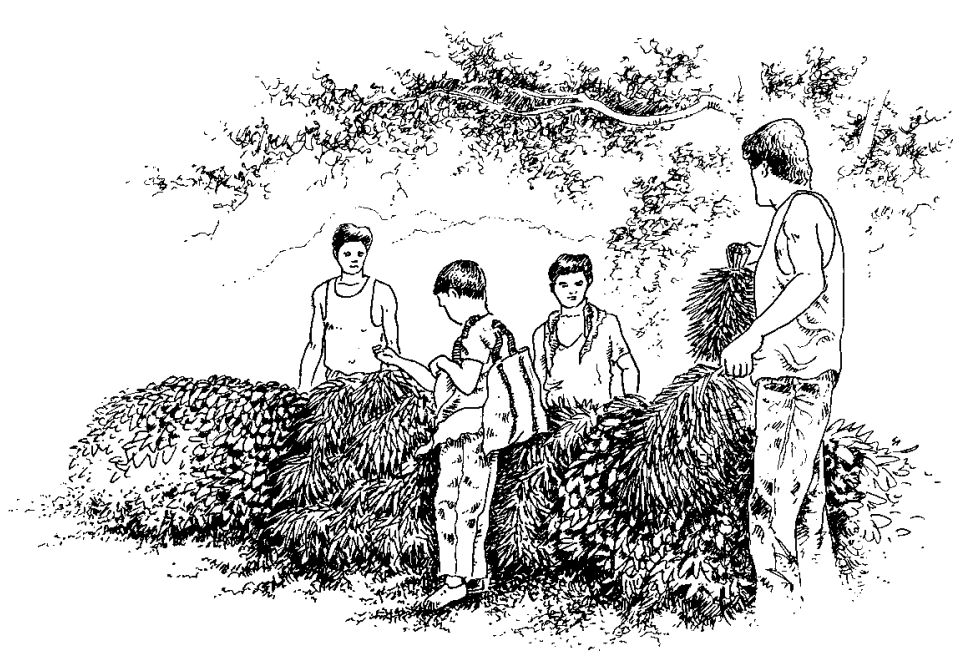

Indigenous communities organise the harvesting and selling of camedor palms collectively, in order to obtain better prices.

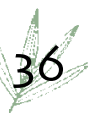




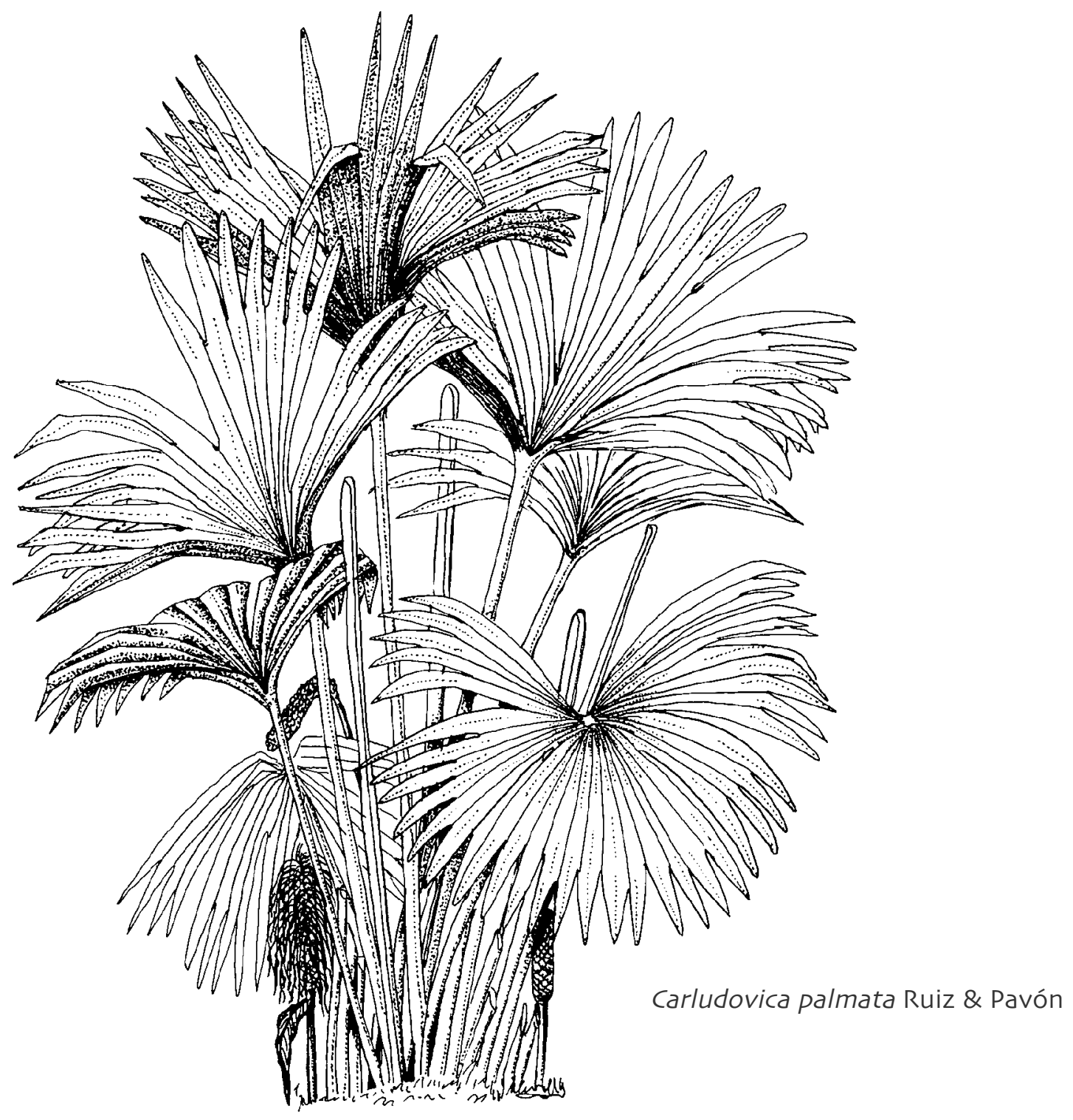

\section{Toquilla fibre, Panama hat}

Ecuadorian case by Rocío Alarcón Gallegos 


\section{Ecuador: Birthplace of the Panama hat}

'Panama hats' are famous the world over as a Central and South American fashion icon, but they actually originated in Ecuador, where they are made from the fibre of

a plant known as toquilla. Indigenous" people living in Ecuador's Pacific area have been using this fibre for around 4,000 years, and even with the coming of the Spanish conquistadores", the new mestizo" people continued their weaving of the fibre to make distinctive headware. Over the last two centuries, toquilla has been used to produce the finest hand-made hats in the world - the Panama hat known locally as sombrero paja toquilla.

\section{A palm that is not a palm}

Toquilla (Carludovica palmata) is a perennial* plant that grows in tropical and sub-tropical areas, from Mexico and Panama to Brazil. It is known by different names in different countries - as jipi japa in Bolivia (see the next case in this volume), where it is used in the production of a variety of woven items, as palma jipi in Mexico, iraca in Colombia, and junco in Honduras. The plants look like small palms, but unlike true palms their stems do not emerge directly from the ground. Instead, the leaves sprout from the base of the plant.

Toquilla grows in clumps of 40 to 300 mature individuals, and can be found in forests and agricultural fields. Originally, the raw material for making the fibres was collected from wild plants, and the species is no longer abundant in places where it was once heavily harvested. Nowadays, about 90 per cent of the fibre comes from cultivated supplies. In the Manabi Province for example, where most of the natural forests have disappeared, toquilla is grown on agicultural land and in small toquilla plantations called pajales, established more than a century ago in response to the commercial demand at that time.

In addition to its hat-making role, toquilla leaves are frequently used to thatch the roofs of houses, kitchens and animal shelters, while the fibres from the leaf stalks are used to make cords and binding materials. Indigenous groups in Amazonia have found different medicinal uses for the plant parts too, such as applying the chewed shoots and stems to cuts to prevent infections. The plants have also been used as an economic and symbolic gift. Traditionally, sons would inherit not only land from their fathers, but also some clumps of toquilla or pajales, as a symbol of financial security for a safe future. 


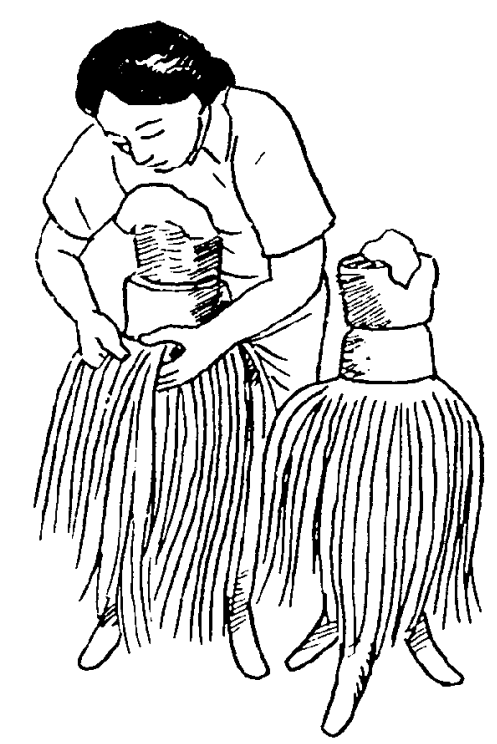

Female artisans stand as they weave, bending forward at the waist and leaning up against round, wooden blocks.

\section{The history and trade of the hat}

The weaving technique for Panama hats is very old, as is the practice of men wearing the distinctive white, wide-brimmed hats to protect themselves from the sun. The trading of hats however, only began during the colonial period. From the sixteenth to eighteenth centuries, the hats were highly valued items, worn only by the elite. By 1810, Panama hats had become the most important product traded from Ecuador to Spain. The king of Spain, Carlos IV, is even known to have given one to Napoleon Bonaparte as a gift.

Throughout the 1800 s and 1900s, the demand and production of Panama hats continued to increase. In South and Central America the hats were very popular. They became part of the uniforms of the Panama Canal workers, the military in Ecuador's Cuenca region, and militants fighting for liberty in Cuba. However, the bulk of the hats were exported to Europe through Panama - hence their mistaken identity.

By the time production peaked in the nineteenth century, about 88,000 inhabitants of Cuenca were involved in making hats. Export figures topped half a million per year at one point, making the hats the second most important export after cacao. Demand began to drop as the twentieth century dawned, especially as a result of competition from cheaper Asian substitutes. Production has stabilised in recent decades though, due to the growing market for natural fibres and handmade traditional or indigenous products, appreciated by consumers in Brazil, Europe and the United States.

\section{Women weave at dawn and dusk}

In villages throughout the Manabi Province, men and women share the work of producing hats. The men search for suitably aged plants with central leaf shoots yet to open, and harvest these shoots with a machete. At home the women extract the fibres - a painstaking and timeconsuming activity. They remove the outer leaf protecting the shoot and separate the individual leaflets on the stalk into fibres. These are boiled and bleached with sulphur before being hung out to dry.

Panama hats are made from very finely woven fibres, reflecting centuries of local knowledge passed down through generations. Weaving is undertaken early in the morning or at night when humidity is high and the

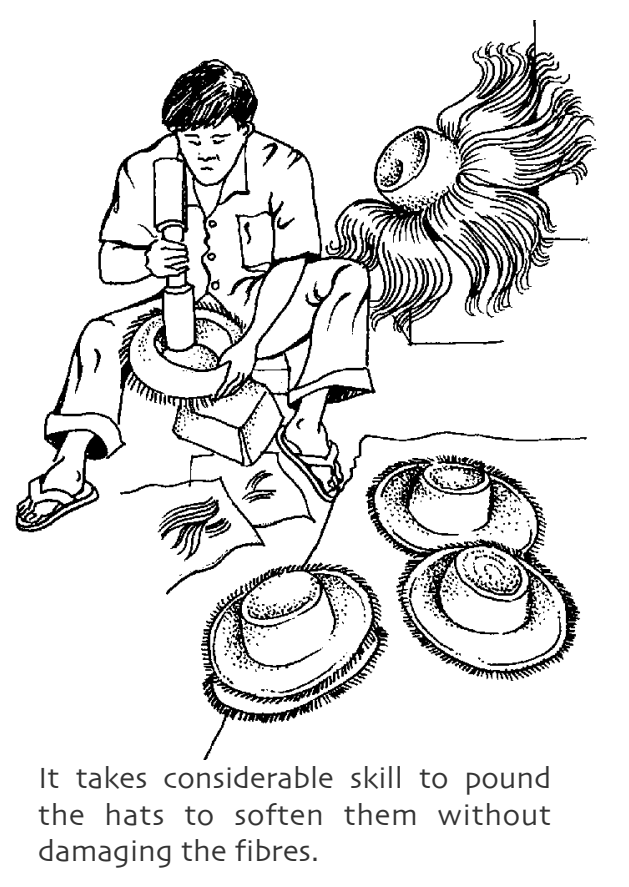




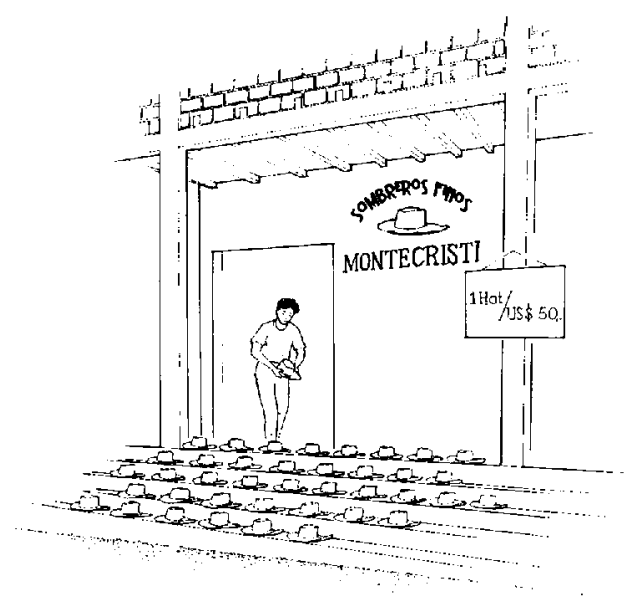

Panama hats are sold in small stores in the Manabí Province of the Andes, the heartland of hat production, for around US\$ 50 each.

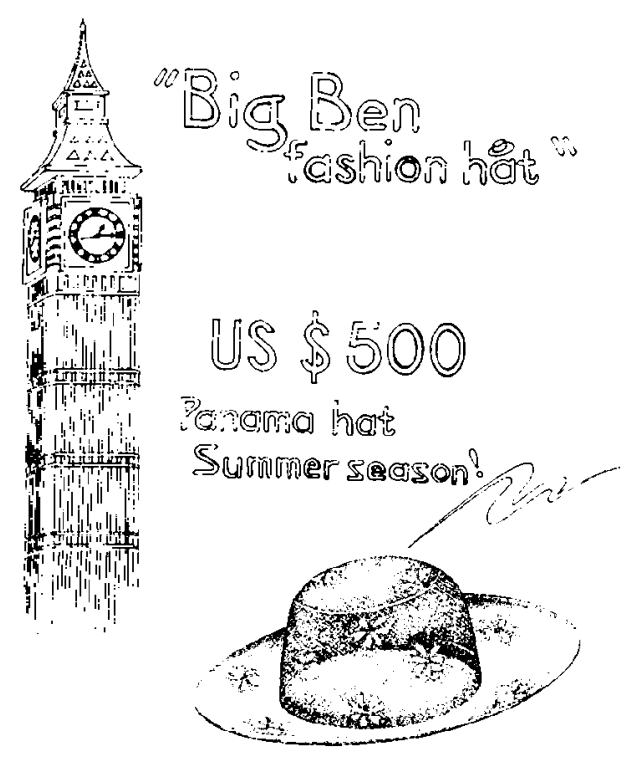

Exported to countries like England, Panama hats have become fashionable, highly priced items. fibres are most flexible. Women weave for about six hours a day, standing up as they work as this enables them to create a finer weave. It takes about three months or 540 hours to manufacture a single, top quality hat. Different types are produced, with the finest ones being so flexible they can bend without breaking the fibres.

The woven hats are finished by specialists, who take the long straws still hanging around the edges and weave these into a strong band, trimming any loose ends. The hats are then pounded with special hardwood" mallets to soften the straw and finally, are ironed to create a smooth, lustrous appearance.

Some artisans buy fibres rather than cutting or processing toquilla themselves. Bundles of 96 leaves sell for about US\$ 1.20. Workers are paid US\$2.00 to strip and dry the bundles, with the prepared leaves then being worth around US\$3.85. Semi-finished hats require approximately 24 leaves each, and are sold locally to dealers for around US\$ 15. The dealers either finish the shaping and grading steps themselves or hire specialists. The finished hats sell in the local markets for as little as US\$ 50, but in Europe or the United States the highest quality hats can demand US\$ 500 .

\section{The fall of the Panama hat?}

Hat weaving has been a traditional activity for centuries and in Ecuador's Manabí Province it is the only source of income for many women. Despite their world-wide reputation and the high prices that Panama hats command, the returns to farmers and artisans are low. This is leading some toquilla harvesters and hat producers to find alternative ways to earn a living.

Over time, the quality of hats has been declining. Whereas the hat of one's grandfather could be folded up smaller than a golf ball, today's hats are coarser and less flexible. Fewer women have the patience and fortitude to wake up before dawn and weave again at dusk, and some young women have started to migrate, looking for less demanding, more lucrative jobs outside their villages. If prices remain low, farmers may start cultivating other agricultural products instead of toquilla plants. Such issues will need to be addressed to safeguard the future of Ecuador's famous headwear. 


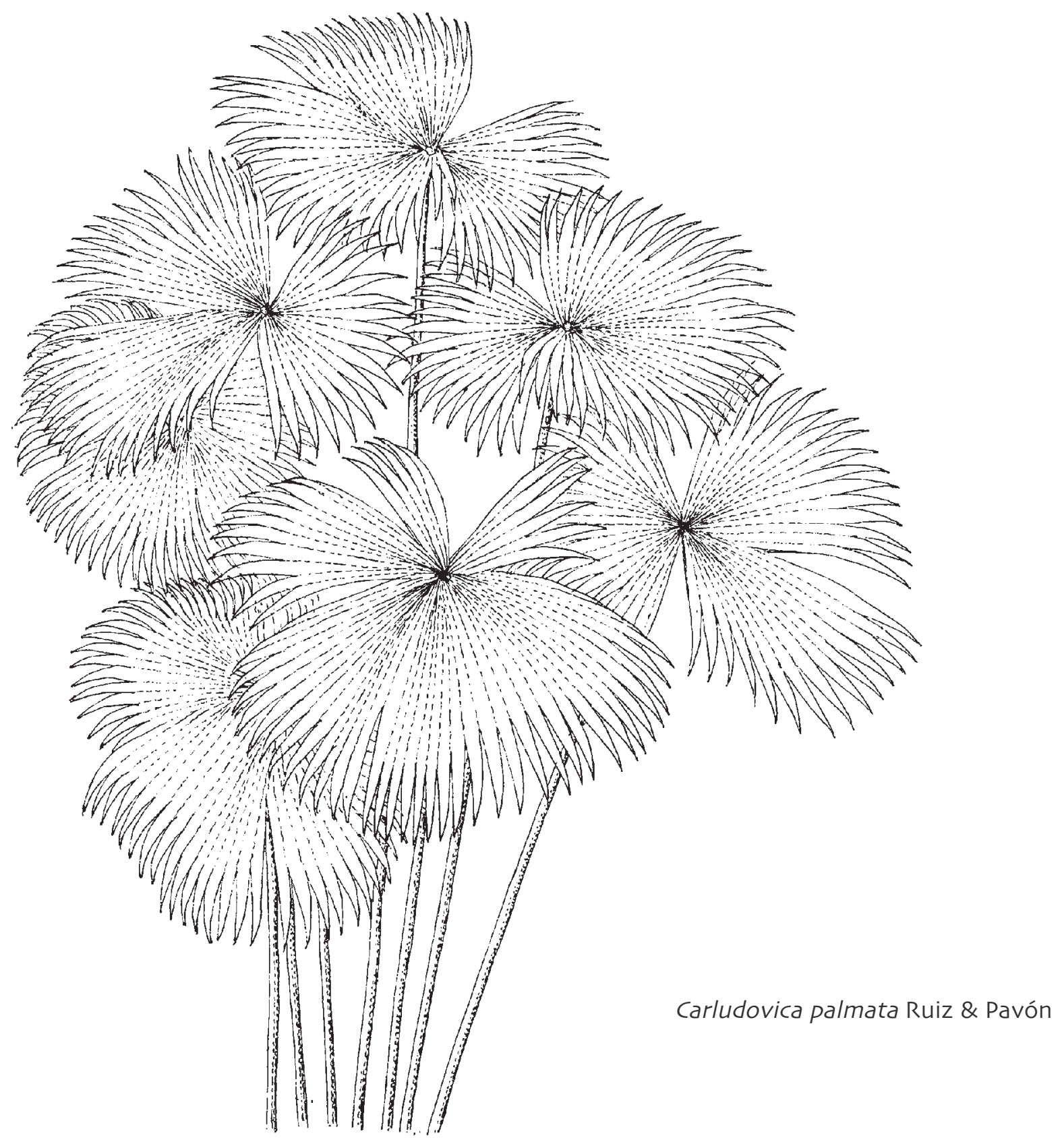

\section{Jipi japa fibre, handicrafts}

Bolivian case by Erik Arancibia and Fausto López 


\section{Bolivia takes its hat off to jipi japa}

Jipi japa, a palm-like species that grows wild in tropical and sub-tropical forests in Central and South America, has woven itself deep into the everyday lives of Bolivian villagers. A wide array of goods is produced from its fine, white fibres - including the famous Panama hat (see the previous case in this volume).

The Panama hat originated in Ecuador, gaining its name from the trade route to Europe, which passed through Panama. Jesuit missionaries introduced the weaving techniques used to make hats and baskets into Bolivia in 1908. It was a worthwhile initiative. By 1911, the Norwegian explorer Erland Nordenskiold observed an improvement in the quality and design of hats coming out of Bolivia. Over time, the artisans expanded their skills in processing and handling jipi japa fibres to include the manufacturing of wallets, portfolios, decorative figures, purses, and various utensils for kitchens and tables.

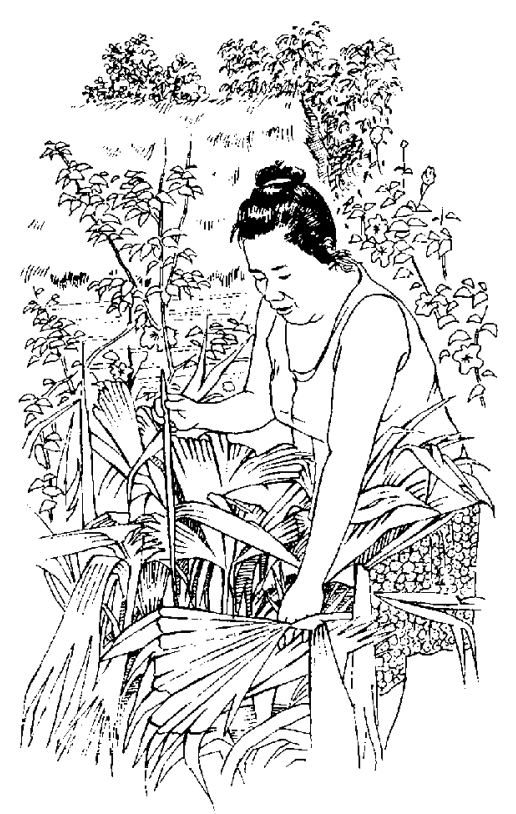

A woman harvests unopened jipi japa shoots from the base of the stem. Once processed, the fibres are woven into hats, baskets and many other useful items.

\section{Community work}

Today, jipi japa handicrafts are manufactured in the lowland communities of north-east Bolivia. They are made by indigenous* people in the towns of Buenavista in Santa Cruz and San Borja in Beni, and also by settlers in Buenavista, and in Chapare in Cochabamba. These remote communities are developing stronger relationships with the outside world as their manufacturing of jipi japa handicrafts expands.

As a result, some artisans are forming collectives to assist the commercialisation process. The main organisations include the Association of Palm Weavers of Ichilo, the Carmen Surutú organisation, and the Asociación de artesanos de Galilea (ARTEGAL). The Association of Palm Weavers has received technical assistance from the Bolivian Government, which supported the introduction of jipi japa plantations through its Centro de Investigación de Agricultura Tropical (CIAT). Carmen Surutú and ARTEGAL are women's associations which produce jipi japa handicrafts. ARTEGAL was developed with the help of the Beni Biological Research Center but Carmen Surutú lacks outside support and relies on local markets to distribute its wares. The jipi japa weavers are supported by the Asociación de Artesanos del Campo (ARTECAMPO), a non-governmental organisation which assists with the manufacturing of textiles and other crafts, and provides different market channels within Bolivia. 


\section{Harvesting the shoots}

Jipi japa plants (Carludovica palmata) grow in humid tropical and sub-tropical forests, but they can also be found growing wild in agricultural fields, on communal lands, along the banks of rivers and in ravines. jipi japa is generally harvested from wild stocks. The species is rarely cultivated in Bolivia as villagers have had limited success due to the low survival rates of the plants. They tried growing them in the direct sun in monoculture* plantations but many of the plants dehydrated due to a lack of shade. Some of the plants managed to grow but their leaves were much smaller than those of the wild plants that grow under the shade of the forest canopy*. The Ecuadorians however, have had more success with cultivating jipi japa, known as toquilla in that country, and have managed to establish productive plantations of this palm-like plant.

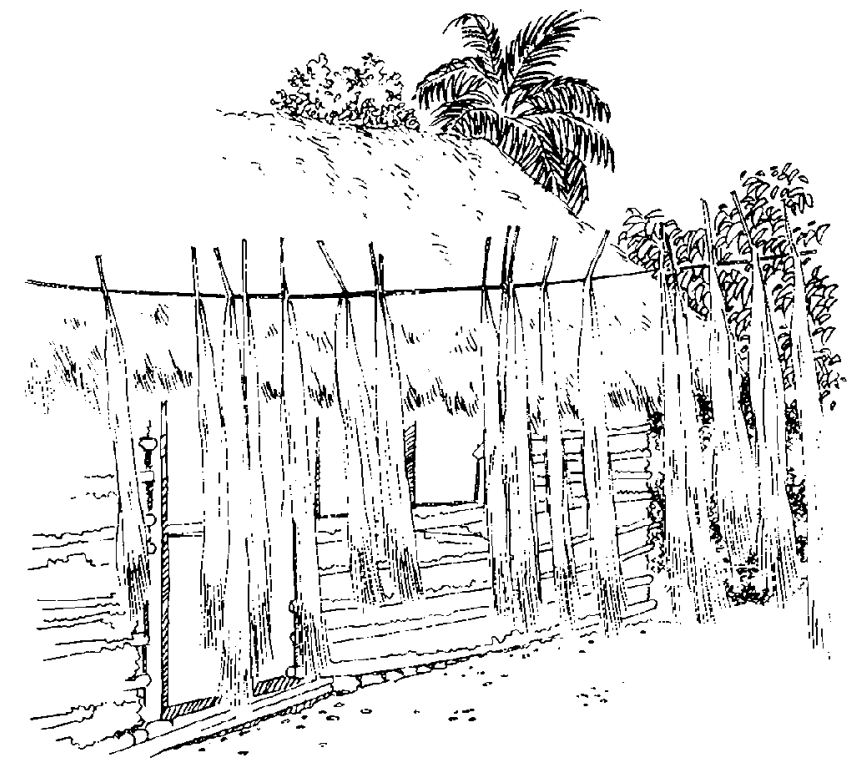

The fibres are hung out in the sun for a couple of days, turning from yellow to white as they dry.

\section{Many steps to perfection}

There are several steps involved in the processing of jipi japa fibres. The harvesters, who are mainly men, cut the shoots (known as cogollo in Spanish) in the field or in the forest, and return with them in bundles to their villages. Each bundle weighs between two to three kilogrammes and contains 12 to 14 closed leaves. The length of the leaves varies but most are around $1 \mathrm{~m}$ long. Two to three of the hard outer leaf layers are stripped away from the thickest part of the shoot and discarded, as they are unsuitable for weaving. A wooden compass, thin bone or needle is used to peel these layers off.

The shoot is then split in half, and the thin and narrow leaf layers are removed, leaving the wider ones for weaving. These are boiled for 10 minutes in a large pot of water containing lemon juice and lavandina (a commercial bleach). They are then hung out in the sun for about 20 minutes before the fibres are separated from each other. The fibres are left hanging outside overnight and throughout the following day to ensure that they dry completely. They turn from yellow to white, at which point they are ready for weaving. Recently, some artisans have begun dyeing the fibres using five different colours. They then combine these coloured fibres during the weaving process to great effect. 
In some cases the jipi japa harvesters also carry out the weaving. In other cases they sell the fibres to artisans who produce the various handicrafts. In San Borja in Beni for example, it is common for the harvesters to also weave, whereas in Buenavista in Santa Cruz, where there are about 20 families producing jipi japa handicrafts, only two of these families also harvest the shoots - largely due to the long distances required to reach the forests where the plant grows.

Most of the jipi japa handicrafts are sold within Bolivia, although the artisans' association in Chapare, in Cochabamba, has been exploring the export market. It is difficult to estimate the total value of jipi japa production since the raw material is incorporated into many different products, which are commercialised in many different ways. At the household level, jipi japa can represent anywhere between 15 and 80 per cent of total family income. The factors influencing this include the distance to market, the number of people in the family involved in the jipi japa trade, and whether or not they belong to one of the associations.

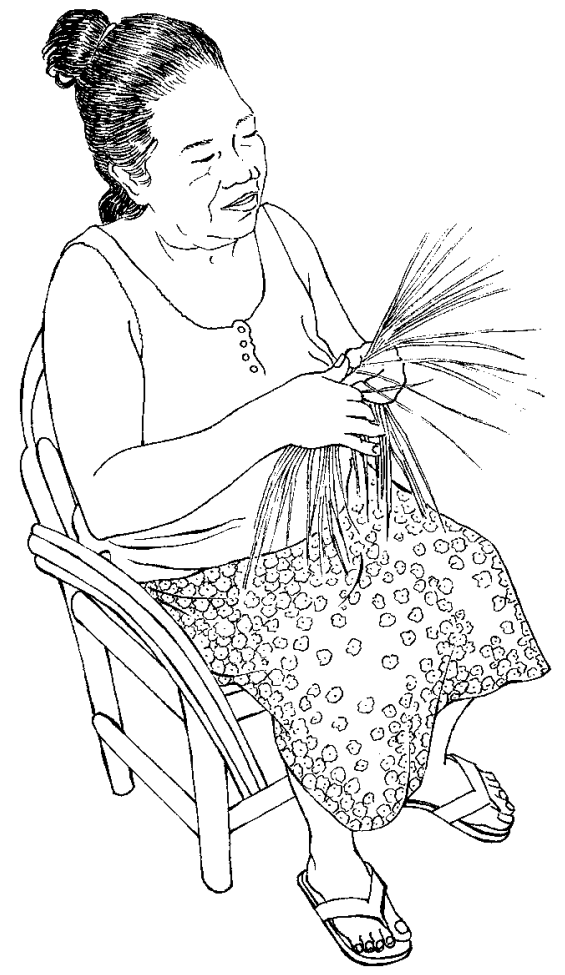

A woman starts to weave the dry jipi japa fibres into another new handicraft.

\section{An uncertain future}

There are two main negative factors affecting the production of jipi japa handicrafts. In some areas, jipi japa shoots are being harvested faster than the plants can regenerate, reducing Bolivia's wild populations of this plant. Where over-exploitation is occurring, too many shoots are being removed - shoots that would normally go on to become leaves - decreasing the amount of photosynthesis* occurring in the plant, and reducing its capacity to recover. Almost half of the original Bolivian jipi japa population has already disappeared, largely due to changing land use patterns. Forest land is being felled and converted into pasture for agriculture and cattle ranching.

Another threat comes with the incorporation of new associations being set up with government or foreign support. Building up the capacity to promote the production of jipi japa handicrafts without ensuring there is an adequate consumer demand can result in a saturated market and lower prices for harvesters and processors. Such factors will need to be taken into account to ensure that jipi japa populations can survive in Bolivia and continue to provide benefits for the adept harvesters and weavers who work with this plam-like plant.

This publication is an output from a research project funded by the United Kingdom Department for International Development (DFID) for the benefit of developing countries. The views expressed are not necessarily those of DFID. R7925 Forestry Research Programme.

\section{4}




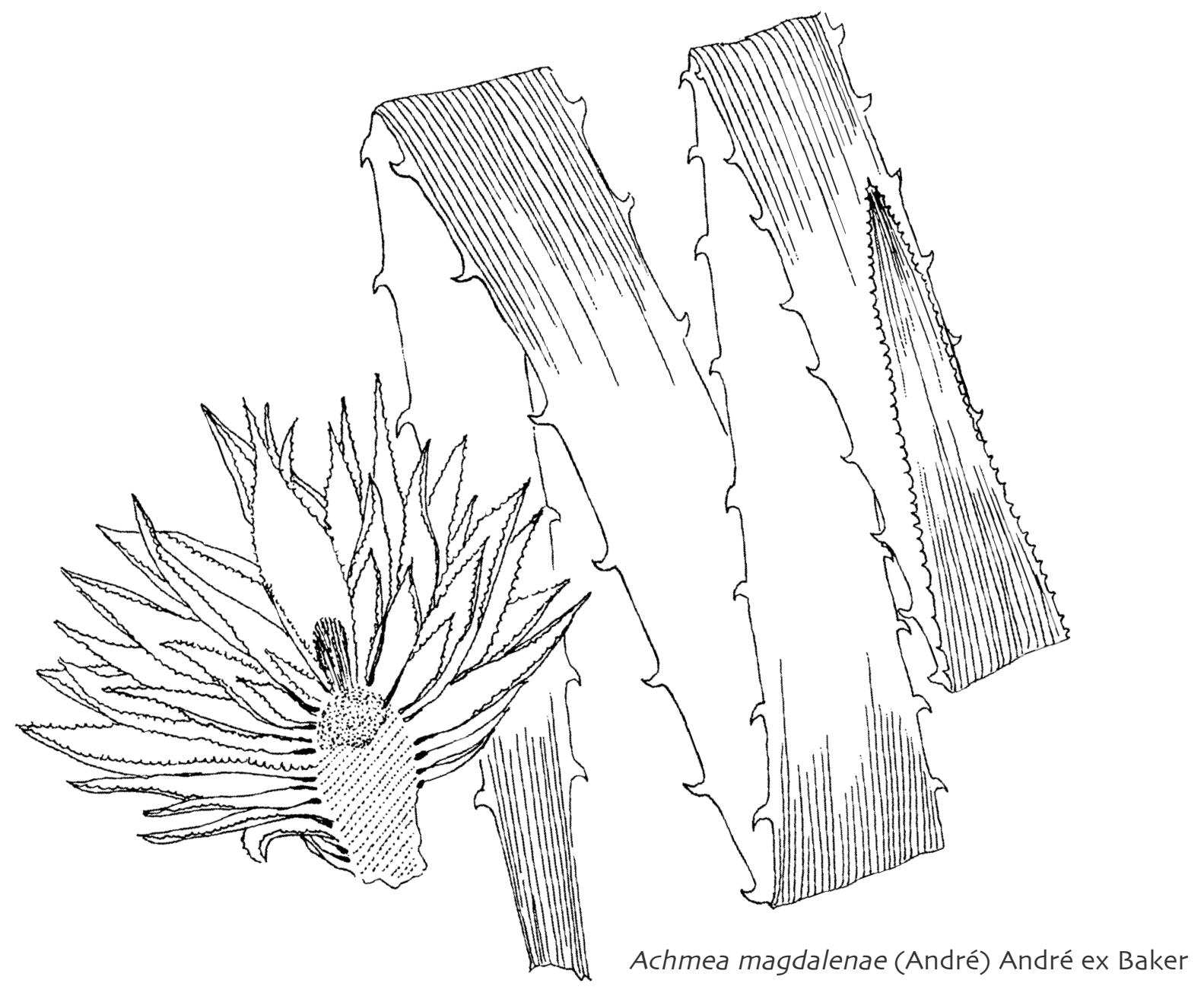

\section{Pita fibre, embroidery}

Mexican case by Fabrice Edouard 


\section{Musical movement triggers revival of pita - the world's most resistant natural fibre}

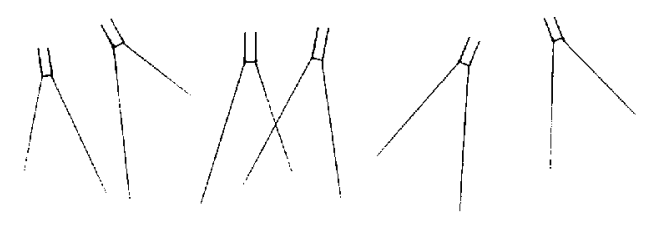

A cultural and musical revival along the border of Mexico and the United States of America has ensured that a vital thread connecting the past and present remains unbroken. The centuries old art of using 'pita fibra' - a plant fibre as bright and smooth as silk but stronger and more versatile - had been in danger of dying out. Its

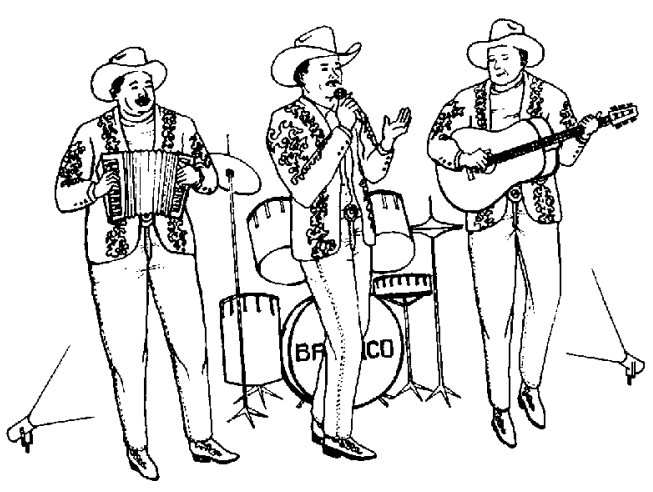

Grupera dance music is performed by small bands that play accordion and bass, wearing beautiful clothing and accessories adorned with pita embroidery. saviour was the emergence of a fashionable musical phenomenon called Onda Grupera. Reminiscent of the days of the Charro (Mexican cowboys), the musicians wear beautiful embroidered leather piteada garments - previously the attire of cowboys alone. This musical phenomenon has turned pita, once spurned in favour of synthetics, into the nation's most valuable and desirable natural fibre.

\section{From fish nets to fashion}

The pita plant (Achmea magdalenae), also known as ixtle, grows naturally in the high tropical forests of south-eastern Mexico. The fibre extracted from pita's thorny leaves (which can grow as long as $3 \mathrm{~m}$ ) is exceptional in many ways. It is comparable to silk in terms of its size, brightness and fine texture but it has greater strength and resistance. Traditionally, the Chinantecos, Lacandones and Popolucas indigenous* groups used it for making fishing gear as it did not shrink or lose resistance in water. Dyed with indigo, it was woven to make longlasting fishing nets that were nearly invisible under water. Pita fibre was also used to moor the ends of arrows and make ceremonial objects like fans of pheasant feathers.

From the 1960s onwards however, the boom in synthetic fibres resulted in a sharp decline in pita use. Nevertheless, in the north of Mexico, saddlers and tack craftsmen continued to specialise in piteada handicrafts, using the fibre to embroider leather goods such as belts and boots. When the musical style of Onda Grupera became popular, the cowboy-inspired embroidered coats, hats, belts and boots found favour with a much broader market. Due to this cultural and musical revival, the demand for pita has increased dramatically, and so has its price - surpassing that of linen and silk and reaching as much as US\$ 100 per kilogramme. 


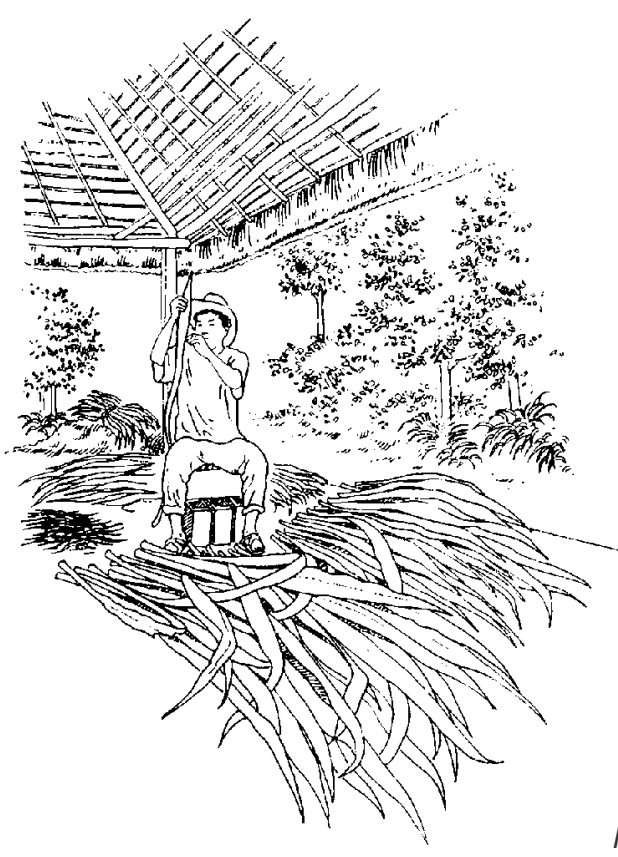

Pita mainly grows in three states in south-eastern Mexico: in the Chinantla region of Oaxaca, the Lacandona forest in Chiapas, and in diverse and small areas of Veracruz, where patches of forest remain. Pita can also be found growing in Central America and Colombia, but these wild populations have not yet been exploited for fibre. The plants grow in dense patches in evergreen* forests, mainly near streams, rivers or flooded areas. Once the plants reach six years of age, they produce beautiful, edible flowers and then seeds before dying.

\section{More profitable than coffee and cattle}

Prior to the 1990s, indigenous and mestizo* communities extracted A harvester removes the thorny edges of the leaves, in preparation for the women to extract the fibres.

pita fibra from wild plant populations. The sudden increase in demand (along with the drop in coffee prices, which resulted in a search for alternative economic activities) encouraged farmers to start domesticating pita by collecting shoots and cultivating them in fallow* plots or acahuales*, coffee plantations and forest patches. Leaves are harvested from plants around three years of age, generally by men. The harvesters gather up to 250 leaves at a time, depending on whether they have animals to transport the load. To obtain $1 \mathrm{~kg}$ of fibre, roughly 250 to 350 leaves (depending on their size) are required. One hectare of forest can yield 15 to $25 \mathrm{~kg}$ of fibre per year, worth between US\$ 430-930. This income is superior to what coffee or cattle producers can earn from the same size of land. Generating such robust income, pita has become very important in south-eastern Mexico, where it is playing a significant role in the conservation of forest patches and acahuales threatened by the expansion of cattle ranches and agriculture. The estimated annual production of pita in Mexico oscillates between 30 to 40 tonnes.

Pita fibre is extracted using an indigenous technique - scraping the leaves on a wooden trunk using a blade made from the stem of a palm. The fibres are then washed several times with soap and lemon juice, before being brushed to remove impurities, and dried in the sun. At this point, the clean white fibres are meticulously combed and classified according to size. Processing $10 \mathrm{~kg}$ of fibre requires two or three people and takes around 15 days. Saddlers turn the fibres into thread by twisting sections of fibre together around their knees. Afterwards they hand-embroider pieces of leather with pre-Hispanic fret designs, producing goods like belts, saddles, boots and portfolios.

The pita leaves are scraped against a wooden trunk to separate out the fibres. 


\section{The craft of saddlers and prisoners}

Indigenous harvesters in south-eastern Mexico sell the raw pita to retailers, who further process the fibre themselves. Acquiring it at a price of US\$28-38 per kilogramme, they resell it whitened and combed to craftsmen and saddlers in the north of Mexico for US\$ 5575 per kilogramme. Though a great number of pita craftsmen exist, the greatest concentration is found in the small city of Colotlan in the state of Jalisco. In Colotlan, highly developed artisan companies hire more than 1000 embroiderers. Prisoners in Mexican jails also produce many of the items bought by music fans.

Pita crafts have a high market price, with some piteada belts being sold for more than US\$ 280, and quality, hand-embroidered saddles for more than US\$ 900. From the 1990s onwards, craftsmen have also been producing a less costly line of products, generating sales to a growing number of consumers in Mexico, the United States and more recently, Spain. Today, the organisation of pita growers and traders is allowing regional groups of harvesters and saddlers to directly commercialise and sell their products. Regulating councils have been formed to handle collective fibre supplies and handicraft labels.

\section{Pita fibre for paper money}

Demand for pita grew considerably in the 1990s, but craftsmen are noticing the market has declined slightly in the face of competition from hand-made crafts based on ostrich leather and other exotic skins. Nevertheless, the use and marketing of piteada belts is now well established in Mexico and amongst expatriate populations in the United States. The Mexican Government, producer organisations and non-government organisations are currently working together to identify new opportunities and uses for pita fibre. The Bank of Mexico for example, has agreed to test the fibre's suitability for making paper money more durable. Such initiatives can help to secure the future for this versatile and valuable fibre and the people who harvest and process it.

This publication includes outputs from research projects wholly or partly funded by the United Kingdom Department for International Development (DFID) for the benefit of developing countries. The views expressed are not necessarily those of DFID. R7925 Forestry Research Programme.

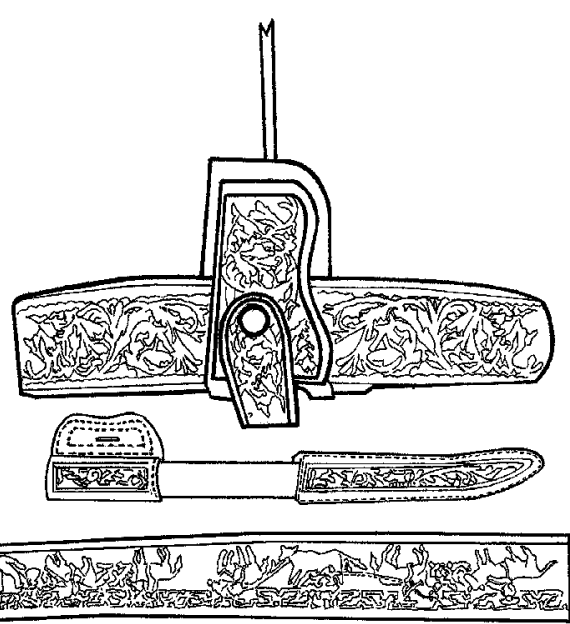

Mexico's Charro (cowboys) have traditionally worn garments emboidered with pita fibre. 


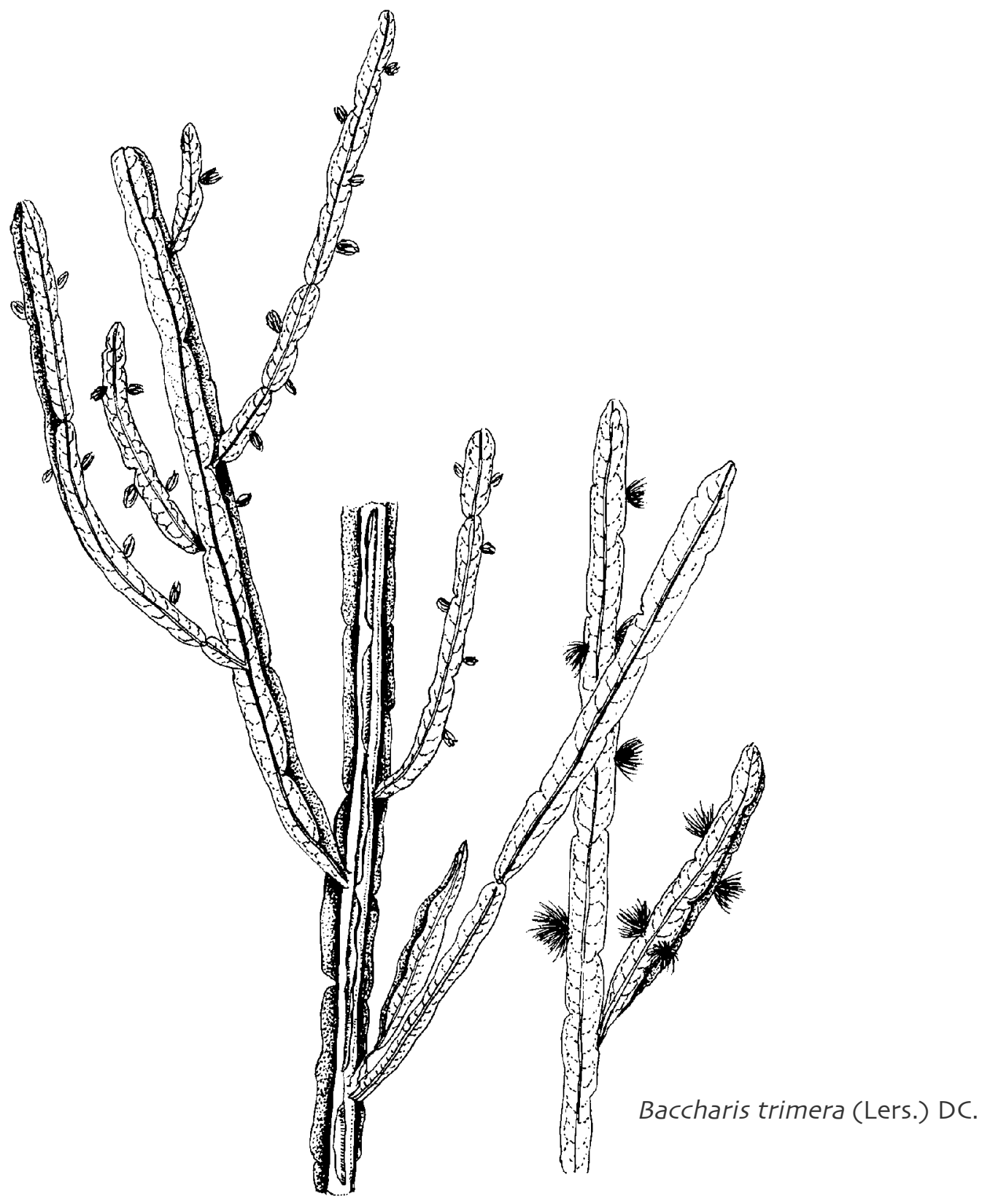

\section{Carqueja, medicinal leaves}

Brazilian case by Walter Steenbock 


\section{Carqueja: Herbal healing from the Brazilian high plains}

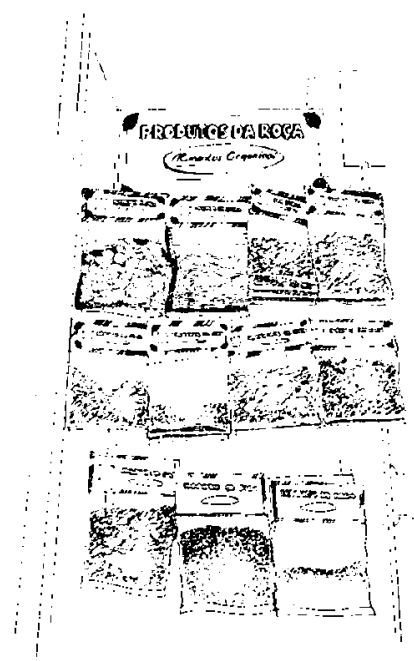

Different herbal products, including carqueja, are produced by a cooperative in Banhado Grande, central Paraná, under the label Produtos da Rosa.

The southern Brazilian plateau is an enchantingly beautiful place, with its mix of majestic Araucaria forests* and native grasslands. The forest borrows its name from the Brazilian pine (Araucaria angustifolia), a tree with an impressive height and trunk diameter, and a crown* that has a distinctive architecture all its own. But the plateau is remarkable for more than its rugged, beautiful landscape - it also sustains a diverse range of hardy plant species, several of which have medicinal qualities that are proving valuable for local rural communities.

The soil and environmental conditions in this region are somewhat harsh so commercial agriculture is quite limited. In many of the local communities, the collection of non-timber forest products (including Brazilian pine nuts, mate tea leaves and medicinal plants) has become an important economic activity. Among the medicinal plants, one of the main species being harvested is carqueja (Baccharis trimera), a herb popularly used in the treatment of digestion problems and obesity.

The use of carqueja has been studied in the central region of Paraná, a state in southern Brazil, where this plant is quite abundant. Local inhabitants include a rich cultural blend of indigenous* people, caboclos" and the descendants of Italian, German and Polish settlers. This cultural richness is reflected in the large number of medicinal plants that are used, and over the centuries, local people have developed a considerable base of knowledge relating to the therapeutic properties of these plants.

\section{From small beginnings - women lead the way}

In the 1980s, groups of women associated with rural organisations in central Paraná arranged a series of meetings to discuss the role of local medicinal plants in treating diseases. They exchanged ideas and recipes, and shared their knowledge about using such plants as alternative therapies. The women soon recognised that apart from their medicinal value, these plants also represented potential economic opportunities for their families. During the past decade, various projects in central Paraná have aimed to safeguard this traditional knowledge, and to promote the management, cultivation and use of native* plant species.

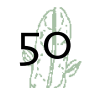


Today, the plant products have become better known and more popular both within and outside Paraná. In addition to treating illnesses, the medicinal plants have assumed a new role in local development, providing a source of income for rural families. New markets have opened up, and plant products from Paraná are now being marketed and sold across Brazil.

\section{The growth of the medicinal tea trade}

Under Brazilian law, medicinal plant products can be classified either under the category of food or medicine. Carqueja has been classified as food, which facilitates its processing and sale by rural farmers. In the community of Banhado Grande in central Paraná, a co-operative was formed following the earlier women's meetings in the 1980s. Working with Fundaşão Rureco, a nongovernmental organisation that provides assistance to agricultural families and associations, the Projeto Florestas

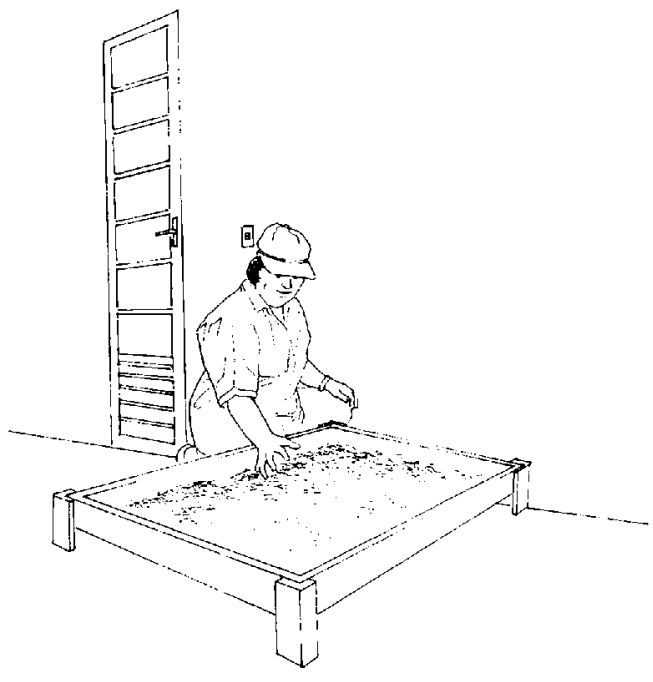

After the carqueja leaves are chopped and dried, they are packed into plastic bags in preparation for sale.

Medicinais was created. This multi-institutional initiative, which has received financial support from the Brazilian government and external organisations, has since expanded to involve similar co-operatives in the region.

For rural families in the communities involved, the production of medicinal plants can represent 30 to 40 per cent of their overall income. In these communities, not only are plants like carqueja being harvested, a selection of medicinal teas are also being produced under the label Produtos da Rosa. These products are being sold in supermarkets, drug stores and markets in Paraná and across Brazil. The production of tea rose from an initial 200 packets per month at the beginning of 1999, to 15,000 packets per month by the end of 2000. Presently, the monthly production is around 25,000 packets, and the demand is continuing to grow steadily.

The herb carqueja is one of the most commercially successful natural remedies in southern Brazil's medicinal plant trade. This small shrub is common to central Paraná, where it grows mainly in the grasslands and on the edges of the Araucaria forests. It can often be found growing in little "islands of carqueja". In addition to harvesting wild stocks, seventeen rural communities are involved in growing and processing carqueja, and other medicinal plants, using organic* techniques. 


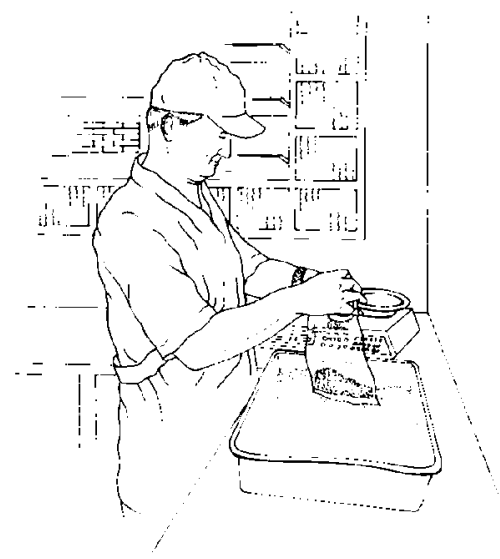

Carqueja and other medicinal plants are sold in local markets, as well as drug stores and supermarkets across Brazil.

\section{Harvesting for the future}

Both men and women harvest and process carqueja. They cut the leaves with a knife or sickle, approximately $5 \mathrm{~cm}$ above ground level. The plant grows quite extensively and can be found at a density of about 1000 plants per hectare. Local farming families generally have around 40 hectares of land each and most of them harvest from their own plots.

As the main collection period for carqueja occurs just before the plants flower, over-harvesting can have a detrimental effect on plant populations, with collection occurring before seeds are produced for regeneration. Since 1999, the Banhado Grande co-operative has been implementing different strategies, based on farmer participation, to safeguard and encourage the regeneration of seedlings. This is helping to maintain a range of plants of different ages, across the collection areas. The experiments carried out during 1999 and 2000 showed that leaving "untouched islands" of carqueja as a form of "seed bank" facilitates regeneration and helps to ensure future supplies - a positive move in the face of growing demand.

Soon after harvesting, the plants are taken to the co-operative, where they are chopped into small pieces and dried. The chopped carqueja is placed onto fabric screens and dried in solardriven, wooden drying chambers. When the level of solar energy drops, an electric heater is used to maintain the temperature at around 35 degrees. Other medicinal plants are also processed using this simple approach. After being dried, the herbs are dispatched to a central facility where they are packed. This central family farmers' association does all its own marketing and selling, bypassing the need for middlemen. As a result, farmers belonging to the associated Projeto Florestas Medicinais receive prices three times higher than carqueja producers elsewhere. Wholesale companies pay other farmers an average of US\$ 0.13 for $1 \mathrm{~kg}$ of dried carqueja, but by cutting out the middlemen, the farmers supplying the co-operative receive around US\$ 0.40 per kilogramme.

\section{Community participation shows the way}

As the demand for medicinal plants continues to grow, one of the challenges for local people in central Paraná is to maintain the sustainable production of organically produced raw material. Another goal is to maintain local control over the production and marketing system. Communities are becoming aware of the key factors that have fostered local development. Farmers recognise that the participation of women, community involvement, the conservation of natural resources, and self-management of the production process are all critical elements of their success. 


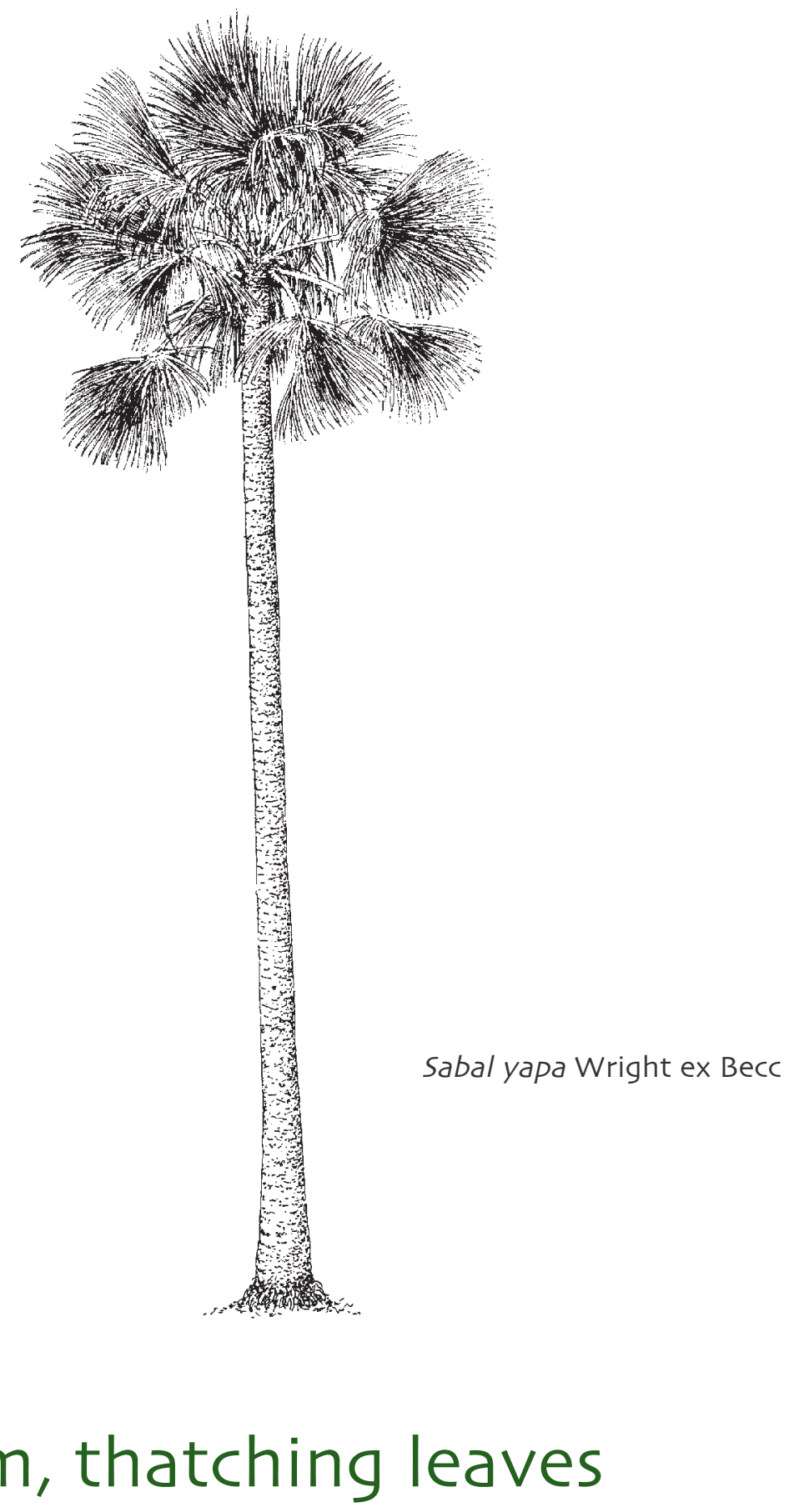

\section{Xa'an palm, thatching leaves}

Mexican case by Javier Caballero, María Teresa Pulido

and Andrea Martinez-Ballesté 


\section{Xa'an palm: Centuries of shade, from the Maya to modern day tourists}

Long before the arrival of the Spanish colonisers, the xa'an palm (Sabal yapa) was integral to the lives of the Mayan people from the state of Quintana Roo, south Mexico. This palm has provided the Maya with food, medicine, fodder and a resilient material for constructing the roofs of their houses. In fact, the thatched roofs built from the large $x a$ 'an palm fronds" or leaves can last more than 15 years. The Mayan name for the palm ( $x a$ 'an) means "the one that gives shade", perhaps alluding not only to the shade that the palms provide, but also the shade from the roofs that are constructed out of the xa'an fronds. Since the 1970s, the same palm that sheltered the ancient Mayan people has been providing shade for tourists lounging in luxury hotels and in rustic huts along the beaches of Cancún, Cozumel, Playa del Carmen and Tulum, in the Mexican Caribbean.

Xa'an palms, also known locally as guano, are common in tropical dry forests and also grow well in areas where the original forest cover has been cut down. The palms are left to grow on land that has been cleared for maize cultivation so that farmers can continue collecting the leaves. Xa'an palms are also encouraged to grow in home gardens and are cultivated in plantations to boost the natural supplies.

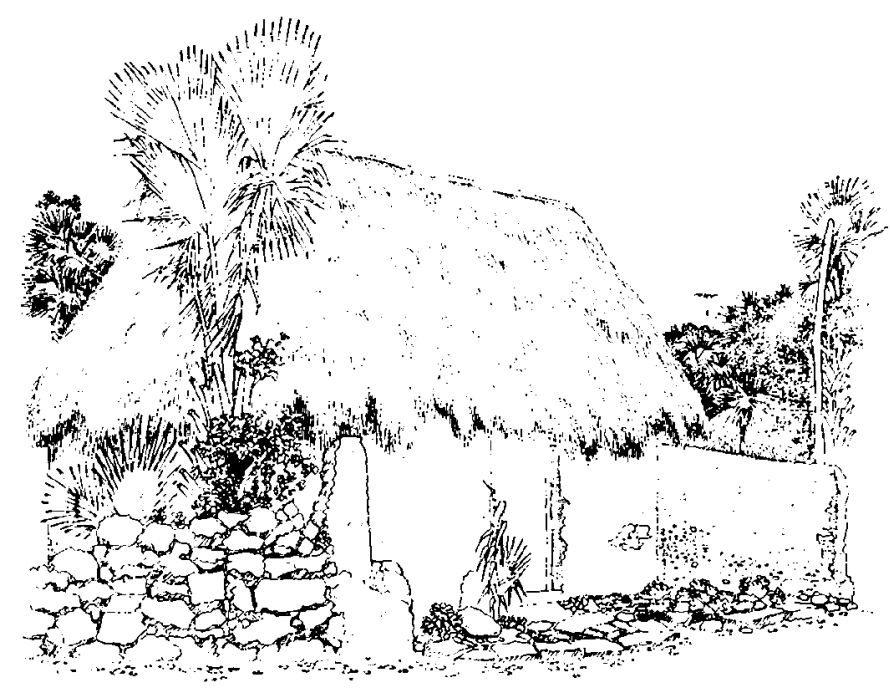

A typical rural home with a thatched roof made of xa'an palm leaves.

\section{Collectors ensure the survival of the palms}

Farmers choose which palms are best to harvest according to their height. They prefer to collect leaves from palms that are around $8 \mathrm{~m}$ high or shorter, as these are less risky to climb than the taller palms, and provide easier access to the leaves. To ensure the survival of the palms, the harvesters collect their bounty thoughtfully. Even after the long, sweaty climb to the top of the palm, they are careful to collect only three to four leaves. Using a machete, they cut the palm frond petiole* as close as possible to the trunk. 


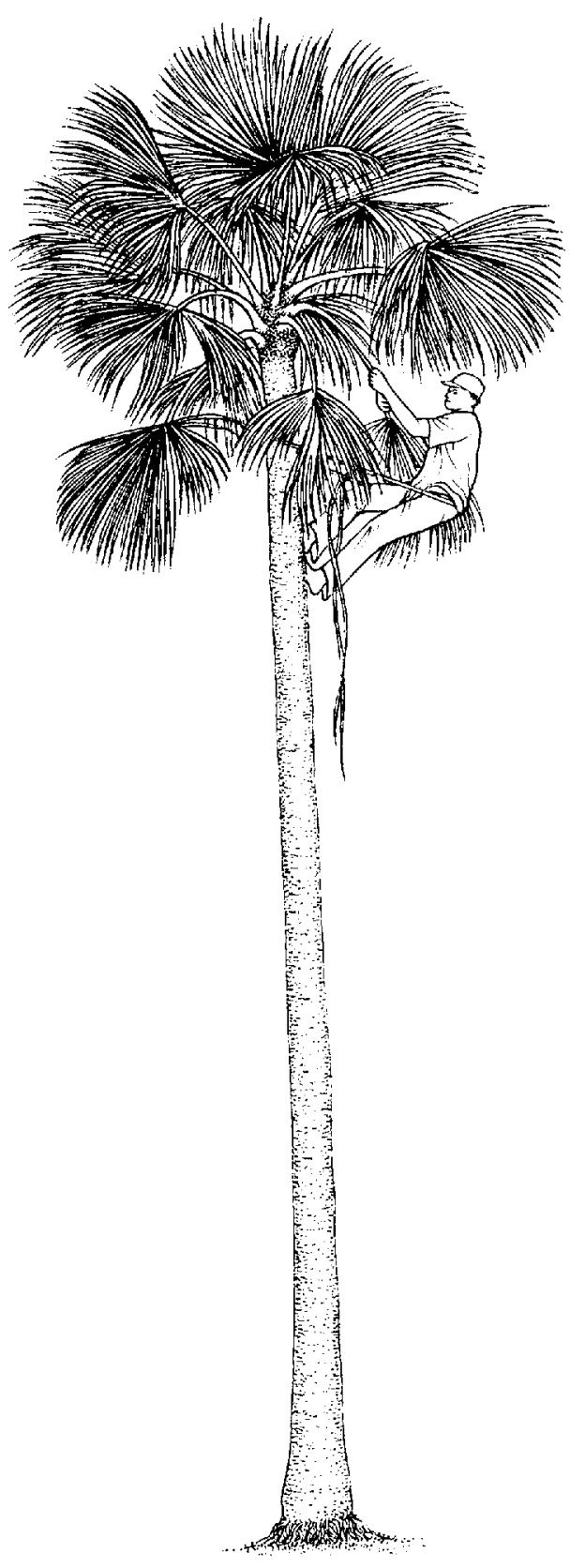

A harvester climbs a xa'an palm, with a rope around his waist, and cuts three to four leaves.
Working hard for a full day, one harvester can cut an average of 200 leaves. When harvesting is done for commercial purposes, the work is carried out in groups of about four to 10 people. After harvesting, the leaves are packed into bundles of 20 to 50, and are carried on the harvesters' backs or atop bicycles to the highway, where transporters or middlemen collect them.

The xa'an palm fronds can be harvested throughout the year. During the dry season the leaves can last up to 5 months before being used for thatching, but during the wet season they need to be dried in the sun and used within five days of harvesting. As a result, collection is usually undertaken during the dry months between February and April, coinciding with a time when farming activities are less demanding and intensive. However, if a retailer asks for leaves, harvesters will collect the palm fronds at any time of the year.

\section{New markets for a traditional resource}

The palm leaves are sold in different ways. Some businessmen buy the leaves directly from the ejidos* and sell them to construction companies working in the tourism business. International luxury hotels and restaurants contract building companies to purchase the leaves and construct the buildings. In some cases, the workers who build the roofs (and who are known as palaperos), go to the ejidos themselves to buy the leaves. Often, they also buy the wooden poles that are needed to build the traditional palm leaf huts or palapas.

The price of the leaves varies according to the cost of transportation and the payment of harvest permits. In the ejidos, collectors are paid approximately US\$ 0.08 per leaf, but the final consumers may buy the leaves for up to three times this amount, at around US\$ 0.25 each.

In the state of Quintana Roo there are about eight ejidos that sell $x a$ 'an leaves. These centres are affiliated with non-governmental organisations that provide technical assistance and co-ordinate the exploitation and commercialisation of the $x a$ 'an leaves. In a single year, an ejidatario* involved in this activity may receive up to US\$ 112 which, although modest, is nonetheless appreciated as it comes at a time of year when crops are not yet ready for harvesting. 


\section{The winds of change}

Like the Mayan people before them, farmers all over the Yucatán Peninsula continue to use $x a$ an leaves to thatch the roofs of their houses. Demand from luxury hotels and the tourism industry however, has recently decreased. In part, this may be due to grass being substituted for $x a$ 'an leaves. Even though it is more laborious to thatch, the contractors like the smooth, 'tropical paradise' appearance of the grass. Palaperos note that the roofs made with grass are more costly in terms of both labour and cash though, and they do not last as long as the xa'an roofs. Presenting another possible reason for the decline in industrial demand, it has become more difficult to obtain xa'an leaves, as farmers have created guidelines to protect the palms for their own use. For example, in X-Maben, ejidatarios decided that from 2001, the commercial harvesting of the leaves would be suspended to prevent exhaustion of the palms.

During the last six years the Mexican government has enacted new environmental laws relating to the management of forest resources, including $x a$ 'an leaves. These regulations are general and implementation is difficult. However, in the case of the xa'an palm, the official guidelines have contributed positively towards regulating harvesting and preventing the over-exploitation of this valuable resource.

Thatched xa'an leaves, traditionally used to shelter the Mayan people, now provide shade for tourists in the Mexican Caribbean. 


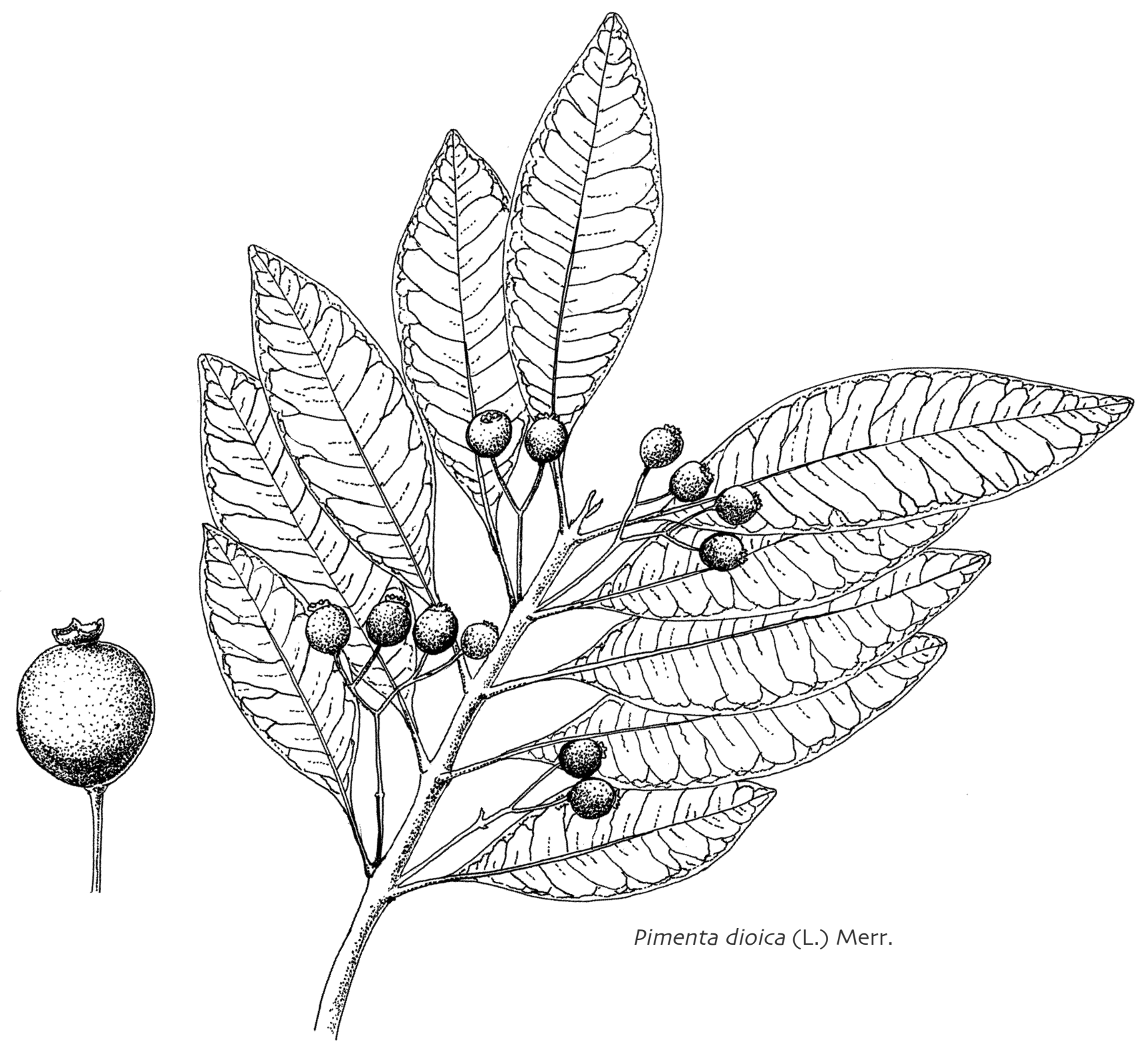

\section{Allspice, pepper seasoning}

Mexican case by Miguel Angel Martinez Alfaro, Virginia Evangelista Oliva, Myrna Mendoza Cruz, Cristina Mapes and Francisco Basurto Peña 


\section{Allspice: The flavour of Mexico}

Do you know where the black speckled seasoning comes from that gives dishes that distinctive sweet, hot peppery flavour and delights people around the world? 'Allspice' is similar to Asia's 'black pepper' but with a sweeter, more aromatic flavour and smell. Sourced from the pepper tree (Pimenta dioica), the flavour comes from the dried, ground fruits, which first appear as small, strongly scented green berries. In addition to the ground seasoning, essential oil is also extracted from the dried berries, for use in the medicinal, cosmetic and food industries.

\section{A long history}

The pepper tree grows in several Central American countries and in Mexico, where its history of use dates back long before the arrival of the Spanish. Known in Mexico as pimienta gorda, the pepper tree has historically given both the Old and New Worlds the tremendous gift of flavour. In pre-Hispanic times, indigenous* people in Mexico used the berries, which they called xocoxóchitl, to season their food, and as an ingredient in traditional medicine. The Spanish colonists quickly adopted the local seasoning and used it in their cooking as well - mixing native condiments, cultivars" and fruits with produce from plant varieties from their homeland. They called the local pepper malagueta or 'tabasco pepper', and it went on to become one of the main commercial products in this new Spanish colony.

During the seventeenth century, the small green berries were commercialised around the world by

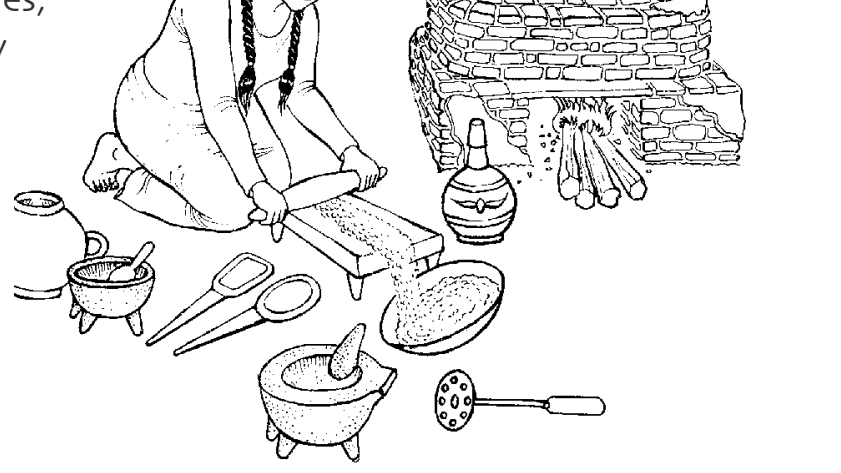

Allspice has been used for seasoning Mexican dishes since pre-Hispanic and Colonial times. Dutch and English entrepreneurs. Since the nineteenth century, the states of Veracruz, Chiapas and Tabasco have been the main allspice producers, joined in more recent times by the states of Oaxaca, Campeche and Puebla. Demand for the dried berries and essential oil is continuing to grow. Between 1990 and 2000, the total Mexican production of allspice increased from 868 to 4,980 tonnes. Most of the production is exported, with only 2.2 per cent being consumed in Mexico. The majority goes to South America, the United States of America, Europe and the Middle East. In 2000, the total export value was US\$ 12.87 million. 


\section{The cultivation of Mexican}

\section{flavour}

Pepper trees that grow to a height of $20 \mathrm{~m}$ are native* to tropical forests in Mexico, Honduras, Guatemala, Belize and Jamaica. They are becoming scarce in the East Mexican forests of the Sierra Norte region, in the state of Puebla though, as rising human populations have led to forests increasingly being cleared for agriculture and cattle ranching. However, escalating international demand for the seasoning has been a catalyst for the cultivation of pepper trees in and around this region and over the past two decades the number of these

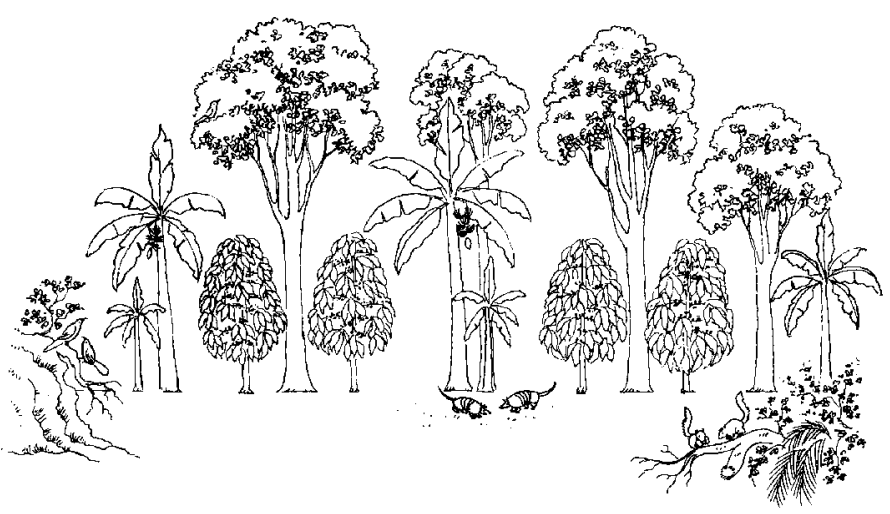

A variety of plants, trees (including pepper trees) and animals grow and live within shade-grown coffee plantations - which resemble the conditions of natural forests. trees has increased twofold.

Pepper trees can be found mainly within the shade-grown coffee plantations" of the Sierra Norte de Puebla, along with other valuable tropical trees, such as mamey, banana, orange, mandarin, cedar, mahogany and jonote trees (which are used for making bark paper - see the amate case in this volume). In the municipality of Tuzamapan, each hectare of coffee plantation contains about 70 to 100 productive pepper trees, which produce up to $120 \mathrm{~kg}$ of green fruit. Each kilogramme sells for around US\$2.20. The pepper trees are valued not just for monetary reasons, but because they also help to improve the soil, with the falling leaves forming a protective layer against erosion in mountainous terrain like that of the Sierra Norte de Puebla.

Within the coffee plantations, a common practice is pruning the branches of nearby trees to promote the yield of the pepper trees. In addition to shade-grown coffee plantations, pepper trees are cultivated in orchards, milpas* (maize plots) and potreros* on small cattle ranches. Farmers also protect the natural regeneration of pepper trees in areas where they are not actively cultivated. When clearing weeds and grasses with machetes, the farmers try not to cut the small pepper seedlings. Some farmers even protect the seedlings with fences or replant them within their coffee plantations. Others establish small nurseries.

\section{Harvesting the scented green berries}

Men harvest the pepper berries from May to August - a task that is not without risks. The harvesters stand on scaffolds with beams and chords crossed between the large branches, and cut off the small fruiting branches. They moor themselves to avoid falling and use bows to collect fruit from the outlying limbs, harvesting up to $25 \mathrm{~kg}$ of berries a day. 
When the harvesters return home, the women and children pick the little green berries off the small branches. They spread the berries out over flat, cement surfaces or on bed rolls to dry in the sun. An important stage in the drying process involves making the berries 'sweat' - there needs to be just the right level of moisture content (or

Pepper berries are dried in the sun for up to five days. sudado) in the dried allspice. The first day in the sun ensures that the allspice acquires its characteristic scent and black colour, but it takes four to five days before the fruit is dried properly. Alternatively, the berries can be processed more rapidly in only nine hours, in an electric dryer. Grain sieves are then used to remove damaged fruit and sort the remaining berries by size.

\section{The allspice market}

At the beginning of the 1970s, itinerant traders would visit the region to buy allspice and then move on to hawk it in other towns and cities, like Cuetzalan or Veracruz. More recently, local farmers have organised themselves into associations of allspice producers, taking more responsibility for production as well as sales. With the support of the State, these small cooperatives have begun to export their produce via intermediaries.

The harvesting and processing of allspice represents an important economic activity for many families in the Sierra Norte de Puebla. In recent years this activity has come to the rescue of coffee growers, following the fall in international coffee prices. Indeed, allspice has become a more important source of income than coffee. For example, in Tuzamapan, in the Sierra Norte de Puebla, where about 56 per cent of the villagers are engaged in producing allspice, 17 per cent of their overall income is derived from allspice, with 11 per cent from coffee.

Although the prices of these international products are subject to instability and fluctuations, the two products continue to be important for the livelihoods of many rural households. The diversity of crops offers some protection against economic uncertainty or changes than can affect one particular crop, like coffee in this instance. Local people benefit greatly from the pepper trees, which provide a direct source of income, as well as seasoning for domestic use, medicinal leaves and shade for coffee plants. The plantations also provide valuable resources such as fruits, fuelwood, medicinal plants and herbs, highlighting the benefits of multi-use plantings.

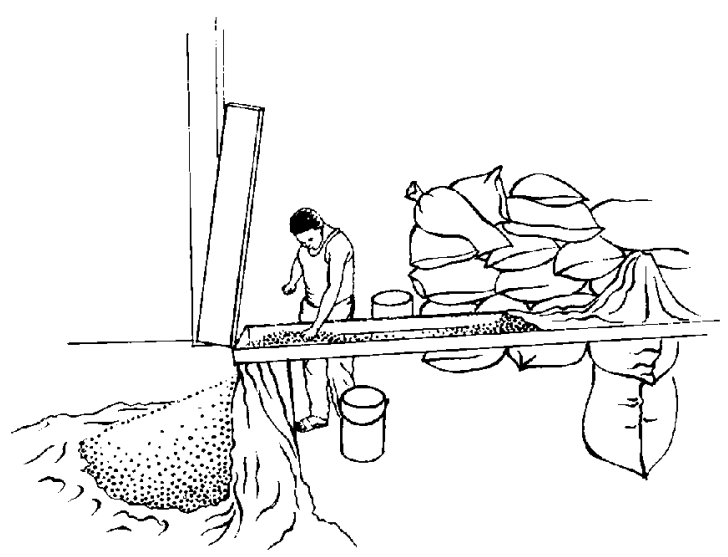

Grain sieves are used to assist the sorting process - helping to weed out damaged berries and separate the rest according to size.

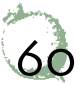




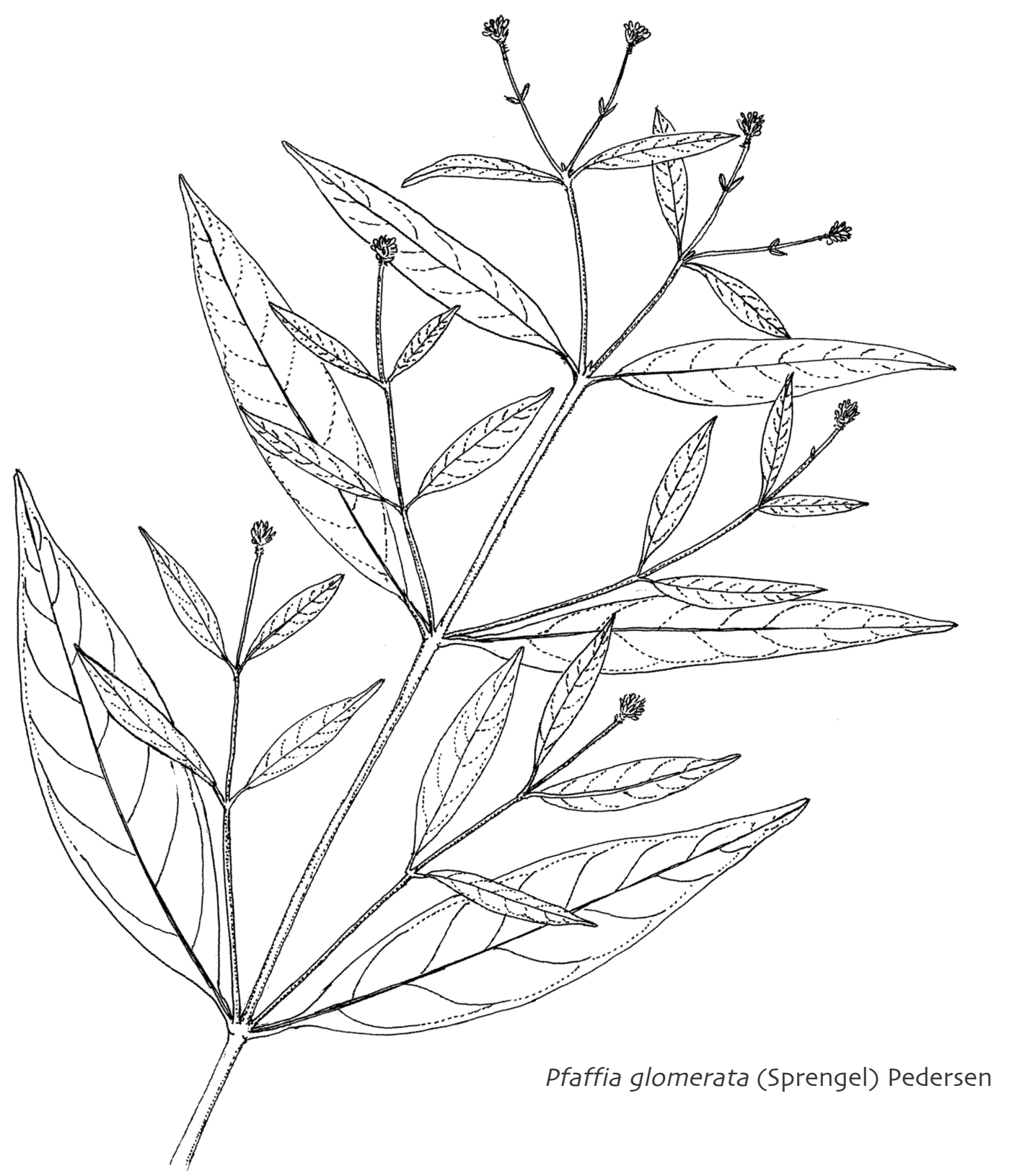

\section{Fáfia, Brazilian ginseng}

Brazilian case by Cirino Corrêa Júnior and Lin Chau Ming 


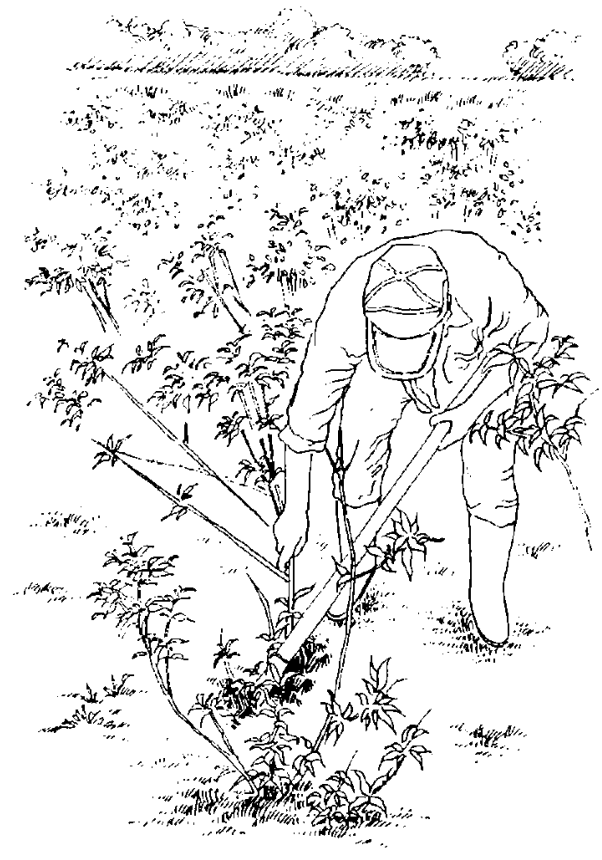

Harvesting fáfia is time consuming since the roots have to be pulled out manually.

\section{Fáfia extraction}

Fáfia has been widely used by local people but commercial harvesting intensified 12 years ago. The roots are pulled out manually with the aid of a spade or hoe, and in one day a collector may harvest up to $84 \mathrm{~kg}$ of fresh roots. The plants grow in "clusters", and the roots extracted from individual plants range in weight from about $250 \mathrm{gm}$ to $1.5 \mathrm{~kg}$. However, the harvesting season for fáfia is quite short, from May to July, when the land supporting these plants is not under flood. This timeframe coincides with the 'intercrop season', when farmers have the time and labour to devote to harvesting the roots.

Fáfia is somewhat difficult to find amidst the diverse wetland plant community. But it is one of the first species to resprout following burning, so farmers use fire as a means to locate it more easily. Fire is also used as a management tool to prevent areas becoming overgrown, and as a means to eliminate venomous animals. The use of fire is part of the traditional knowledge base of farmers in many regions of northern and southern Brazil. When uncontrolled however, fire can damage the environment and for this reason it is officially prohibited as a management tool in Brazil.

The preferred places for collecting fáfia include the islands of the Paraná River, as the roots are heavier and considered "better quality", largely due to the richer, wetter soils. The collectors carry the harvested roots home or transport them atop wagons, horses, bicycles or boats. In a little over a decade, fáfia has become a very important plant, not only for the Japanese, Europeans and Americans who consume it, but also for the rural families who collect it. Currently, three out of five people in rural families in the studied region are involved in the collection of fáfia roots.

\section{Processing and marketing}

The collectors sell the unprocessed roots to local buyers, receiving US\$ 0.10-0.13 per kilogramme, and an annual income of approximately US\$2,200 per household. The local buyers wash and chop up the roots, then mash them into a paste. Middlemen buy the resultant, sun-dried paste and mill it into a powder, before further drying and packaging it for export. Exporters pay around US\$ 15 per kilogramme, roughly 150 times the price of the fresh roots.

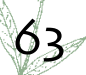




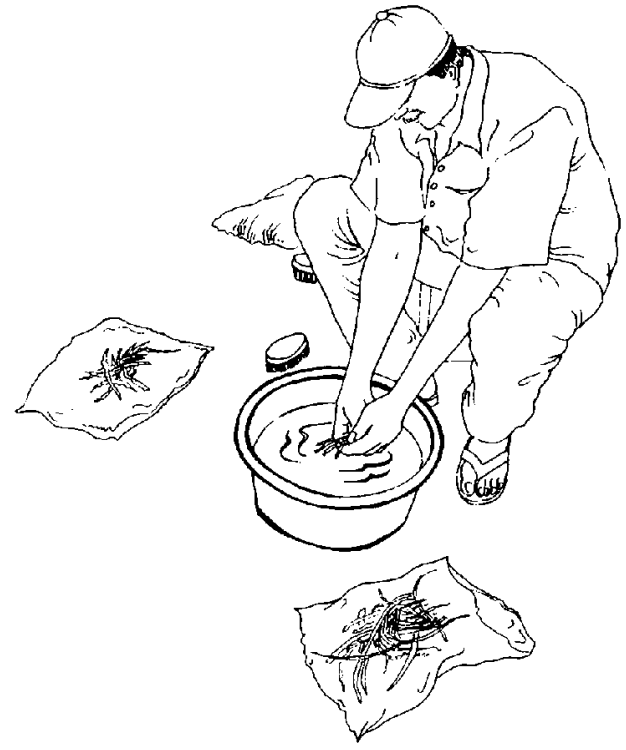

Local buyers wash the fáfia roots thoroughly before chopping them up and mashing them into a paste.

\section{Domestication: A win-win alternative?}

'Brazilian ginseng' represents a fascinating case of global substitution. In this instance, another plant's common name ('ginseng') has been used to promote the trade of fáfia, even though fáfia has no botanical link to its internationally recognised namesake. For centuries, from China to the Americas, the name 'ginseng' has been associated with a healthy, root-based tonic with potent restorative properties. The name game has worked. Over the last decade, the demand (which is mainly international) for fáfia roots has increased 10 per cent each year. As a consequence however, natural populations of fáfia have declined sharply.

If nothing is done, in spite of the efforts of environmental rangers to control illegal collection, the next few years are likely to see most of the wild fáfia disappear from protected areas and the Ilha Grande National Park. In an attempt to avoid the rangers, fáfia poachers concentrate on unpatrolled areas or harvest the roots under the cover of darkness. Their ability to evade control measures, and the lack of effective law enforcement, have led to degradation of the resource. In response to this over-exploitation, researchers and local farmers have joined forces to cultivate and domesticate* the species, making fáfia a potentially viable agricultural crop.

The domestication of fáfia allows farmers to grow the plant on their own land, rather than relying on wild harvesting. Farmers produce seedlings either by sowing seeds or planting stem or branch cuttings*, with the first option resulting in the hardiest seedlings. Farmers select the most vigorous plants to collect seeds or take cuttings from, an approach which helps to increase their crop yields. Field trials" have shown a productivity level of up to two tonnes of dried roots per hectare per year, based on 20,000 plants per hectare.

Prior to harvesting the roots, the farmers collect seeds or take cuttings for the next growing season. Producing their own seedlings in this way allows farmers to independently continue their cultivation of fáfia, ensuring that the economic benefits for local people from the collection and sale of fáfia are not lost as the wild supplies dwindle. The recent success in cultivating fáfia provides hope that more farmers may one day harvest roots in the light of day, without having to look over their shoulders for law enforcement officers.

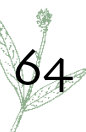



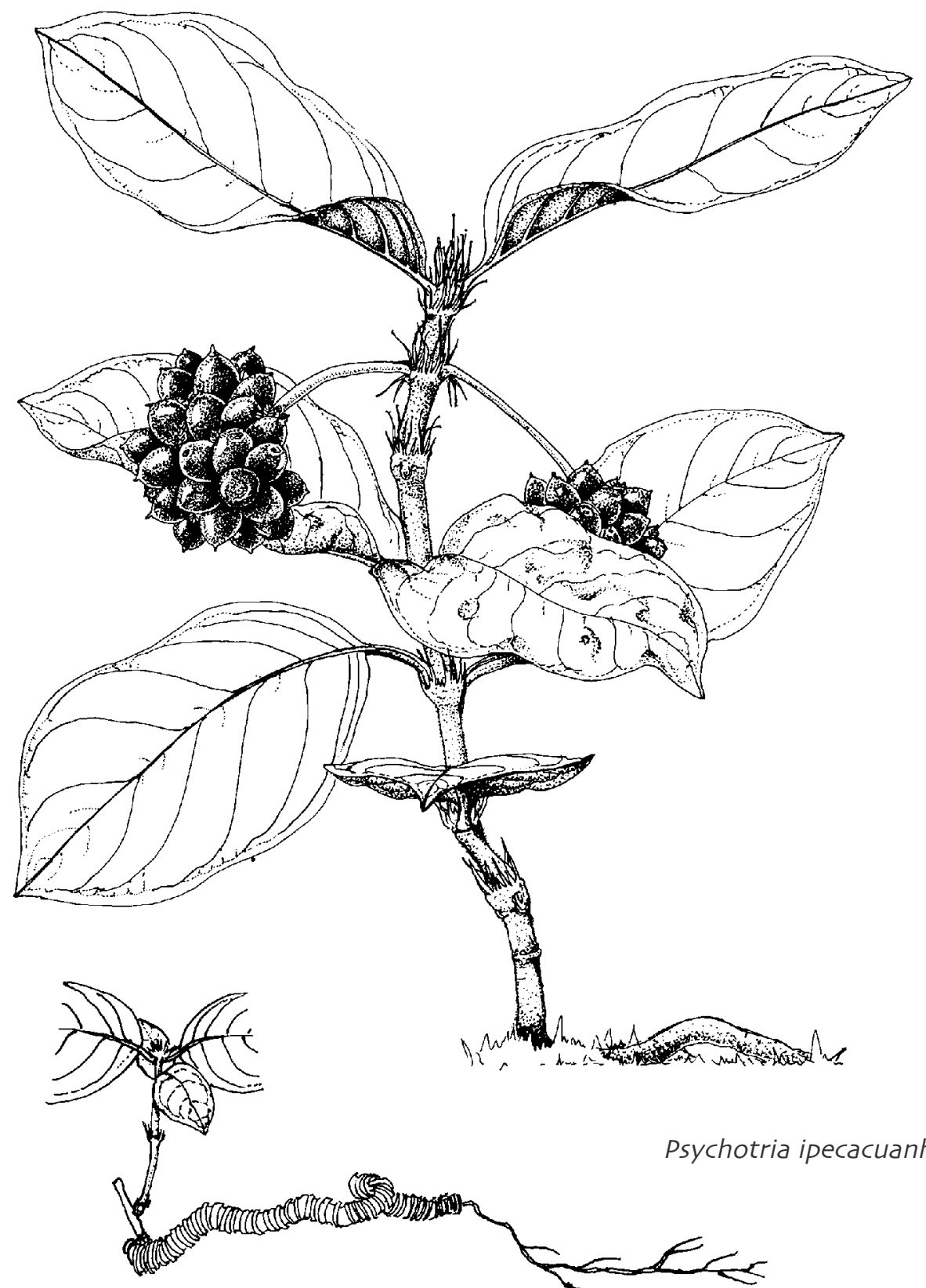

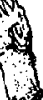

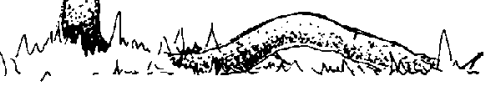

Psychotria ipecacuanha (Brot.) Stokes

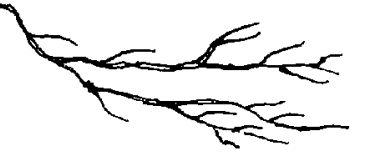

Ipecacuana, medicinal root

Costa Rican case by Rafael A. Ocampo Sánchez 


\section{Ipecac: A pharmaceutical from the forests of Costa Rica}

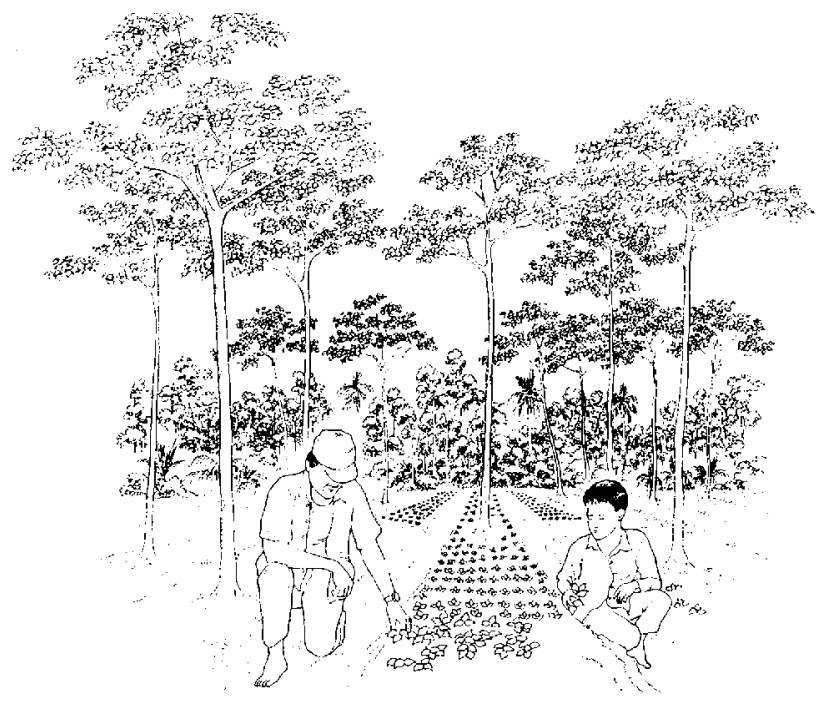

Ipecac seedlings are planted under the shade of forest trees.

The radiant rule of the fabled "Sun King" of France, Louis XIV, may well have faded early if not for a small plant growing in the forest shade half a world away. Ipecacuana (Psychotria ipecacuanha), which flourishes in the humid tropical forests of Central and South America, is rumoured to have cured Louis XIV of dysentery in the eighteenth century. Since the 1760 s the plant has been used in Europe as an amoebicide (to kill intestinal parasites), expectorant (to expel congestion from the respiratory tract) and powerful emetic (to induce vomiting). But the Guarani Indians of Central America were familiar with its healing powers long before this.

The international pharmaceutical industry began commercialising ipecacuana around the start of the twentieth century - recognising its value as a medicinal ingredient. The plant's modern name 'ipecac' is a derivative of the Indian term $i$ pe-kaa-guene, meaning "road-side, sick-making plant". But in Costa Rica, it is locally known as 'raicilla'. The active ingredients - the alkaloids* cephaline, emetine and psychotrine - are extracted from the root system. In the 1940s, especially during the Second World War, ipecac was one of the most widely used pharmaceutical plants in the United States of America and Europe. Today, it continues to be used to treat parasitic diseases, coughs and bronchitis. Many mothers around the world also stock a small vial of ipecac in their medicine chests as an emetic in case their children swallow something they shouldn't! In recent times, ipecac's potential role as a cancer treatment has also been under investigation.

\section{Low technology, high quality}

Ipecac is found in forests stretching from Nicaragua to Costa Rica and from Panama to Brazil. The plant grows $20-30 \mathrm{~cm}$ high, bearing small, white flowers and producing abundant seeds, which are dispersed by birds. This species grows best under the shade of trees, finding it difficult to tolerate direct sunlight. 
Ipecac was originally harvested from the wild in South and Central America, and this is still the case in Brazil. In Costa Rica and Nicaragua however, increasing demand has led to its cultivation within forests, with the canopy* protecting the plants from the direct sun. Across Costa Rica, about 35.5 hectares of forest land is used for cultivating ipecac, producing roots with good alkaloid content, particularly when the plants are in flower. Recognised for its medicinal qualities, ipecac has also been introduced into India, where it is grown in large monoculture* plantations. However, the quality of the alkaloid extracts is currently lower than in Costa Rica - although technological improvements aim to address this.

\section{Cultivation boosts supply}

The decline of wild stocks encouraged entrepreneurs and farmers to explore alternative ways to sustain supplies of this valuable medicinal species. The forest cultivation of ipecac began in Nicaragua, later extending to the neighbouring Huetar Norte region of Costa Rica in the 1850s. Local businessmen used the skills and knowledge of the indigenous* Malekus people, adapting cultivation practices to forest land.

In Huetar Norte, approximately 48 families now cultivate ipecac or raicilla as it is locally known. A steady stream of Nicaraguan immigrants entering the region have also become ipecac growers. Each hectare devoted to ipecac yields about 2.8 tonnes of dried root, worth around US\$ 17,000. But only 5 per cent of farmers are solely dedicated to growing this plant. Most grow a diverse range of native* cultivars* as well, including maize, beans, manioc" and tiquisque*.

Subtle ecological knowledge helps farmers determine which forest trees to cut and which to keep when undertaking clearing to plant raicilla seedlings. Raindrops falling from differently shaped and sized leaves have different effects: small-leaved trees are retained because they drip fine water droplets that will not damage the raicilla plants growing below. After planting, the forest patches are weeded every four to six months. The roots are collected after three to four years, with harvesting occurring mainly during the rainy season, as the moist soil makes root extraction easier. The harvested area is then left to rest for five to six years before being replanted. 
Women and children dry the harvested roots in the sun near their homes. The roots are then stored in sacks and are later transported to one of the two national exporting companies. There, they are broken into small pieces and wrapped for export. Further processing takes place abroad, in countries like the United States, Mexico, Germany, France, Thailand and Malaysia.

\section{A wild ride on the market}

Nicaragua, Brazil, Costa Rica and India are the main ipecac producing nations. Nicaragua supplies around 32 per cent of world demand, with Costa Rica supplying approximately 20 per cent. The Costa Rican Government encouraged farmers to establish ipecac plantations in the early 1980 s as part of a programme focusing on "non-traditional" cultivars. A co-operative was formed 10 years later to try to stabilise fluctuating prices and standardise sales through a single purchasing centre, but it collapsed after only a few years. Private enterprise contributed to the failure, abusing government subsidies by exaggerating the export figures.

Fluctuation of ipecacuana export prices

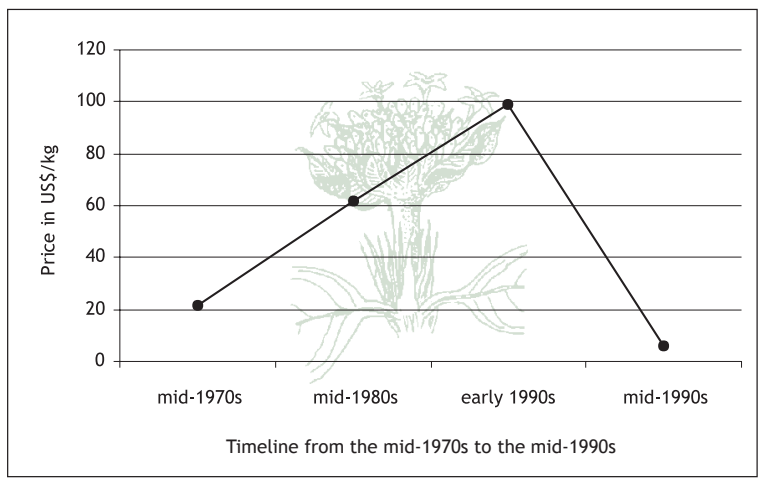

Price and trade fluctuations have been detrimental to ipecac production and the livelihoods of families associated with this activity. Excess production and international market stagnation have caused the drop in prices. Speculation and abuse of the national subsidy programme, as well as initially unrealistic expectations regarding high export revenues, have also contributed to the decline.

Ipecac production has fluctuated as wildly as global prices. Between 1961 and 1985, when production was stable, Costa Rica exported an average 20 tonnes per year. This volume peaked at more than 100 tonnes in 1989, before hovering around 65 tonnes until the mid-1990s. The export volume reached 100 tonnes a year again in 1996, but by 2000 , it had declined to less than 30 tonnes.

Producers are facing manifold problems: low prices, a stagnant market, a lack of government attention, competition from other nations like India, and synthetic substitutes. Another issue is deforestation. An increasing degree of land clearing for agriculture and cattle ranching means there are fewer and fewer fragmented primary forest" patches where the medicinal root can be cultivated. Farmers have responded by planting ipecac in secondary forest*, or under the shade of plantations like cacao. So far, they have managed to maintain a high alkaloid content in the roots, guaranteeing them the market edge with a high quality product. 


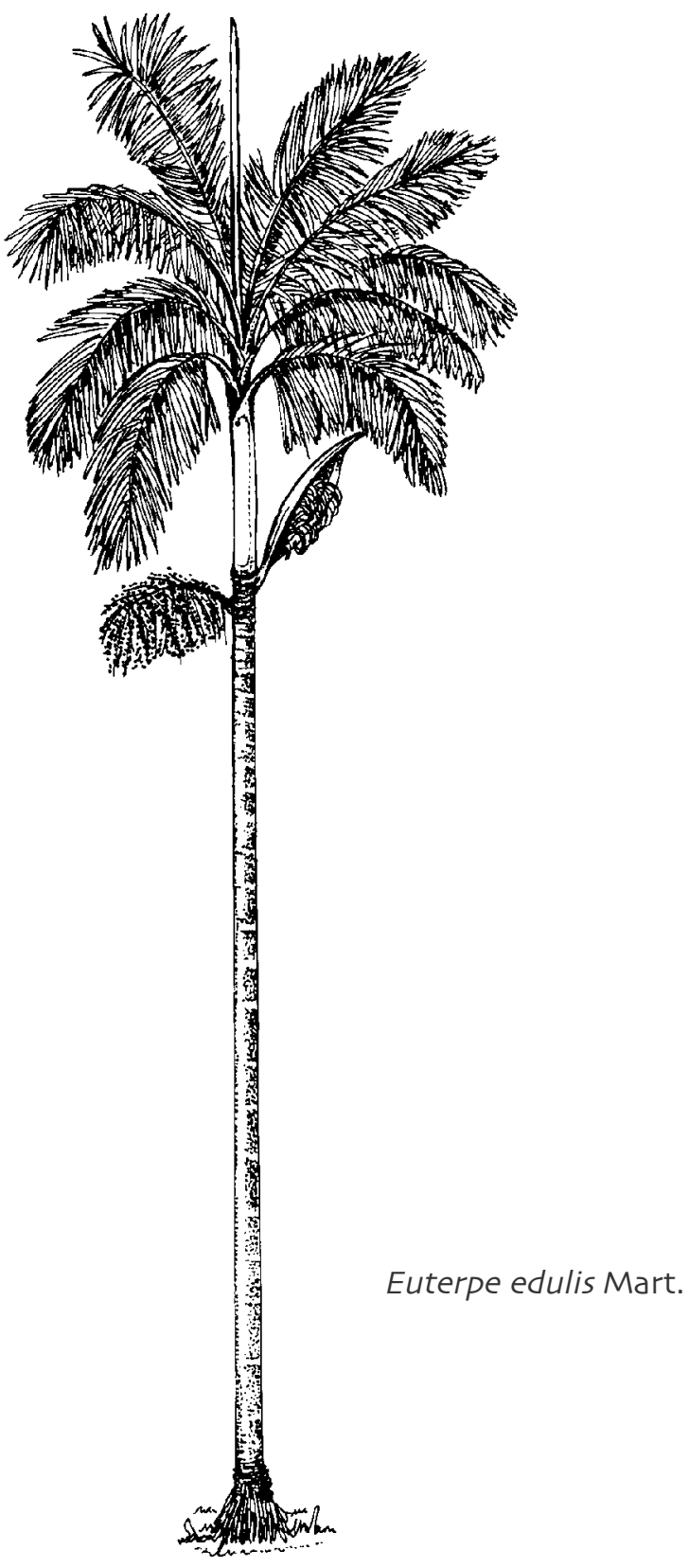

\section{Palmito, edible palm heart}

Brazilian case by Alfredo Celso Fantini 


\section{Palm heart: A delicacy from the forest}

'Palm heart' or palmito is a treat from the forest, appreciated by the native* Indian people well before the arrival of Europeans in America. It has since become one of the most popular forest products in Brazil. Consumed mainly in its preserved, slightly salty form, it makes an enjoyable side dish for any type of meal. Although some chefs from famous restaurants insist on covering palm heart with sophisticated seasonings, a true gourmet does not mask its natural flavour.

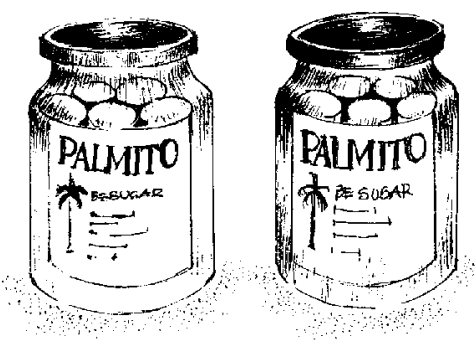

Palm heart is an enjoyable side dish to accompany any meal.
Until recently, in southern Brazil, the palm heart was an indispensable item served at important gatherings. Indeed, the abundance and diameter of the palm hearts offered to guests was a measure of the significance and success of an event. During festivities, the Euterpe edulis palm, known locally as palmiteiro, was used not only as a source of food but also as an elegant decoration - with whole leaves and stalks being used to adorn streets and houses. Although, this cultural tradition has been gradually disappearing. Traditionally, the trunks and leaves have been used as building materials. However, urbanisation of the Atlantic forest region has led to new construction materials entering the market and displacing palmiteiro.

\section{An abundant palm in pristine forests}

Fifty years ago, Euterpe edulis palms occurred naturally throughout the Brazilian Mata Atlântica, in a density of around 350 palms per hectare. However, deforestation in the region and over-exploitation has decimated the species. The sharp decline in the palm's natural populations has affected not only the region's plant ecology*, but also many animal species - including large birds, mammals and rodents - which have traditionally relied on the palm's abundant fruit production as a guaranteed food source during certain months of the year.

The 'palm head' is the green apical" part or tip of the palm trunk, formed by the sheaths* of the growing leaves. The innermost leaves, which are the youngest and most tender, represent what is known as the palm 'heart'. Harvesting generally takes place when the palm is 8 to 12 years old, and unfortunately the plant is killed in the process of extracting this delicacy. An adult Euterpe edulis palm may reach $15 \mathrm{~m}$ in height, but only a small part of it is utilised for food. An entire palm produces only one to two 300 gramme jars of palm heart. Virtually all of the palm heart produced in the Mata Atlântica region is extracted from forests and regrettably, the sustainable management* of the species is quite rare. 


\section{Legal and clandestine production}

Palm heart has contributed significantly to the incomes of many families living in the rural areas of Mata Atlântica. One of the advantages of harvesting is that the palm heart can be extracted at any time of the year, with the stock remaining in the forest being regarded as a form of "green savings". Until recently, farmers in need of some cash would cut out a bunch of palm hearts and sell them. That was when it was still common to find palm heart in natura (sold as palm heads) in farmers markets or roadside stalls.

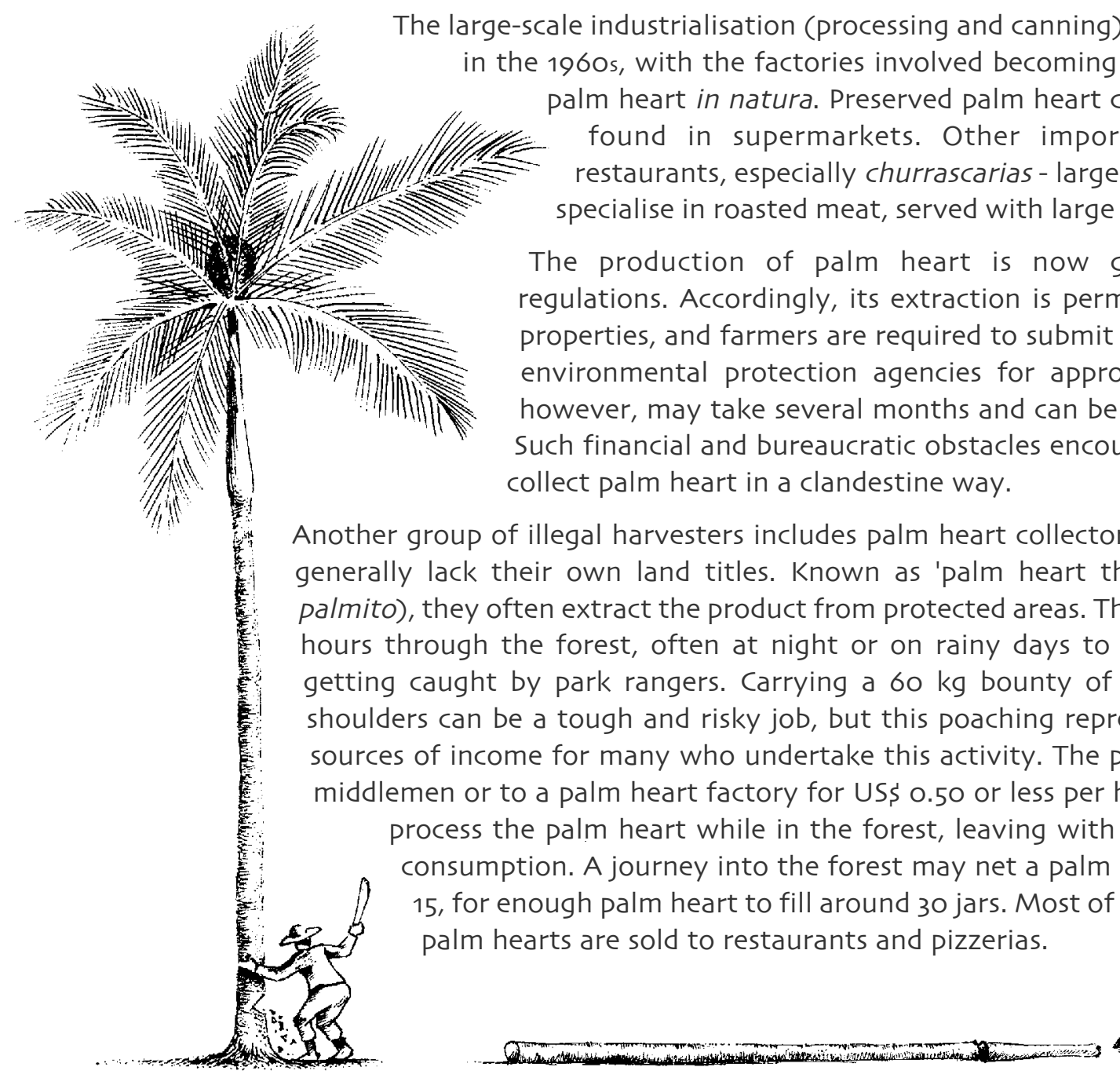

Extracting palmito requires whole palms to be cut down. The amount of palm heart

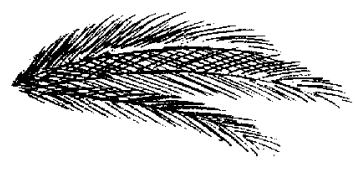
obtained from each adult palm fills just one to two 300 gramme jars. 


\section{Other species enter the scene}

Natural populations of Euterpe edulis, the original source of palm heart, have been in sharp decline for decades due to over-exploitation. Market share is now being captured by palm heart produced from related species such as Euterpe oleracea and E. precatoria, harvested from natural forests in the Amazon region. Recently, the peach palm (Bactris gasipaes) and the exotic royal palms (Archontophoenix cunninghamiana and $A$. alexandrae) have started to be cultivated in the south-east and south of Brazil, to provide an additional source of palm hearts. These species can be cultivated in open fields - an advantage over Euterpe edulis, which requires a shaded environment during the seedling stage. The direct sunlight also promotes faster growth of peach and royal palms compared to palmiteiro. But the high quality of palm heart from Euterpe edulis has motivated some farmers to start cultivating this species under the shade of tall crops like bananas. However, incentives from state agencies will be required if this practice is to become more widespread.

\section{From palm heart harvesters to pulp producers}

Another product obtained from certain palms is açai, a thick purple juice extracted from palm fruits. In the Amazon, where açai is very popular, the juice is extracted from Euterpe oleracea and E. precatoria. In the Mata Atlântica, aşai of the same quality can be produced from the fruits of Euterpe edulis - and although this practice is not currently common, demand for the product is growing fast. The collection of fruit to produce açai does not kill the palms - the biggest advantage of producing fruit pulp* instead of palm hearts. Each palm can then generate an annual income for farmers, as against a one-off payment for each palm's 'heart', plus new seed continues to be produced to enrich the forest with the growth of new palms.

As the road system in southern Brazil is much better than in the Amazon, local farmers are better able to become involved in the production and marketing of açaí. Rising demand and market opportunities for this product are stimulating many farmers in the Mata Atlântica region to keep their palms standing, bringing renewed hope for both the farmers and for the conservation of this species.
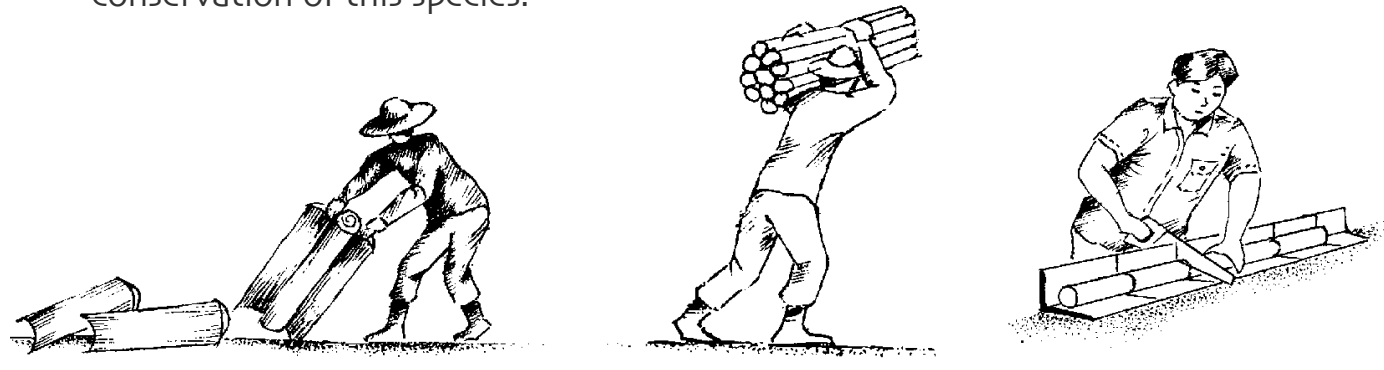

During industrial processing, the external sheaths are removed to access the palm heart, which is cut into small pieces and cooked within the jars.

The preparation of the 'palm head' for transportation consists of removing most of the external sheaths, leaving just a few to protect the soft palm 'heart'. 


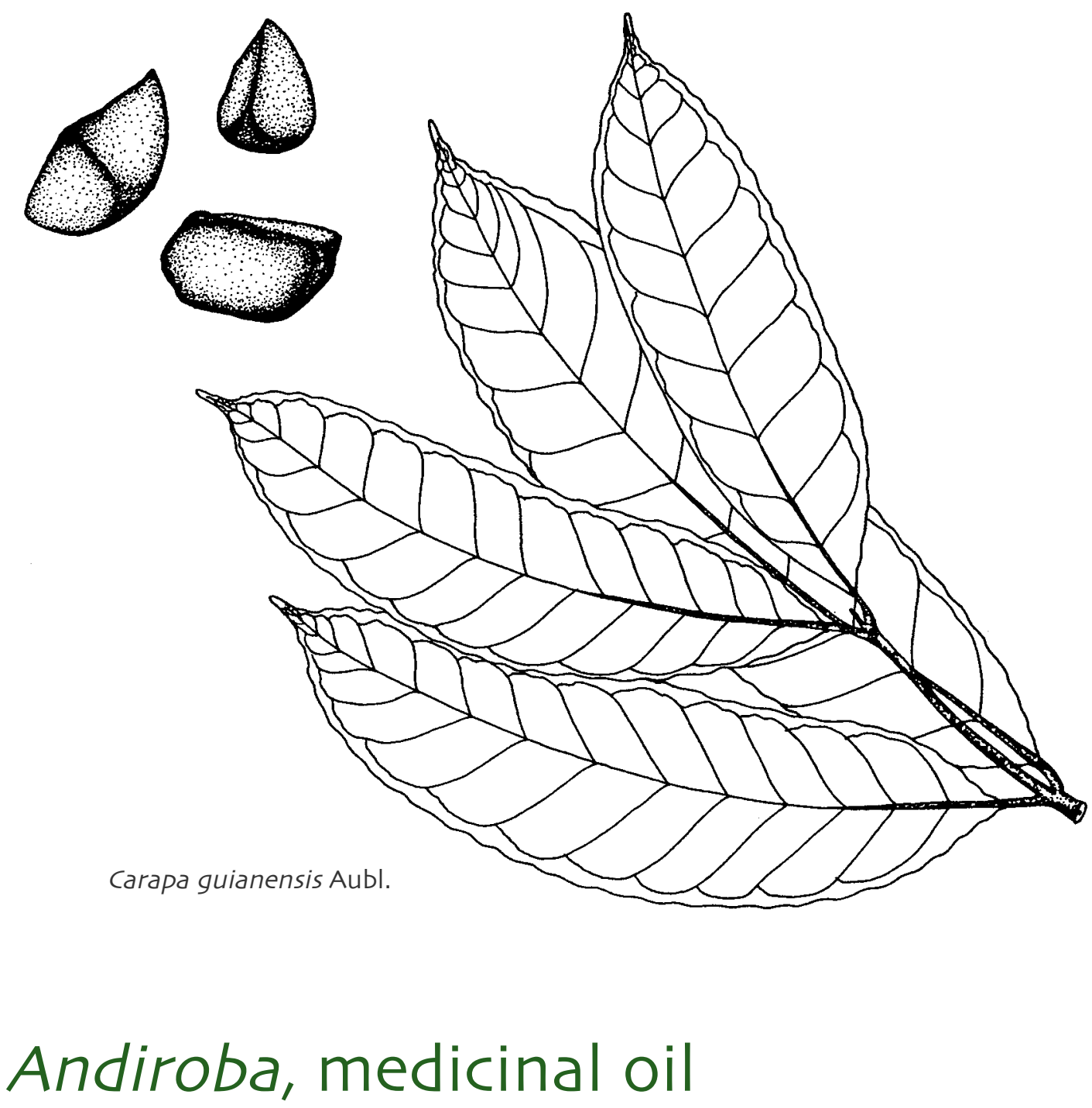

Brazilian case by Patricia Shanley 


\section{Andiroba: A healing salve to fend off bruises, bugs and dengue}

Are you watching your badly sprained ankle swell and turn purple? Nervously swatting the dengue-carrying, white striped mosquito to avoid disease? Taking your pup to the vet to cure his infected cut? Or, are you in need of fine looking, durable furniture? If any of these apply to you, you may want to track down the wood, bark or oil of a tree called andiroba (pronounced 'anjeeroba').

Dubbed 'crabwood' in Guyana and 'bastard mahogany' in Central America due to its lovely, red tinted, resistant wood, Carapa guianensis is a medium-sized tree with a buttressed base. Its straight trunk can reach $30 \mathrm{~m}$ and its thick bark flakes off in large pieces. The bark makes a bitter tea that is said by locals to be effective against worms and fever, and useful in the treatment of tumors. A powder made from the bark is also used for various skin problems. Apart from its bark and excellent quality wood,

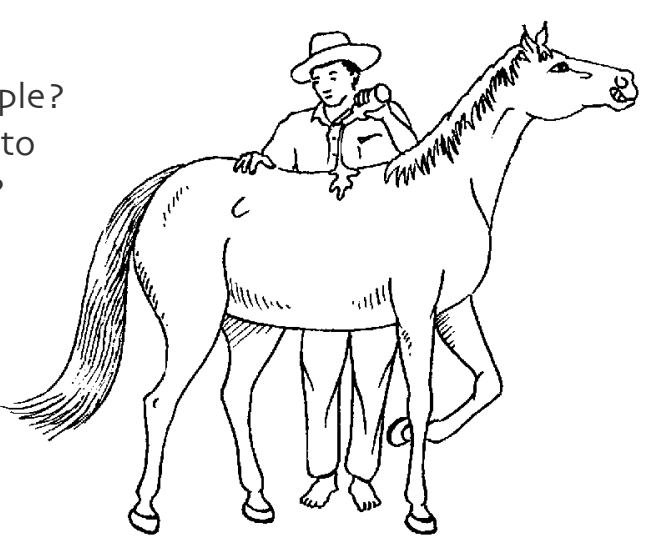

In addition to its human uses, domestic animals also benefit from andiroba oil as it helps to heal cuts, scratches and irritated skin. andiroba is most widely sought after for the sticky oil that can be obtained from its seeds. Used by everyone from farmers to city executives, andiroba oil is encountered more commonly than aspirin in the medicine chests of many Amazonian households.

\section{From birth to death: Baby ailments, insects and arthritis}

Used for centuries as an insect repellant, indigenous* groups in Brazil have traditionally painted their skin with a mixture of smelly andiroba oil and bright red pigment from the seeds of urucu (also known as annatto or Bixa orellana). This potion would keep pesky mosquitos at bay, while serving as a decorative cosmetic as well. Such resourceful practices are being rediscovered by international cosmetic companies which are now using urucu in the production of lipstick. Recently, industries in Brazil have also picked up on the discovery that using the seed hulls of andiroba in candles helps them to repel denguetransmitting mosquitos (Aedes aegyt).

Oil extracted from the andiroba seeds has traditionally been used in rural areas to make soap, a use that now extends to industries supplying a wide array of spin-off products (such as creams, shampoos and salves) to drug stores and supermarkets. The pure oil can also be purchased from these outlets. Andiroba oil is applied following the birth of a rural baby, to 
the umbilical cord after it is cut, and it is also an effective remedy against diseases such as arthritis. In downtown Belém in 1994, the combined sales of the two most popular Amazonian medicinal oils, andiroba and copaíba, reached 10,000 litres, tripling to 30,000 litres in 2002.

\section{Beachcombers harvest a forest remedy}

Andiroba occurs throughout Amazonia, Central America and Africa, preferring the margins of lakes and rivers but also growing upland in dry forest. The abundance of andiroba trees differs from region to region - densities may be as low as one tree per hectare or as high as eight. The production of seeds also varies enormously between different trees and years. As locals say, one tree may "rest" and produce nothing one year and the following year it may produce between 50 to $200 \mathrm{~kg}$ of seeds. Each seed is brown, a little larger than a golf ball, with smooth, triagonal sides.

Women, men and children collect andiroba seeds in forests and flood plains soon after they fall from the tree. On beaches along the estuary* where the Atlantic Ocean meets the Amazon River, collectors on foot, canoe, bicycle and buffalo-drawn cart scan the rivers, beaches and forests. Mindful of where rivers and tides deposit seeds, collectors adeptly pick andiroba out from amongst forest debris and shells. After collection, some harvesters sell the seeds directly to traders, who ship them for processing to the nearby Amazonian city of Belém or the far-away metropolis of São Paulo.

\section{Back woods processing: The key to andiroba's curative power?}

Traditional oil extraction is an involved, lengthy process, which varies between different places and people. The main steps involved include boiling the seeds and then letting them sit in a pile to ferment for about 25 days, before extracting the pulp from each seed. The pulp is then shaped into baseball sized balls, which are placed on a sloping surface in the sun (or shade) to allow the oil to drip out for a few weeks. Rural oil processors relate that $40 \mathrm{~kg}$ of

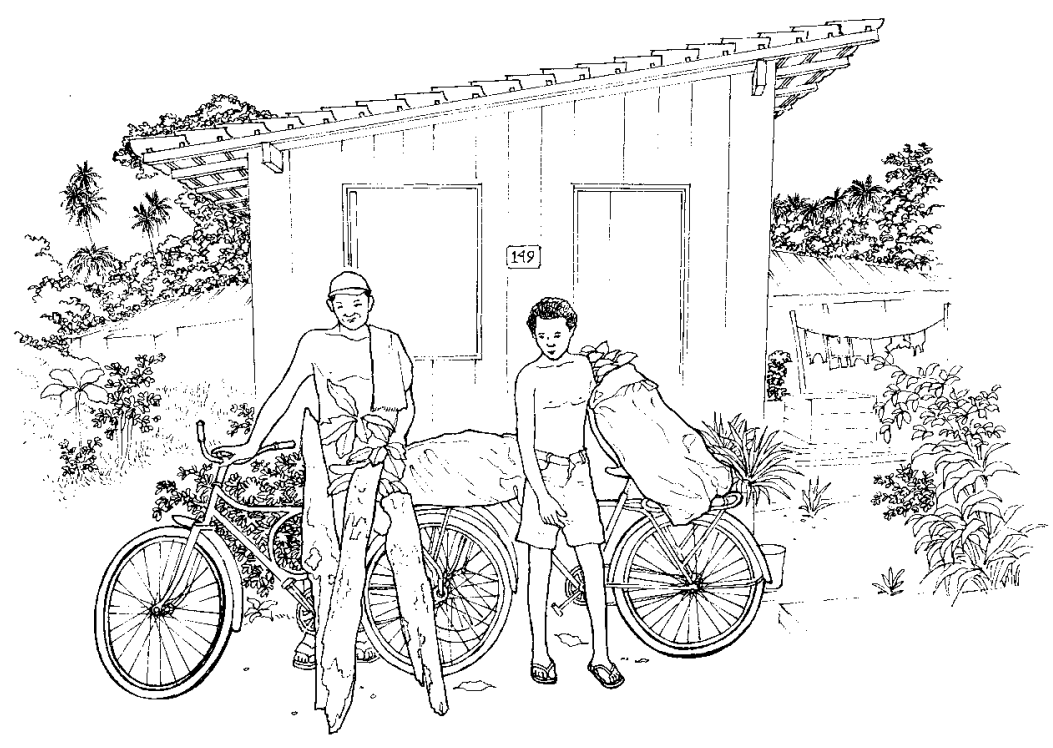

Collectors of medicinal bark and seeds arrive home after a long day's work. 


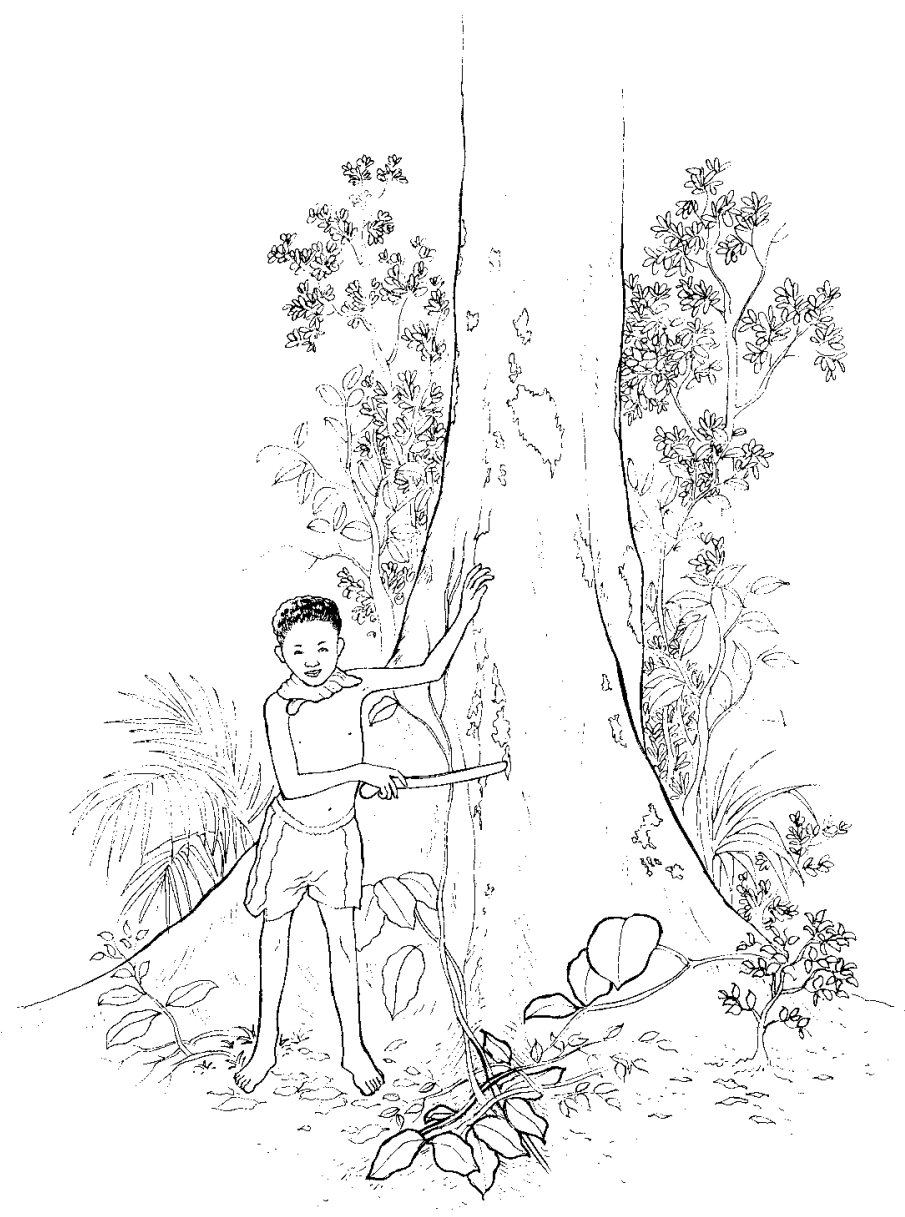

In logged regions, andiroba trees are in decline, limiting access to families who use the healing oil from these trees for basic health care. seeds may yield 1 to 4 litres of oil. By contrast, the industrial processing of $40 \mathrm{~kg}$ of seeds with chemicals and presses can yield 8 to 12 litres of oil. While traditional processing can take over 50 days, scientists at the Federal University of Pará state boast that, using solvents and presses, they can extract andiroba oil in one hour! Astute rural folk question whether such industrially processed oil can cure disease though - and scientists admit that some of the active substances obtained during the long, home-spun fermentation process do not appear in the rapidly produced oil.

\section{Conflicting use: Timber or oil?}

The attractive, reddish brown wood of andiroba is not attacked by ever-present termites, probably due to its bitter and oily nature. Because of the appearance, quality and durability of this wood, andiroba is valued for cabinet and furniture-making, and is one of the first species to be logged in frontier regions. In the decade between 1987 and 1997, the timber from approximately 30,000 andiroba trees was exported from Belém. However, export consumption accounts for only a small fraction of what is actually logged - domestic consumption accounts for about 86 per cent of the sawn logs produced in Brazil.

Field research suggests that after ten years of growth, andiroba offers seeds for oil production and after 18 to 25 years, it can be harvested for its highly valued wood. Growing interest in both the production of wood and the sticky, healing oil is fueling community interest in management. Demonstrating foresight and courage, women in Cameta, Gurupa, Porto de Moz and the Tapajos National Forest, are organising to protect andiroba trees from logging to ensure that there will be sufficient seeds to make the healing oil for their families. 


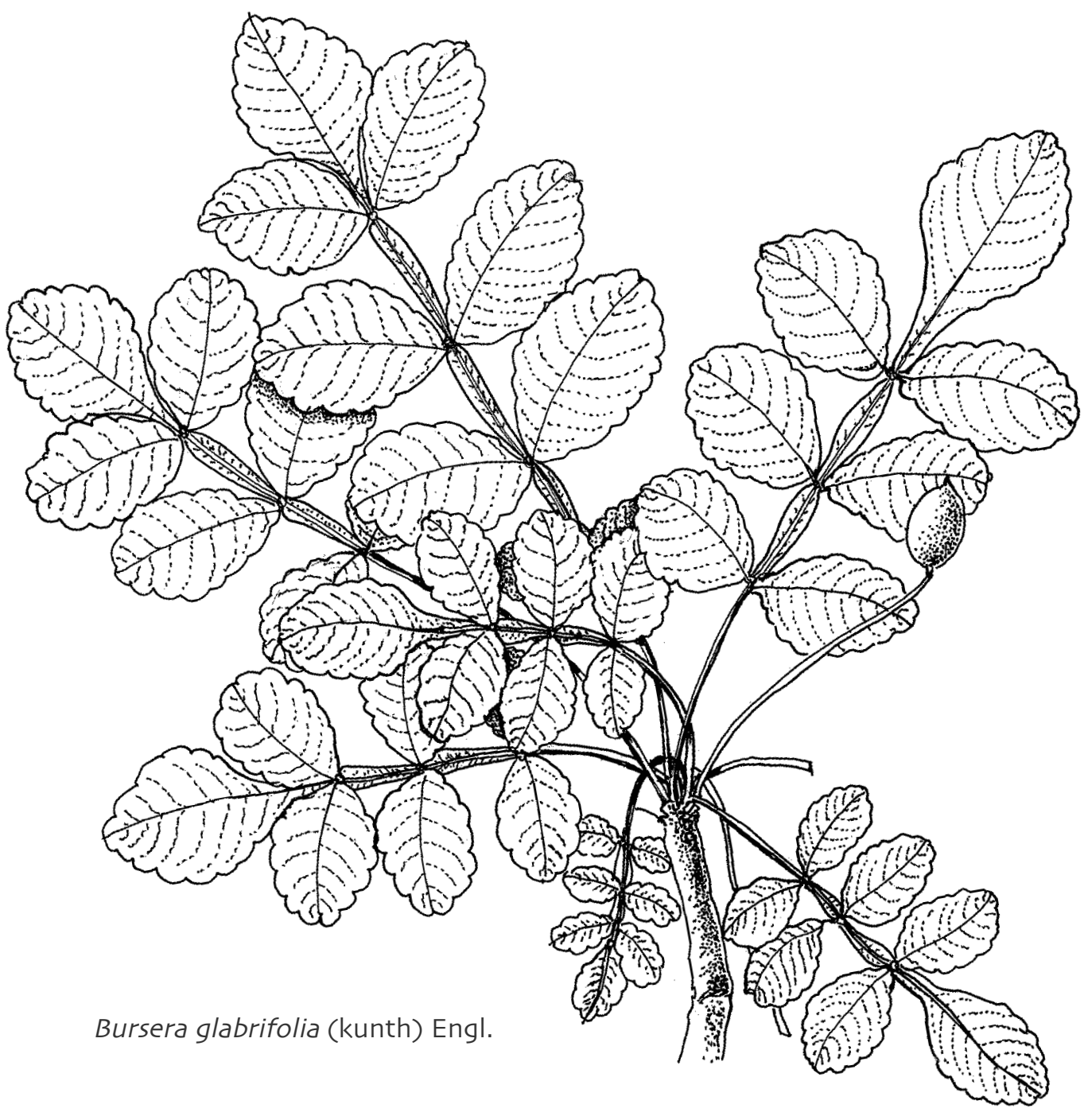

\section{Alebrijes, wood carvings}

Mexican case by Silvia E. Purata, Berry J. Brosi and Michael Chibnik 


\section{Alebrijes: Mexico's flight of fancy carved in copal wood}

The Mexican state of Oaxaca is well known for its rich culture and artistic traditions. In the Valles (entrales region, where the city of Oaxaca (echoing the state's name) is located, a new form of handicraft arose a little more than 20 years ago. Colourful wooden figures known as alebrijes are carved in the form of fantastic animals, mythical figures like mermaids and dragons, and human-animal hybrids. The informal tradition of wood carving stretches back many generations, but these newer figures are novel creations that lack the longstanding cultural significance associated with the more traditional carvings. Over a short period of time however, they have become one of the best-selling Mexican crafts in the United States of America.

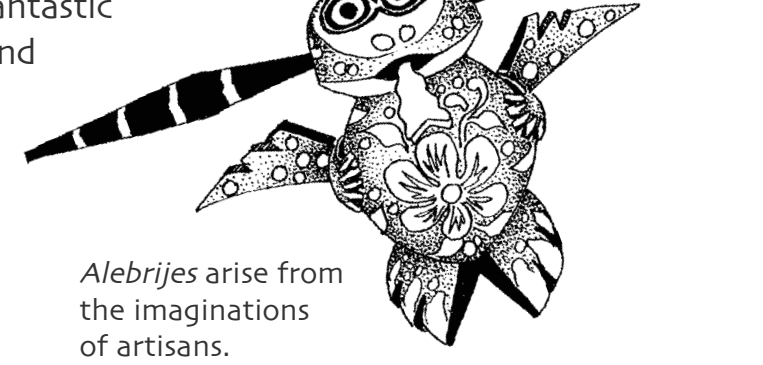

The artisan Manuel Jimenez, from the village of San Antonio Arrazola, is credited with creating the successful alebrijes style. His designs provided inspiration for others in nearby villages. The carvings are now being produced in family workshops and are sold directly to customers in the artisan villages, markets and craft stores of Oaxaca and other Mexican cities. They can also be found in craft stores in the United States and Canada, and in European countries like France and Spain.

Trade in woodcarvings has dramatically boosted the incomes of many families in the Valles centrales region. These families have built new houses and have bought cars, refrigerators and televisions with their earnings. Many of them are now able to send their children to secondary school as well. However, the increasing demand for wood has led to more and more trees being cut down within an ever-expanding area around Valles Centrales - where the principal artisan villages are located.

\section{The timber of artistic expression}

The wood used to carve alebrijes comes from various species but mainly Bursera glabrifolia and Bursera submoniliformis. Both belong to the genus* Bursera, within the frankincense and myrrh Family (Burseraceae). Locally known as copal or copalillo, Bursera trees can be found in the dry tropical forests of Oaxaca and neighbouring states. All of the wood used for carving 
continues to be extracted from the wild. Harvesting is generally quite simple because the trees are relatively small and the wood is soft. Trees are felled using an axe or chainsaw, and branches are cut with machetes.

When copal trees disappeared from Arrazola and San Martín Tilcajete (the two main carving villages) due to over-harvesting, artisans went to neighbouring villages to buy wood - until local authorities developed regulations to address the issue of over-exploitation. The people who sell copal wood to artisans are known as copaleros and come from outside the artisan communities. As the wood supply became increasingly scarce locally, or as regulations were introduced, the copaleros extended their harvesting range to increasingly distant areas - leading to significant price rises for artisans (and a corresponding fall in their profits). The commercialisation of wood without a government-approved management plan is illegal under Mexican forestry law. So harvesting and selling is often conducted in a clandestine way, with the majority of wood carriers using quiet back roads, generally at night or very early in the morning.

\section{Transforming branches into fantastic figures}

The creation of carvings involves several steps. When the wood is sufficiently dry, artisans select branches that roughly match the shape of the figures they have in mind. Suitably sized pieces are cut off and the bark is stripped away. Carvers first whittle the pieces of wood down into general shapes using a machete. They rely on different tools to finish off their creations: some use mostly gouges; others use chisels; still others work only with machetes and knives.

In some villages in Oaxaca, artisan families attract tourists with imaginative signs outside their houses advertising their handicrafts.

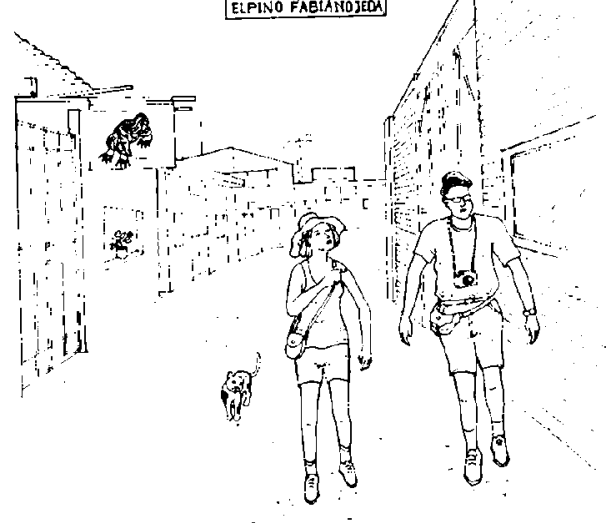

The artisans learn their basic skills from other carvers, but their personal choice of tools is largely the result of individual experimentation.

Many of the carvings have attachments such as ears, wings and tails, made from separate pieces of wood. These are either joined to the figure with nails or glue, or are fitted into specially made slots. The slots allow tourists to easily disassemble and transport the items, particularly complex figures with many parts.

When the demand for alebrijes increased in the 1980s, male carvers asked their wives and children to help with the sanding and painting. Carving quickly became a family activity, undertaken in simple workshops. Once the figures have been carved they are dried in the sun to reduce their moisture content. Sometimes they are briefly soaked in gasoline first to guard against wood-boring insects. When dry, the carvings are sanded to make them smooth before being painted. 
Most figures are painted in two stages. A solid base coat is quickly applied - occasionally with a sponge rather than a brush. The carvings are then painstakingly decorated with dots, wavy lines, geometrical figures and other designs, using differently sized brushes. Applying the base coat is an easy task, which is sometimes given to children or others learning to paint. Decorating is much more difficult and is left to the skilled artisans. Until around 1985, most painters used aniline, a powder mixed with water. While some carvers continue to use this product, most have switched to the glossier and thicker acrylic (vinyl) house paints.

\section{Trends}

As part of an effort to improve the management of Bursera species in Oaxaca, researchers have worked with the wood harvesting and artisan communities, documenting the principal routes of commercialisation and studying the demand to estimate how much wood is being extracted. The research into sustainable management*, in the Oaxacan community of San Juan Bautista Jayacatlán, has involved extensive inventory work and growth studies (investigating the rate of increase in tree diameters), which allows the researchers to calculate yields.

Working with this community, a tailored management plan was developed to promote the sustainable harvesting* of Bursera. This was the first community-based management programme that researchers have ever developed for a tropical dry forest in Mexico. It illustrates how scientific research can respond to local needs, with benefits for local actors and the environment. Fortunately, the species is not too slow growing and is relatively abundant in the natural forests of Jayacatlán. With sustainable harvesting, natural regeneration will be sufficient to meet demand without the need for cultivation.

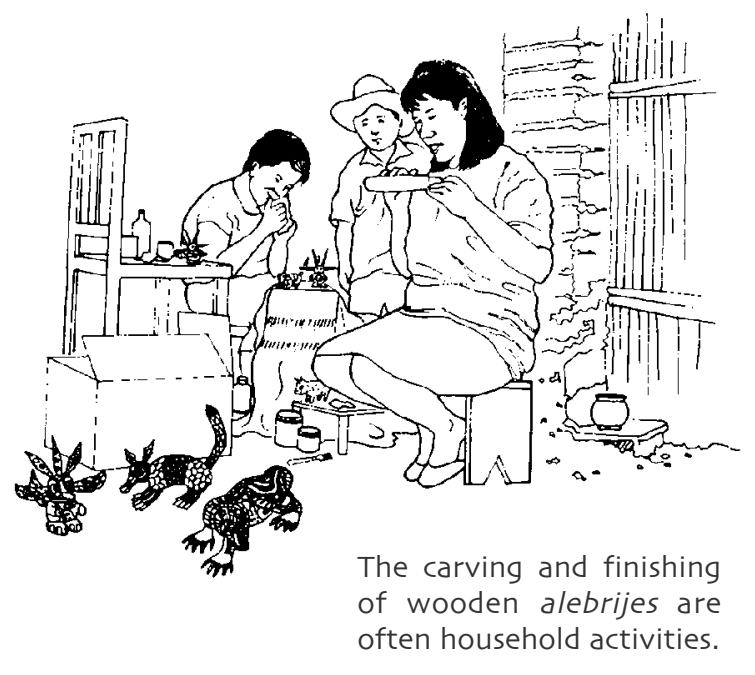

The management plan is now in its first stages of implementation. The researchers hope to use Jayacatlán as a model for other wood-producing villages, since the wood being harvested in Jayacatlán is not sufficient to provide wood to all carving villages. With examples of villages engaging in sustainable production, tourists to Mexico will continue to enjoy the likes of colourful monsters, monkeys and mice as they stroll through marketplaces and plazas. The hope is that such management initiatives will allow carvers to continue to derive benefits and pleasure from their craft, and that the Bursera species will continue to grow within local forests. 


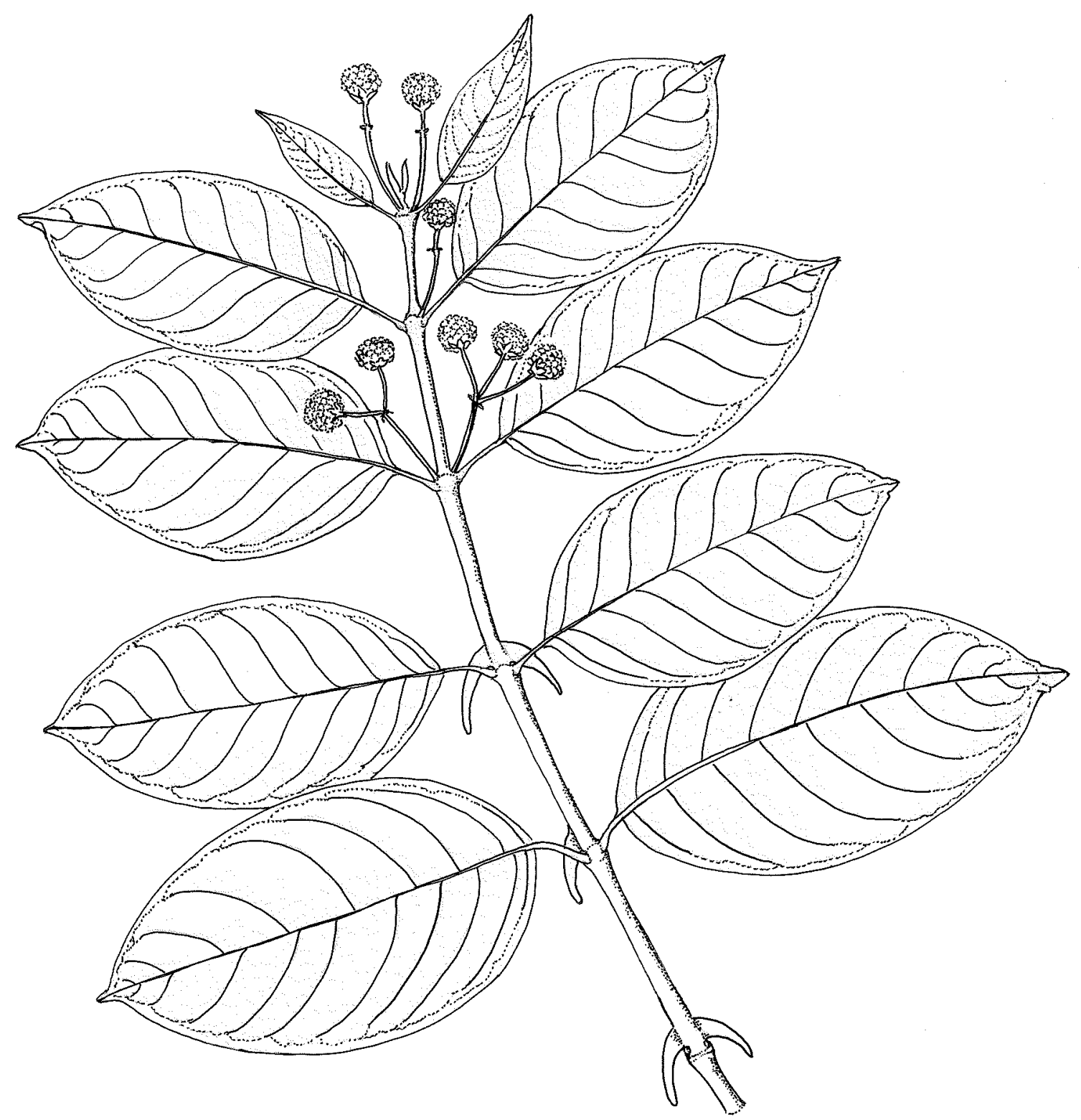

Uncaria tomentosa (Willd. ex Roem. \& Schult.) DC.

\section{Cat's claw, medicinal vine}

\section{Peruvian case by Wil de Jong and Walter Nalvarte}




\section{Cat's claw: An immune-boosting Amazonian vine}

For centuries, the indigenous* Cashibo, Conibo Shipibo and Asháninka people of Peru have used bark from a vine called 'cat's claw' to make a medicinal remedy and beverage. Traditionally, cat's claw is prepared as a decoction* by boiling the inner layer of bark from the stems or roots. The resulting drink is either consumed for its health giving properties, or is steeped into an alcoholic beverage using locally produced sugarcane rum. The bark decoctions are considered to have an anti-inflammatory* effect and to act as a stimulant for the body's immune system. In rural communities in or near the tropical rainforests of Central and South America where this plant grows, medicinal plant experts even contend that cat's claw can heal tumors.

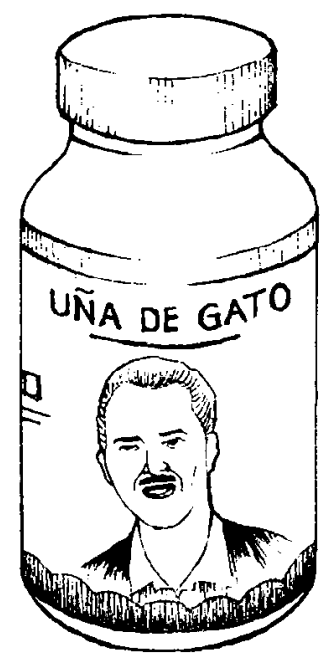

Today, cat's claw is sold in many different forms within Peru, and it is exported to around 30 other countries.

\section{Research and publicity}

The indigenous use of cat's claw attracted the attention of Western researchers and scientists, who began investigating its medicinal properties in the early 1970s. Studies conducted over the last 30 years have identified 60 active compounds, and have confirmed cat's claw's anti-inflammatory and immunestimulating properties. Other medicinal properties are yet to be fully investigated. However, well publicised personal accounts about the success of this plant remedy have led to its increased use in both Europe and Latin America, and even among some indigenous groups in Peru, who were previously unaware of its medicinal properties.

The export of cat's claw from Peru began in the 1970s and rose dramatically in the 1990s, following the publication of research results and personal accounts documenting the plant's medicinal uses. For example, in 1991, after a well-known Mexican actor claimed to have been cured of prostate cancer, the plant's popularity increased. Since the early 1990s, cat's claw has been used both in Peru and in European countries as a supplementary treatment for cancer and AIDS, and for other diseases that target the immune system. By the mid-1990s, the bark was being sold in Peru's major cities, and exported to 30 other countries, including Austria, Bolivia, Ecuador, Hong Kong, Italy and the United States of America. In 1995, its export value reached US\$ 3.3 million. 


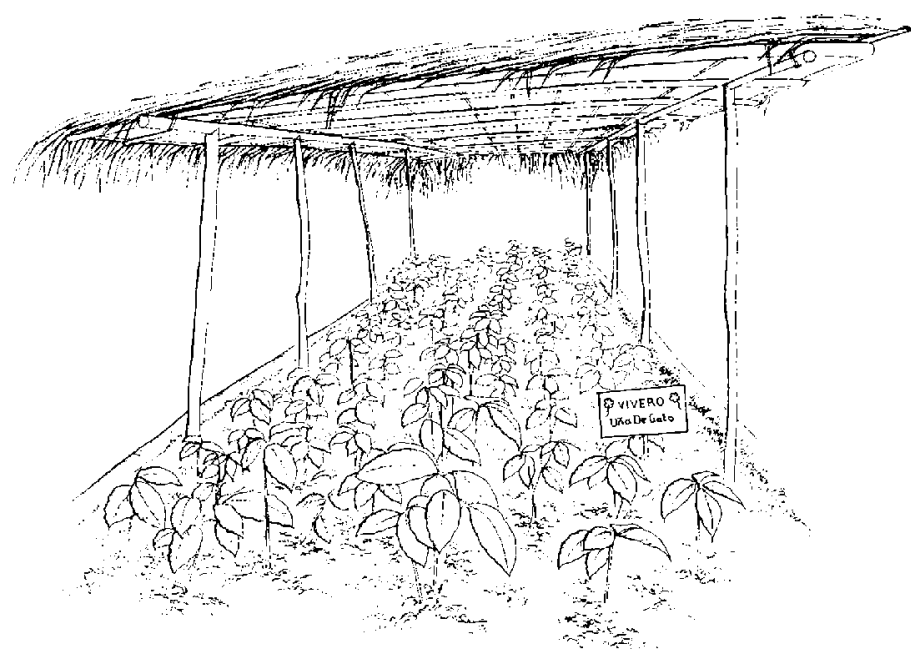

Cat's claw is sometimes cultivated to help meet the demand for this medicinal bark.

\section{Wild or planted?}

Cat's claw (Uncaria tomentosa) grows naturally in mature rainforests, from Paraguay to Belize, and is most commonly found at high altitudes (400-800 $\mathrm{m}$ above sea level). The name 'cat's claw' is derived from the vine's claw-shaped thorns, which it uses to climb up to $30 \mathrm{~m}$ into the forest canopy*. Another related species, Uncaria guianensis has more tightly curved thorns, which cannot latch onto branches as effectively. This species grows readily in disturbed areas and along rivers and roads. Both species are used and traded, and are frequently confused botanically.

Several government institutions in Peru, as well as private sector industries, have spent time investigating the reproduction of cat's claw. Their findings have shown that Uncaria tomentosa needs to be grown in association with trees to facilitate its vertical growth. However, young seedlings do not grow well if there is too much shade, preferring openings in the forest where there is sunlight. This is one of the reasons the vine reproduces quite vigorously following disturbance of its forest home, when clearings are created. Experiments suggest that cat's claw takes approximately 10 years to reach full maturity, with stem diameters of around $10 \mathrm{~cm}$. When it grows naturally in the forests, U. tomentosa may occur at densities of two to eight plants over a one-hectare area.

Cat's claw is harvested from both primary* and secondary forests". Following the boom in sales of this medicinal plant in the 1990s, some farmers in the Peruvian Amazon began planting cat's claw in secondary forests and in their home gardens, as an additional source of supply and income. However, the majority of the production comes from natural forest growth.

\section{The trade chain}

Cat's claw collectors cut the mature vines, stripping the bark and carrying it back to their homes. There, it is dried, cleaned and cut into small pieces suitable for sale. The bark is then sold in medicinal plant sections of markets, in cities such as Iquitos, Pucallpa and Lima, the capital of Peru. More advanced processing takes place in Lima where, in addition to selling the bark, traders also grind it into finer pieces or a powdery form, for use in teabags or within capsules. These products are later sold in pharmacies and supermarkets throughout 


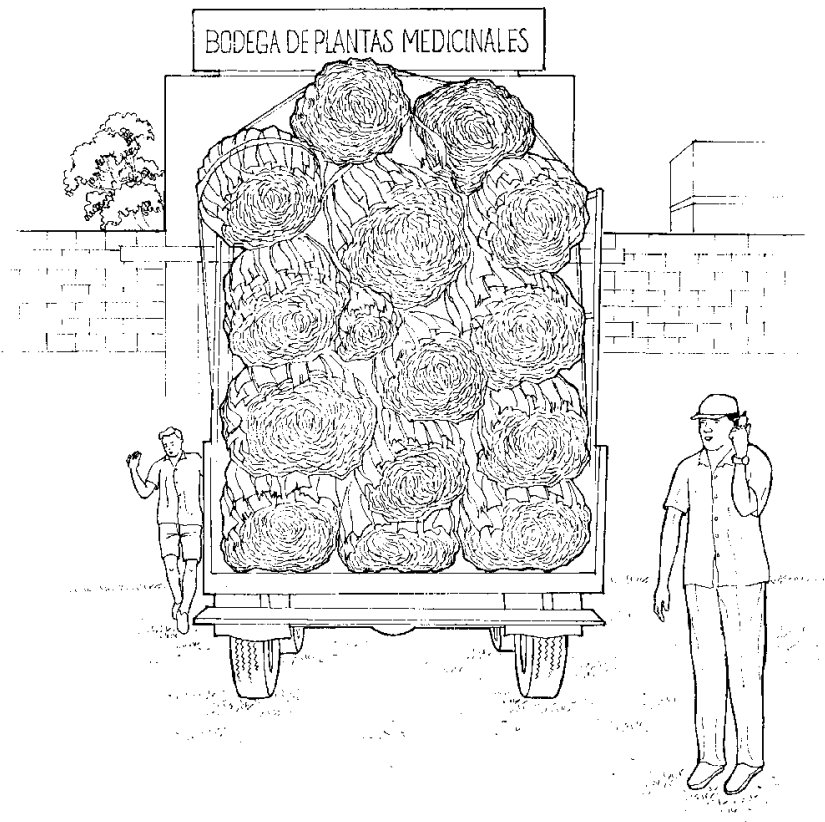

After the bark is collected it is transported to the centros de acopio or collection centres. the country. Internationally, cat's claw bark is traded in a semi-processed form. Typically, a local trader buys the bark from various collectors and then sells it to a Lima-based company, which in turn, ships the bark to businesses overseas.

Botanical medicine companies in Lima have developed a series of products based on cat's claw. Besides grinding the dried bark, they also freeze-dry the extracts, facilitating export and guaranteeing the consistency of the active components.

Most of the bark harvesters work as hired labour. They generally come from indigenous or migrant families living in the interior of the Peruvian forests, close to rivers, their main transport routes. These families practice agriculture, fishing, hunting and the harvesting of forest resources like cat's claw, for both household consumption and for trading in local markets.

\section{Trends}

Between 1995 and 1997, sales of cat's claw bark sky rocketed, but in recent years the sales have declined. This downward turn may be due to market saturation. However, some people believe that the entry of poor quality products during the boom could have resulted in a loss of consumer confidence. For example, in addition to Uncaria tomentosa, the related species $U$. guianensis, which can be found more easily, was also collected and the two species were sometimes sold in combination as 'cat's claw'.

Although overall sales have recently decreased, cat's claw remains important both medicinally and economically. Chemical analysis has verified the existence of active compounds, and enthusiasts maintain that the species has potential in the development of modern medicines. Because cat's claw regenerates well in secondary forests and disturbed areas, production could meet rising demand - if the public decides that it works. 


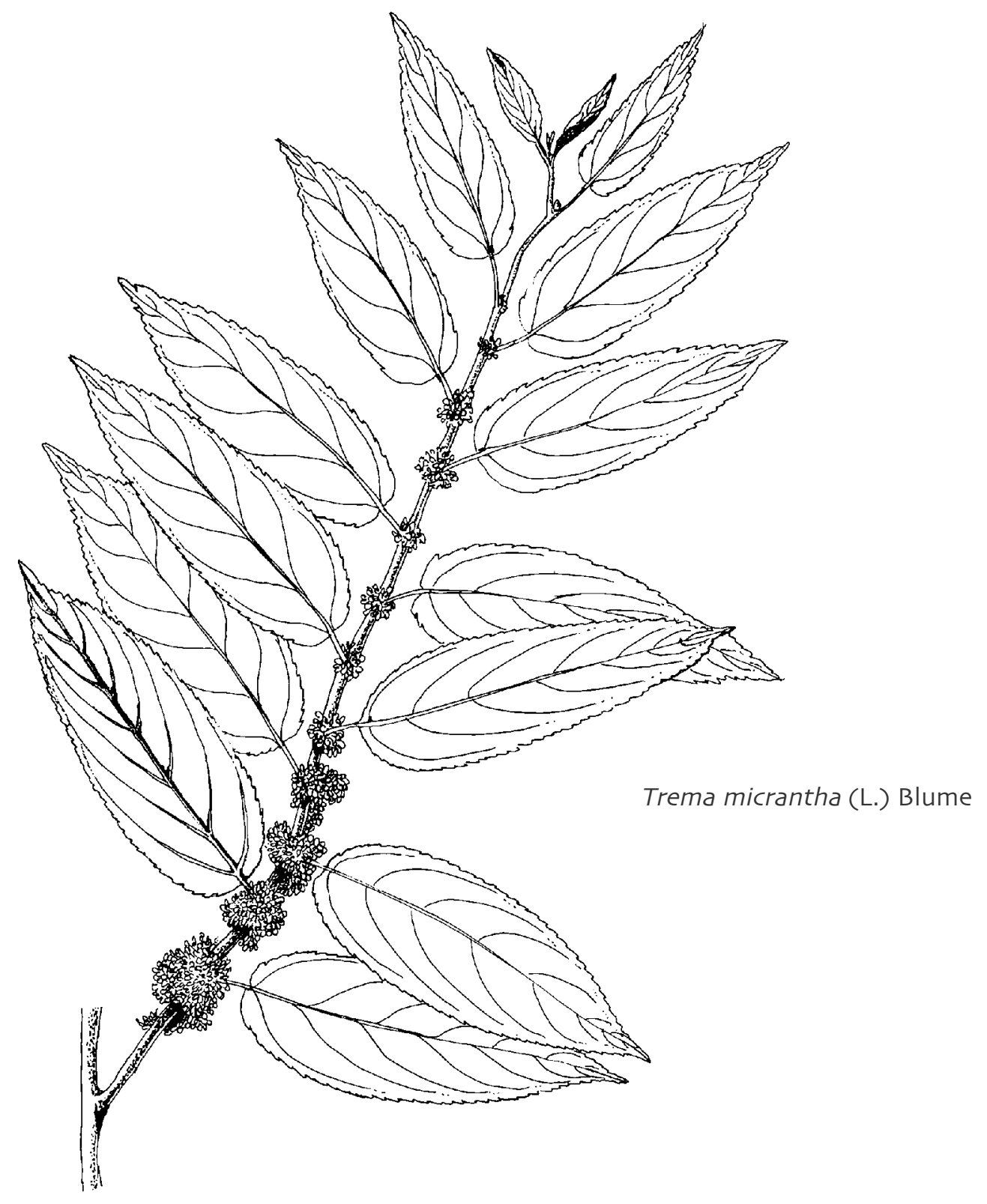

\section{Amate, bark paper}

Mexican case by Citlalli López 


\section{Amate: A modern market for traditional bark paper}

Tourists in La Ciudadela, Mexico City's largest handicraft market, wander along alleyways lined with beautiful textiles, ceramics, wooden masks and piles of distinctive, creamy brown paper bearing colourful paintings of flowers, birds and rural life. Called 'amate', this traditional paper is now made mainly from the bark of the Trema micrantha tree, using techniques that date back to preHispanic times. Tempted to buy some? For many tourists this is a perfect souvenir - light, easy to transport, and cheaper than other handicrafts.

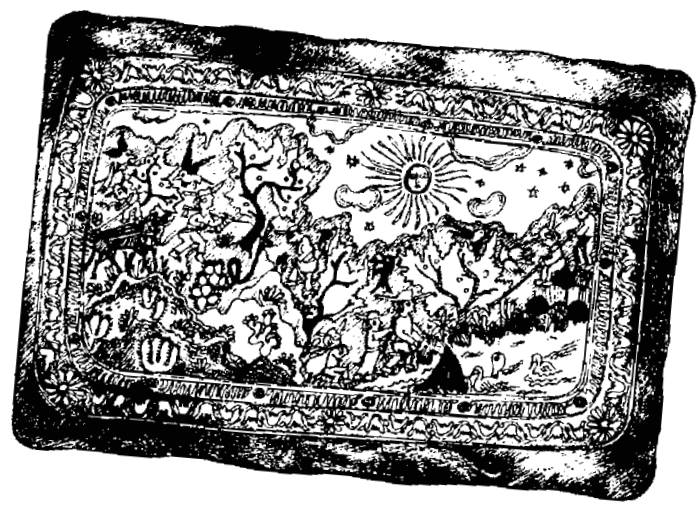

Today's bark paper handicrafts are the result of the combined creativity of the Otomi and Nahua people.

\section{A long history}

Evidence of bark paper manufacturing in Mexico dates back to 300 A.D. In the fifteenth century, before the Spaniards arrived, priests used amate paper for ceremonial dresses and offerings to the Gods. Amate books recorded history and mythical stories, and calendars guided agricultural activities and rituals. The bark paper was also used to pay 'tributes', a kind of tax. So much bark paper was needed that the inhabitants of about 40 villages were fully dedicated to manufacturing it.

Like many aspects of indigenous* culture, the production of bark paper was forbidden by the Spanish colonists. Wanting to impose their Christian religion, the Spaniards banned indigenous ritual ceremonies and the use of paper, which was associated with the ability to rule. The Spaniards used their own cotton based paper, which came all the way from Europe, crossing the Atlantic Ocean to fuel paper needs in the New World.

\section{The fusion of two indigenous traditions}

Despite the ban, some indigenous groups continued making bark paper in secret, keeping the tradition alive. The Otomi people, living in the village of San Pablito in the state of Puebla, have traditionally manufactured bark paper for ritual ceremonies, and continue to do so today. About 30 years ago, the Otomi joined forces with the Nahua people from the state of Guerrero, who have traditionally decorated ceramic craft pieces. Members of the two groups initially met within the markets of Mexico City while selling their respective crafts. Although their villages are far apart, the two groups produce and decorate amate products for sale, combining aspects of their traditional artwork, and continuously experimenting with new paper designs and formats. 
Bark paper was originally made only in plain, standard sized sheets $(60 \times 40 \mathrm{~cm})$, but it now comes in a variety of sizes and the end products include writing paper, booklets and lampshades. The larger sheets can even be used as wall paper or to cover furniture.

Bark paper can be found for sale in many places. Artisans travel to city markets and street stalls to sell their goods, while middlemen supply handicraft shops and bazaars. The prices vary greatly, depending on the trader and location. Within the Otomi internal market, a paper-maker may receive US\$ $0.20-0.40$ for one standard sized, plain sheet. The traders in major tourist centres charge around US\$ 15 for the decorated paper, and it can sell for up to US\$ 30 in museums and shops. The bigger and most beautiful pieces exhibited in museums, art galleries and universities sometimes cost as much as US\$ 500.

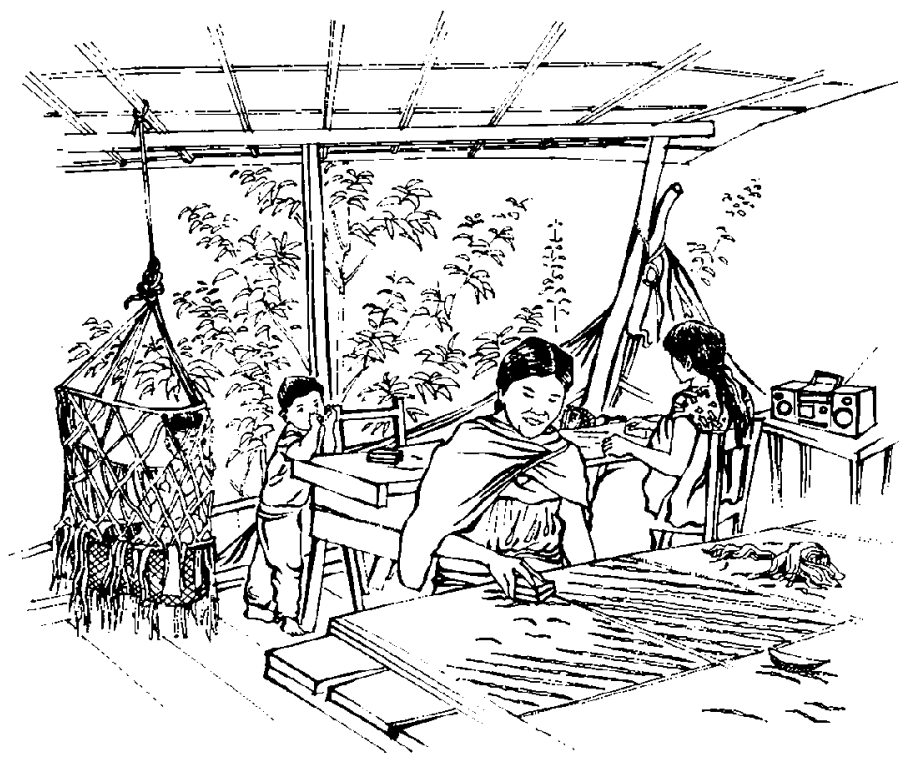

To make amate paper, artisans boil the bark and separate out the thin, soft fibres. These are arranged in a grid formation on a wooden board and are gently pounded with a grooved volcanic stone until they blend together. The use of such stones dates back to pre-Hispanic times.

\section{In need of more bark}

In the pre-Hispanic era, bark paper was made from Ficus species, belonging to the fig family. The name 'amate' in the Nahuatl language refers to both Ficus trees and bark paper. Ficus trees are still used but only occasionally nowadays, since they are slow growing and difficult to find. As demand for amate handicrafts increased, Otomi artisans searched for alternative species and Trema micrantha was found to be the most suitable - especially since it is the only one that can be debarked throughout the year.

Trema micrantha is a medium tree (up to $20 \mathrm{~m}$ in height) that grows quickly and in abundace, particularly in deforested and disturbed areas. Known as jonote in the Sierra Norte de Puebla, these trees, along with other tree species, are used to provide shade for coffee plants. The jonote trees are removed after about eight years when they start to compete with the adult coffee bushes. At that point, the region's bark collectors come in to strip the bark.

Bark collection may represent a harverster's only source of income, or a form of temporary work and extra income for expenses such as school fees. Some harvesters are wage labourers working in groups and extracting up to 3 tonnes of bark per week, but most work independently, harvesting 10 to $50 \mathrm{~kg}$ per week, with occasional help from their older children.

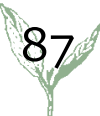




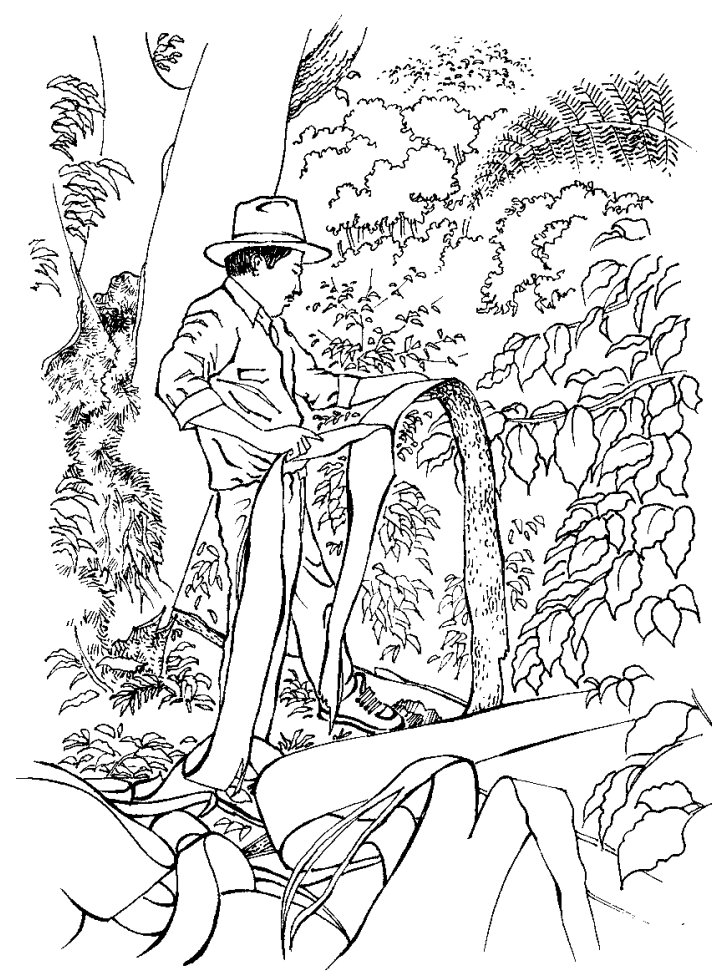

Harvesters separate the hard outer layer of bark from the soft, inner layer, which is used for making amate paper.

Bark collectors use a machete to remove long strips of bark, stretching from the base of the trunk up to the branches. They peel away the soft inner layer of bark, bending and tying it into small bundles. Several bundles are collected together into packages of 25 to $50 \mathrm{~kg}$, and these are transported by horse, donkey, bus or car, into the Otomi village of San Pablito. This journey can take up to two days.

\section{Coffee and amate - intermingled futures}

In the Sierra Norte de Puebla, most of the Trema micrantha trees can be found growing in shade-grown coffee plantations* (like the pepper trees described earlier in this volume, in the allspice case). In these plantations, the rich and varied tree cover over the coffee bushes creates forest-like vegetation, preventing erosion, keeping soils fertile, and helping native* plants and animals survive. These plantations generate cash from coffee beans and also provide fruits, herbs, fuelwood and medicinal plants. The bark harvested for amate production generates an additional source of income.

The amate industry however, is not without its problems. Recent forest laws prohibit the commercialisation of plants, like Trema, that need to be killed in order to be harvested. Also, because of the volatility and plunge in coffee prices, the future of shade-grown coffee plantations is under threat. Some land owners who have more economic resources than the Otomi and other indigenous inhabitants are extending their properties and converting their shaded plantations to crops based on sun-tolerant coffee bushes. These crops yield higher levels of coffee but also require high levels of investment in fertilisers and pesticides.

This conversion could be detrimental for the environment, the livelihoods of small holders and the production of amate. Coffee prices will need to be stabilised (allowing for the maintenance of shaded plantations), and regulations adapted regarding the extraction of bark from Trema trees. Such initiatives could help safeguard the future of amate production and those involved with it, and ensure that consumers can continue to buy this popular, traditional Mexican paper. 


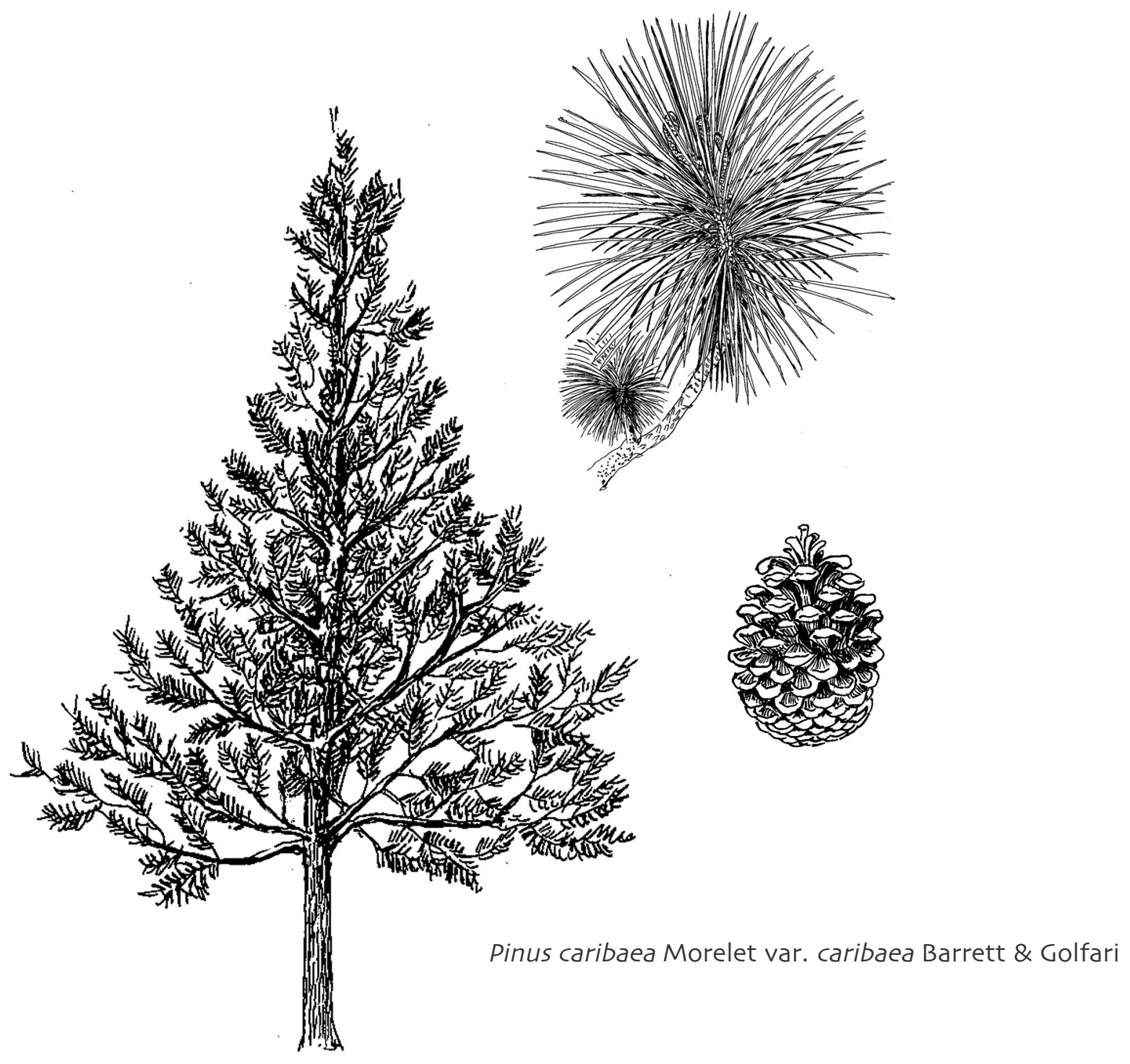

\section{Pine resin}

Cuban case by Ynocente Betancourt Figueras and Maria Josefa Villalba Fonte 


\section{Pine resin: Turpentine, paints and varnish from Cuban trees}

Next time you clean the acrylic paint off your paintbrush with turpentine, remember to thank the pine tree for its resin! Turpentine is one of the products manufactured from the thick, translucent pine resin - which is extracted from tall coniferous* (or 'cone-bearing') pine trees. Different Pinus species can be found growing naturally in various parts of the world, including Europe and Asia. Species like Pinus radiata are also grown within plantations in many countries, given the well developed market for pine products and the versatility of the timber.

In Cuba, a species called Pinus caribaea (known as 'male pine') is used for both its timber and resin. The processed pine wood is used for a wide variety of construction purposes, like making doors, windows, boats, posts, mine entranceses and furniture. Farmers also use the unprocessed round wooden poles for building houses. The resin is used as an industrial component to make products like colophony (processed resin) and turpentine, which are in high demand for the production of paints, varnishes, adhesives and disinfectants. Most of Cuba's pine resin is exported to several countries including Mexico, India and Spain. One tonne of crude resin has a market value of around US\$350, tripling in value once it is distilled.

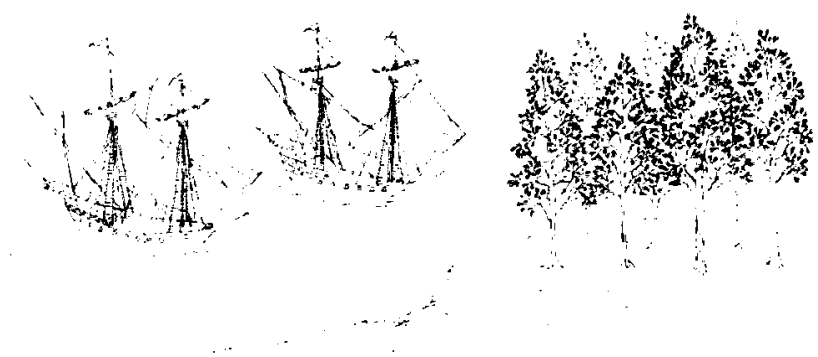

Christopher Columbus landed on the island of Cuba on 28 October 1492, during his initial westward voyage.

\section{A tropical island dotted with pines}

Pine trees in Cuba have a long history of use, stretching from pre-colonial times up until the present day. In the Caribbean, landscapes dotted with evergreen* pine trees are even known to have attracted the attention of early Spanish explorers. During his first trip to the American continent, Christopher Columbus made the following observations in his navigation journal:

"The cabin boys shouted that they could see pine forests. I looked over to the mountains and seeing [the trees] so large and marvellous, I could not but ascertain their height and straight forms ... realising that one could make vessels with an infinite number of planks and masts for the largest ships of Spain." 
Pinus caribaea is part of the natural vegetation of Cuba and is distributed mainly across Pinar del Río. This province is home to approximately 100,000 hectares of pine trees, 70 per cent of which are plantation based. Here, nearly 200 families are actively involved in the collection of pine resin, working in 'brigades'. At present, the average Cuban monthly wage is 250 pesos, but resin extractors can earn almost three times this amount. One tonne of resin fetches around 663 pesos and on average, an extractor can produce 1.5 to 2 tonnes per month.

In Cuba, industrial resin processing began in the mid-1980s. In the 17 years between 1985 and 2002, a total of 12,500 tonnes was produced - 80 per cent of which has been exported. In the first year of production the output was around 70 tonnes, increasing to almost 1,200 tonnes in 1989. Although, following the country's economic crisis in 1990, the annual output plummeted to less than 200 tonnes.

In recent years however, research efforts have focused on the processing of resin products for exportation, using nationally developed technologies. As a result, production levels have rapidly risen. In Pinar del Río, approximately 1,200 tonnes of resin have been produced per year since 2000 , and the forecast is for production to increase to around 5,000 tonnes per year. The establishment of several factories has helped to boost the volume being processed.

The fluctuations of resin production and the development of new processing technology is part of Cuba's recent economic and political history. The United States trade embargo and the collapse of Cuba's Soviet market made it very difficult to import or export products. This had serious implications, particularly in relation to health and nutrition. However, through the efforts of its citizens, and through government support and research, Cuba has managed to make its intensive agricultural and industrial activities more sustainable both socially and environmentally. The pine resin industry is one such example.

\section{Compatible extraction: Wood and resin}

Pine trees are ready for resin extraction around the same time they reach a sufficient diameter for timber logging - upwards of $20 \mathrm{~cm}$. However, the felling of trees generally takes place two to four years after the resin is tapped, to ensure a good harvest of both products: resin and pine logs.

Resin tapping involves producing a central wound in the trunk, at a height of around $1.6 \mathrm{~m}$ above the ground, along with additional, small wounds called picas, which point downwards in a ' $V$-shape'. To prepare the tree for tapping, a section of trunk, at a width of around $65 \mathrm{~cm}$, is debarked. This is the surface area that resin will be extracted from over the next 40 to 44 weeks, using a technique that allows the tree to continue living and growing until its timber is harvested. 
To stimulate the flow of resin a central wound is cut, below which a metallic funnel is hung, leading to a collection pot. Connected to the central wound, several picas are then made, each about $5 \mathrm{~mm}$ in depth and $10 \mathrm{~mm}$ in length. An additional incision is made each week to maintain the resin flow. Once the resin channels are accessed, the thick, sticky resin slowly exudes from the trunk for up to 25 hours. This is collected and deposited into $200 \mathrm{~kg}$ tanks or cans, which are transported to plant processors or export companies.

A single Pinus caribaea tree can yield about $4 \mathrm{~kg}$ of resin per year, which is equivalent to around 2 tonnes of resin per hectare. Each extractor is responsible for a production area of 6 to 10 hectares (containing 2,000 to 5,000 pine trees) - from which they collect between 15 and 30 tonnes of resin annually.

\section{A sustainable industry for Pinus caribaea}

All resin extractors are linked with the State Forestry Company, which establishes the payment system, and the Cuban Forest Commission keeps them informed about raw material prices, trade conditions and product commercialisation. The present management of pine trees and resin extraction includes the application of appropriate technologies and a focus on the conservation of pines - guaranteeing ongoing wood and resin production. The extractors benefit through stable employment and the use of techniques that ensure a high quality resin. If such conditions are maintained, this all bodes well for a sustainable future for the industry.
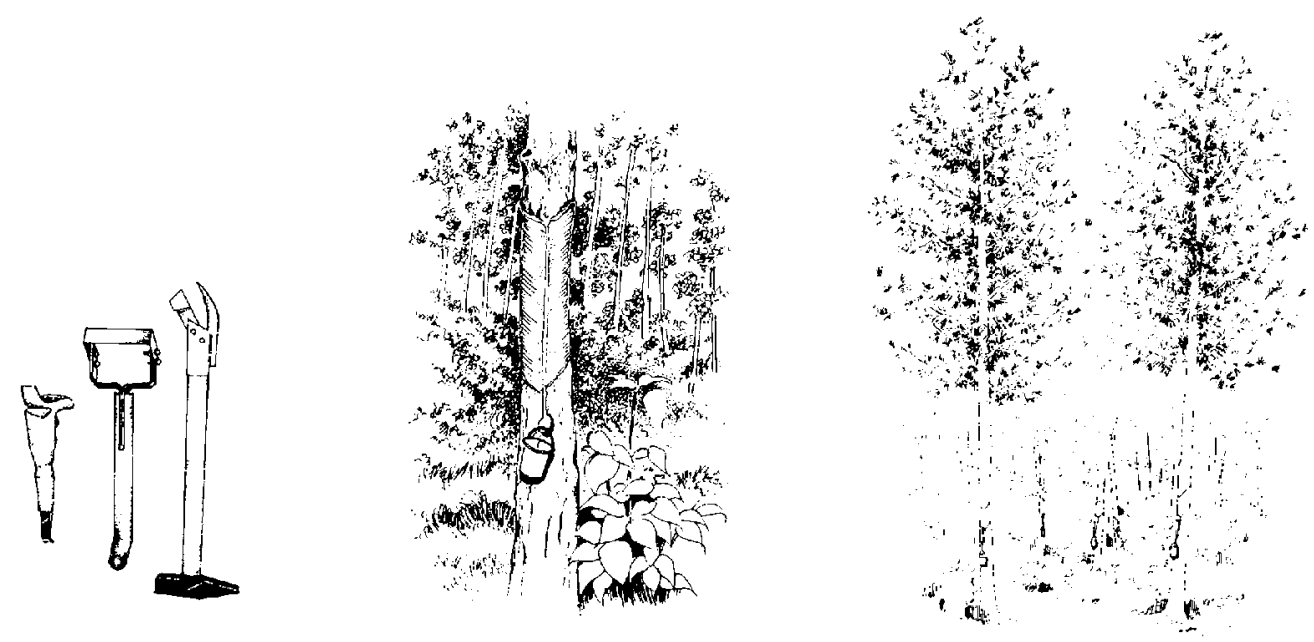

Simple tools are used to extract the pine resin, including decorticators for debarking sections of the trunk, and differently sized and shaped blades and knives for making the various incisions in the trunk. The incisions are made to stimulate the flow of resin - which is directed into specially placed funnels and collection pots. 


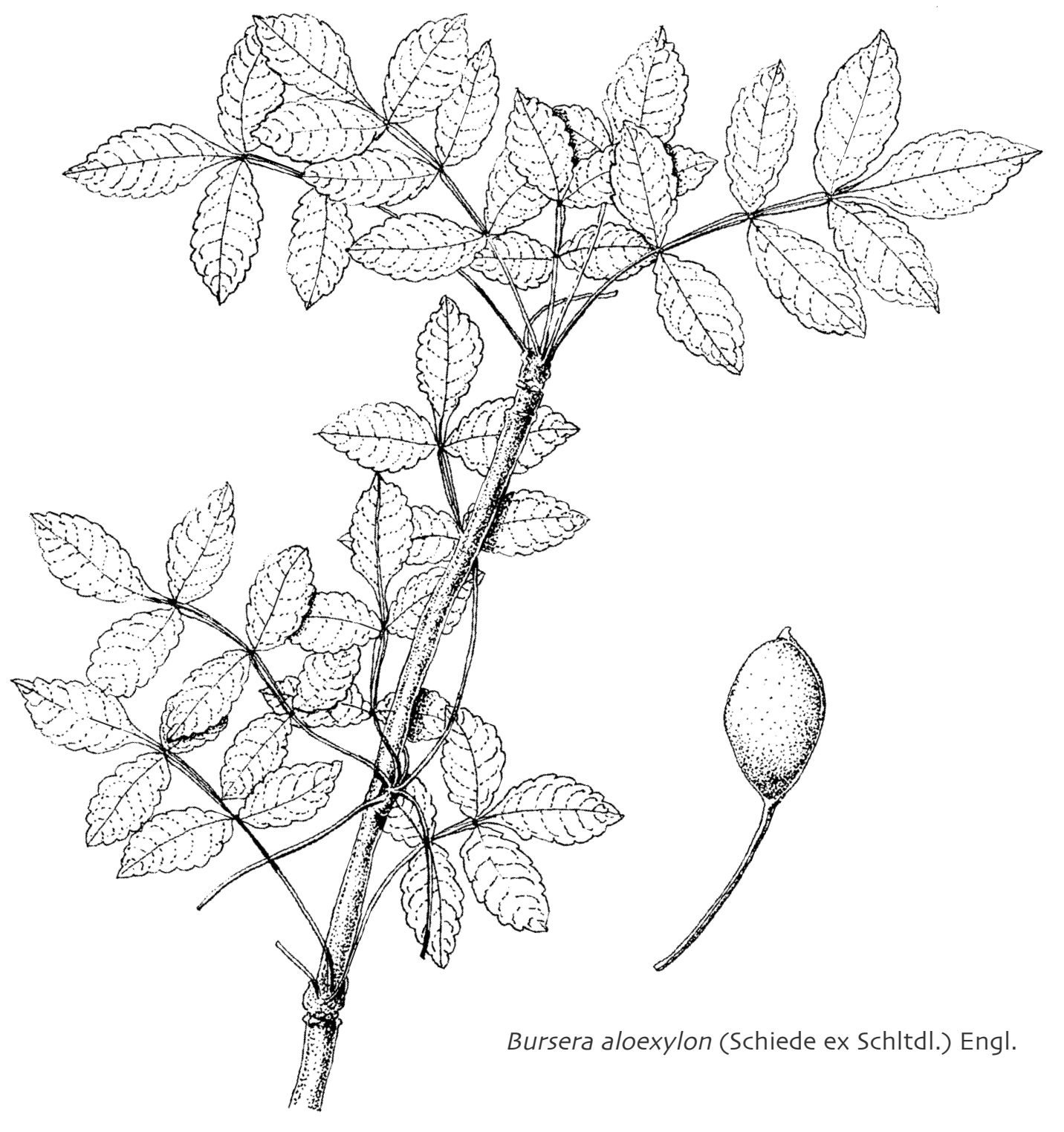

\section{Linaloe, woodcarving / essential oil}

Mexican case by Paul Hersch-Martínez 


\section{Linaloe: Wounded wood cries perfumed tears}

When you hold a wooden linaloe box from Mexico in your hands, you are in for a delightful surprise. On opening the lid of one of these beautiful lacquered handicrafts, decorated with colourful figures of rabbits, birds and flowers, you are greeted with the delicious scent of fragrant linaloe. These distinctive boxes are made from the wood of the linaloe tree, which belongs to a group of trees known as copales - valued in Mexico since pre-Hispanic times for their pleasant scents and ritual uses.

Linaloe's secret is that, unlike many copales, it exudes almost no resin when its trunk is wounded. Instead, aromatic oils accumulate within the wood, conferring a fragrant quality. This trait makes linaloe valuable for both its wood and its essential oil. In Olinala, in the state of Guerrero, where traditional

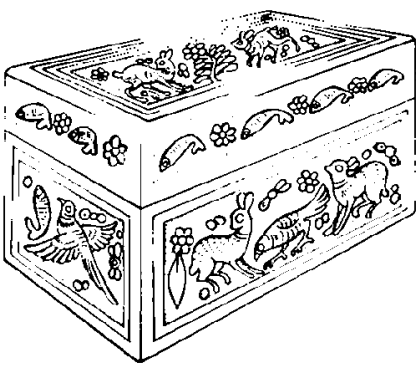

Richly decorated wooden boxes, made from linaloe timber or imbibed with linaloe essential oil, gently perfume the contents within. wooden handicrafts are manufactured, linaloe essential oil is applied to the inside of wooden boxes to give them a pleasant smell. The oil is also used to perfume clothes, and to treat headaches and scorpion bites. As the fragrance also repels moths, the aromatic wooden chests have traditionally been used for storing special clothes like wedding attire.

In the nineteenth century, linaloe wood was traded to France and England, where its oil was distilled. Mexico later commenced distillation as well, exporting the oil mainly to perfume industries in Europe and the United States throughout the first half of the twentieth century. This production of linaloe wood and oil however, involved cutting the trees down. Unfortunately, reforestation* programmes did not counterbalance the demand, and the number of linaloe trees declined dramatically, particularly in the south of Morelos and Puebla, and in the north of Guerrero.

In 1910, an English company introduced linaloe to the western region of India. Plantations were established in Bangalore and Kerala, and oil was soon being sold in India and eventually, internationally. India quickly displaced Mexico as a global supplier.

\section{Traditional extraction}

In Mexico, preparing the wood for harvesting involves a technique known as the "cove" (cala). Diagonal incisions 3-5 cm deep are made on the trunk and on thick branches. Traditionally, this procedure was carried out during the full moon at the end of the rainy season, reducing the chances of the trunks rotting in the extreme humidity. In the months that followed, the 
wounds caused oily resin to accumulate within the wood. Reddish spots would appear, known as the "map" (mapa) or "heart" (corazón), and six to seven months later, the trees would be cut down to extract the fragrant wood.

Today however, such guidelines are seldom followed largely due to the peasant harvesters' need for cash income and fewer trees being available. Increasingly, due to market pressures and declining linaloe stocks, the handicrafts are being made from the wood of pine trees or Bursera species other than linaloe, with the fragrance conferred through the later application of linaloe essential oil or synthetic equivalents.

\section{Lavish linaloe handicrafts}

Linaloe wood sold in carpentries in Olinalá, is made into different sized boxes and wooden chests within family workshops. Often the whole family will be involved in handicraft production, with some family members in charge of carpentry or varnishing, and others playing more of a commercial role. After the items are assembled and lacquered, they are decorated using two traditional methods. The foundational base for both the maque and dorado techniques is the same. An initial lacquer is prepared using a mixture of raw materials of mineral origin, with a sandy texture and yellowish colour. This tecoxtle as it is known, is combined with oil from the seeds of chía (Salvia hispanica) or linseed (Linum usitatissimum), and the resulting paste is applied to the handicraft.

The base colour is made from tlapilol powder (ground from a hard white stone), combined with a colouring agent. When this layer has been dried and polished, several coats of a ground white mineral called tolte are applied, mixed with additional

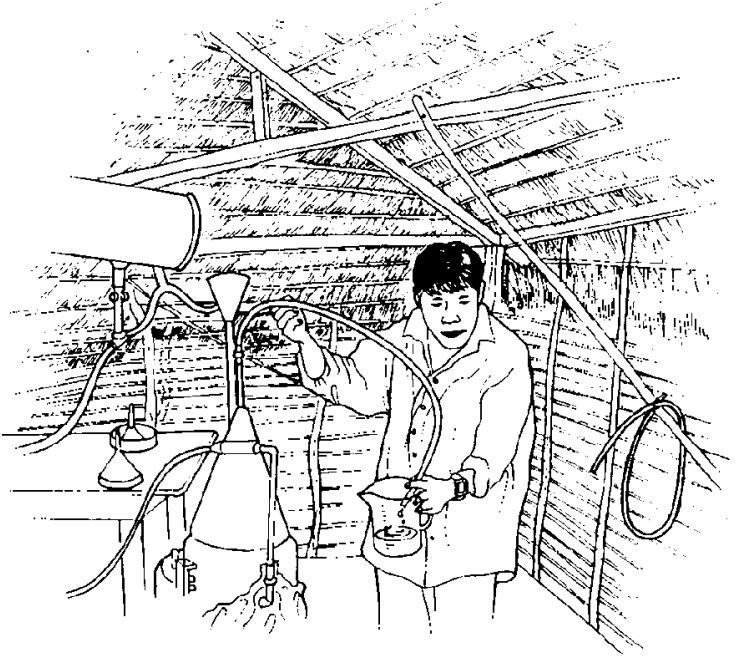

Today, oil distillation in Mexico is only carried out by a small number of peasants in Puebla and Guerrero, using very basic technology. colouring agents. After drying for two to three days, the item is polished again and decorated.

In the maque (or rayado) decorative technique, the underlying base colour is covered with several layers of lacquer (usually black, red or green), before being meticulously engraved with traditional designs. The simpler dorado technique consists of painting designs on with a brush, often dipped in gold paint - reminiscent of a time when the precious metal itself was used. These lacquer techniques were influenced by pre-Hispanic artistic traditions as well as the later introduction of Spanish aesthetics, and even Asian craftwork, which has been traded in Mexico since the sixteenth century. 


\section{Harvesters, artisans and traders}

Nowadays, a small number of peasants in the states of Puebla and Guerrero distill linaloe essential oil. The oil is used to infuse a diverse range of wooden boxes with the distinctive linaloe fragrance. Small amounts of oil are still exported to the United States and Germany although overall, distillation has declined dramatically since the middle of last century. The distillation machinery and technology in Mexico is very basic and requires high inputs of energy and money. Without technological improvements or government support, Mexico has been unable to compete with India. The technology in India allows oil to be extracted more sustainably*, from the linaloe fruits rather than the wood. In Mexico, in contrast, the linaloe trees are felled for wood and oil extraction, and as cultivation or replanting has not occurred, tree stocks have been in decline.

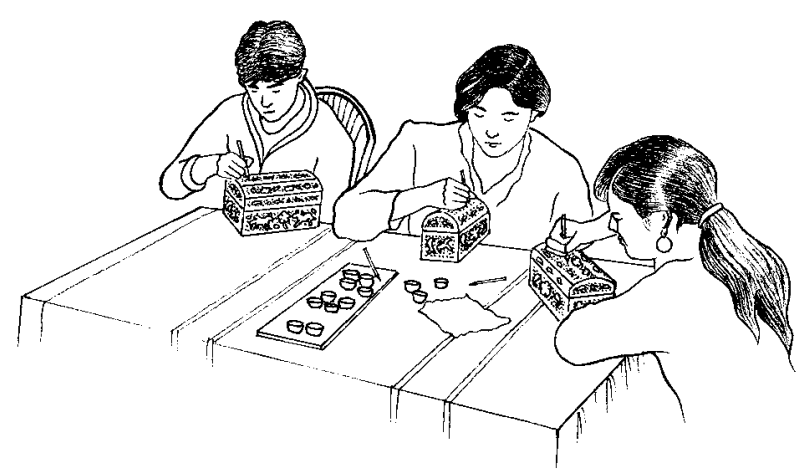

Women prepare and apply the various lacquers, polish the layers and retrace the outlines of the drawings or carved lines.

Most of the peasants that harvest linaloe carry out this activity on an occasional basis, with it generally accounting for less than 10 per cent of their overall labour. The manufacture and commercialisation of handicrafts involves around 600 families, permanently working in Olinalá. Most harvesters and artisans are indigenous* Nahua people, while the oil distillers are mainly mestizos*. Their end products are sold in regional fairs, tourist markets and urban centres, or are exported via middlemen, to Europe and the United States.

The prices increase along the commodity chain. Linaloe wood is purchased for around US\$ 9 for a section of trunk about $60 \mathrm{~cm}$ long, which can produce approximately three medium sized handicrafts. Artisans in Olinalá receive about US\$ 8 per craft piece. In a regional fair, the same piece would fetch US\$ 11, increasing to US\$ 28 in cities, and up to US\$ 37 in tourist centres or overseas markets.

Linaloe wooden handicrafts and essential oil have economic potential but realising this potential will require a sustainable wood and fruit supply. The maintenance of traditional artisan skills and quality products, and the continued manufacturing of wooden boxes and oil will require efforts to boost supplies, develop markets and new designs, and introduce modern oil distillation processes. Importantly, the peasants and artisans involved in harvesting linaloe and producing handicrafts will need to be better recognised and supported if a more sustainable industry is to be promoted. 


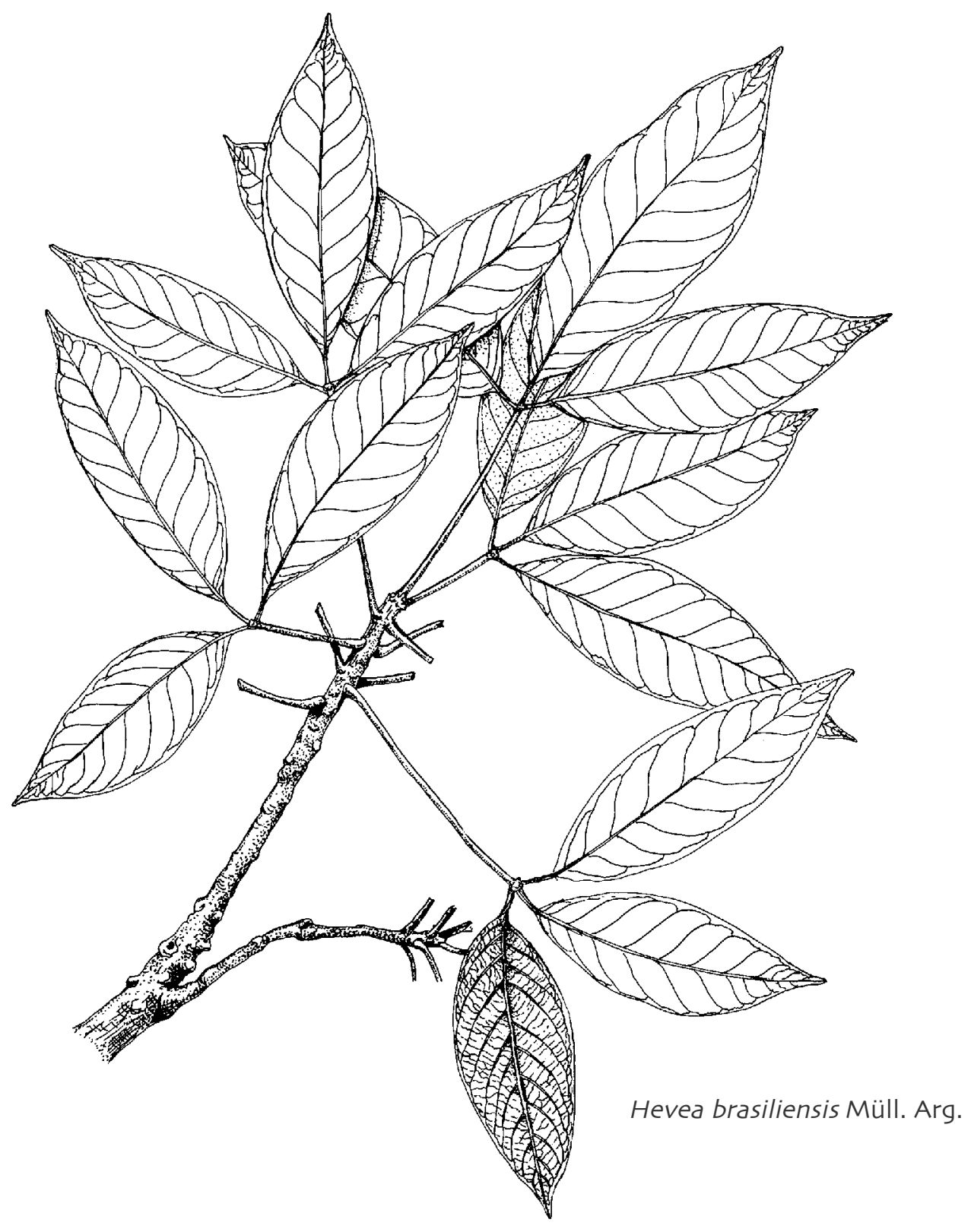

Rubber, vegetal leather

Brazilian case by Mariana Ciavatta Pantoja 


\section{Rubber trees: From the heart of the Amazon to the world of fashion}

Take a plane for several hours, or a bus for a couple of days. Then take a boat up-river for a few days. Finally, walk into the forest until you get tired. You are now in the heart of the Brazilian Amazon, astounded by the beauty and abundance of the vegetation. But living here is not easy, as the migrants who arrived at the end of the nineteenth century soon realised. Far away from everything and everyone familiar, they came to understand that survival meant learning to live off the forest's resources. They planted, hunted, and used their imaginations to create what they needed for their daily lives. Among the objects they produced, the saco encauchado (rubberized bag) became one of the most important items.

During the century that followed, the material used to make these bags was gradually improved upon and transformed into 'vegetal* leather', or couro vegetal as it is known in Brazil. Fine purses, clothes and many other items sold today in famous stores in several countries are made with this unique material - which originated in these distant forests.

\section{"Mother's milk" sustains families}

The main raw material used to produce vegetal leather is latex from the rubber tree (Hevea brasiliensis), locally called seringueira or seringa. Rubber trees have long been at the centre of life in Amazonia. Extended colonisation started when commercial rubber extraction began at the end of the nineteenth century - helping to transform Amazonia's economic, social and political profile. At one point rubber was the third most valuable Brazilian export, but as cultivation expanded in other parts of the world and synthetic alternatives were developed, the interest in natural rubber declined, as did the income it generated. In recent times however, it has been "brought back to life", with the newfound interest in rubber-derived products like vegetal leather.

Hevea brasiliensis grows naturally in Amazonian forests, and in the upper river forests of the Brazilian state of Acre an average of about one tree per hectare can be found. The trees' white latex is called "milk" by the rubber tappers, who describe the tree with reverence as "the mother that provides milk to sustain their families". There are several kinds of rubber trees and rubber plantations outside the Amazon, but this particular Amazonian species is considered ideal for producing vegetal leather.

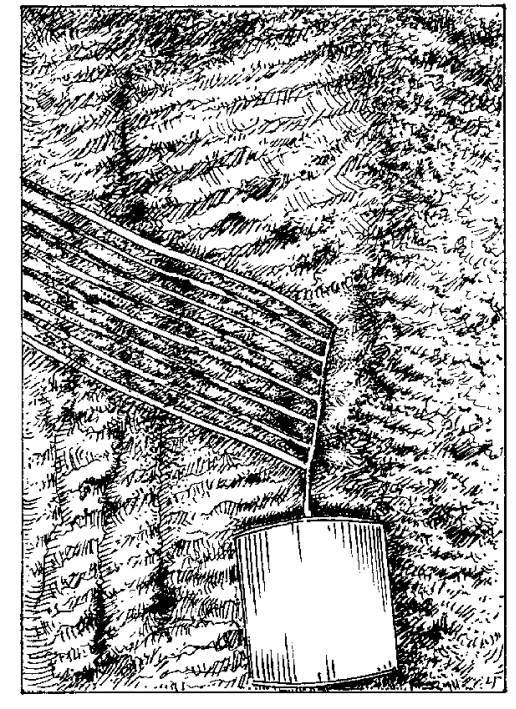

The tappers refer to the rubber latex they collect as "mother's milk" - a source of sustenance for their families. 
In the state of Acre and in the south of the state of Amazonas, there are around 40 production units, involving about 60 families and benefiting approximately 300 people. Often, all members of a household will be involved in production, especially the men, with neighbours and relatives occasionally pitching in to help. The production facilities are located within forest conservation areas, like the Alto Juruá Extraction Reserve, the Mapiá-Inauini National Forest, and the Kaxinawá Indian land of Jordão River.

\section{From tree tapping to European fashions}

The first step in making vegetal leather is to "cut the seringa road". That is, to tap a group of rubber trees (around 120) linked by a track through the forest. With a special knife the tapper "bleeds" a tree with a cut to the trunk. Each tree produces only a small amount of latex, but by the time the tapper reaches the end of the track, he may have collected ten litres or more.

The latex is mixed with an anti-coagulant* to prevent it from thickening. Individual pieces of cotton are soaked in about two litres of this mixture per item, before being smoke-cured in a volcano-like furnace fueled with firewood. The resulting heat plus the smoke from the chimney "fixes" the latex onto the fabric.

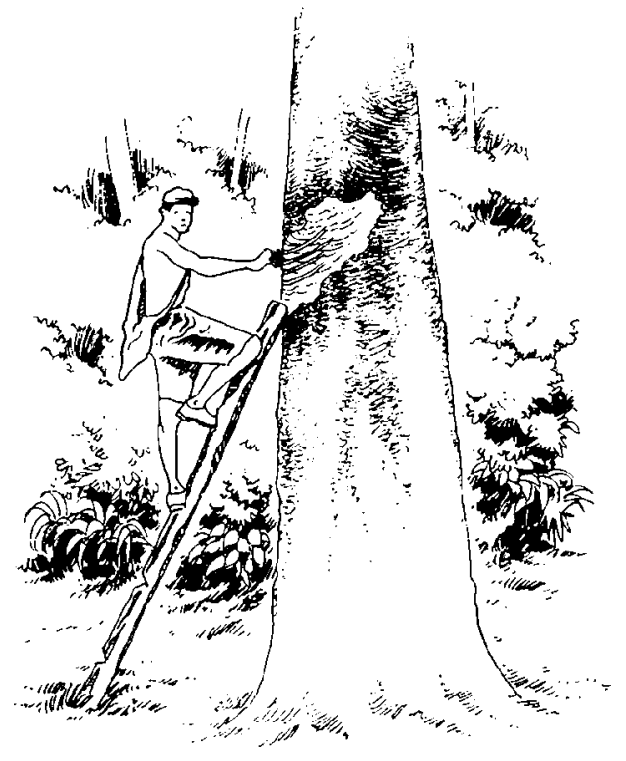

The tapper "bleeds" the tree trunks, making incisions with a special knife and collecting the latex that oozes out.
The cured fabric is placed into a firewood-fed stove and "roasted" as the tappers say. The fabric is vulcanized (i.e. treated with a sulphur compound and subjected to a temperature-controlled level of moderate heat), whereby it is transformed into vegetal leather. This step is important in determining the quality of the material. If vulcanization is done carelessly the product will have a weak consistency and unattractive appearance. Finally, each piece of fabric is cut into two sheets of vegetal leather and packed for the long trip to Rio de Janeiro.

The first leg of the journey involves the tappers taking a boat trip to the nearest town, which in the case of the Alto Juruá Extractive Reserve, can take up to three days. There, the couro vegetal is delivered to the association to which the tapper belongs, and its shipment to its final destination (i.e. Couro Vegetal da Amazônia, a company based in Rio de Janeiro) is arranged. Each pair of vegetal leather sheets sells for US\$ 3.80. The highest portion of the revenue (US\$ 0.87 or 23 per cent) is paid to the latex producer. For tappers, latex used to produce vegetal leather can generate five times as much income as the sale of pure rubber alone. Manufacturing the vegetal leather has helped to increase the income of some tappers by around 22 per cent. 
In Rio de Janeiro, the sheets undergo one last treatment, which enhances their durability and gives them a shiny appearance. The price of each sheet depends on the quality, size and other characteristics specified by the buyers. The company Couro Vegetal da Amazônia exports quality sheets to Europe, where they are sold for US\$ 10-25 each and made into garments, purses, bags, diaries, executive briefcases, footwear and a range of other products.

\section{Motorcyclists, environmentalists and consumers}

At 'FLORA', a recent annual trade show of Amazonian forest products in Rio Branco, Acre, the vegetal leather stand proved very popular. Although the prices were high, motorcycle gangs, amongst others, showed a keen interest in "greening" themselves and trading in some of their animal-derived leather goods for the forest-friendly variety. Fashionable young women bought purses and school children from families of modest means gazed with surprise at the equivalent of US\$ 100 price tags on school satchels.

Although the vegetal leather market is still being consolidated, the product is being well received, eliciting interest and support from consumers. In the export market, new possibilities for merchandise are being explored, especially in the world of fashion. In the states of Acre and Amazonas, another product similar to vegetal leather is also being produced, known as 'ecological leather'. Instead of smoke, the rubber is fixed onto the fabric using a chemical treatment.

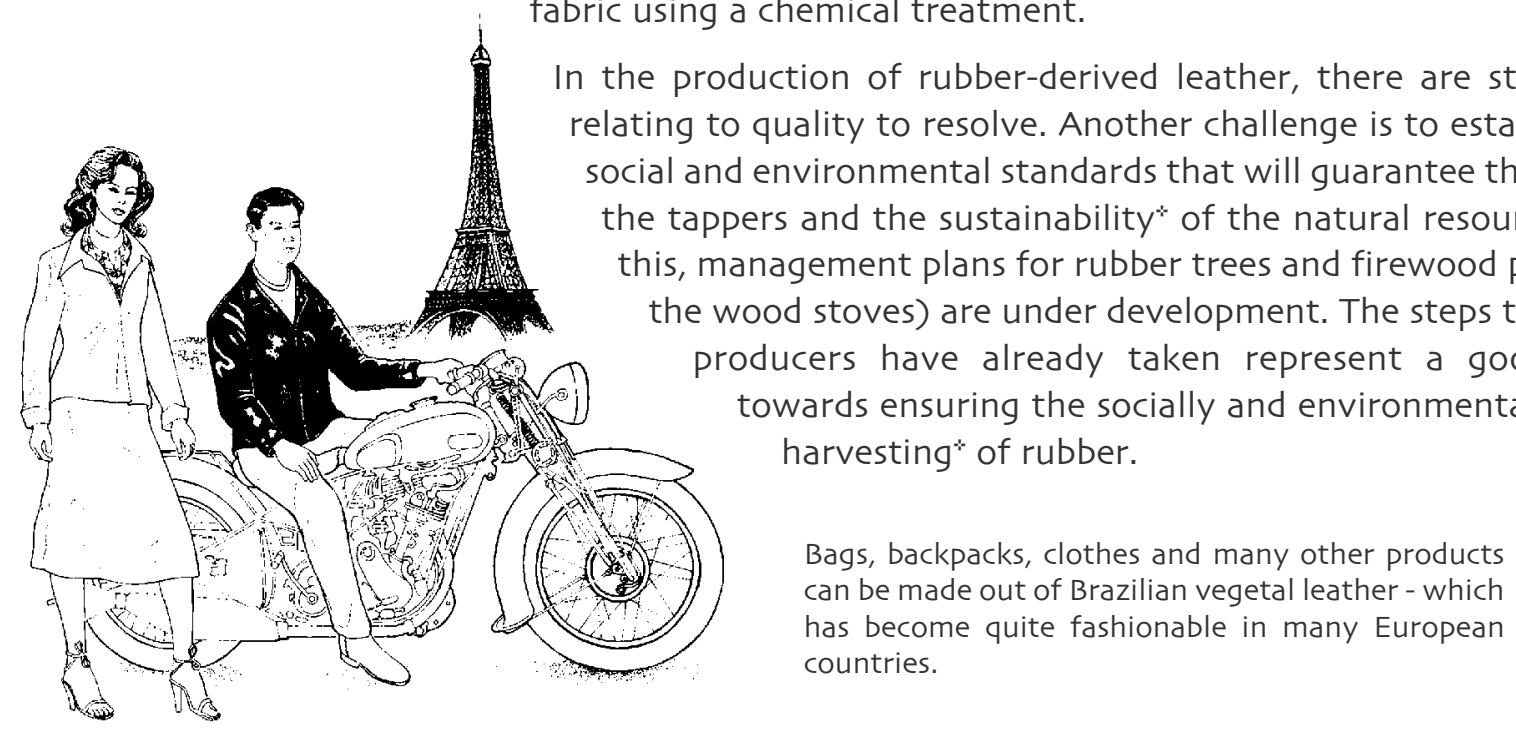




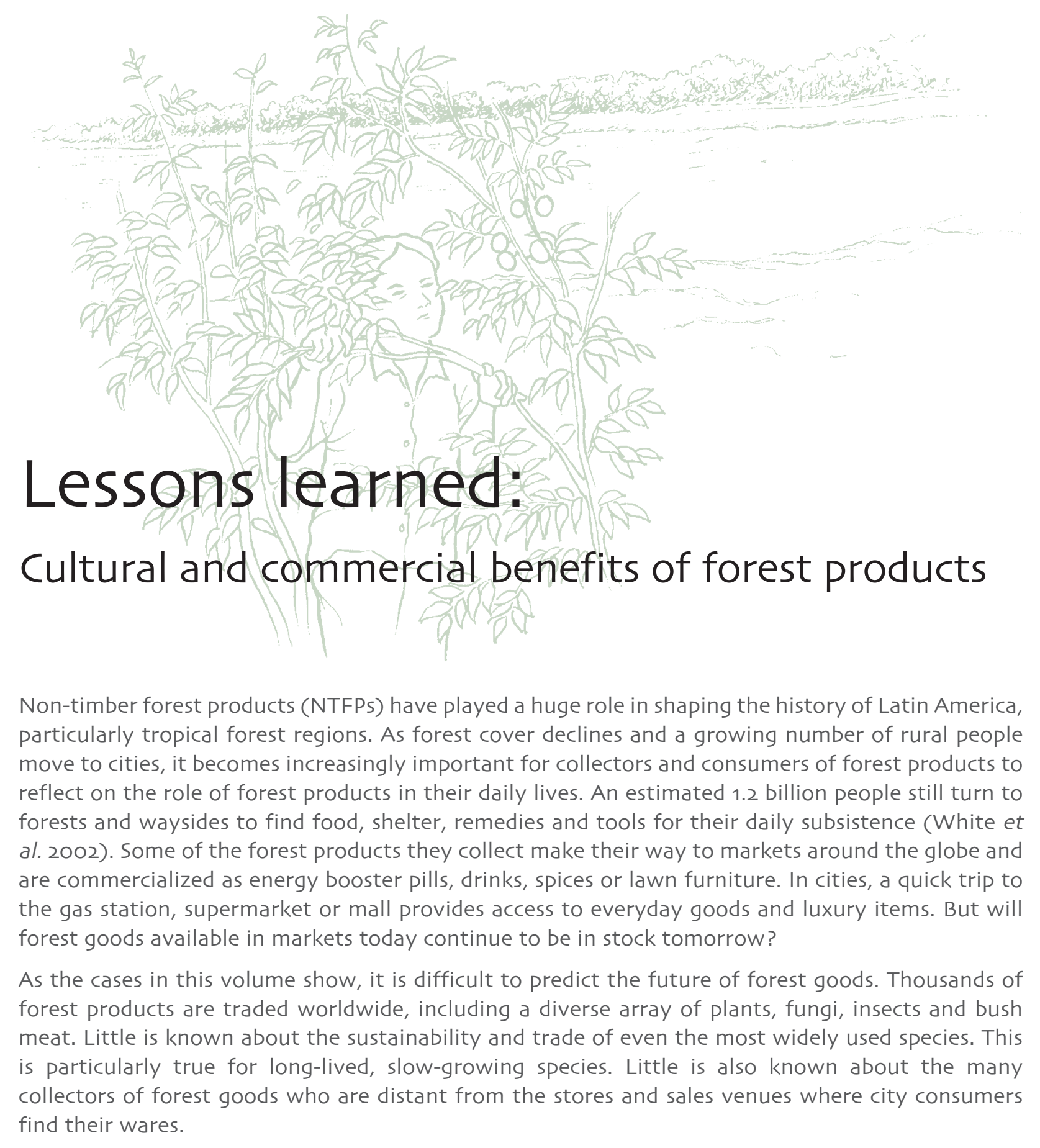


The cases in this volume demonstrate a great deal of diversity in collection, management and trade, as well as some striking similarities. By comparing cases we gain a greater understanding of the characteristics of small-scale natural resource management and the broader socio-economic context of forest resource use in Latin America.

\section{Diversity of uses}

The cases illustrate how forest products are used for direct subsistence uses such as tropical fruits and medicinal plants to luxury like Panama hats and embroidered pita fibre. The cases also illustrate how a single plant may have multiple uses. Babassu is an exceptional example with its fruit, stem, and leaves used for fuel, toys, thatching, oil and soap. The wood from the multipurpose andiroba tree serves as a building material, while its oil is used as an insect repellent and in the treatment of arthritis, worms and skin irritations. Different parts of the pupunha palm are used to construct bridges and homes and to make tools, jewelry, snacks, drinks, flour and cakes. When there exists such a variety of uses for a single species, declining populations or loss of access can have multiple consequences for the health and welfare of households associated with the forest goods or end product.

Subsistence uses (food, medicine, raw materials for domestic and agricultural utensils, building materials, etc)
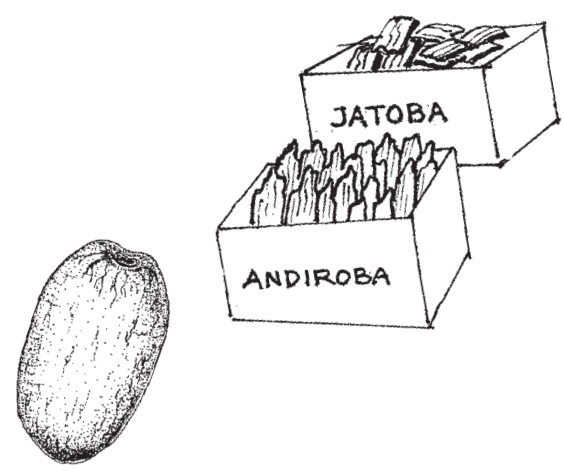

Commercial uses (exotic food, medicinals, raw material for handicrafts, components of industrial products, etc)

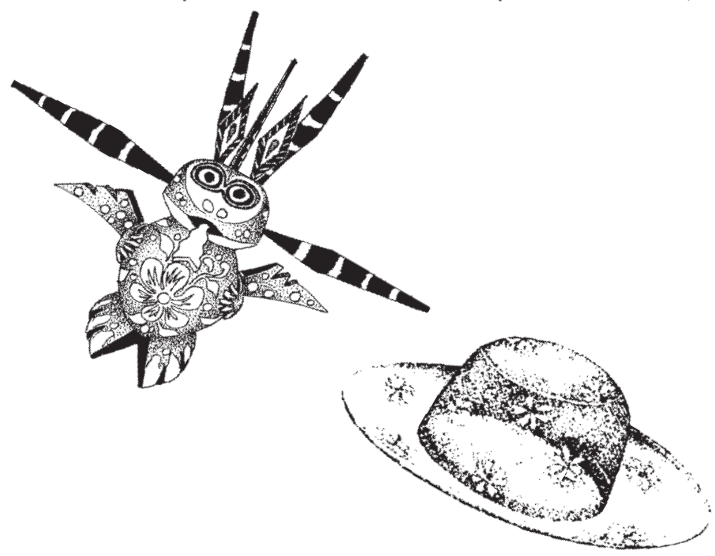

Forest products are used both to meet subsistence needs and to generate income

Non-timber forest products also play a critical role in local identity, myths and spiritual practices. Even when national or international policies indicate that harvest and management of some forest products are uneconomical, families may persist in collection - often keeping the tree as a sort of savings account. While local practices may seem unviable to outsiders, cultural ties to land and management systems often make uneconomic practices persevere. 


\section{Diversity of management practices}

To safeguard against fluctuations in supply and demand, many rural families collect and manage several resources and maintain a mosaic of land uses including crops, home gardens, fields and forests of varying ages interspersed throughout the landscape. The management of different resources and land use types often reflects centuries of experience and knowledge as well as continual innovation by farmers. At one end of the management gradient are cultivated crops, such as ipecac and pine resin grown in plantations. At the other end are goods that are extracted from forests with little to no management, such as wood for alebrijes carvings and rubber (Box 2 ).

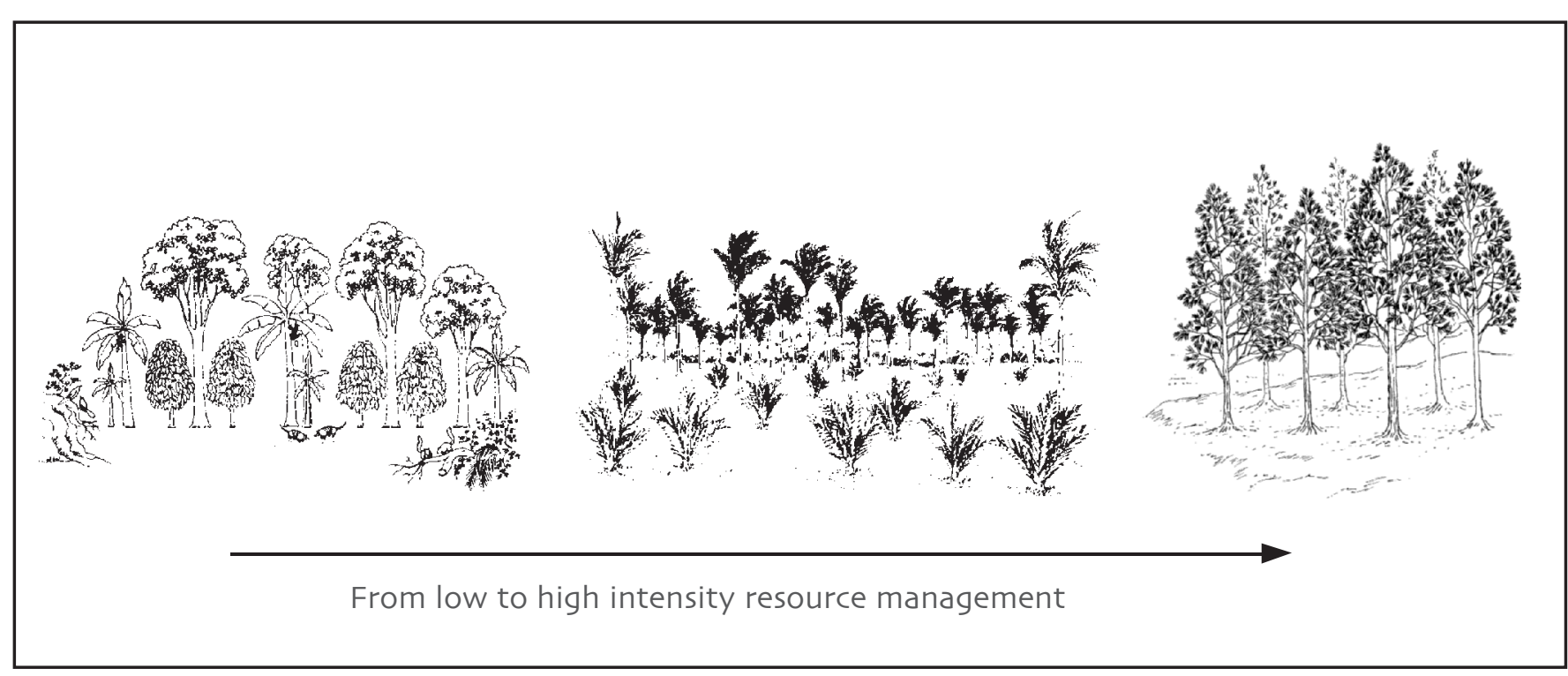

Management of many NTFPs lies somewhere between forest extraction and cultivation. They are moderately managed in forest areas, like allspice and trees for amate paper growing in shaded coffee plantations, babassu and xa'an palms in agricultural plots. Tolerating certain plants within agricultural fields, tossing edible seeds along the trailside and making a garbage heap of compost around fruit trees in a backyard, all ensure that favoured species regenerate in the proximity of one's homestead. To satisfy consumer preferences and produce enough to meet market demand, farmers may not only intensify management but modify the characteristics of certain species. For example, over centuries Native Americans have selected fruits possessing a greater percentage of pulp and favored spineless palms such as pupunha. The next table indicate the range of intensities in which some of the species in this volume are managed. 


\begin{tabular}{|c|c|}
\hline Management & Species \\
\hline $\begin{array}{l}\text { Collected from wild populations, } \\
\text { no management }\end{array}$ & $\begin{array}{l}\text { camedor leaves (Chamaedorea elegans) } \\
\text { pita fibre (Achmea magdalenae) } \\
\text { rubber (Hevea brasiliensis) }\end{array}$ \\
\hline $\begin{array}{l}\text { Encouraged, protected and otherwise managed } \\
\text { in natural forests }\end{array}$ & $\begin{array}{l}\text { palmito (Euterpe edulis) } \\
\text { uxi (Endopleura uchi) }\end{array}$ \\
\hline $\begin{array}{l}\text { Managed along with other useful native species } \\
\text { in natural vegetation }\end{array}$ & $\begin{array}{l}\text { Brazilian gingseng (Pfaffia glomerata) } \\
\text { bacuri (Platonia insignis) } \\
\text { carqueja (Baccharis trimera) } \\
\text { espinheira santa (Maytenus ilicifolia) }\end{array}$ \\
\hline $\begin{array}{l}\text { Tolerated (allowed to grow naturally and not } \\
\text { weeded out) on agricultural land }\end{array}$ & $\begin{array}{l}\text { allspice (Pimenta dioica) } \\
\text { amate paper trees (Trema micrantha) } \\
\text { babassu (Orbignya phalerata) } \\
\text { xa'an palm (Sabal yapa) }\end{array}$ \\
\hline $\begin{array}{l}\text { Cultivated in natural forests } \\
\text { Cultivated on agricultural lands in combination } \\
\text { with other cultivars }\end{array}$ & $\begin{array}{l}\text { ipecac (Psychotria ipecacuanha) } \\
\text { pupunha (Bactris gasipaes) }\end{array}$ \\
\hline Grown in monoculture plantations & pine resin (Pinus caribeae) \\
\hline
\end{tabular}

The gradient of management practices described is reflected in a degree of reliance on forest resources. Some families rely almost completely on wild resources, while others diversify their activities, including collection and sale of several forest goods. Both men and women harvest forest products, although men often dominate in harvesting certain products like camedor leaves, palmito, pita fibre and rubber, while women have a very important role in processing products such as alebrijes wood carvings, amate paper and medicinal tea from carqueja leaves.

\section{The value of NTFPs for diverse sectors of society}

Estimates that $80 \%$ of the world's population uses forest resources to meet its health care needs (Farnsworth et al. 1985) indicate the critical importance of these resources for subsistence livelihoods and direct use. Forest goods also allow people to survive seasonal hardships and to endure during times of conflict. In many cases, forest goods provide supplementary income in addition to revenue generated from agricultural or other sources. For example, the harvest of bacuri, mamey and uxi may be scheduled around other work demands and the fruiting season. The cases of babassu, camu-camu and palmito show that even when harvesters receive relatively little revenue, NTFPs can represent their most important source of cash income. Rural families may use the income generated from the sale of raw or manufactured material to cover important expenditures such as school fees or medical treatment. 
Trade of NTFPs occurs in local, regional and international markets. Much of the local and regional trade in forest goods occurs during the darkness of predawn on boats, along rivers and in back alleys on the periphery of outdoor markets. Local markets allow rural and urban populations sales venues that are accessible, stable and easier to negotiate and less risky than international trade. Such immense - and informal - trade goes undetected by national accounting systems.

Statistics on the export trade in NTFPs exist, but generally they underreport volumes and include only a few highly valued commodities such as palmito. In spite of the lack of inventories of all levels of trade in NTFPs, available statistics do indicate rising global trade. This development is particularly notable in the commercialisation of medicinal plant products, which is skyrocketing; in 1999 trade in phytotherapeutics and botanicals reached an estimated US\$ 20 billion (Gruenwald 2000).

In Latin America, current conditions favoring trade in NTFPs include rapid growth in urban populations, increased market access and rising tourism. Some products, which were used for domestic purposes in rural areas, have recently become traded more broadly. Once used for thatching Maya houses, leaves of xa'an palms have become commercially used construction materials to give a rustic appearance to tourist hotels in the Mexican Caribbean. Amate paper, in the past used for ceremonial purposes in Mexico, is now sold as souvenirs. Rubber from Amazonia is now processed to create costly handbags found in fashionable shops in Paris and New York.

\section{Responses to rising demand}

How do collectors respond to increasing market opportunities? The cases in this volume show that, when target species become scarce, collectors use various strategies to meet rising demand. In many cases they begin to search farther afield, going greater distances to gather the resources (alebrijes, Brazilian ginseng, linaloe). In the case of palmito in the Atlantic forest of Brazil, overexploitation of wild palms has led to widespread local extinction. In other cases, collectors search for plants or animals that can substitute for the original resource. As the original palm species for extracting palmito (Euterpe edulis) disappears from the Atlantic forest, other palm species (Euterpe oleraceae and Bactris gasipaes) serve as new sources. For the last three decades in Mexico, artisans producing amate paper and linaloe boxes have substituted various tree species for the preferred Ficus and Bursera spp., respectively. To add weight and volume, collectors may trick the unknowing buyer by substituting bark and leaves of more common species for rarer ones, like in the espinheira santa case.

Another response to increasing scarcity is to intensify management of the species. In Asia, centuries of trade have led to intensified management of many commonly traded forest goods including bamboo, cardamom and rattan. In Africa and Latin America, many of the most widely traded forest goods are not yet intensively managed or cultivated but still sourced from forests. Cultivation is a more viable option with fast growing herbaceous species and shrubs than with slow growing trees. The Latin American products illustrate various degrees of intensification of management with some species, such as $u x i$, undergoing experimental intensification by farmers. In spite of attempts to cultivate, 15 of the 24 products surveyed by CIFOR's collaborators, continue to be collected from wild sources, indicating that extractivism is still an important harvesting model for Latin America. 


\section{Effects of trade}

Contrary to what most consumers may think, growing demand for forest products does not always result in improved incomes for rural collectors, processors or traders. Many forest goods are undervalued and the price producers receive is extremely low, poorly compensating them for the costs of production.

Increasing demand and more profitable commercialisation can have the following effects:

- Lessen supply and access to forest resources for families who depend on forest goods for their own use;

- Diminish access to forest land or specific forest resources by small farmers who lack ownership of land or economic conditions to invest;

- Favor new and intensified management practices that tend to involve a new set of farmers with greater access to land and technologies, thereafter displacing original users;

- Increase the division of tasks and the possible abandonment of traditional harvesting and processing techniques.

On the other hand, increased trade has resulted in:

- More income for some rural and urban families;

- Improved education and health care;

- Enhanced cultural pride and self esteem;

- Broadened economic options, which may allow families to remain in rural areas.

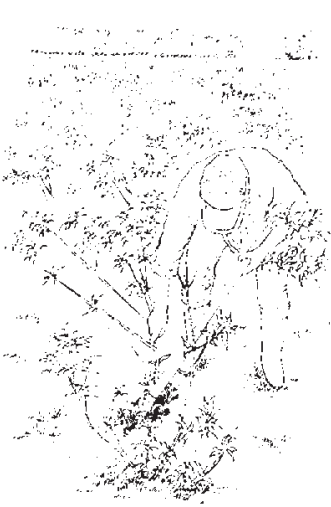

Pressure over resources Harvesting techniques Resource management

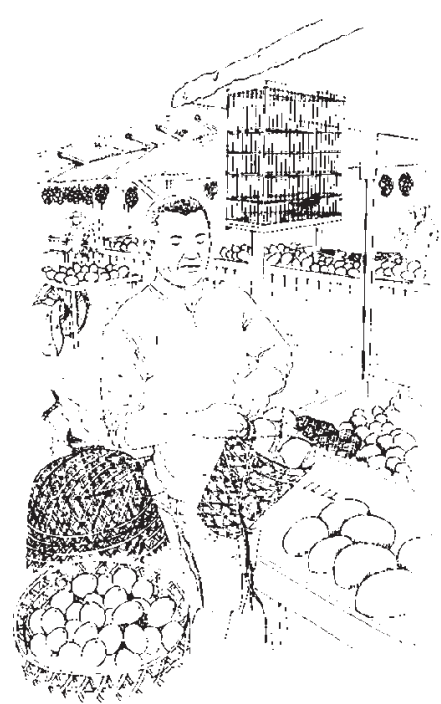

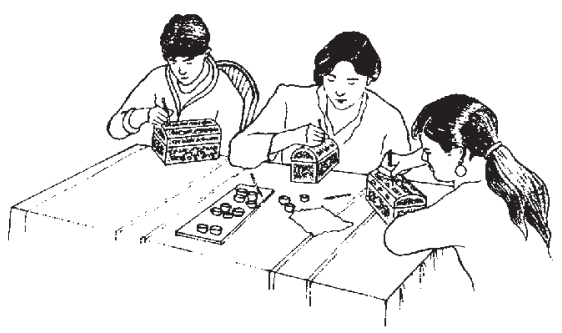

Changes in processing technology Division of work

Quality and quantity of production Transporting and marketing

When demand for a forest product increases, many changes can occur in relation to harvesting, processing and marketing 


\section{Our knowledge of non-timber forest products}

Case studies illustrate that forest goods are important for their role in subsistence, trade and the sense of place and cultural identity that they offer to hundreds of millions of rural and urban families worldwide. The ability of a forest resource to continue to meet these needs, however, depends upon sustainable harvesting and management practices.

Because of the complexity and potentially negative consequences of increased trade in forest goods for small producers, plans to enhance commercialization or to intensify production of forest goods need to bear in mind the wide range of potential impacts. Forest products are often harvested unsustainably and their value is rarely shared in an equitable way among the people involved in collection, processing and trade.

Access to information about management, use and marketing of forest products is an important part of raising awareness and can help to ensure a longer-term future for both the forest products and the people who depend upon them. At the international level, work is needed to promote synergies among organizations within and outside of the forestry sector and to improve the capacity of national organisations to include the multidimensional contribution of forests in their research and development programmes. The complexity of NTFPs signifies that it is difficult to generalize about them. However, based on the Latin American cases presented in this volume, a number of observations can be made:

\section{Trade}

- Global interest in forest goods has fluctuated since the colonial era, with some products losing importance (barbasco, chicle, rubber) and others gaining importance (crafts, fruits, medicines). Europeans discovered the New World because of their intense interest in seeking and dominating trade in forest goods such as spices and condiments.

- Boom-bust cycles characterise some internationally traded NTFPs (barbasco, chicle, rubber). Forest products with high-volume export trade are often overexploited, leading to replacement with natural or industrial substitutes or cultivation. This is not the case for the majority of locally and regionally traded products that tend towards more stable supply and demand and continue to be extracted from the wild.

- Global interest in botanicals and forest goods is rising and expected to continue to rise throughout the twenty-first century. Few have been adequately studied and many may be threatened by habitat loss.

- The potential effects of commercialisation should be assessed before promoting trade of forest products. Among other main problems, increased demand can marginalise those with less power - women, children and the elderly - who may receive few benefits or even lose access to forest resources. 


\section{Culture and subsistence}

- Interchange of knowledge. Trade in forest goods in Latin America has involved centuries of interchange of experiences and knowledge regarding processing and management.

- Non-commercial values are critical, particularly for the health and welfare of rural and urban poor populations, but governments, research organizations and donors frequently overlook these needs.

- Cultural uses of forest resources play a prominent role in the life of people from all classes of both rural and urban environments. When resources gain value, they are often appropriated by more powerful interests. Cultural values associated with forest goods are often driving forces for their use and management and merit increased attention.

\section{Ecology}

- The greatest threat to the majority of the Latin American NTFPs studied is not overexploitation by collectors but deforestation (agricultural expansion, logging, mining, ranching).

- Locally crafted innovations in resource management are often the result of long-term experimentation by rural people and could play a central role in sustainable sourcing, use and trade of forest goods.

- Lack of knowledge about ecology, use, trade and value of NTFPs can prohibit their meaningful inclusion in forest management, poverty reduction and related programs. 


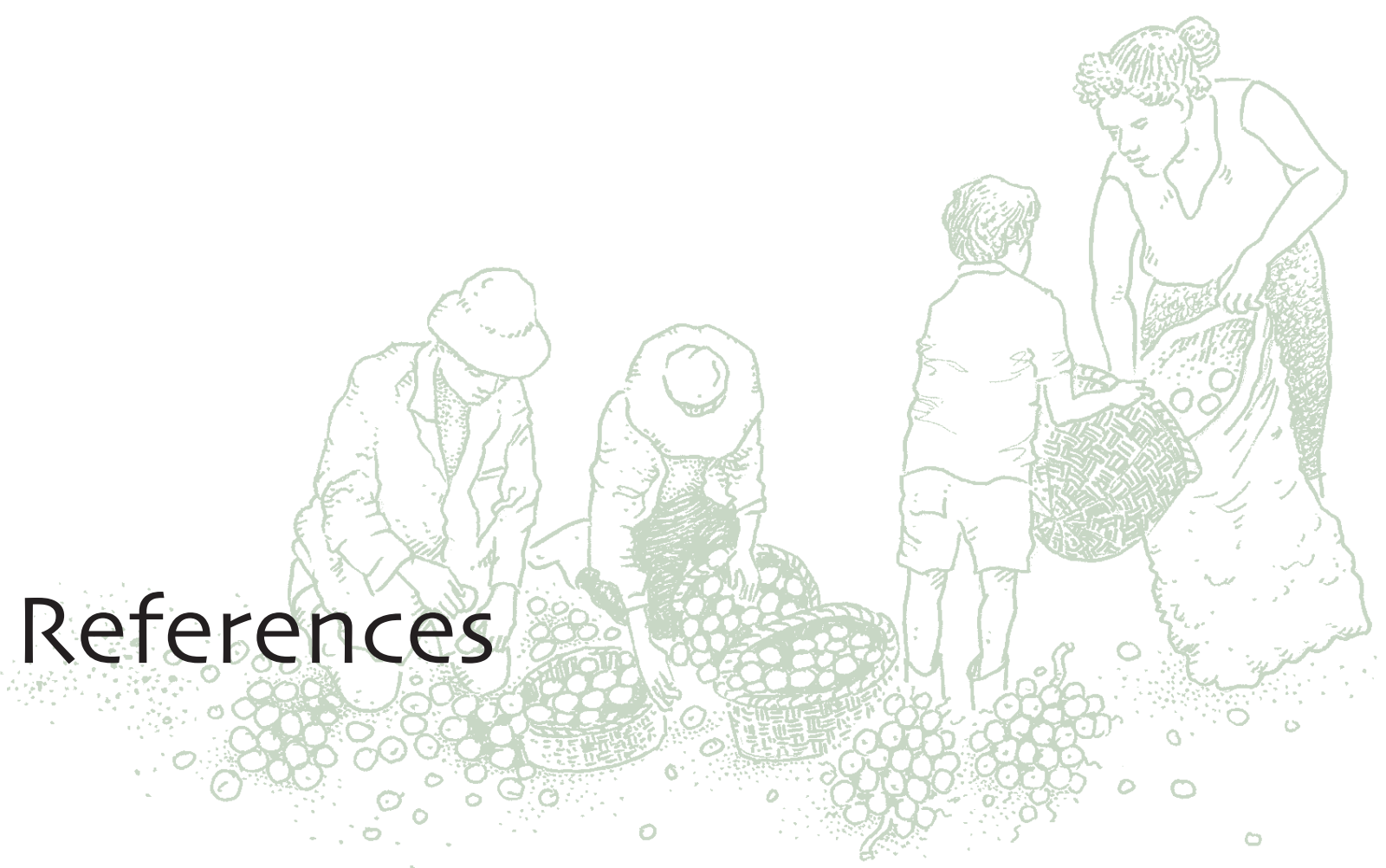

\section{General}

Alexiades, M.N. y Shanley, P. 2004 Productos forestales, medios de subsistencia y conservación: Estudios de caso sobre sistemas de manejo de productos forestales no maderables. En: Alexiades, M.N. y Shanley, P. (editores) 2004 Productos Forestales, Medios de Subsistencia y Conservación: Estudios de Caso Sobre Sistemas de Manejo de Productos Forestales No Maderables. Volumen 3 América Latina. Centro para la Investigación Forestal Internacional (CIFOR), Bogor, Indonesia.

Balée, W. 1994 Footprints of the forest: Ka'apor ethnobotany. The historical ecology of plant utilization by an Amazonian people. Columbia University Press, New York.

Bennett, B.C. 1992 Plants and people of the Amazonian rainforests: The role of ethnobotany in sustainable development. Bioscience 42: 599-607.

Campbell, B.M. and Luckert, M. (eds.) 2002 Uncovering the hidden harvest: Valuation methods for woodland and forest resources. People and Plants Conservation Series. Earthscan, UK and USA. 262p.

Cunningham, A.B. 2001 Applied Ethnobotany: People, plant use and conservation. People and Plants Conservation Manuals. Earthscan, UK and USA. 300p. 
Duke, J.A. and Vasquez, R. 1994 Amazonian ethnobotanical dictionary. CRC Press, USA. 215P.

Farnsworth, N.R., Akerele, O., Bingel, A.S., Soejarto, D.D. and Guo, Z. 1985 Medicinal plants in therapy. Bulletin of the World Health Organization 63(6):965-981.

Gruenwald, J. 2000 The supplemental markets in the US and Europe. Nutraceuticals World. JulyAugust.

Heywood, V.H. 1978 Flowering plants of the world. Oxford University Press, Oxford, UK.

Laird, S. (ed.) 2002 Biodiversity and traditional knowledge: Equitable partnerships in practice. People and Plants Conservation Series. Earthscan, UK and USA. 504P.

Langman, I. 1964 A selected guide to the literature on the flowering plants in Mexico. The University of Pennsylvania Press, Philadelphia, PA., USA.

Pennington, T.D. y Sarukhán, J. 1998 Árboles tropicales de México. Manual para la identificación de las principales especies. Universidad Nacional Autónoma de México (UNAM)/Fondo de Cultura Económica (FCE), México.

Pio Corrêa, M. 1984 Dicionário das plantas úteis do Brasil. Distrito Federal, Ministério da Agricultura, Instituto Brasileiro de Desenvolvimento Florestal (IBDF).

Ruiz-Pérez, M. and Byron, N. (eds.) 1999 A methodology to analyze divergent case studies of nontimber forest products and their development potential. Forest Science 45(1): 1-14.

Scherr, S.J., White, A. and Kaimowitz, D. 2004 A new agenda for forest conservation and poverty reduction: Making markets work for low-income producers. Forest Trends/Center for International Forestry Research (CIFOR)/The World Conservation Union (IUCN).

Shanley, P. e Medina, G. (eds.) (in press) Frutíferas e plantas úteis na vida Amazônica. CIFOR e Instituto do Homem e Meio Ambiente da Amazônia (IMAZON). 278p.

Shanley, P., Pierce, A.R., Laird, S. and Guillén, A. (eds.) 2002 Tapping the green market: Certification and management of non-timber forest products. People and Plants Conservation Series. Earthscan, UK and USA. 456p.

White, A. and Martin, A. 2002 Who owns the world's forests? Forest tenure and public forests in transition. Forest Trends/Center for International Environmental Law. 30p. 


\section{Fruits}

Balick, M.J. and Pinheiro, C.U.B. 1993 Babassu. In: Clay, J.W. and Clement, C.R. (eds.) Selected species and strategies to enhance income generation from Amazonian forests. Food and Agricultural Organization of the United Nations (FAO), Italy, Rome.

Cavalcante, P.B. 1991 Frutas comestíveis da Amazônia. Edições Cejup, Belém, Pará. 279p.

Clement, C.R. e van Leeuwen, J. 2004 Sub-utilização da pupunha (Bactris gasipaes Kunth) na Amazônia Central: História, cadeia de produção, e implicasões para o desenvolvimento e conservação. En: Alexiades, M.N. y Shanley, P. (eds.) 2004 Productos forestales, medios de subsistencia y conservación: Estudios de caso sobre sistemas de manejo de productos forestales no maderables. Volumen 3 - América Latina. Centro para la Investigación Forestal Internacional (CIFOR), Bogor, Indonesia.

May, P.H. 1990 Palmeiras em chamas: Transformação agrária e justiça social na zona de babaçu. Empresa Maranhense de Pesquisa Agropecáuria (EMAPA), Finaciadora de Estudios e Projetos (FINEP) and Fundação Ford. São Luís, Maranhão, Brasil.

Medina, G. e Ferreira, S. 2004 Bacuri (Platonia insignis Martius): O fruto Amazônico que virou ouro. En: Alexiades, M.N. y Shanley, P. (eds.) 2004 Productos forestales, medios de subsistencia y conservación: Estudios de caso sobre sistemas de manejo de productos forestales no maderables. Volumen 3 - América Latina. Centro para la Investigación Forestal Internacional (CIFOR), Bogor, Indonesia.

Ministério da Indústria e Comércio/Secretaria de Tecnologia Industrial (MIC/STI) 1982 Mapeamento do potencial das ocorrências de babaçuais. Estado do Maranhão, Piauí e Goiás. Brasília, Brasil.

Mora-Urpí, J., Weberand, J.C. and Clement, C.R. 1997 Peach palm Bactris gasipaes Kunth. Promoting the conservation and use of underutilized and neglected crops. Publication No. 20. International Plant Genetic Resources Institute (IPGRI)/Institute of Plant Genetics and Crop Plant Research (IPK), Rome, Italy. 83p. (http://www.ipgri.cgiar.org/publications/pdf/155.pdf)

Morten, B.H. 2001 The natural extraction of the native fruit from Myrciaria dubia (camu camu) and its potential for cultivation in the Peruvian Amazon. The Royal Veterinary and Agricultural University, Copenhagen, Denmark. 59p.

Morton, J.F. 1987 Fruits of warm climates. Published by Julia F. Morton, Miami, USA. 
Nava-Cruz, Y. y Ricker, M. 2004 El Zapote Mamey (Pouteria sapota (Jacq.) H. Moore y Stearn), un fruto de la selva Mexicana con alto valor comercial. En: Alexiades, M.N. y Shanley, P. (eds.) 2004 Productos forestales, medios de subsistencia y conservación: Estudios de caso sobre sistemas de manejo de productos forestales no maderables. Volumen 3 - América Latina. Centro para la Investigación Forestal Internacional (CIFOR), Bogor, Indonesia.

Oyen, L.P.A. 1991 Pouteria sapota (Jack) H.E. Moore \& Stearn. En: Verheij, E.W.M. y Coronel, R.E. (eds.) Plant resources of South-East Asia 2: Edible fruits and nuts, P. 259-262. Pudoc Scientific Publishers-DLO, Wageningen, The Netherlands.

Pennington, T.D. 1990 Flora Neotropica Monograph 52: Sapotaceae. The New York Botanical Garden, New York, USA.

Peters, C.H.M. y Vásquez, M.A. 1987 Estudios ecológicos de camu-camu (Myrciaria dubia). Producción de frutos en poblaciones naturales. Acta Amazónica, Manaus, Brasil (16/17): 161-173.

Pinedo, P.M. 2002 Variación del contenido de vitamina C de camu-camu silvestre en Loreto, Perú. Instituto de Investigaciones de la Amazonía Peruana. Programa de Ecosistemas Terrestres. 7P.

Pinedo, P.M. y de Jong, W. 2004 Camu-camu (Myrciaria dubia McVaugh (H.B.K)) un arbusto Amazónico de áreas inundables con alto contenido de vitamina ( en Loreto, Perú. En: Alexiades, M.N. y Shanley, P. (eds.) 2004 Productos forestales, medios de subsistencia y conservación: Estudios de caso sobre sistemas de manejo de productos forestales no maderables. Volumen 3 - América Latina. Centro para la Investigación Forestal Internacional (CIFOR), Bogor, Indonesia.

Pinheiro, C.U.B. 2004 A palmeira babaçu (Orbignya phalerata Martius) e sua exploração na região dos cocais, Maranhão, nordeste do Brasil. En: Alexiades, M.N. y Shanley, P. (eds.) 2004 Productos forestales, medios de subsistencia y conservación: Estudios de caso sobre sistemas de manejo de productos forestales no maderables. Volumen 3 - América Latina. Centro para la Investigación Forestal Internacional (CIFOR), Bogor, Indonesia.

Pinheiro, C.U.B. and Frazão, J.M.F. 1995 Integral processing of babassu palm (Orbignya phalerata, Arecaceae) fruits: Village level production in Maranhão, Brazil. Economic Botany 49(1): 31-39.

Ricker, M., Mendelsohn, R.O., Daly, D.C. and Angeles, G. 1999 Enriching the rainforest with native fruit trees: An ecological and economic analysis in Los Tuxtlas (Veracruz, Mexico). Ecological Economics 31: 439-448. 
Ricker, M., Siebe, C., Sanchez, S.B., Shimada, K., Larson, B.C., Martinez-Ramos, M. and Montagnini, F. 2000 Optimizing seedling management. Pouteria sapota, Diospyros digna and Cedrela odorata in Mexican rainforest. Forest Ecology and Management 139: 63-77.

Shanley, P. e Gaia, G. A fruta do pobre se torna lucrativa: A Endopleura uchi Cuatrec. em áreas manejadas próximo a Belém, Brasil. En: Alexiades, M.N. y Shanley, P. (eds.) 2004 Productos forestales, medios de subsistencia y conservación: Estudios de caso sobre sistemas de manejo de productos forestales no maderables. Volumen 3 - América Latina. Centro para la Investigación Forestal Internacional (CIFOR), Bogor, Indonesia.

Weiss, D.K. 1998 Un estudio del mercado mundial para el camu-camu. Winrock International. Proyecto de Desarrollo Alternativo USAID/CONTRADROGAS. Convenio United States Agency for International Development USAID-Instituto Nacional de Desarrollo (INADE). 18p.

\section{Leaves}

Aguilar de Tamariz, M. 1988 Tejiendo la vida. Las artesanías de la paja toquilla en el Ecuador. Centro Interamericano de Artesanías y Artes Populares (CIDAP), P 4, 22, 23 y 27.

Ahmed, M.S., Fong, H.H.S., Soejarto, D.D., Dobberstein, R.H. and Waller, D.P. 1981 Highperformance liquid chromatographic separation and quantitation of maytansinoids in Maytenus ilicifolia. Journal of Chromatography 213: 340-344.

Alarcón, R. y Burbano, M.F. 2004 Uso de la paja toquilla (Carludovica palmata Ruiz \& Pavón), en la elaboración de sombreros en tres comunidades de la provincia de Manabí, Ecuador. En: Alexiades, M.N. y Shanley, P. (eds.) 2004 Productos forestales, medios de subsistencia y conservación: Estudios de caso sobre sistemas de manejo de productos forestales no maderables. Volumen 3 - América Latina. Centro para la Investigación Forestal Internacional (CIFOR), Bogor, Indonesia.

Alarcón, R. y Londoño, T. 1997 Manejo en vivero de la paja toquilla, Carludovica palmata (R\&P), en la zona de influencia del Parque Nacional Yasuní. En: Mena, P.A., Soldi, A., Alarcón, R., Chiriboga, C. y Suárez, L. (eds.) 1997 Estudios Biológicos para la Conservación, Diversidad, Ecología y Etnobiología, EcoCiencia, Quito, Ecuador, p. 376-381.

Araujo, J.E. da S. e Lucas, V. 1930 Catálogo de extractos fluidos dos Laboratórios Silva Araujo, Rio de Janeiro. Silva Araujo \& Cia Ltda 185: +XXIX.

Bennet, B., Alarcón, R. and Cerón, C. 1992 The ethnobotany of Carludovica palmata (Ruiz \& Pavón) (Cyclanthaceae) in Amazonian Ecuador. Economic Botany 46: 233-240. 
Bernardi, H.H. e Wasicky, M. 1959 Algumas pesquisas sobre a "Espinheira Santa" ou "Cancerosa" Maytenus ilicifolia, Martius, usada como remédio popular no Rio Grande do Sul. Universidade Federal do Rio Grande do Sul, Santa Maria, Brasil. 46p.

Buchet, M. 1990 Panama - A legendary hat. Ediciones Libri Mundi. Quito, Ecuador.

Caballero, J. 1991 Use and management of Sabal palms among the Maya of Yucatán: A case of technological innovation based on the folk biological knowledge. En: Rhoades, R.E., Sandoval, V.N. and Bagalanon, C.P. (eds.) Best Paper Awards 1990. Manila Philippines International Potato Center and User's Perspective with Agricultural Research and Development (UPWARD), P. 13-23.

Caballero, J., Pulido, M.T. y Martínez-Ballesté, A. El uso de la palma de guano (Sabal spp.) en la industria turística de Quintana Roo, México. En: Alexiades, M.N. y Shanley, P. (eds.) 2004 Productos forestales, medios de subsistencia y conservación: Estudios de caso sobre sistemas de manejo de productos forestales no maderables. Volumen 3 - América Latina. Centro para la Investigación Forestal Internacional (CIFOR), Bogor, Indonesia.

Carrillo Trueba, C. 2002 Las plantas en la vida de los pueblos de la Chinantla Baja. Tesis profesional. Universidad Nacional Autónoma de México (UNAM), México.

Challenger, A. 1998 Utilización y conservación de los ecosistemas terrestres de México. Pasado, presente y futuro. Comisión Nacional para la Biodiversidad (CONABIO), Universidad Nacional Autónoma de México (UNAM), Agrupación Sierra Madre, México.

Domínguez, M. 1991 El sombrero de paja toquilla. Historia y Economía, Banco Central del Ecuador.

Eccardi, F., Carrillo Trueba, C., Musalem, N. y Ramos, C. 2001 La palma camedora en México. Estudio elaborado para la Comisión para la Cooperación Ambiental del Tratado de Libre Comercio de Norteamérica. Enero-junio de 2001 (manuscrito).

Edouard, F. y Tickin, T. 2001 Hacia un manejo sostenible de la pita o ixtle (Aechmea magdalenae), Colección Manejo Campesino de Recursos Naturales de la red RAISES. 94P.

Herrera, N.D. 1994 Los huertos familiares Mayas en el Oriente de Yucatán. Etnoflora Yucatanense, No. 9. Universidad Autónoma de Yucatán, Mérida.

Hodel, D.R. 1992 Chamaedorea Palms. The International Palm Society/Allen Press, Lawrence, Kansas.

Marquesini, N.R. 1995 Plantas usadas como medicinais pelos índios do Paraná e Santa Catarina, sul do Brasil. Tese, Universidade Federal do Paraná, Curitiba. 
Martinez-Crovetto, R. 1981 Las plantas utilizadas en medicina popular en el noroeste de Corrientes (República Argentina). Tucuman, Ministerio de Cultura y Educación/Fundación Miguel Lillo. Miscelanea No. 69.

Oyama, K. 1984 Biología comparativa entre individuos masculinos y femeninos de Chamaedorea tepejilote (Palmae). Tesis profesional. Facultad de Ciencias, Universidad Nacional Autónoma de México (UNAM), México.

Oyama, K. 1990 Variation in growth and reproduction in the neotropical dioecius palm Chamaedorea tepejilote. Journal of Ecology 78: 648-663.

Oyama, K. and Mendoza, A. 1990 Effects of defoliation on growth, reproduction and survival of a neotropical dioecius palm, Chamaedorea tepejilote. Biotropica 22(2): 119-123.

Sanjuán, R., Gonzalez, J.M. y Huerta, M. 2000 Fuente y arte del piteado Oaxaca, Jalisco. Gobierno del Estado de Jalisco/Secretaría de Promoción Económica, México. 227p.

Santos, E.J. 1996 La pita o Ixtle, Aechmea magdalenae (André) André ex Baker, en las selvas de la Chinantla, Oaxaca. Inédito, México. 15P.

Scheffer, M.C. 2004 Produsão de espinheira-santa (Maytenus ilicifolia Mart. ex Reiss) na região metropolitana de Curitiba, Paraná, Brasil. En: Alexiades, M.N. y Shanley, P. (eds.) 2004 Productos forestales, medios de subsistencia y conservación: Estudios de caso sobre sistemas de manejo de productos forestales no maderables. Volumen 3 - América Latina. Centro para la Investigación Forestal Internacional (CIFOR), Bogor, Indonesia.

Schultes, R.E. 1941 Plantae Mexicanae IX: Aechmea magdalenae and its utilization as a fiber plant. Botanical Museum leaflets 9(7): 117-122.

Steenbock, W. 2000 Medicinal plants: Popular knowledge survey, alternative therapeutics, option of income and environmental conservation in the centre of Paraná State, Brazil. Revista da Sociedade de Olericultura do Brasil 13 (Suplemento): 137-140.

Steenbock, W. 2004 Em busca do manejo sustentável da carqueja (Baccharis trimera Lers) na região central do Paraná, sul do Brasil. En: Alexiades, M.N. y Shanley, P. (eds.) Productos forestales, medios de subsistencia y conservación: Estudios de caso sobre sistemas de manejo de productos forestales no maderables. Volumen 3 - América Latina. Centro para la Investigación Forestal Internacional (CIFOR), Bogor, Indonesia.

Stellfeld, C. 1934 A espinheira-santa: Contribuição ao estudo farmacognóstico. Boletim da Associação Brasileira de Pharmacia 15: 551-571. 
Tickin, T. 1999 Etnoecology de Aechmea magdalenae. Tesis de Doctorado. Universidad McGill de Montreal, Canada.

Tickin, T. and Johns, T. 2002 Chinanteco Management of Aechmea magdalenae: Implications for the Use of TEK and TRM in Management Plants. Economic Botany 56(2):177-191.

Toledo, V.M., Carabias, J., Mapes, C. y Toledo, C. 1985 Ecología y autosuficiencia alimentaria. Siglo XXI editores, México.

Zona, S. 1990 A monograph of Sabal (Arecaceae: Coryphoideae). Aliso 12(4): 583-666.

\section{Seeds/Roots/Shoots}

Atal, C.K. and Kapur, B.M. (eds.) 1982 Cultivation and utilization of medicinal plants. Regional Research Laboratory, Jammu-Tawi-India.

Barros Henriques, R.P. and Elias Girnos de Sousa, E.C. 1989 Population structure, dispersion and microhabitat regeneration of Carapa guianensis in northeastern Brazil. Biotropica 21(3): 204-209.

Brown, H.A., Minott, D.A., Ingram, C.W. and Williams, L.A.D. 1998 Biological activities of the extracts and constituents of Pimiento, Pimenta dioica L. against the southern cattle tick, Boophilus microplus. Insect Science and its Application 18: 9-16.

Clay, J.W., Sampaio, P. de T.B. e Clement, C.R. 1999 Biodiversidade Amazônia: Exemplos e estratégias de utilização. Instituto Nacional de Pesquisas da Amazonia (INPA) e Serviço Brasileiro de Apoio a Micro e Pequenà Empresa (SEBRAE). Manaus, Brasil. 409p.

Corrêa Júnior, C. e Ming, L.C. 2004 Fáfia (Pfaffia glomerata (Spreng.) Pedersen): O ginseng Brasileiro. En: Alexiades, M.N. y Shanley, P. (eds.) 2004 Productos forestales, medios de subsistencia y conservación: Estudios de caso sobre sistemas de manejo de productos forestales no maderables. Volumen 3 - América Latina. Centro para la Investigación Forestal Internacional (CIFOR), Bogor, Indonesia.

Fantini, A.C. 1999 Palm heart (Euterpe edulis) production and management in the Brazilian Mata Atlântica. Tese de Doutorado, University of Wisconsin, USA. 127P. 
Fantini, A.C., Guries, R.P. e Ribeiro, R.J. 2004 Palmito (Euterpe edulis Martius) na Mata Atlântica Brasileira: Um recurso em declínio. En: Alexiades, M.N. y Shanley, P. (eds.) 2004 Productos forestales, medios de subsistencia y conservación: Estudios de caso sobre sistemas de manejo de productos forestales no maderables. Volumen 3 - América Latina. Centro para la Investigación Forestal Internacional (CIFOR), Bogor, Indonesia.

FAO (Food and Agriculture Organization of the United Nations) 1990-2001 FAO Statistical Databases - Agriculture. (www.apps.fao.org/page/collections/subset=agriculture)

Higbee, E.C. and Kelly, J.W. 1950 Possibilities of improving ipecac root by selection. American Journal of Pharmacology 122: 184-188.

Macia, M.J. 1998 La pimienta de Jamaica (Pimenta dioica (L.) Merril, Myrtaceae) en la Sierra Norte de Puebla (México). Anales del Real Jardín Botánico, Madrid 56: 337-349.

Magalhães, P.M. 2000 Agrotecnología para el cultivo de fáfia o ginseng Brasileiro. En: Fundamentos de agrotecnología de cultivo de plantas medicinales Iberoamericanas. Ciencia y Tecnología para el Desarrollo (CYTED), Bogotá, Colombia.

Martínez, M.A, Evangelista, V., Mendoza, M.C., Basurto, F. y Mapes, C. 2004 Estudio de la pimienta gorda, Pimenta dioica (L.) Merrill, un producto forestal no maderable de la Sierra Norte de Puebla, México. En: Alexiades, M.N. y Shanley, P. (eds.) 2004 Productos forestales, medios de subsistencia y conservación: Estudios de caso sobre sistemas de manejo de productos forestales no maderables. Volumen 3 - América Latina. Centro para la Investigación Forestal Internacional (CIFOR), Bogor, Indonesia.

Martínez, M.A., Evangelista, V., Mendoza, M.C., Morales, G., Toledo, G. y Wong, A. 2001 Catálogo de plantas útiles de la Sierra Norte de Puebla, México. Cuadernos 27. Instituto de Biología, Universidad Nacional Autónoma de México (UNAM), México.

Merril, E.D. 1947 The technical name of allspice. Contributions from the Gray Herbarium of Harvard University CLXV: $30-38$

Ming, L.C. e Corrêa Júnior, C. 2001 Collection of fáfia (Pfaffia glomerata (Spreng.) Pedersen) in the northwest region of Paraná State, Brazil. World Conference on Medicinal and Aromatic Plants. Budapest, Hungary. 242p.

Montanari Jr., I., Magalhães, P.M. e Queiroga, C.L. 1997 Influences of plantation density and cultivation cycle in root productivity and tenors of becdysone in Pfaffia glomerata (Spreng.) Pedersen. In: Proceedings of the II World Congress on Medicinal and Aromatic Plants for Human Welfare. International Council for Medicinal and Aromatic Plants (ICMAP), International Society for Horticultural Science (ISHS), Sociedad Argentina Para la Investigación de Productos Aromáticos (SAIPA). Mendoza, Argentina, p. 10-15. 
Ocampo, R.A.S. 2000 Agrotecnología para el cultivo de ipecacuana o raicilla. En: Fundamentos de Agrotecnología de cultivo de plantas medicinales Iberoamericanas. Santa Fe de Bogotá D.C., Colombia: Convenio Andrés Bello y Ciencia y Tecnología para el Desarrollo (CYTED).

Ocampo, R.A.S. 2004 Ipecacuana, Psychotria ipecacuanha (Brotero) Stokes: Un producto no maderable cultivado bajo el bosque en Huetar Norte, Costa Rica. En: Alexiades, M.N. y Shanley, P. (eds.) 2004 Productos forestales, medios de subsistencia y conservación: Estudios de caso sobre sistemas de manejo de productos forestales no maderables. Volumen 3 - América Latina. Centro para la Investigación Forestal Internacional (CIFOR), Bogor, Indonesia.

Palma, T. e Hidalgo, N. 1994 Biotecnología elemento importante en la domesticación de plantas medicinales. En: Domesticación de plantas medicinales en Centroamérica. Centro Agronómico Tropical de Investigación y Enseñanza (CATIE). Serie Técnica, Informe Técnico No. 245. Turrialba, Costa Rica, p. 17.

Purseglove, J.W. 1974 Tropical Crops. Dicotyledons. Longman, London, UK.

Reis, A. 1995 Dispersão de sementes de Euterpe edulis Martius - (Palmae) em uma floresta ombrófila densa montana da encosta Atlântica em Blumenau, SC. Tese de Doutorado, Universidade Estadual de Campinas, Brasil. 154p.

Reis, M.S. 1996 Distribuição e dinâmica da variabilidade genética em populaşões de palmiteiro (Euterpe edulis Martius). Tese de Doutorado, Escola Superior de Agricultura Luiz de Queiroz, Piracicaba, Brasil. 210p.

Reis, M.S. e Reis, A. (eds.) 2000 Euterpe edulis Martius (Palmiteiro) biologia, conservação e manejo. Herbário Barbosa Rodrigues, Itajaí. 335p.

Shanley, P. and Luz, L. 2003 The impacts of forest degradation on medicinal plant use and implications for health care in eastern Amazonia. Bioscience Vol. 53(6): 573-584.

Teran, E. 1990 Plantas de interesse em cosmetologia. Cosmetics and Toiletries 2(5): 18-23.

\section{Bark/Wood}

Arce, J. 1996 Manejo de bosques para producción sostenible de uña de gato: la experiencia del valle del Palcazú. Presentación en el curso: Identificación, producción, propagación y manejo de uña de gato. Universidad Nacional Agraria La Molina. 13-15 Noviembre 1996, Lima. 
Chibnik, M. 2003 Crafting tradition. The making and marketing of Oaxacan wood carvings. University of Texas Press, Austin, USA. 266p.

de Jong, W., Melnyk, M., Alfaro Lozano, L., Rosales, M. and García, M. 1998 Uña de gato: Fate and future of a Peruvian forest resource. Center for International Forestry Research (CIFOR) Occasional Paper No. 18. Bogor, Indonesia.

de Jong, W., Melnyk, M., Alfaro, L., Rosales, M. and García, M. 2000 A concerted approach to uña de gato development in Peru. International Tree Crop Journal 10(4): 321-337.

Lenz, H. 1973 El papel indígena Mexicano. Serie Cultura Sep Setentas No. 65. Editorial Cultura Sep Setentas, México. 186p.

López, C. 1992 El papel amate. Sagrado, profanado y proscrito Ciencias (28): 31-36. Revista de la Facultad de Ciencias, Universidad Nacional Autónoma de México (UNAM), México.

López, C. 2004 "Amate" papel de corteza Mexicano (Trema micrantha (L.) Blume): Nuevas estrategias de cosecha para enfrentar las demandas de mercado. En: Alexiades, M.N. y Shanley, P. (eds.) 2004 Productos forestales, medios de subsistencia y conservación: Estudios de caso sobre sistemas de manejo de productos forestales no maderables. Volumen 3 - América Latina. Centro para la Investigación Forestal Internacional (CIFOR), Bogor, Indonesia.

Moguel, P. and Toledo, V.M. 1999 Biodiversity conservation in traditional coffee systems of Mexico. Conservation Biology 13(1): 11-21.

Nalvarte, W. y de Jong, W. 2004 Uña de gato (Uncaria tomentosa (Willd. Ex Roem. \& Schult) DC. y Uncaria guianensis (Aubl.) Gmel.): Potencial y esperanzas de un bejuco Amazónico del Perú. En: Alexiades, M.N. y Shanley, P. (eds.) 2004 Productos forestales, medios de subsistencia y conservación: Estudios de caso sobre sistemas de manejo de productos forestales no maderables. Volumen 3 - América Latina. Centro para la Investigación Forestal Internacional (CIFOR), Bogor, Indonesia.

Peters, C. M., Purata, S.E., Chibnik, M., Brosi, B.J., López, A.M. and Ambrosio, M. 2003 The life and time of Bursera glabrifolia (H.B.K.) Engl. in Mexico: A parable for ethnobotany. Economic Botany 57(4) 431-441.

Peters, C.M., Rosenthal, J. and Urbina, T. 1987 Otomi bark paper in Mexico: Commercializaton of a pre-Hispanic technology. Economic Botany 41(3): 424-432.

Peters, C.M., Purata, S.E., Chibnik, M., López, A.M., Brosi, B.J. and Ambrosio, M. 2003 The life and times of Bursera glabrifolia (H.B.K.) Engl. in Mexico: A parable for ethnobotany. Economic Botany 57(4): 431-441. 
Purata, S.E., Chibnik, M., Brosi, B., y López, A.M. 2004 Figuras de madera de Bursera glabrifolia H.B.K. (Engl.) en Oaxaca, México. En: Alexiades, M.N. y Shanley, P. (eds.) 2004 Productos forestales, medios de subsistencia y conservación: Estudios de caso sobre sistemas de manejo de productos forestales no maderables. Volumen 3 - América Latina. Centro para la Investigación Forestal Internacional (CIFOR), Bogor, Indonesia.

Purata, S.E., Peters, C.M., Ambrosio, M., Brosi, B.J. y López, A.M. 2004 Los alebrijes de Oaxaca y el manejo de las selvas secas. Ciencia y Desarrollo 30(174): 52-60.

Vázquez-Yanes, C. 1998 Trema micrantha (L.) Blume (Ulmaceae): A promising neotropical tree for site amelioration of deforested land. Agroforestry Systems 40: 97-104.

Zavala Carillo, C.A. y Zevallos Pollito, P. 1996 Taxonomía, distribución geográfica y status del género Uncaria en el Perú: Uña de gato. Universidad Nacional Agraria La Molina, Facultad de Ciencias Forestales, Lima, Perú.

\section{Exudates}

Altamirano, F. 1904 Datos para el estudio del árbol de Lináloe y su esencia. Anales del Instituto Medio Nacional México 6: 69.

Betancourt, Y. 1980 Investigaciones fundamentales para la determinación de las tecnologías de resinación de Pinus caribaea var. caribaea. Tesis en opción al grado de Doctor en Ciencias Forestales. Dresden, Alemania. 220p.

Betancourt, Y. y Villalba, M.J. 2000 El uso de los estimulantes como la vía más inmediata para incrementar los rendimientos de resina en los pinos Cubanos. I SIMFOR. Universidad de Pinar del Río.

Betancourt, Y., Bustamante, J.F., Villalba Fonte, M.J. y Nuñez, S.G. 2004 Aprovechamiento de la resina en Pinus caribaea Morelet var. caribaea Barrett y Golfari. En: Alexiades, M.N. y Shanley, P. (eds.) 2004 Productos forestales, medios de subsistencia y conservación: Estudios de caso sobre sistemas de manejo de productos forestales no maderables. Volumen 3 - América Latina. Centro para la Investigación Forestal Internacional (CIFOR), Bogor, Indonesia.

Bustamante, J.F. 1999 Procesamiento de la resina de Pinus caribaea, var. caribaea y sus componentes para la obtención de productos resinosos. Tesis al Grado Científico de Dr. en Ciencias Forestales, Universidad de Pinar del Río, Cuba. 180p. 
de Andrade, A.G. 1998 Um novo produto florestal não-madeireiro: O "couro vegetal". Estudo de uma situação extrativista. Relatório de pesquisa Fundação de Amparo à Pesquisa do Estado de São Paulo (FAPESP), São Paulo, Brasil.

Emperaire, L. 1997 L'exploitation des héveas dans la Réserve Extractiviste du Haut Juruá (Acre, Amazonie Brésilienne). In: Journal d'Agriculture Traditionnel et de Botanique Applique (JATBA), Revue d'Ethnobiologie 39: 109-132.

Emperaire, L. e de Almeida, M.B. 2002 "Seringueiros e seringas". In: Carneiro da Cunha, M. e de Almeida, M.B. Enciclopédia da Floresta. Alto Juruá: Conhecimentos e práticas das populações. São Paulo, Companhia da Letras, p. 285-309.

Hersch-Martínez, P., Glass, R. y Fierro, A.A. 2004 El linaloe (Bursera aloexylon (Schiede) Engl.): Una madera aromática entre la tradición y la presión económica. En: Alexiades, M.N. y Shanley, P. (eds.) 2004 Productos forestales, medios de subsistencia y conservación: Estudios de caso sobre sistemas de manejo de productos forestales no maderables. Volumen 3 - América Latina. Centro para la Investigación Forestal Internacional (CIFOR), Bogor, Indonesia.

Medina, I. 1997 Maque prehispánico: Una antigua discusión. En: Lechuga, R. et al. (eds.) Lacas Mexicanas. Museo Franz Mayer y Artes de México, p. 21-27.

Pantoja, M.C. 2004 Couro vegetal: O látex (Hevea brasiliensis Müll. Arg.) na moda. En: Alexiades, M.N. y Shanley, P. (eds.) 2004 Productos forestales, medios de subsistencia y conservación: Estudios de caso sobre sistemas de manejo de productos forestales no maderables. Volumen 3 - América Latina. Centro para la Investigación Forestal Internacional (CIFOR), Bogor, Indonesia.

Rzedowski, J. 1998 Diversidad y orígenes de la flora fanerogámica en Mexico. En: Diversidad biológica de México. Orígenes y distribución. Ramamoorthy, T.P. et al. (eds.) Universidad Nacional Autónoma de México (UNAM), México.

Samek, V. y Del Risco, E. 1989 Los pinares de la provincia de Pinar del Río, Cuba. Estudio Sinecológico, Editorial Academia, La Habana.

Silberling, L., Pantoja, M.C. e Anderson, A. 2002 Couro vegetal: Desenvolvimento de um produto artesanal para o Mercado. In: Anderson, A. e Clay, J. 2002 Esverdeando a Amazônia: Comunidades e empresas em busca de práticas para negócios sustentáveis. Peirópolis, São Paulo, p. 105-119.

Toledo Manzur, C.A. 1982 El género Bursera (Burseraceae) en el Estado de Guerrero (México). Facultad de Ciencias, Universidad Nacional Autónoma de México (UNAM), México. 


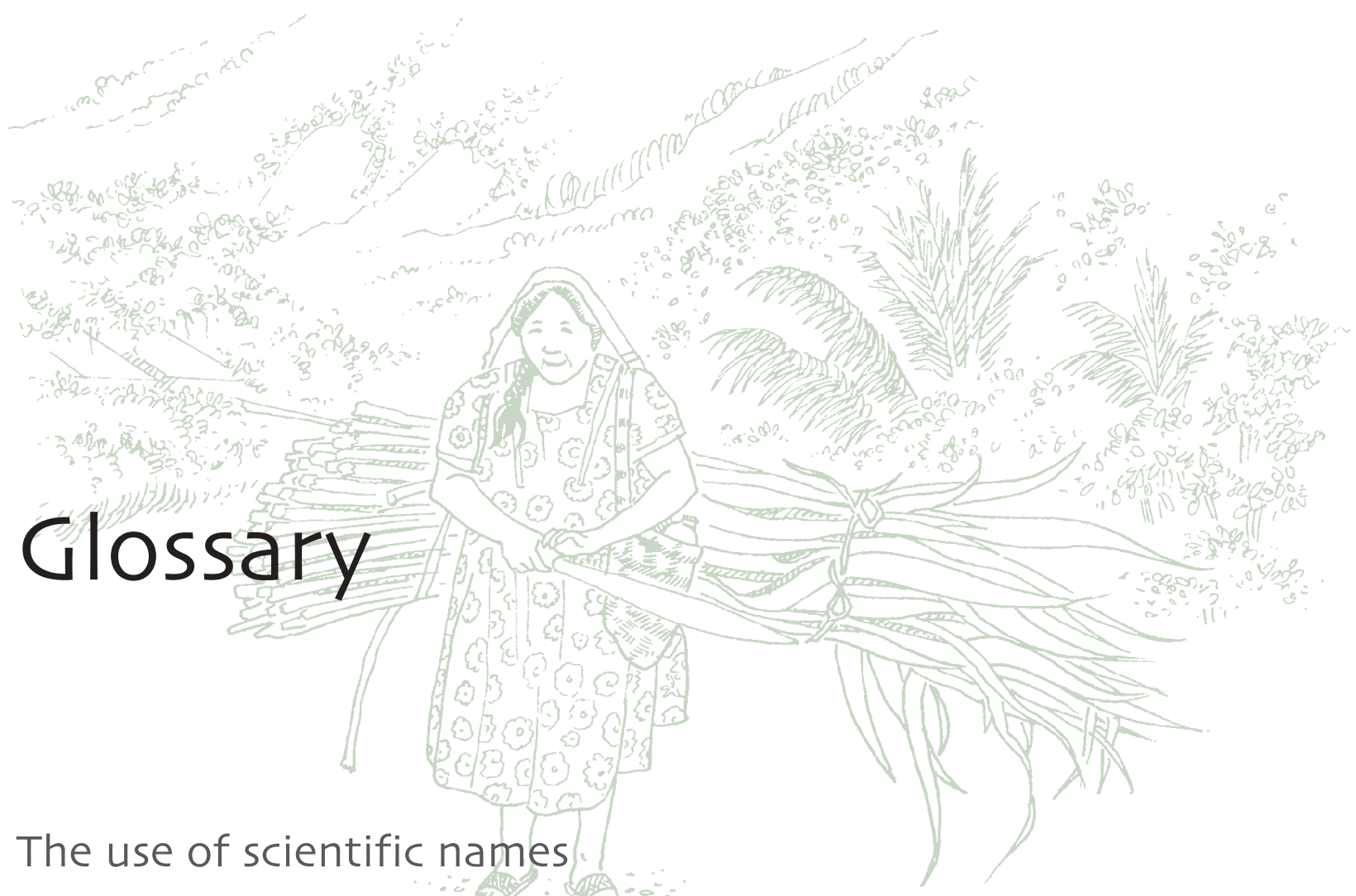

At the start of each case in this volume you will have noticed the scientific names of the different forest plants (and animals) that are profiled. Biological classification helps us to understand the natural world and structure our knowledge. It enables people to identify and record species, providing a universal language of communication and serving as an important tool in nature conservation.

Each different species has a scientific name, which is a Latin binomial (or two-part name). This consists of a genus, followed by a species name and the name or initials of the person (or people) that published the first scientific description of that species (e.g. Ruiz \& Pavón). When it comes to naming plants, the system of 'botanical nomenclature' is used to distinguish and identify different types of plants. There are a number of reasons for this:

\section{Universal Recognition}

A plant can be identified in any country around the world using its botanical name - overcoming the barrier of different languages. 


\section{Relationships}

Plant relationships can easily be determined by examining the botanical classification.

\section{Identification}

Common names are problematic and vary between districts. For instance, the name 'fáfia' could refer to any of the 70 or so species of Pfaffia.

\section{Origins}

The origins of the plant can be established by looking at the name. For example, indicating if it is a hybrid (i.e. the offspring of two different plant species or varieties).

\section{Genus}

Genus names are always written in italics and begin with a capital letter (e.g. Bursera). They may be derived from the name of a famous botanist or from classical Latin names relating to the relevant plant. Bursera for example is named after J. Burser, a seventeenth century botanist. Alternatively, they may be Latinised forms of more common names, drawing on languages like French or English.

\section{Species}

This level consists of a general epithet or genus name and a specific epithet or species name (e.g. Orbignya phalerata). The species name distinguishes exactly which plant is being referred to within a given genus. Species names are always written in italics, using lower case letters, and are usually descriptive. For example, they may provide clues to a plant's origins (e.g. Pinus caribaea $=$ from the Caribbean and Hevea brasiliensis = from Brazil). They may describe the plant or animal (e.g. The name Uncaria tomentosa was coined in 1830 from the Latin "uncus" = claw and "tomentosa" = fine hair). Or they may signify that a particular plant or animal is named after someone (if the species name has the suffix -i or -ii. e.g. Cassipourea flanaganii is named after Henry George Flanagan, a nineteenth century South African plant collector).

\section{Subspecies}

Sometimes within a species there is significant variation but not enough to assign another species. In this instance, the classification 'subspecies' is used. Subspecies names are always written in italics, using lower case letters, and like species names, are often descriptive (e.g. Hevea guianensis subsp. marginata or Hevea guianensis subsp. occidentalis). 


\section{Varietas (Variety)}

Sometimes within a species (or subspecies) there is moderate variation, requiring the more subtle classification of 'varietas' or 'variety'. Varietas names are always written entirely in lower case italics and again, are often descriptive (e.g. Pinus caribaea var. caribaea, Pinus caribaea var. hondurensis or Pinus caribaea var. bahamensis).

Acahuales - A term used in tropical areas of Mexico, referring to land formerly used for agriculture which is in the process of converting back into forest vegetation.

Agrochemicals - Agricultural chemicals, including fertilisers, pesticides, etc.

Agroforestry - Diverse farming systems whereby trees are integrated with crops to increase production and also, social and environmental benefits.

Alkaloids - A class of basic nitrogenous organic compounds occurring in plants (such as nicotine or morphine).

Analogues - Materials which can be used as substitutes for other materials, due to their similar structure or appearance. For example, in the Brazilian fáfia case, with a similar appearance and properties to Asiatic ginseng, fáfia (Pfaffia glomerata) is used as a substitute for that popular herbal remedy.

Anti-Coagulant - A substance that reduces or prevents the coagulation of fluids like blood or latex (i.e. it reduces the transformation of such fluids into a thickened mass).

Anti-Inflammatory - A medicine or substance with properties that help to reduce the inflammation and swelling associated with certain illnesses.

Apical - A region at the tip of each plant shoot and root in which cell divisions are continually occurring to produce new stem and root tissue respectively.

Araucaria Forests - Forests dominated by coniferous trees belonging to the genus Araucaria. These forests originate in the Southern Hemisphere and include species like the hoop pine.

Astringent - A substance that has refreshing, tightening or drying properties when applied to the skin. Medicinally, the term relates to a substance that has contracting and constricting properties, or in terms of taste, an unpleasant, dry taste (for example, as in wines, due to the presence of tannin).

Artificial Pollination - The process whereby pollen is introduced manually to fertilise the flowers of particular plants, facilitating plant breeding or fruit production. (See also 'pollination')

Biodiversity - Biological diversity. The variety of life in all its forms, levels and combinations including ecosystem diversity, species diversity, and genetic diversity. 
Caboclos - In the Brazilian Amazon this term refers to people of mixed Indian and Anglo-Saxon descent. Millions of Brazilians have some kind of native Indian ancestry, usually on the side of their grandmothers or great-grandmothers, and this is especially true of the Amazon region.

Calcium Oxalate Crystals - Long, thin, calcium-rich microscopic crystals (raphides) found in plant tissues. These are very common in spinach, aroids and palms.

Canopy - The upper layer of tree crown in a forest, providing a cover of filtered light for understorey trees and plants.

Certification - The process of official authorisation. For example, in terms of producing forest goods, this could involve verifying that the goods are produced organically (without the use of chemicals) or that they are harvested in a sustainable manner, meeting certain predetermined standards and requirements.

Coniferous - Evergreen, cone bearing trees (such as pine, fir, spruce or larch trees), known as 'conifers'.

Conquistadores - This term refers to Spanish conquerors or adventurers, especially in the context of their exploration of Mexico, Peru or Central America in the sixteenth century.

Cross Breed - The reproduction of offspring as a result of breeding between two genetically distinct parents. In terms of plant breeding, the two parent plants differ in the traits that they exhibit. For example, a wild and a domesticated variety may be combined in an attempt to improve the qualities of the plant's fruit or bark, etc.

Cross-Fertilisation - The process of fertilisation, where pollen from another plant (of the same species) is required to fertilise a flower. This contrasts with 'self-fertilisation', where both the egg and pollen are from the same flower or plant.

Crown - The uppermost layer of foliage on a tree or in a forest, through which filtered light reaches the understorey trees and plants below.

Cultivar - A variety of plant that has been produced only under cultivation.

Cuttings - Small sections of a plant, usually taken from the stem, for propagation. That is, they are grown in a solution or soil until new shoots and roots appear. Once established, such cuttings can be transplanted.

Decoction - A preparation obtained by boiling a substance (like a herb) in water, to extract its active ingredients.

Diuretic - A medicine or substance that increases the volume of urine produced.

Domesticate/Domesticating - The process by which formerly wild plants or animals are retained or integrated into farmland systems or home gardens, sometimes involving selective breeding over many generations to improve desirable characteristics for human benefit. 
Ecology - The study of the interactions of organisms with their physical environment and with one another.

Ecosystem - A community of living organisms interacting with each other and the physical environment in which they live.

Ejidatario - A member of an ejido (see next entry), that is, an individual who has a beneficiary interest in the communal ejido land.

Ejido - An area of farmland held in communal ownership but divided into separate family plots. Ejidos emerged as a uniquely Mexican form of redistributing large landholdings at the start of the nineteenth century.

Endocarp - The wall of the fruit that encloses the seeds. In some fruits, like $u x i$, it becomes hard and "stony".

Estuary - The mouth or lower course of a river, where the river's current meets the sea's tides and is subject to their effects.

Enzyme - Any protein capable of facilitating a chemical reaction that is necessary for the host cell or organism.

Evergreen - Trees and shrubs that retain living leaves throughout the year. The leaves of the past season are not shed until the new foliage has been completely formed. This contrasts with 'deciduous' plants, which lose their leaves during a certain season.

Fallow - Formerly planted land that is left uncultivated or unseeded for one or more seasons. The fields may be ploughed and then left to rest.

Field Trials - Studies carried out in the field which are designed to test whether a particular hypothesis is valid, or whether the results of laboratory research will be effective in the field.

Flavonoids - Plant pigments. These are the most important pigments involved in floral colouration and probably occur in all flowering plants.

Flood Plains - Fairly flat land that can be found on one or both sides of a stream or river, and which is subject to overflow flooding when water levels are high.

Foliage - The leaves of a plant collectively.

Fronds - Finely divided leaves, which are often large; associated with ferns and some palms.

Gallery Forest - Forest vegetation consisting of trees and shrubs growing alongside or close to a watercourse (e.g. a lake, swamp or river). In some cases the root systems reach the underground water level. Also known as 'riparian forest'.

Genetic - Relating to the genetic code: the arrangement of chromosomes, genes and deoxyribonucleic acid (or DNA) found within living cells. This code carries the hereditary material of living organisms and is passed on from parents to offspring. 
Genetically Identical - Organisms that share the same genetic code (e.g. plants that arise from the shoots of parent plants).

Genetic Diversity - The diversity of biological life, due to the different make up of the genetic code in different species and in different individuals of the same species.

Genus - In biological classification, the genus represents the usual form of subdivision within a family or subfamily. It often contains more than one species, essentially very similar to each other and regarded as closely related. The genus designation is the first part of a scientific name (e.g. Endopleura uchi, the uxi tree).

Germinate - To sprout, bud or begin to grow from seed.

Grasslands - An area in which the natural vegetation consists largely of perennial grasses, with trees that are either limited to stream valleys or are widely scattered; characteristic of sub-humid and semi-arid climates.

Gringos - A fairly derogatory term used in Latin America to refer to white, English-speaking people, usually from the United States, and especially in the context of alleged economic, cultural and political interference in Latin America.

Gourd - The fruit of any of the various 'cucurbitaceous' or similar plants. This term especially relates to the bottle gourd and certain squashes, the dried shells of which are used for making ornaments, drinking cups, etc.

Habitat - The environment of an organism or species; the place where it is usually found living.

Hardwood - Woody tree species belonging to the 'dicot' class of angiosperms (or flowering plants) characterised by having two seed leaves, net veined leaves and flower parts usually in multiples of fours or fives. Hardwoods often, but not always, have hard wood.

Herbaceous - Non-woody plants; herb-like.

Indigenous - Originating or occurring naturally in a particular region or country, native to an area.

Manioc - Tropical plants of the genus Manihot (from the Family Euphorbiaceae), also known as 'cassava'. Different species are cultivated for their tuberous roots, which yield important food products, including a root vegetable, which can be eaten or turned into a starchy flour.

Mestizo - A person of combined ancestry, with parents or ancestors of different racial origins. This term refers particularly to Latin Americans of both Native American and European ancestry. Mestizos form the largest population group in many Latin American countries.

Milpa - This term, from the indigenous Nahuatl language in Mexico, refers to a piece of land used to cultivate maize and other crops, like tomatoes and beans.

Monoculture - The use of land for growing only one type of crop. 
Mucilage - A gummy secretion or gelatinous substance present in some plants.

Mulch - Organic material (like straw or compost) that is either dug into the soil or placed on top of the soil layer around the base of plants. Mulch serves to protect the plants, conserve moisture, reduce weeds and provide organic nutrients for plant growth.

Native - Originating or occurring naturally in a particular region or country; indigenous to an area.

Old-Growth Forest - Primary forest containing a mature mixture of plant species and wildife in a relatively undisturbed environment.

Organic Matter - Biological material. For example, a rich and fertile layer of organic matter often lines the forest floor, comprised of mainly decomposing leaves and wood, along with other biological matter and micro-organisms.

Organic Products - Goods that are grown and produced using natural methods, without the aid of chemicals (artificial fertilisers, pesticides, etc).

Pectins - Molecules primarily comprised of sugar acids (carbohydrates), which can be found in the cell walls of plants. Normally pectins are present in an insoluble form but in ripening fruits they change into a water-soluble form.

Perennial - A plant in which the life cycle spans more than two years.

Petiole - The stalk that attaches a leaf blade to the stem of a plant.

Photosynthesis - The process whereby plants convert light energy into chemical energy. This occurs in special 'chloroplasts' within the plant cells, where the energy from sunlight is used to convert water and carbon dioxide into carbohydrates.

Pollination - The process whereby pollen from a male flower (or male parts of a bisexual flower) fertilises a female flower (or female parts of a bisexual flower) of the same species. This may occur, in 'self-fertilisation', within the same flower or between different flowers on the same plant, or in 'cross-fertilisation', between different flowers on different plants, depending on the circumstances and species. Pollination can be assisted by agents like the wind, water, birds and animals.

Pollinators - Agents that pollinate flowers (i.e. assist the process of plant fertilisation), including birds, bees and other insects.

Potreros - Portions of land which are covered with pasture/grassland and used for raising cattle.

Primary Forest - Mature, old growth forest.

Pulp - The fleshy, often soft portion of a fruit.

Reforestation - The replanting of forest trees on forest land that has been cleared or harvested.

Rhizome - A thick horizontal stem, usually growing underground, which sends out shoots above ground and roots below. 
Rind - The outer layer of a fruit; the peel or skin.

Secondary Forest - Forest regrowth following significant disturbance of the original vegetation. The new growth often differs in forest structure and species composition compared to primary forest (i.e. mature, old growth forest).

Semi-Natural Forest Systems - Sections of forest which retain elements of their natural state and vegetation but which have been used for cultivating crops that can grow under the forest canopy, or which have been manipulated in other ways.

Shade-Grown Coffee Plantations - Coffee plantations in which the coffee bushes are found growing beneath the shade of trees. The trees help to retain and nourish the soil, and moderate the heat and light reaching the coffee plants. In addition to providing shade, the trees often have other uses for farmers (such as providing harvestable timber, bark or fruits), and they also provide food and shelter for wildlife.

Sheaths - The bases of certain leaves where they form a closely enveloping, protective layer around the stem.

Sinusitis - Inflammation of a sinus or sinuses (i.e. a hollow cavity within a bone or other tissue, especially in relation to the facial bones that connect with the nasal cavities).

Sustainable/Sustainably - The gathering of plants or plant products in a way that does not jeopardise the reproductive capacity or regenerative potential of a particular species within a given area (and which does not have a detrimental impact on the surrounding ecosystem of living organisms and their environment, or the social structure of those who harvest and process plant products).

Sustainable Harvesting - This is achieved by following management or harvesting guidelines which allow for product extraction while at the same time fostering the regeneration of the harvested species in a given area. Measures are put in place to ensure that the extraction of a particular type of plant or animal product does not adversely affect the ability of the remaining stocks to recover.

Sustainable Management - Local management of a given species which involves planning and guidelines to ensure that over-harvesting does not take place, plant products are extracted in a sustainable manner, and regeneration is allowed to occur (or replanting takes place) to cater for future needs.

Tannins - A group of astringent vegetable compounds, found for example, in the bark of certain acacia species (which give the bark tanning properties), or in grape skins, stalks and seeds (which confer a distinctive tannin taste to some wines).

Tiquisque - The local name in Costa Rica for Xanthosoma sagittifolium (L.) Schott, a plant species from the tropical rainforest. This plant has traditionally been used as a subsistence crop, and is widely cultivated in the American tropics. The usable parts include the subterranean tuberous stems (which have high levels of carbohydrates and protein) and the young leaves, which are similar to spinach. 
Transplant Seedlings - Seedlings, tiny new plants arising from seeds, are replanted into sections of land where the growth of the plants can be encouraged and monitored.

Tuberous - Bearing tubers (that is, enlarged, fleshy underground stems such as that of the potato); usually oblong or rounded thickenings or outgrowths.

Understorey - Plants growing under the canopy of taller plants or trees.

Vegetal - Pertaining to (or of the nature of) plants or vegetables.

Wetlands - These transition zones between dry land and bodies of water are permanently or seasonally saturated with fresh, saline or marine water. They vary from shallow, transitory ponds or pools to more permanent marshes, bogs or swamps. 


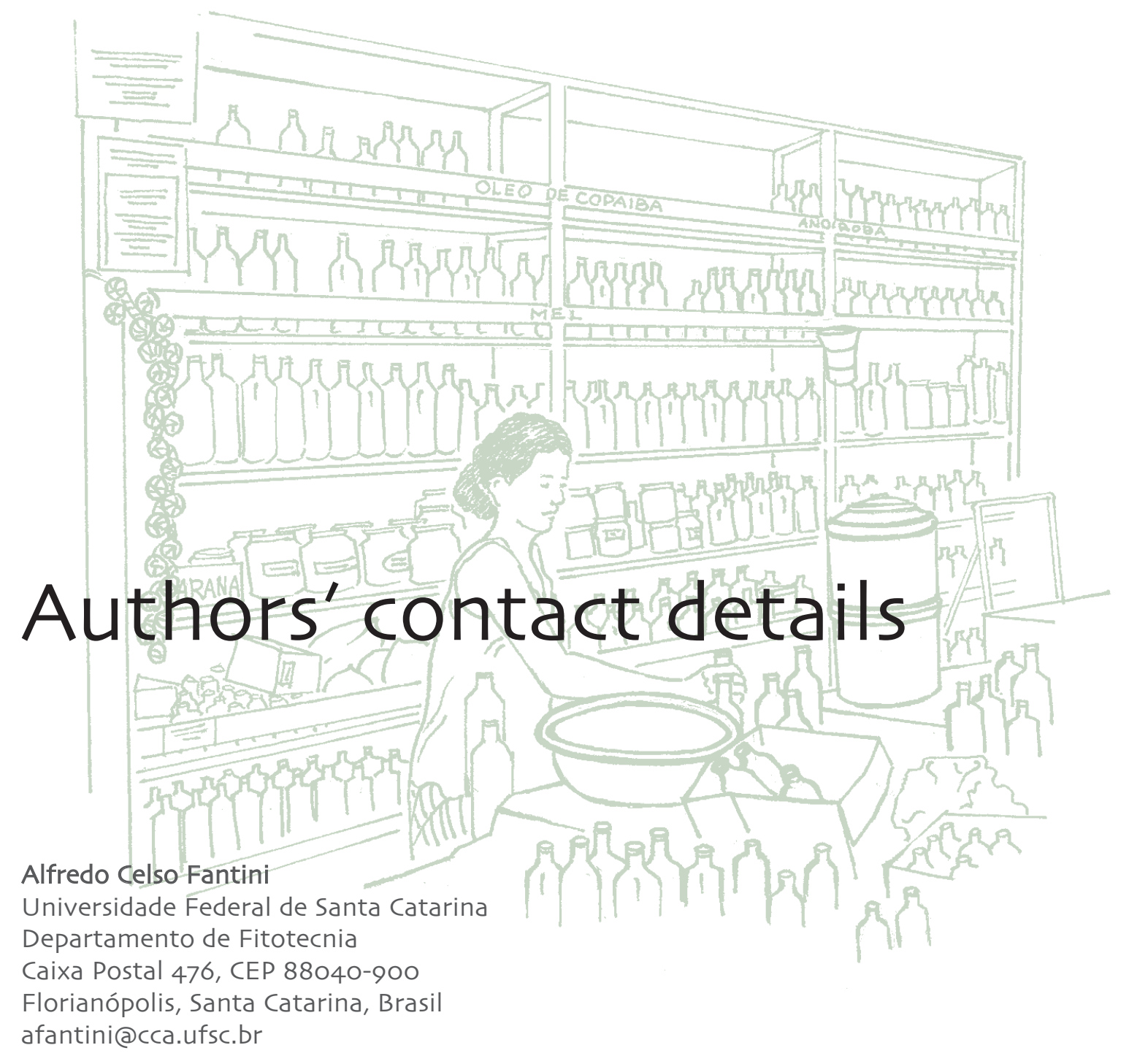

\section{Andrea Martinez-Ballesté}

Jardín Botánico, Instituto de Biología

Universidad Nacional Autónoma de México (UNAM)

Apartado postal 70-614, Coyoacán C.P. 04510

México, D.F. México

aballeste@hotmail.com

\section{Berry J. Brosi}

Institute of Economic Botany

The New York Botanical Garden

Bronx, NY 10458, USA

bbrosi@stanford.edu 


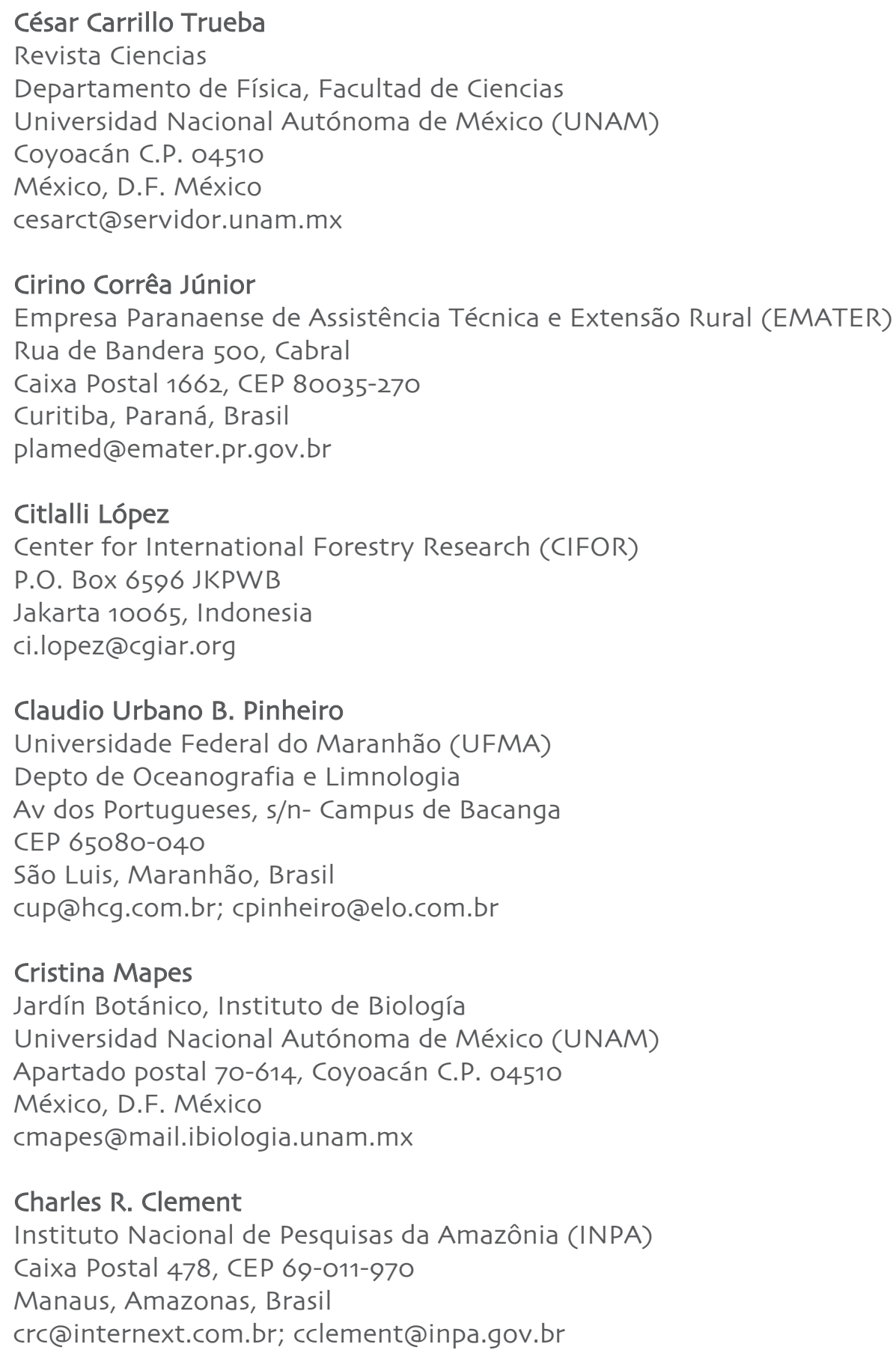




\section{Erik Arancibia \\ Heifer Project Bolivia \\ harancibia@yahoo.com.ar \\ e.arancibia@heifer-bolivia.org}

\section{Fausto López}

Consultor independiente

Ave. 16 de Julio \#1490

Edif. Avenida, Planta Baja, Oficina 9

La Paz, Bolivia

tarakaraja@yahoo.es

\section{Fabrice Edouard}

Methodus Consultoras S.C.

Calle de Crespo 520-A

Col. Centro, C.P. 68000

Oaxaca, Oax, México

fabrice@raises.org

Sitio web: www.raises.org

\section{Francisco Basurto Peña}

Jardín Botánico, Instituto de Biología

Universidad Nacional Autónoma de México (UNAM)

Apartado postal 70-614, Coyoacán C.P. 04510

México, D.F. México

abasurto@mail.ibiologia.unam.mx

\section{Gabriel Medina}

Convênio Empresa Brasileira de Pesquisa Agropecuária (EMBRAPA)/

Center for International Forestry Research (CIFOR)

Embrapa Amazônia Oriental

Trav. Enéas Pinheiro S/N

CEP 66.905-780

Belém, Pará, Brasil

g.medina@cigar.org

\section{Gloria Gaia}

Mulheres da Mata

Instituto do Homem e Meio Ambiente da Amazônia (IMAZON)

Caixa Postal 1015, CEP 66017-000

Belém, Pará, Brasil

imazon.bel@zaz.com.br 


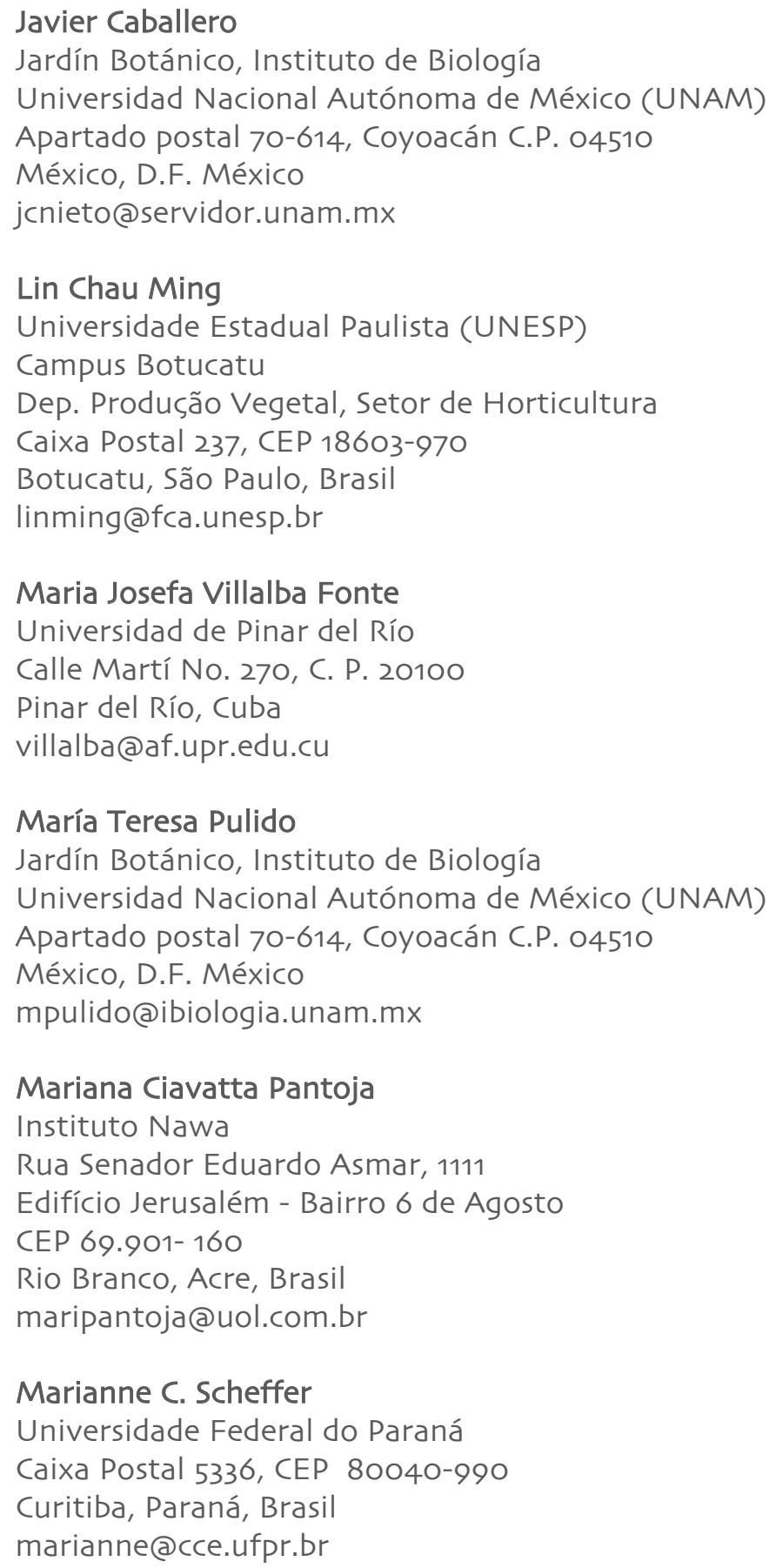




\section{Mario Pinedo Panduro}

Calle Napo 619 Apartado Postal 471

Iquitos, Perú

mariopp@meganet.com.pe

\section{Martin Ricker}

Estación de Biología Tropical "Los Tuxtlas"

Universidad Nacional Autónoma de México (UNAM)

Apartado Postal 94, C.P. 95701

San Andrés Tuxtla, Veracruz, México

mricker@servidor.unam.mx

Michael Chibnik

Department of Anthropology, University of Iowa

114 Macbride Hall

lowa City, IA 52242-1322, USA

michael-chibnik@uiowa.edu

Miguel Angel Martínez Alfaro

Jardín Botánico, Instituto de Biología

Universidad Nacional Autónoma de México (UNAM)

Apartado postal 70-614, Coyoacán C.P. 04510

México, D.F. México

malfaro@mail.ibiologia.unam.mx

\section{Miguel N. Alexiades}

Department of Anthropology, University of Kent

Canterbury $\mathrm{CT}_{2} 7 \mathrm{NS}$, United Kingdom

m.n.alexiades@kent.ac.uk

\section{Myrna Mendoza Cruz}

Jardín Botánico, Instituto de Biología

Universidad Nacional Autónoma de México (UNAM)

Apartado postal 70-614, Coyoacán C.P. 04510

México, D.F. México

myrna@mail.ibiologia.unam.mx

\section{Patricia Shanley}

Center for International Forestry Research (CIFOR)

P.O. Box 6596 JKPWB

Jakarta 10065, Indonesia

p.shanley@cgiar.org 
Paul Hersch-Martínez

Instituto Nacional de Antropología e Historia (INAH)

Matamoros 14, Acapantzingo C.P. 62440

Cuernavaca, Morelos, México

leon@buzon.uaem.mx

Rafael A. Ocampo Sánchez

Jardín Agroecológico Bougainvillea

San José, Costa Rica

quassia@racsa.co.cr

\section{Rocío Alarcón Gallegos}

Corporación de Gestión y Derecho Ambiental Ecuador (ECOLEX)

Brookfield Road, Market Harborough

Leicestershire LE16 9DU, United Kingdom

r.viteri@btopenworld.com

\section{Silvia E. Purata}

Instituto de Ecología, A.C.

km. 2.5 Antigua Carretera a Coatepec

C.P. 91070

Xalapa, Veracruz, México

silvia@ecologia.edu.mx

\section{Socorro Ferreira}

Embrapa Amazônia Oriental

Trav. Enéas Pinheiro S/N

CEP 66.905-780

Belém, Pará, Brasil

socorro@cpatu.embrapa.br

\section{Virginia Evangelista Oliva}

Jardín Botánico, Instituto de Biología

Universidad Nacional Autónoma de México (UNAM)

Apartado postal 70-614, Coyoacán C.P. 04510

México, D.F. México

voliva@mail.ibiologia.unam.mx

\section{Ynocente Betancourt Figueras}

Universidad de Pinar del Río

Calle B. Edif. 13. Apto A-3

Calero. Pinar del Río, Cuba

rolando@geo.upr.edu.cu; rolando@tele.upr.edu.cu;

betancourt@af.upr.edu.cu 


\section{Yolanda Nava-Cruz}

Estación de Biología Tropical "Los Tuxtlas"

Universidad Nacional Autónoma de México (UNAM)

Apartado Postal 94, C.P. 95701

San Andrés Tuxtla, Veracruz, México

ynava@ate.oikos.unam.mx

\section{Walter Nalvarte}

Centro para la Investigación Forestal Internacional (CIFOR)

Oficina Regional en Perú

Carretera Federico Basadre km 4,200

Pucallpa, Perú

wnalvarte@wayna.rcp.net.pe

Walter Steenbock

Fundação para o Desenvolvimento Econômico Rural da Região

Centro-Oeste do Paraná (RURECO)

Rua Jesuino Marcondes 1161

CEP 85100-970

Guarapuava, Paraná, Brasil

rureco@gol.psi.br

\section{Wil de Jong}

Center for International Forestry Research (CIFOR)

P.O. Box 6596 JKPWB

Jakarta 10065, Indonesia

w.dejong@cgiar.org 


\title{
Source material used for the illustrations
}

\author{
Front cover \\ Redrawn from an illustration by Anabelle Maffioli (in ANAI Serie de Boletines Técnicos para el \\ Agricultor, Boletín Técnico No. 3, El Pejibaye, 1986). \\ vi \\ vii \\ ix \\ Page 1 \\ Page 5 \\ Page 7 \\ Page 8 \\ Page 9 \\ Page 10 \\ Page 11 \\ Page 13 \\ Based on a photo by César Carrillo Trueba \\ Based on a photo by César Carrillo Trueba \\ Based on a photo by Gabriel Medina \\ Based on a photo by Gabriel Medina \\ Platonia insignis, drawn from a living sample, Empresa Brasileira de Pesquisa Agropecuária \\ (EMBRAPA), Belém, Brazil \\ Based on a photo by Patricia Shanley \\ Based on a photo by Patricia Shanley \\ Bactris gasipaes, drawn from a living sample, Empresa Brasileira de Pesquisa Agropecuária \\ (EMBRAPA), Belém, Brazil \\ Redrawn from an illustration by Anabelle Maffioli (in ANAI Serie de Boletines Técnicos para el \\ Agricultor, Boletín Técnico No. 3, El Pejibaye, 1986). \\ Redrawn from an illustration by Anabelle Maffioli (in ANAI Serie de Boletines Técnicos para el \\ Agricultor, Boletín Técnico No. 3, El Pejibaye, 1986). \\ Myrciaria dubia, drawn from a living sample, Empresa Brasileira de Pesquisa Agropecuária \\ (EMBRAPA), medicinal plants garden, Belém, Brazil \\ Page 14 \\ Page 17 \\ Page 18 \\ Page 19 \\ Page 20 \\ Page 21 \\ Page 23 \\ Page 24 \\ Page 25 \\ Page 26 \\ Page 27 \\ Page 29 \\ Based on a photo by Mario Pinedo Panduro \\ Orbignya phalerata, drawn from a photo by Harri Lorenzi (in Lorenzi, H. 1996 Palmeiras No Brasil: \\ Nativas e Exotica, Editora Plantarum LTD, Brasil) \\ Based on a photo by Claudio Urbano B. Pinheiro \\ Based on a photo by Claudio Urbano B. Pinheiro \\ Based on a photo by Claudio Urbano B. Pinheiro \\ Pouteria sapota, based on photos (of living samples) by Martin Ricker \\ Based on a photo by Martin Ricker \\ Based on a photo by Martin Ricker \\ Endopleura uchi, drawn from a living sample, Empresa Brasileira de Pesquisa Agropecuária \\ (EMBRAPA), Belém, Brazil \\ Drawn from a sample \\ Top: Based on a photo by Patricia Shanley \\ Maytenus ilicifolia, drawn from a living sample, Empresa Brasileira de Pesquisa Agropecuária \\ (EMBRAPA), medicinal plants garden, Belém, Brazil \\ Page $30 \quad$ Left: Based on a photo by Marianne C. Scheffer
}


Page 30

Page 31

Page 32

Page 33

Page 35

Page 36

Page 37

Page 39

Page 41

Page 42

Page 43

Page 44

Page 45

Page 47

Page 48

Page 49

Page 50

Page 51

Page 52

Page 53

Page 54

Page 55

Page 56

Page 57

Page 60

Page 61

Page 63

Page 64

Page 65

Page 66

Page 67
Right: Redrawn from photos in: Anuário Brasileiro da erva-mate de 1999. É editado pela. O Diretor Editor é Romeu Inácio Neumann. Gazeta Grupo de Comunicasões em Santa Cruz do Sul, Rio Grande do Sul, Brasil (photos by Inor Assmann/Agência Assmann and Silvio Ávila)

Based on a photo by Marianne C. Scheffer

Based on a photo by Marianne C. Scheffer

Chamaedorea elegans, drawn from a living simple, Museu Paraense Emílio Goeldi, Belém, Brazil

Based on a photo by César Carrillo Trueba

Based on a photo by César Carrillo Trueba

Carludovica palmata, drawn from a living simple, Praça de Belém (Plaza),

Brazil

Top: Based on a photo by Rocío Alarcón Gallegos

Bottom: Based on a photo by Rocío Alarcón Gallegos

Carludovica palmata, based on photos (of living samples) by Rocío Alarcón Gallegos

Based on a photo by Elaine Marshall

Based on a photo by Elaine Marshall

Based on a photo by Elaine Marshall

Achmea magdalenae, drawn from a botanical specimen, Instituto de Ecología A.C. Herbarium, Xalapa, Mexico

Top: Based on a photo by Elaine Marshall

Bottom: Based on a photo by Fabrice Edouard

Redrawn from an illustration supplied by case author, Fabrice Edouard

Baccharis trimera, drawn from a botanical specimen, Empresa Brasileira de Pesquisa Agropecuária (EMBRAPA), Herbarium, Belém, Brazil

Based on a photo by Walter Steenbock

Based on a photo by Walter Steenbock

Based on a photo by Walter Steenbock

Sabal yapa, based on photos (of living samples) by Javier Caballero

Based on a photo by Carlos Martorell

Based on a photo by Javier Caballero

Based on a photo by María Teresa Pulido

Pimenta dioica, drawn from a botanical specimen, Instituto de Ecología A.C. Herbarium

Top: Based on a photo by Myrna Mendoza Cruz

Bottom: Based on a photo by Francisco Basurto Peña

Pfaffia glomerata, drawn from a living sample, Empresa Brasileira de Pesquisa Agropecuária (EMBRAPA), medicinal plants garden, Belém, Brazil

Based on a photo by Cirino Corrêa Júnior

Based on a photo by Cirino Corrêa Júnior

Psychotria ipecacuanha, drawn from a living sample, Empresa Brasileira de Pesquisa Agropecuária (EMBRAPA), medicinal plants garden, Belém, Brazil

Based on a photo by Rafael A. Ocampo Sánchez

Based on a photo by Rafael A. Ocampo Sánchez 
Page 69

Page 70

Page 71

Page 72

Page 73

Page 74

Page 75

Page 77

Page 78

Page 79

Page 80

Page 81

Page 85

Page 86

Page 87

Page 88

Page 89

Page 92

Page 93

Page 94

Page 95

Page 96

Page 97

Page 98

Page 99

Page 101

Page 109

Page 122

Page 131

Back cover
Euterpe edulis, drawn from a photo by Harri Lorenzi (in Lorenzi, H. 1996 Palmeiras No Brasil: Nativas e Exotica, Editora Plantarum LTD, Brasil)

Based on sketches by Alfredo Celso Fantini

Based on sketches by Alfredo Celso Fantini

From Left to Right: Based on sketches by Alfredo Celso Fantini

Carapa guianensis, drawn from a living sample, Empresa Brasileira de Pesquisa Agropecuária (EMBRAPA), medicinal plants garden, Belém, Brazil

Based on a photo by Patricia Shanley

Based on a photo by Patricia Shanley

Bursera glabrifolia, drawn from a botanical specimen, Instituto de Ecología A.C. Herbarium, Xalapa, Mexico

Drawn from a sample

Based on a photo by Silvia E. Purata

Based on a photo by Silvia E. Purata

Uncaria tomentosa, drawn from a botanical specimen, Empresa Brasileira de Pesquisa Agropecuária (EMBRAPA), Herbarium, Belém, Brazil

Trema micrantha, drawn from a botanical specimen, Instituto de Ecología A.C. Herbarium, Xalapa, Mexico

Drawn from a sample

Based on a photo by Citlalli López

Based on a photo by Citlalli López

Pinus caribeae, based on photos (of botanical specimens and living samples) by Ynocente Betancourt Figueras

From Left to Right: Based on photos by Ynocente Betancourt Figueras

Bursera aloexylon, drawn from a botanical specimen, Instituto de Ecología A.C. Herbarium, Xalapa, Mexico

Drawn from a sample

Based on a photo by Paul Hersch-Martínez

Based on a photo by Paul Hersch-Martínez

Hevea brasiliensis, drawn from a living sample, Empresa Brasileira de Pesquisa Agropecuária (EMBRAPA), Belém, Brazil

Based on a photo by Mariana Ciavatta Pantoja

Based on a photo by Mariana Ciavatta Pantoja

Based on a photo by Mario Pinedo Panduro

Redrawn from an illustration by Anabelle Maffioli (in ANAI Serie de Boletines Técnicos para el Agricultor, Boletín Técnico no. 3, El Pejibaye, 1986)

Based on a photo by Elaine Marshall

Based on a photo by Patricia Shanley

Platonia insignis, drawn from a living sample, Empresa Brasileira de Pesquisa Agropecuária (EMBRAPA), Belém, Brazil 
The Center for International Forestry Research (CIFOR) was established in 1993 as part of the Consultative Group on International Agricultural Research (CGIAR) in response to global concerns about the social, environmental and economic consequences of forest loss and degradation. CIFOR research produces knowledge and methods needed to improve the well-being of forest-dependent people and to help tropical countries manage their forests wisely for sustained benefits. This research is done in more than two dozen countries, in partnership with numerous partners. Since it was founded, CIFOR has also played a central role in influencing global and national forestry policies.

\section{Donors}

The Center for International Forestry Research (CIFOR) receives its major funding from governments, international development organizations, private foundations and regional organizations. In 2003, CIFOR received financial support from Australia, Belgium, Brazil, Canada, Carrefour, CARPE, China, Convention on Biological Diversity (CBD) Secretariat, Conservation International Foundation (CIF), European Commission, Finland, Food and Agriculture Organization of the United Nations (FAO), Ford Foundation, Forest Trends, France, German Agency for Technical Cooperation (GTZ), German Federal Ministry for Economic Cooperation and Development (BMZ), Indonesia, International Development Research Centre (IDRC), Inter-American Development Bank (IADB), International Fund for Agricultural Development (IFAD), Innovative Resource Management (IRM), International Tropical Timber Organization (ITTO), Japan, Korea, MacArthur Foundation, Netherlands, Norway, Overseas Development Institute (ODI), Peruvian Secretariat for International Cooperation ( $\mathrm{RSCl}$ ), Peruvian Institute for Natural Renewable Resources (INRENA), Philippines, PI Environmental Consulting, Sweden, Switzerland, The Overbrook Foundation, Technical Centre for Agricultural and Rural Co-operation (CTA), The Nature Conservancy (TNC), Tropical Forest Foundation, United States, United Kingdom, United Nations Environment Programme (UNEP), United Nations Educational Scientific and Cultural Organization (UNESCO), United Nations Forum on Forests (UNFF), United States Forest Service, Waseda University, World Bank, World Conservation Union (IUCN), World Resources Institute (WRI) and World Wide Fund for Nature (WWF). 
